\title{
A Roadmap to \\ Municipal Reform: Improving Life in Canadian Cities
}

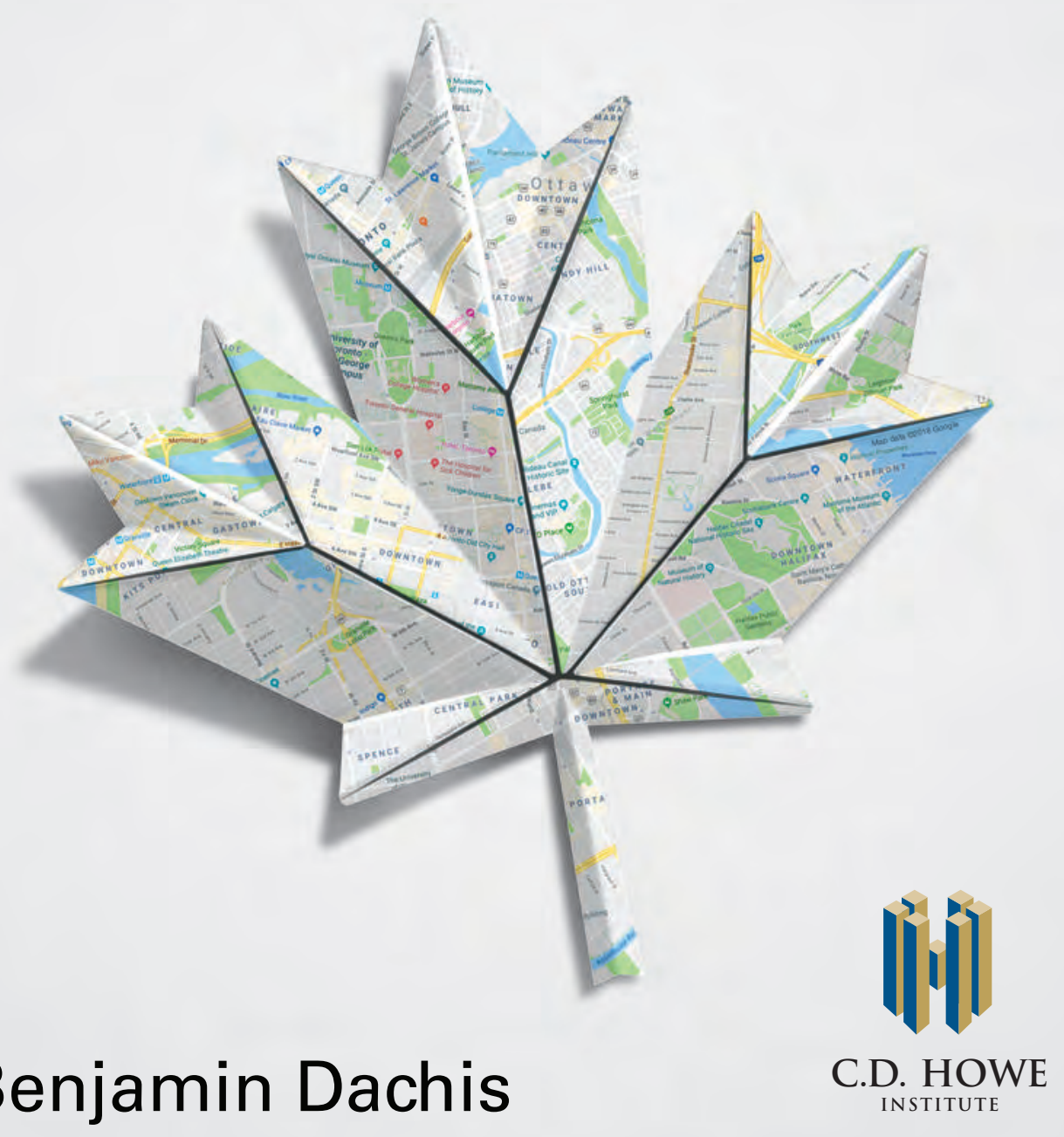




\section{THE C.D. HOWE INSTITUTE'S COMMITMENT TO QUALITY, INDEPENDENCE AND NONPARTISANSHIP}

The C.D. Howe Institute's reputation for quality, integrity and nonpartisanship is its chief asset.

Its books, Commentaries and E-Briefs undergo a rigorous two-stage review by internal staff, and by outside academics and independent experts. The Institute publishes only studies that meet its standards for analytical soundness, factual accuracy and policy relevance. It subjects its review and publication process to an annual audit by external experts.

As a registered Canadian charity, the C.D. Howe Institute accepts donations to further its mission from individuals, private and public organizations, and charitable foundations. It accepts no donation that stipulates a predetermined result or otherwise inhibits the independence of its staff and authors. The Institute requires that its authors disclose any actual or potential conflicts of interest of which they are aware. Institute staff members are subject to a strict conflict of interest policy.

C.D. Howe Institute staff and authors provide policy research and commentary on a non-exclusive basis. No Institute publication or statement will endorse any political party, elected official or candidate for elected office. The views expressed are those of the author(s). The Institute does not take corporate positions on policy matters.

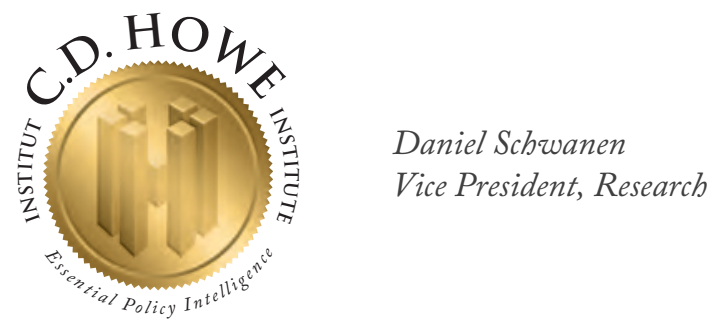




\title{
A Roadmap to Municipal Reform: Improving Life in Canadian Cities
}

Benjamin Dachis

\author{
Policy Study 46 \\ C.D. Howe Institute
}


C.D. Howe Institute publications are available from:

Renouf Publishing Co., Ltd.

22-1010 Polytek Road

Ottawa, Ontario K1J 9J1 Canada

Phone: (613) 745-2665

Toll Free: (866) 767-76766

Fax: (613) 745-7660

Shop secure online at: www.renoufbooks.com

Renouf Publishing Co., Ltd.

808 Commerce Park Drive

Ogdensburg, NY 13669-2208 USA

Phone: (888) 551-7470

Fax: (888) 551-7471

Shop secure online at: www.renoufbooks.com

Published by the C.D. Howe Institute

67 Yonge Street, Suite 300,

Toronto, Ontario M5E 1J8

October 2018

ISBN: 978-1-987983-78-4

(C) C.D. Howe Institute, Toronto.

Quotation with appropriate credit is permissible.

Edited and prepared for publication by Rosemary Shipton and James Fleming.

Cover design and artwork by Jake Leon; Map data (C2018 Google;

Figures and Tables by Yang Zhao.

Printed by THE AIIM GROUP,

Avant Imaging \& Information Management Inc.,

205 Industrial Parkway North,

Aurora, Ontario L4G 4C4 


\section{Contents}

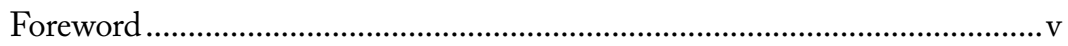

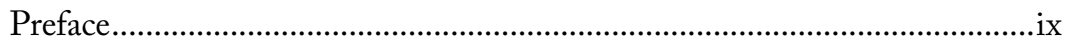

Chapter 1: The Need to Fix Canadian Municipal Policy.................................

\section{Part One: Municipal Budgets and Revenues}

Chapter 2: Busted Budgets:

Why Canadians Need to Rethink Municipal Budgets ..................................13

Chapter 3: Cities Aren't Poor:

They Don't Need Costly Grants or New Taxes ..............................................33

Chapter 4: Smart Ways to Fund Municipal Services.......................................59

\section{Part Two: Municipal Operations and Infrastructure}

Chapter 5: If You Can't Fight City Hall, Fix It ...........................................85

Chapter 6: How Cities Can Deliver Better Services at a Lower Cost........105

Chapter 7: The Cost of Traffic Congestion - and Its Cure ..........................129

Chapter 8: Getting More Buildings for Our Bucks

with Private Infrastructure

\section{Part Three: The Cost of Housing}

Chapter 9: The High Cost of High Home Prices .......................................181

Chapter 10: The Causes of the High Cost of Housing ...............................199

Chapter 11: How to Lower Costs for Homebuyers and Renters .................227

Epilogue: The New Canadian City...........................................................25

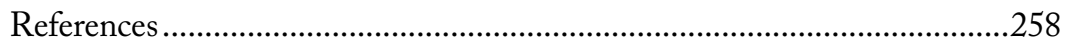





\section{Foreword}

To most Canadians on most days, the performance of their city, town or regional municipality matters more than that of any other level of government. More than four in five Canadians live in urban areas, a number that keeps rising. Housing, water and wastewater, transit and transportation infrastructure, safety - and, of course, municipal fees and property taxes - loom large in Canadians' lives. The opportunity to improve Canadians' lives by improving the performance of their local governments is commensurately great. That is the core motivation for this book.

The pages that follow explore challenges and policy reforms: the areas where Canada's municipalities could improve, and the changes to legislation and regulation at both the local and provincial level that could bring those improvements about. Benjamin Dachis, a former Associate Director, Research, at the Institute, both brings together, and advances, years of penetrating, high-quality work on municipal issues - much of it published by the C.D. Howe Institute - from many of the top scholars in the field. Readers will find important insights on housing, choosing and financing local and regional infrastructure, municipal and regional governance, and budgeting. 
Dachis begins by illustrating how municipal and urban policies affect the life of an ordinary resident going about her day. He then dives into the core of municipal decision-making: the budget process. Dachis explains how current practices impede good investment in, and management of, municipal assets, and how improvements in budgeting could foster more and better-maintained infrastructure. He then examines various municipal services, with recommendations for improving their delivery and financing them more fairly. In the third major section of the book, Dachis tackles housing availability and affordability, showing how changes to infrastructure financing, land-use, and other regulations could help more Canadians find shelter that matches their needs and their budgets.

We at the C.D. Howe Institute are delighted to present Dachis's analysis and recommendations. Because municipal governments across Canada are so diverse - in size, location, industrial profile, the environments their provinces create for them, and much else - Canadians looking for ideas to improve their own local government face obstacles drawing lessons from elsewhere. And discussions about "the urban agenda" suffer not just from legitimate differences about what level of services and taxation are appropriate, but from confusion about funding, conflict and overlap among layers of government, lack of transparency, and grandstanding by people far removed from the on-the-ground action that determines how well cities serve their citizens. Dachis's insights and practical ideas will resonate with readers - and, we hope, with policymakers - in cities and towns across the country.

In addition to Benjamin Dachis himself, I thank the many other people who contributed to this book - the scholars who have worked in the field, the many experts who reviewed earlier drafts of this manuscript, and the C.D. Howe Institute's editing and production team. Although the views expressed here are those of the author, and not necessarily those of the Institute's staff, members 
or board of directors, we publish this book with confidence that it will be of interest, and of practical use, to elected officials and other decision-makers, and to everyone interested in improving the contribution of Canada's local governments to Canadians' quality of life.

William B.P. Robson

President and Chief Executive Officer 



\section{Preface}

This book is a decade in the making. It rests in large part on the work the C.D. Howe Institute has published in the last ten years, work I have updated and complemented here to give a full picture of the issues that affect the residents of Canadian cities and which fall under the purview of municipal governments. Indeed, while many sections of the book are summaries of the text from various essays, op-eds, and Intelligence Memos I have written or co-written, and a few sections in chapter 8 are taken (with permission) from the work of a collaborator, a number of chapters and sections in this book contain ideas I had not worked on until I started this project.

I am able to write on Canadian municipal policy only by standing on the shoulders of the giants who preceded me in this field: Canadian urban economists such as David Amborski, Richard Bird, Robert Bish, Frank Clayton, Harry Kitchen, Robin Lindsey, Almos Tassonyi, and especially Enid Slack (who towers over all areas of Canadian municipal finance). Slack co-founded, along with the equally prodigious Alan Broadbent, the Institute on Municipal Finance and Governance, which has produced many of the essays and sponsored events that have given me much valuable information. Other scholars who have influenced me are Ed Glaeser from 
Harvard University and several of my urban economics professors at the London School of Economics: Paul Cheshire, Steve Gibbons, Christian Hilber, and Henry Overman. John Munro and David Nowlan at the University of Toronto inspired me to keep digging into the big economics questions, and I miss them both immensely.

I also owe many thanks to my co-authors and collaborators in researching municipal and public finance issues for the C.D. Howe Institute. My role in those projects has ranged from journal editor to research assistant to deadline enforcer. I learnt much from Marcel Boyer, Mike Campolieti, Bev Dahlby, Don Dewees, Gilles Duranton, Adam Found, Jonathan Hall, Robert Hebdon, Aaron Moore, Steve Robins, Bill Robson (president of the C.D. Howe Institute), Zac Spicer, Vincent Thivierge, Peter Tomlinson, Michael Trebilcock, Matthew Turner, and many more whom I have worked with over the last decade. Although references to their work on Canadian municipal policy will appear throughout this book, any errors are entirely my responsibility. Many reviewers provided extraordinarily useful comments on various chapters of the book, and I owe them a huge debt. In addition to anonymous reviewers, they included Ronald D. Kneebone, Kenneth James McKenzie, Enid Slack, Zachary Spicer, Almos Tassonyi, Peter Tomlinson and Margarita Wilkins. Daniel Schwanen and Bill Robson gave detailed comments on my first draft, for which I am most grateful. Rosemary Shipton did an expert copy-editing job on the final draft. James Fleming skillfully top-edited, Jake Leon gorgeously prepared, and Yang Zhao finished the final document. Any remaining errors are, of course, my own.

I would like to thank Duncan Munn, chief operating officer and senior vice president of the C.D. Howe Institute, and Daniel Schwanen, vice president of research, for giving me a leave-of-absence from the office for a few months to work on this book and for publishing the book after I departed the Institute. All substantive work 
in the book was completed before I departed. Many other colleagues - Phillippe Bergevin, Colin Busby, Jeremy Kronick, Alexandre Laurin, Finn Poschmann, Bill Robson, and Daniel Schwanen - have given me valuable feedback on the studies that underlie my research. Jacob Kim provided enormously valuable research assistance for the book and created most of the comprehensive municipal financial database used throughout.

Finally, my deepest thanks go to my wife, Sam, who spent much time alone as I worked on this text. During our travels it became a third passenger, constantly occupying my attention. She is my muse, my copy editor for the first draft, and my partner in every part of life. This book is for her. 


\section{Chapter 1}

\section{The Need to Fix Canadian Municipal Policy}

It's morning in Canada's big cities, and nearly everything residents do will be affected in some way by local government. The typical Canadian urbanite, like most other Canadians, starts the day by turning on the light. The power in their homes was probably delivered by companies owned by their municipal governments. Next they go to the shower. The water most likely arrives via water-treatment and distribution systems owned by their local governments. It's the same with the wastewater, which makes its way to treatment plants. A good start to the day. So far.

In one home, a small businesswoman is leaving for work downtown. Perhaps today she'll take transit, beginning with a bus ride to the nearest railway or subway station. She may need to pay again to enter the station, if the train line is operated by a different level of government. If the transit operator hasn't installed automatic payment technology, she'll have to produce the exact fare or overpay. Annoyed, she heads to the platform.

It's rush hour and the platform is packed. When a train finally pulls into the station, it's so crowded that no one can get on board. 
Our businesswoman manages to squeeze onto the next train, jostling with another passenger to be the last sardine in the car. She frets about the wasted time as the train crawls along. Will she miss her morning meeting? Can her business survive if customers can't make it downtown? Will she get good employees willing to suffer through chaos every day?

Once at her shop, she checks the mail and spots an envelope from the city. It's the property tax bill for her business. How can it be so high? The business has the same assessed value as her home, but the bill is multiple times more than her residential property tax bill. She's been looking for a home closer to her work, and when she's settled, she'll complain to her new local councillor.

Later in the day, she gets a call from her real-estate broker to say that her offer on a modest home has been accepted. Real-estate prices have been skyrocketing, and rental options have been in short supply ever since the provincial government put in strict rent controls. Her dream has always been a new single-family home with a backyard for her growing family, but after seeing the prices - which keep rising because of limited land availability and the fees put on developers - she's lowered her ambitions to a condominium. The broker lays out the total cost to complete the deal. The land transfer tax has just been increased by the provincial and municipal governments, and the broker reminds her that she must pay it upfront - it isn't something she can lump in with her mortgage. She'll need to scrape together an even larger down payment than she thought. Discouraged, she decides to drive home in a rental car owned by a car-sharing service rather than repeat the morning commute.

As she approaches the highway, she sees a long line of cars waiting to access it. She fights her way onto the highway and spots a free-flowing lane on the far left-hand side. The carpool lane is mostly empty and fast moving, but she's the only person in the car, so cannot use it. She inches along in one of the other lanes, knowing that, if 
she's late, she'll have to pay a fine at her daughter's daycare. As soon as she can she exits the municipally owned highway and drives to the private highway a few kilometres away. Sure, she will pay a toll, but there won't be much other traffic.

After picking up her daughter, she finally arrives home. But there's nowhere to park, and she circles the block a few times before she finds a spot. It's garbage day, and she and her daughter weave through bins thrown everywhere as they walk toward the house. Still, better than this time last year, she thinks, when municipal workers went on strike and there wasn't any garbage pickup. The whole city stank. When she arrives home, she finds that her recycling was missed. She'll need to call 311 to have the city take it away.

At least the mail arrived, bringing her municipal electricity and water bills. She doesn't have the heart to look at them, knowing how much they have increased. Collapsing onto the couch at home, she wonders how she can make her life easier. But before she can collect her thoughts, it's time to prepare dinner.

Sound familiar? If you live in any of Canada's larger metropolitan areas, much - perhaps most - of this story will be part of your experience. And similar issues arise in smaller Canadian cities. Congestion, for example, may not be a big problem for a rural municipality, but the same issues relating to budgets, taxes, money for infrastructure, and other areas apply to towns of a thousand people or cities with millions of residents. Municipal governments touch nearly every part of our daily lives: when municipal taxes are high, we have whopping tax bills; when municipal services break down, they affect us; when cities restrict housing development, we see rapidly spiralling house prices. Whether you relate to every part of this story or just a few items, there is something that your local government can do to improve your life. 


\section{Fixing Municipal Government}

This book covers three big themes in how cities can do better. Part One looks at the way cities finance themselves and, through their budget plans, lay out the broad directions for their policies and administration. Part Two covers how cities spend the money they collect, both on day-to-day operations and on infrastructure. Part Three looks specifically at housing policies - at the way municipal governments are making homes more expensive to own and rent, and how they can fix that problem. ${ }^{1}$

\section{Fixing Municipal Finances}

The common misperception that cities are broke stems from the way they set their budgets. Cities do not need additional tax powers beyond their traditional tax base of residential property taxes and user fees. The accounting system that governments use in their finances is linked to the language in which it is expressed - in much the same way as learning a new language changes the way we think. Chapter 2 will show how, if we use the same financial accounting language for municipalities as the federal and provincial governments use, our understanding of municipal finances will change dramatically. Simply by adopting this more accurate language, a major misconception will have been removed.

This misperception of municipal finance leads cities to request more transfers and more tax powers, but both adjustments are unnecessary and come with high economic costs. Cities should stick to the financing tools that work best for voters to keep their municipal governments accountable: user fees and residential property taxes.

1 Throughout the book, I will use the terms "city" and "municipality" interchangeably. These terms refer to any incorporated government. I refer to broader areas that cover multiple municipal governments in general terms such as urban areas or, more specifically, as the Greater Toronto Area or as Census Metropolitan Areas as defined by Statistics Canada. 


\section{Getting Better Municipal Services}

Most Canadians would be forgiven for not knowing where their councillor stands on how to spend tax dollars. In the absence of a full-fledged political party system, neither do other council members - and that is a problem. To fix it, all governments should consider a move to a municipal party system. Party affiliation sends a strong signal to voters and helps councils to make better spending decisions.

The core driver of municipal expenses is labour costs - they are already high and are increasing quickly. For police and firefighters, cities are at the mercy of the way arbitrators settle disputes. Cities should look to more competitive contracting (which is different from privatization) for many other services, such as transit and waste collection. A competitive bidding process derives cost savings by awarding contracts to those - whether private companies or in-house staff - who can demonstrate that they can provide services at the lowest cost. Numerous case studies throughout the book present examples of successful and unsuccessful policies, both in Canada and abroad. Contracting services on a competitive basis can dramatically reduce costs while simultaneously increasing service reliability and quality, as seen in Toronto's waste collection services (see figure 1.1)

Canadian cities across the country continue to make the case that they face an "infrastructure deficit." Roads are congested. Trains and buses are crammed. So, cities say we need to build more - preferably paid for with grants from other levels of government. But why do we have this congestion and no money to pay for new infrastructure? It's simple - we do not put a price on roads. If cities put a proper price on municipal infrastructure, they would have the money available to reinvest. They would also have private infrastructure investors knocking on the door to finance infrastructure and would not have to rely as much on taxpayer dollars. The current state of infrastructure across Canada is the result of choices that cities make because of incorrect pricing and taking on investment 


\section{Figure 1.1: How Contracting Has Reduced Waste Collection Costs in Toronto}

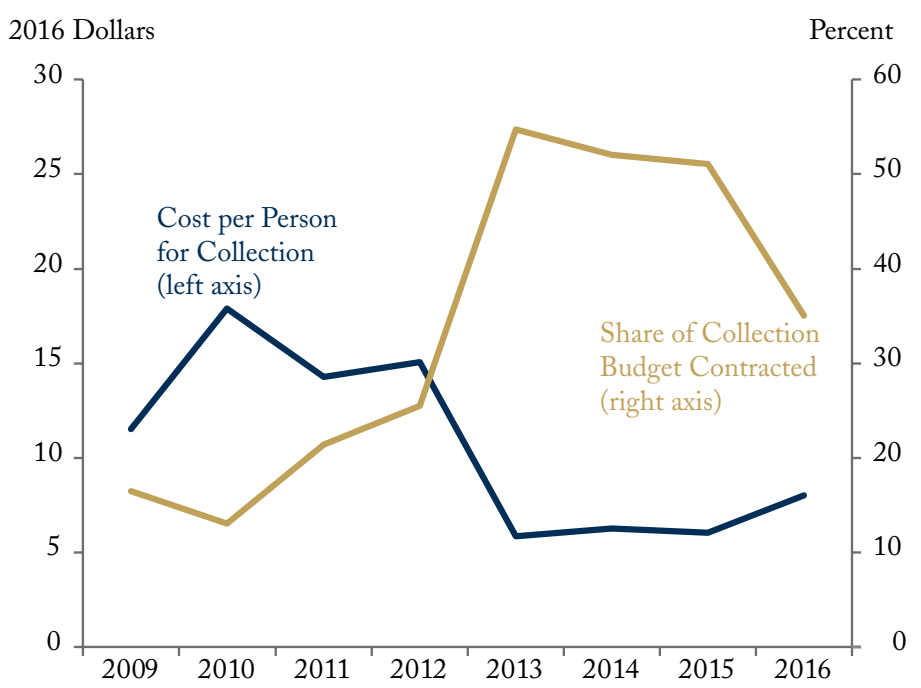

Source: Author's calculations from Ontario Financial Information Return.

themselves. If cities worked with private partners willing to charge a price, Canadians would have more of the infrastructure they want.

\section{The Costs and Causes of High Housing Prices}

High house prices have many consequences. They leave people to languish where they are less productive than they could be simply because they cannot afford to move to cities with high housing costs. Families are trapped in homes that do not fit their needs and, in some urban areas, poor people end up homeless.

Aside from Toronto and Vancouver, however, house prices in Canada have not historically gotten out of control (Figure 1.2). Even during its economic boom, house prices in Calgary barely budged. In Montreal and Ottawa, two cities that have seen recent solid economic growth, house prices were flat from 2007 through 2016. In Part 


\section{Figure 1.2: Some Cities See Rising Costs of Housing, and Others Stay More Affordable}

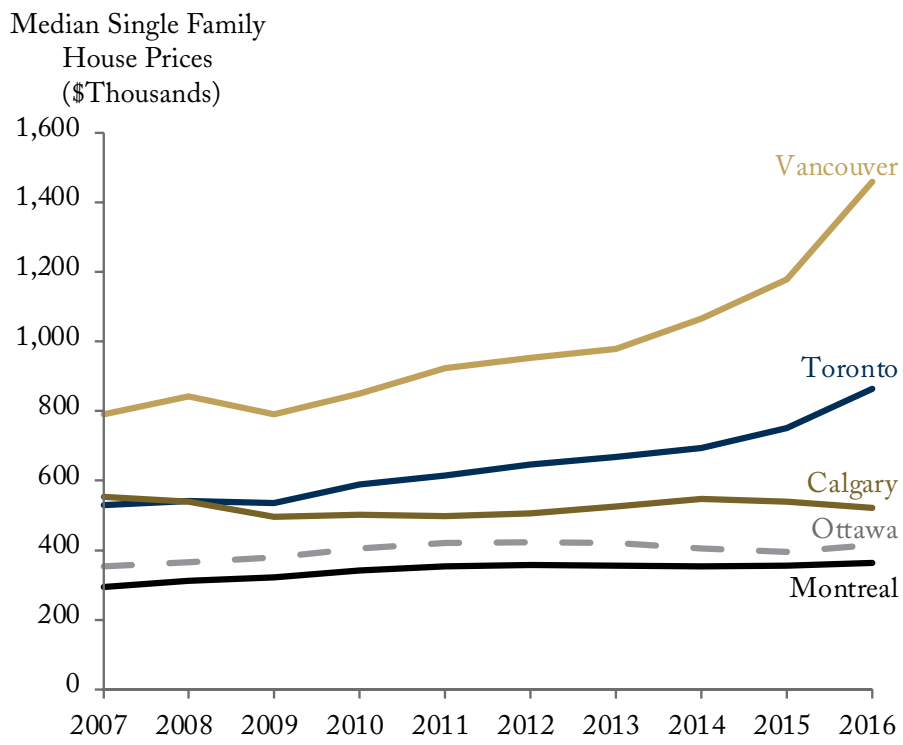

Source: Author's calculations from Brookfield Real Property Solutions (RPS).

Three we will look at the local-policy-driven causes of high house prices in Toronto and Vancouver and what to do about it.

\section{What Makes This Book Unique}

Many books and articles have been written about Canadian municipal policy. In this book I will attempt to pull together an accessible summary of the latest thinking on urban economics and how these new ideas apply to Canadian urban and municipal policy. In some aspects my approach is different from most of the others on this subject.

First, I look at Canadian municipal policy through the lens of economics rather than political science, urban planning, and other disciplines. This approach may lead to a different diagnosis of the same problems and to different prescriptions of the best way 
to fix them. Second, I have used different data. Many people think that data on municipal government are hard to come by, but that is not true. Good municipal data are just hard to work with, and I have spent many years working with them. Each of the four largest provinces in Canada has a massive database of detailed financial data of every municipal government in the province. From the biggest metropolis to the tiniest hamlet, we now know a lot about the finances of most local governments. Ontario, for example, through the Financial Information Return, has some of the best city-by-city data in the world.

Third, most analyses of government finance come from a top-down approach using Statistics Canada data. Though I use that method occasionally, for the most part I take a bottom-up approach that uses city-level data in Ontario, Quebec, British Columbia, and Alberta. Most of the results in my case studies are equally applicable to municipalities across Canada, whether in Saskatchewan, Manitoba, or Atlantic Canada. Moreover, most of the data can be broken out city by city, region by region, and sometimes house by house.

\section{Delving Deeper into Municipal Finances}

We can use this data to see which Canadian cities are the best - and the worst - on a number of financial criteria. Many municipal governments are spending an enormous amount per person. We will uncover what makes rural Alberta municipalities such as Wood Buffalo, the oil sands hub of Fort McMurray, collect a large tax revenue even though it has few residents. I will also investigate why Ontario cities deliver many social services on behalf of the province.

In addition, we will delve deeper into the net financial worth of Canadian cities. Many fret about the debt that cities take on, particularly in Toronto and Montreal, where it is high. But cities have accumulated huge assets and, with the possible exception of Quebec 
cities, that means massive positive net worth. Both in this book and online readers will be able to see what parts of Canada are most reliant on municipal property taxes. Quebec cities stand out for having a particularly large share of their expenses covered by property taxes. Is that the right approach?

\section{Making Life Better in Canada's Cities}

Life is good in Canada for the vast majority of its inhabitants. Despite problems with transit, traffic, and trash collection, to name a few, we are better off than people in most other countries. Our municipal policymakers are, almost universally, well intentioned and motivated to improve life for their residents. However, they - and we - can always do better. They need answers to hard technical questions we will cover in this book as well as public support for politically unpopular changes they know are necessary. Other cities around the world are looking to do better, and Canadian cities need to keep up.

This book can be read either cover to cover as a roadmap to comprehensive reform of municipal government or selectively by chapter. It is intended for councillors, provincial and municipal civil servants, the media, and citizens - all those who want real solutions to real problems.

Let's begin with sensible reforms for all municipal tax and spending decisions: the municipal budget. 



\section{PART ONE}

Municipal Budgets and Revenues 



\title{
Chapter 2
}

\author{
Busted Budgets: Why Canadians \\ Need to Rethink Municipal Budgets
}

Each year municipal governments across the country struggle to balance their budgets, yet the financial statements reveal that Canadian cities are running surpluses nearly every single year. Ever since cities began in 2009 to report their finances on a modern accounting standard, the 28 largest municipal governments in Canada have run cumulative surpluses - of around $\$ 60$ billion between 2009 and 2016. In addition to these annual surpluses, cities have amassed enormous positive net wealth in infrastructure assets - enough to make the debt-ridden provincial governments green with envy.

Most readers will be surprised to hear of this surplus: they have the impression that cities are just scraping by as they beg for more grants and increased taxing powers to fund municipal services. In fact it is the way we debate municipal budgets that distorts our view of municipal finances, making it harder than it should be to decide how to finance local governments. 
The annual budget is only half the story, however. A budget is but a plan; what a city actually spends is what matters. Moreover, the way a city presents its end-of-year results is very different from the way it sets out financial information in its budget.

Today, most municipal budgets follow a cash-based budget: they consider only money in and money out. End-of-year financial statements are on an accrual basis: they show expenses when services are rendered, not necessarily when cities write cheques for their expenses. Obviously, using two different documents that tell different stories about municipal finances is a poor route to fiscal accountability. ${ }^{2}$

The way cities present their budgets influences the decision making for nearly every aspect of municipal policy we examine in this book. In turn, once we understand the accrual-based accounting system, we will never look at municipal finances the same way again.

\section{Municipal Budgets and Financial Statements}

Canadian cities produce two major documents in their annual fiscal cycles: budgets and financial reports. Because these two documents rely on different accounting systems, they tell two completely different stories about municipal finances.

Budgets contain municipalities' fiscal plans at the start of the fiscal year. They take months to prepare and are the principal opportunity for citizens, their elected representatives, and the media to consider and provide input on municipal priorities. In most cases, cities present a capital budget for long-term investments, and then they produce an annual operating budget for expenses that occur

2 This chapter draws heavily on, and quotes from, a series of projects I have done at the C.D. Howe Institute, mainly with Bill Robson. See Dachis, Robson, and Omran (2017); Dachis, Robson, and Tsao (2016); Dachis and Robson (2011, 2014, and 2015). 
annually. For most cities, the operating budget is also subject to a provincial requirement that it be balanced. In general, cities present these budgets based on their cash flow in any given year - such as property taxes, debt finance, and grants - relative to their operating and capital expenses. Not surprisingly, this system is called accounting on a cash basis. ${ }^{3}$

Audited financial reports show municipalities' fiscal reality at the end of the fiscal year. Under standards set by the Public Sector Accounting Board (PSAB), which govern Canadian government accounting practices, all cities must present their financial statements on a standardized accrual accounting basis. This common accounting basis provides largely comparable measures of municipal finances. External auditors provide additional comfort to taxpayers, the media, and councillors of the soundness of the books. In 2009, cities were required by PSAB to report the value of municipal assets and to adopt accrual accounting in their financial statements - something they had not done comprehensively in the past.

\section{How Does Municipal Accounting Work?}

There is an ongoing and energetic debate regarding the best way to represent economic reality in financial reports. Accrual accounting - now used at all stages by most senior-level governments and in municipal end-of-year financial statements, but not comprehensively in municipal budgets - holds that financial reports should anticipate, or report, revenues and expenditures during the period when the particular service occurs. For example, in the purchase of a longlived asset such as a building, it does not make sense to record the entire construction cost as an expense in the year the cash is laid out. In accrual accounting, the value of the building is recorded as an asset and amortized as an expense. The building is gradually written

3 Cities also often refer to it as a partial or semi-accrual basis simply because they do use accrual methods for matters such as accounts receivable. These additions are inconsequential deviations from cash budgets. 
off as it delivers its services, thereby bringing the cost of the building into annual spending over several years. This amortization is the core difference between accrual and cash accounting.

Let us see how these two different accounting practices would work for Metropolis, a hypothetical city, that has three kinds of expenses: $\$ 100$ in annual operating expenses such as office supplies and salaries; a one-time $\$ 100$ subway infrastructure project built in a particular year that will benefit users over the following five years before it needs to be replaced; and $\$ 50$ in pension and healthcare promises it agreed to with current employees that it will begin to pay in five years. Metropolis finances all annual operating costs with $\$ 100$ from property taxes and receives $\$ 100$ in a one-time, higher-level government transfer, which it decides to use to finance the subway. Figure 2.1 shows Metropolis's budget on a cash basis and on an accrual basis. For simplicity, this example covers only five years. In real life, when looking at infrastructure or pension costs, the differences between the time when bills would become due under different accounting methods could take generations to appear.

Under cash accounting, Metropolis easily runs a balanced budget in the first four years with revenues from annual property taxes and transfers. It used the grant from the higher-level government to pay for the subway. Taxpayers in year 1 - who ultimately fund the higher government transfers - financed the whole cost of the subway that benefits taxpayers over the next five years. However, in year 5, when pension obligations come due, Metropolis must find $\$ 50$ that its cash budgets in previous years missed. Taxpayers in year 5 will pay for the benefits that taxpayers in years 1 through 4 received from the work of municipal employees. As we can see from this example, cash accounting obscures the costs and benefits from longterm commitments and the comparison of annual costs and benefits. 


\section{Figure 2.1 Metropolis's Budget: Cash versus Accrual}

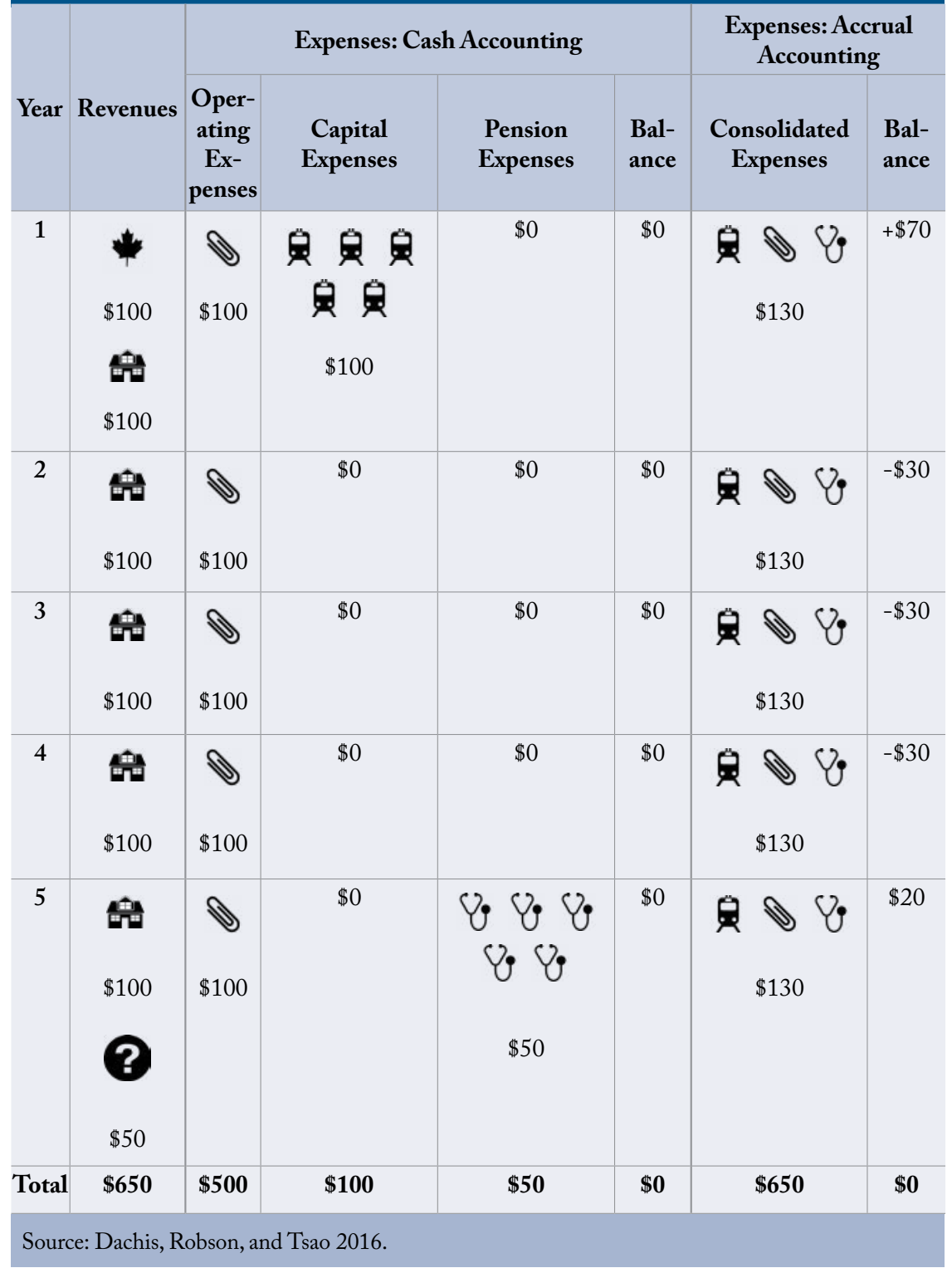


If Metropolis budgeted on an accrual basis, its consolidated expenses would show the annual share of the combined operating, capital, and pension cost to taxpayers in the year the service occurred. Its accrual budget would include the same annual operating cost as the cash budget, plus one-fifth of the infrastructure outlays in year one and one-fifth of the pension outlays due in year five. The accrual method highlights the intergenerational inequity - the surpluses of $\$ 70$ in year 1 and $\$ 20$ in year 5 , and the deficits in years 2 through 4 - created by cash accounting that relies on taxpayers in year 1 to finance infrastructure, and taxpayers in year 5 to finance pensions and health benefits. Accrual budgeting might lead Metropolis to finance the subway from user charges or property taxes over the life of the assets - rather than an upfront grant - and to pre-fund its pension obligations. If it did, its budget, on an accrual basis, would be balanced each year. That would mean that the generation that benefits from the service the city provides - labour from workers, travel on the subway - is the same one that pays for it.

Accrual accounting as currently practised is not perfect. Outside capital assets, a notable gap in public-sector accounting - a deviation from the accrual principles that apply in the private sector - is delayed recognition (and often inappropriately high discounting) of the cost of employee benefits earned but not yet paid, especially pension obligations. Governments in Canada - and elsewhere - tend to discount the cost of their pension liabilities, using assumed rates of return on assets that are higher than yields on retirement-grade securities (Robson and Laurin 2016, 2018). Still, having at least some recognition of retirement costs is better than the alternative of entirely overlooking them, as cash accounting does.

\section{Distortions in Municipal Finances}

If we move from this hypothetical example to the actual experience of Canadian municipalities, we see how accrual accounting changes our perception of municipal fiscal health. 


\section{Recasting Municipal Finances}

When we examine the end-of-year financial statements for 28 of Canada's municipalities from 2008 through 2016, we find that these governments ran an aggregate cumulative surplus of $\$ 60$ billion (table 2.1). ${ }^{4}$ The 2016 surplus, nearly $\$ 8$ billion, was 11 percent of their revenues that year. The municipalities with the largest surpluses as a share of revenues in 2016 - Calgary, Saskatoon, Surrey, Edmonton, Vaughan, and the Ontario regional municipalities of Halton, Waterloo, and York - had surpluses exceeding 20 percent of their revenues. A robust balance sheet is not objectionable in principle; the trouble is that hardly anyone thinks about their city's finances this way because the budgets on a cash basis look balanced. If decision-makers had been aware of these surpluses, many of their decisions about tax rates, development charges, and infrastructure investments might have been different.

What do these surpluses mean? They come about because cities are collecting more revenue from today's generation of taxpayers than the taxpayers are getting back in services. Rather, we should think about the amortization line in each city's financial statements as the value the current year's taxpayers are getting from every dollar of capital the city has invested. When the accrual budget is in surplus, current taxpayers pay more than the value of the services they are getting back. If there is a deficit, they are paying less than the value of services they are getting. In 2016, only in one city out of Canada's largest 28 did taxpayers get more back in services than they paid: Quebec City.

4 Among the 28 are the 20 largest municipalities by population. I also include the six most populous regional municipalities in Ontario as well as Sudbury and Windsor. 
Table 2.1: Surpluses of Canadian Municipalities Relative to Revenues, 2016

\begin{tabular}{|c|c|c|c|}
\hline \multirow[b]{2}{*}{ Municipality } & \multicolumn{2}{|c|}{2016 surplus } & \multirow{2}{*}{$\begin{array}{c}\text { 2008-2016 surplus } \\
\text { Cumulative } \\
\text { (\$millions) }\end{array}$} \\
\hline & $\begin{array}{c}\text { As share of } 2016 \\
\text { revenues } \\
\text { (percent) }\end{array}$ & $\begin{array}{c}\text { Total } \\
\text { (\$millions) }\end{array}$ & \\
\hline Toronto & 10 & 1,248 & 7,724 \\
\hline Montreal & 6 & 403 & 4,281 \\
\hline Calgary & 25 & 1,237 & 8,875 \\
\hline Ottawa & 13 & 503 & 3,529 \\
\hline Edmonton & 23 & 836 & 5,528 \\
\hline Peel & 15 & 388 & 2,812 \\
\hline York & 22 & 509 & 3,715 \\
\hline Hamilton & 10 & 181 & 1,488 \\
\hline Winnipeg & 9 & 162 & 1,833 \\
\hline Vancouver & 18 & 315 & 1,523 \\
\hline Quebec City & -3 & (37) & 358 \\
\hline Durham & 16 & 253 & 1,391 \\
\hline London & 14 & 167 & 1,342 \\
\hline Waterloo & 23 & 282 & 965 \\
\hline Halifax & 6 & 63 & 688 \\
\hline Laval & 13 & 130 & 1,044 \\
\hline Niagara & 8 & 72 & 540 \\
\hline Mississauga & 7 & 59 & 754 \\
\hline Halton & 34 & 398 & 2,307 \\
\hline Windsor & 4 & 33 & 492 \\
\hline Brampton & 6 & 46 & 1,203 \\
\hline Surrey & 24 & 216 & 1,671 \\
\hline Saskatoon & 22 & 198 & 1,840 \\
\hline Longueuil & 2 & 16 & 225 \\
\hline Gatineau & 12 & 88 & 832 \\
\hline Sudbury & 3 & 17 & 324 \\
\hline Vaughan & 23 & 128 & 1,384 \\
\hline Markham & 15 & 52 & 1,010 \\
\hline Total & 11 & 7,963 & 59,928 \\
\hline
\end{tabular}




\section{Figure 2.2: Provincial and Municipal Net Worth, 2008-16}

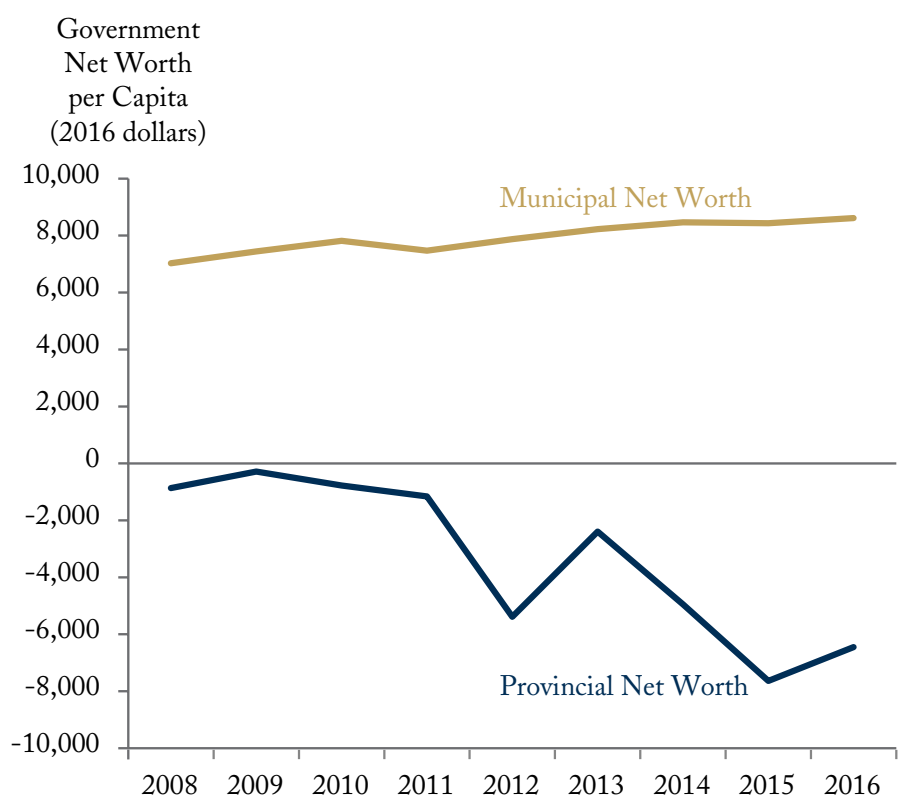

Source: Author's calculations from Cansim tables 385-0034 and 385-0037.

\section{Comparing Municipal Fiscal Health to Provinces}

The story of municipal governments collecting more from taxpayers than they give back in services is not limited to the largest cities. In 2008, Statistics Canada started to collect information on the net worth of Canadian governments - a concept that is valid only in a world with accrual accounting. In the years since, municipal governments across the country have seen their net worth increase dramatically. Canada's cities had a positive net worth of over $\$ 300$ billion in 2016, up from just over $\$ 208$ billion in 2008 . Per person, Canada's cities had a positive net worth in 2016 of $\$ 8,600$ (figure 2.2).

In contrast, Canadian provinces have spent much of the last decade falling deeper and deeper into debt. As a whole, they are looking at over $\$ 230$ billion in total negative worth in 2016, after 


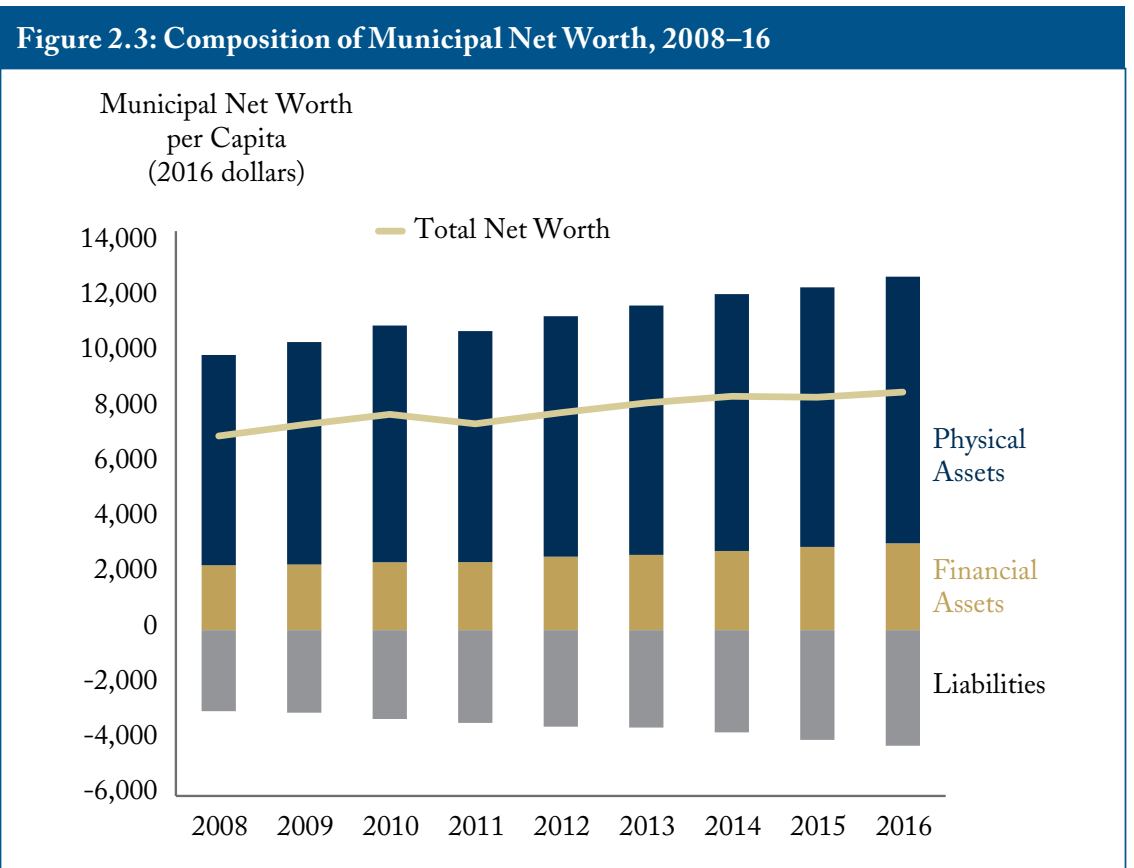

Source: Author's calculations from Cansim table 385-0037.

having nearly equally valuable assets and debts in 2009. Per person, the negative provincial net worth was approximately $\$ 6,500$ per person in 2016.

What does this net worth mean? Cities still have debt - and the total debt they are taking on has been increasing slowly (figure 2.3). But the value of assets that cities are investing in is far more than the debt cities have been incurring every single year since 2008. These municipal assets give cities considerable flexibility in selling those that are not a core part of municipal services (such as electricity infrastructure) to finance ones that are (such as public transit) (see chapter 8).

The data from Statistics Canada are also available at a provincial level. Ontario and Quebec - Canada's two largest provinces 
- show very different patterns through 2016 (figure 2.4). Subnational government total net worth taken as whole is about the same in both provinces, but the share of debts and assets for each government is very different. Cities in Ontario have a high net worth: over $\$ 10,000$ per capita. The province, however, has a negative net worth of around $\$ 15,000$ per person. The fiscal health of provincial and municipal governments in Quebec is somewhat more even. Cities in Quebec have a net worth of around $\$ 2,000$ per person, while the province of Quebec has a negative net worth of around $\$ 10,000$ per person.

This fiscal imbalance largely goes unreported. If more people looked at the net worth of Canadian cities relative to provinces, it would change the relative dynamic of municipal-provincial fiscal relations, especially in Ontario. While the province of Ontario is deep in debt and cities continue to amass assets, the province goes on sending large and growing transfers to cities. Between 2009 and 2016, annual transfers from the province to Ontario cities grew by around $\$ 1$ billion, reaching more than $\$ 8$ billion (see chapter 3 ).

Now that we have the data from accrual-based financial statements of Canadian cities, we can see that these transfers amount to the wealthy (cities) taking from the impoverished (the provinces). Indeed, in Ontario the fiscal imbalance is worsening. For example, the province recently committed to increasing its provincial fuel-tax grants to cities in place of allowing the City of Toronto to introduce a road toll (see chapter 7).

\section{Why Accounting Practices Matter}

If you own a house, chances are you bought it using a mortgage with monthly payments. If you have a young and growing family, it makes sense to pay off your house as you use it. If you waited until you had accumulated the full payment, your children would likely have moved out by then and you would not need the house anymore. 


\section{Figure 2.4: Quebec and Ontario Provincial and Municipal Net Worth, 2008-16}

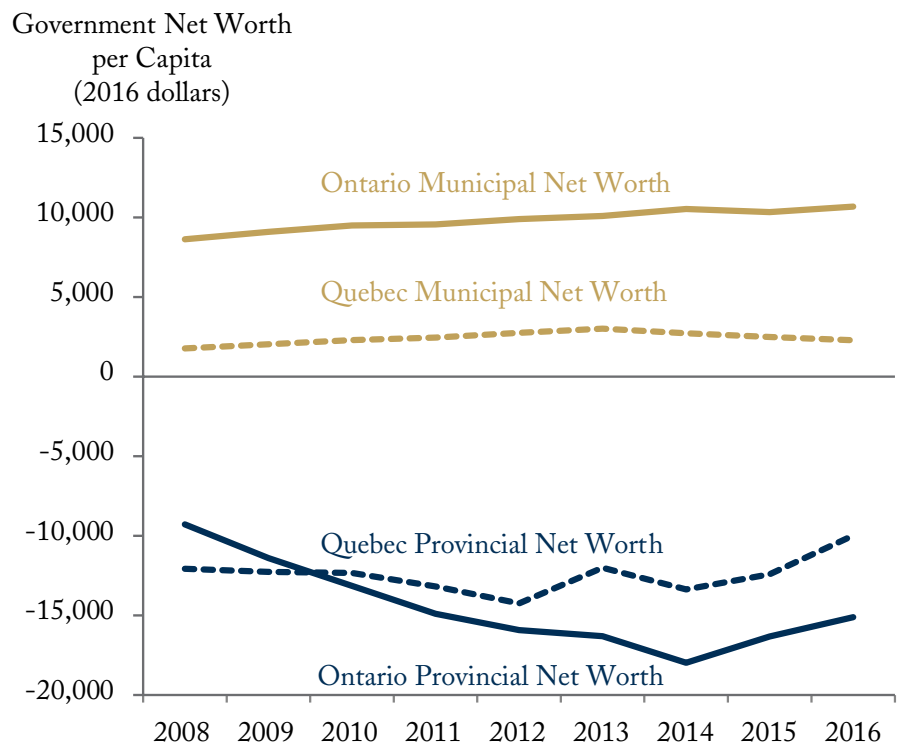

Source: Author's calculations from Cansim tables 385-0034 and 385-0037.

Yet many cities are financing their infrastructure needs in terms of cash budgeting. They present councillors with capital budgets that show outlays on such assets as in-year expenses rather than amortizing them as they deliver their services (as accrual accounting does). This method leads municipalities to delay or reject some capital projects they would otherwise approve. It also encourages them to finance the projects they do approve by raising revenues up front, rather than by borrowing and servicing the debt over the period that the project yields its benefits.

The development charges that municipalities impose on home builders are a key financing mechanism for municipal capital assets. In many municipalities, the largest single element in these development charges is to provide the infrastructure for drinking 
water, sewerage, and wastewater construction. Between 2010 and 2016, Ontario municipalities collected $\$ 11.1$ billion in development charges, $\$ 4.3$ billion of which was dedicated to water infrastructure (see chapter 11). These charges might make sense if they followed the accrual accounting principles and allocated costs across people and over time in proportion to the enjoyment of the related benefits (see Bird, Slack, and Tassonyi 2012). Instead, the prevailing cash-based budgeting biases municipalities toward levying charges up front forcing new homebuyers to finance new municipal infrastructure that benefits other users far into the future.

Development charges range from about $\$ 80,000$ for a single-family house in a new development area in some Greater Toronto Area municipalities to $\$ 30,000$ in Surrey and $\$ 20,000$ in Calgary. Quebec cities, in contrast, are prohibited by provincial law from levying development charges - an explanation, perhaps, why they haven't accumulated large positive net worth. To the extent these fees are higher because cash budgeting encourages up-front financing, they make new homes less affordable (see chapter 10).

\section{Differences Accrual-Based Budgets Would Make}

Accrual accounting would inform municipal councillors and taxpayers about the way decisions affect the net worth of their city. It is most helpful when cities consider the financing of long-lived infrastructure assets, or how future obligations, such as the pension entitlements of municipal employees or landfill decommissioning and other environmental liabilities, affect their net worth.

As we saw in table 2.1, taxpayers in Canada's 28 largest cities in 2016 paid nearly $\$ 8$ billion more to cities than they got back in services. Ultimately, municipalities may want to continue paying for capital assets up front, but accrual budgets would clarify for both councillors and taxpayers the intergenerational impact of the funding 
choice they are making. The result might well be more demands on cities.

\section{Matching Those Who Benefit with Those Who Pay for Government}

Services

Cities are avoiding debt by foisting it on homeowners. As the price of housing rises, residents should ask whether it makes sense for them to pay upfront through development charges for infrastructure that will service users for many years. Instead, taxpayers may demand that cities finance infrastructure projects over the long term so that future generations of taxpayers and homebuyers - the main beneficiaries - will also pay for them. The City of Mississauga proudly proclaimed it did not take out debt for decades until 2012, but debt shouldn't be a dirty word.

It is most unlikely that existing homeowners will agree to pay down the debt of building infrastructure in new areas. If that were proposed, they would vehemently oppose any growth within their city. Instead, cities should look to pay for new growth with user fees that apply over the entire time an asset delivers its services. A city that set user fees to cover the amortization and interest costs it pays on asset-related debts would see a balanced budget every year. Accrual accounting would encourage cities to set user fees based on what it actually costs to deliver a service. User fees for water, roads, or other municipal services would match not only the taxpayers who pay with those who use the services but also exactly which households pay for and use the services.

However, many municipal services cannot be fully financed by user fees. Many of the kinds of investments that cities make have intrinsically local benefits, so people want to live near them (see chapter 4). They pay more for houses near parks, better schools, transit stations, and other services. Setting property taxes to increase with property values means that those who benefit from a service pay 
through higher property taxes. In that sense, property taxes are akin to user fees.

What about other investments that have no annual revenue stream from either property taxes or user fees? The healthcare Canadians use today, for example, won't benefit people decades from now. It is a government service - and the user generation should pay for the assets to provide it. Otherwise, future generations would be paying larger amortization expenses than what they could recoup from increased property values or increased user fees.

\section{Alternative Ways to Finance Long-Lived Infrastructure}

How, other than debt, can cities finance needed infrastructure? One alternative is to rely on private operators to deliver services such as waste pickup to water infrastructure (see chapters 6 and 8). Canadian cities have traditionally provided these services on their own, while other cities around the world have increasingly used private companies and achieved better and lower-cost services. Private delivery is best when paired with user fees, but it also works with forms of land-value capture - where governments collect as a tax the increase in property values that result from the improved local infrastructure (see chapter 4).

Private companies would not expect to be paid the whole cost of their investment at once when they build it, but over time as they deliver the service. If cities had an accrual-based budget, they would not see a bottom-line difference between building and then amortizing an infrastructure asset versus paying a private operator every year that the asset is delivered. With their current cash budgets, however, cities look very differently at capital assets they own as opposed to annual expenses to private operators.

\section{Finding Money for Maintenance}

Taxpayers are also concerned that governments are always keen to 
support construction of new buildings or subways but are not concerned with maintaining these assets. Accrual accounting can help with that problem too. As amortization payments on the overall costs of assets trickle into a city's budget each year, they are treated as an expense against the municipal bottom line. However, no actual cash changes hands between taxpayers and any employee or contractor.

A city with a balanced budget on an accrual basis will find itself with plenty of cash on hand. It can use that cash for a variety of purposes: to pay off interest and principal from the debt it used to finance its investment; to pay the private contractor providing the service; or to pay for regular maintenance.

\section{How to Fix Municipal Budgets}

Who would have guessed that something as simple as accounting practices would matter so much in how we view municipal finances? A simple change in how cities present their budgets can transform municipal finances - and, because the provinces generally set the rules in this area, they responsible for making the changes.

A key first step is preparing and presenting municipal budgets that use the same accounting conventions which municipalities already use in their financial reports. Ideally, provinces that directly or indirectly mandate cash accounting in their municipal acts, such as Ontario and Alberta, would change their rules to permit accrual accounting instead of, or alongside, cash. Even without provincial requirements, municipalities could on their own present budget numbers consistent with their financial statements.

Municipalities have been presenting accrual-based financial reports for almost a decade, so presenting accrual-based budgets should not present a major challenge. In addition, accrual-based budgeting would also make the multi-year capital budgets produced by all large municipalities easier to understand by showing the amortization - that is, each year's use - of capital. In short, the 
budget process interacts with municipal governance in important ways (see chapter 5).

\section{Fiscal Rules}

Many people value the requirement that municipalities present balanced operating budgets because they fear that, without it, municipalities would be fiscally irresponsible. That fear is understandable, but responding to it by focusing on, and constraining, the operating budget alone distorts capital spending and its financing. Because accrual accounting consolidates all items affecting net worth into common revenue and expense totals, it gives a more complete picture of an entity's financial position and makes the concept of a separate operating budget irrelevant. The key point is that provincial legislation should not mandate budget targets that are inconsistent with the accrual accounting municipalities already use in their financial reports.

One of the reasons that provinces may be so hesitant to change the rules around budgets is a fear that cities will increase spending dramatically. When the federal government moved to accrual accounting in the early 2000s, there were similar fears. One of the major federal government capital expenses, for example, is military equipment, and the move to accrual accounting made it look easy for the federal government to commit to a great deal of spending. Equipment suppliers salivated over the thought they could sell more to a government that thought the expense looked like less, even though the overall cost was no lower. The increased and already committed capital expense was the next government's problem, and the government of the day was able to take credit for the new military equipment it could show off to voters.

The problem of cities using accrual accounting to tie taxpayers to long-term capital costs could potentially be multiple times worse because so much more capital investment is in the hands of cities compared to the federal government. If provinces change 
budget rules to require accrual-based budgeting, they need to have a framework for fiscal rules so that cities do not take on excessive financial risk.

Canadian cities are behind the rest of the world in adopting modern accounting principles. The good news is that Canadian cities can learn from the experience of places that have already adopted accrual accounting. One such place is Switzerland, where local governments have been using accrual-based budgets for many years, and local governments generally have rules that require them to balance their budgets (see Dafflon 2018). However, these rules are often self-imposed. Only if local governments run chronic deficits do higher-order governments step in with penalties or require them to increase taxes.

Canadian cities should strive to balance their Public Sector Accounting Board-consistent budgets over the course of a council's term, but not necessarily every year. Provinces should allow this kind of year-to-year variation in fiscal balance. They should also permit cities to run an unbalanced budget over the term of one council in the case of emergencies, as declared by the province.

Swiss cities follow fiscal rules that constrain how much they can increase their investment and borrowing. These rules go beyond simplistic questions of setting balanced budget rules; rather, they follow the fiscal "golden rule" of intergenerational equity and commit that long-term revenues will match long-term expenses. Although that rule is quite detailed in its formulation, in practice it states that any additional investment a city takes on should match its change in borrowing. The maximum amount of borrowing should reflect the future costs and revenues from any assets (see Dafflon 2018 for a detailed description). 


\section{Standardized Budget Accounting Rules}

Provincial governments will also have a role in standardizing the assumptions that cities can make in accrual accounting. A key assumption will be around how it values future pension assets and liabilities. Governments tend to overly discount future liabilities by assuming that investments by its pension funds will have above-market returns (Robson and Laurin 2016). Doing so reduces the size of total debt and reduces what governments must pay toward that debt.

Another important question will be the kind of value on which to base the amortization payments for assets. Cities may want to base them not on the original cost of the infrastructure asset but on replacement costs. Using replacement value will allow cities to ask for a more expensive future investment than is now in place. That would be problematic for two reasons.

First, there will never be a clear and verifiable amount for what it would cost to replace an asset at a future date. Cities should not base their books on a speculative asset value. The fair value of an existing and already paid for asset, however, will be abundantly clear and verifiable by an external auditor.

Second, the generation of taxpayers that uses the existing asset should pay for it. When the city eventually needs to replace it with something new, the generation of taxpayers that gets to use that new asset should pay for it.

\section{The New Language of Municipal Finance}

Accounting matters to people on the inside, but not so much to people outside. By looking closely at municipal finance practices, however, we can see the importance for municipal policy of getting it right. With accrual-based budgeting, cities can start to plan their 
finances using modern accounting rules that better reflect matching those who pay with those who benefit.

Now that we realize that cities aren't as poor as we thought they were, it is time to separate the good ways cities are financing themselves from the bad ways. 


\section{Chapter 3}

\section{Cities Aren't Poor: \\ They Don't Need Costly Grants or New Taxes}

The cash-based accounting model used for municipal budgets allows cities, year after year, to cry poor to residents and to senior-level governments. Every budget season, as well as meetings of mayors with senior-level governments, has a similar story: cities need more money. The municipal song sheet usually has two chorus lines: cities need new taxing powers, and the provinces and federal government need to give cities more in grants.

In truth, cities are not broke at all. Recasting municipal finances on the same accounting basis used by the provinces and the federal government shows that cities do not need more money. If anything, it is the provinces that have the largest debt problem.

Do cities really need more revenue-raising options? Many experts have written comprehensive reviews of the economic case for or against specific municipal taxes. Among those outlining the potential revenue-raising tools are publications by Harry Kitchen and Enid Slack (2003, 2016), the volumes in Richard Bird and Enid Slack (2015, 2017), and Bev Dahlby and Mel McMillan (2014). 
They cover municipal personal income tax, sales tax, fuel taxes, and other miscellaneous taxes such as hotel taxes or vehicle registration levies that have limited revenue-raising potential. In my opinion, especially with a move to harmonized federal and provincial sales tax in most of the country, municipal sales taxes are not administratively feasible, ${ }^{5}$ while fuel taxes will diminish in potential value with the increasing use of electric vehicles (see chapter 7).

In this chapter, I will look at three revenue sources in closer detail - land transfer taxes (in Toronto and Montreal), business property taxes, and grants - examining the specific problem with each of them. These three sources have become major contributors to municipal budgets; however, the economic evidence makes a strong case for municipal governments to reduce their reliance on them or eliminate them altogether, either on their own initiative or through the provinces that govern them.

\section{Revenue Sources for Canadian Cities}

The largest single revenue source for Canadian municipalities is property taxes (figure 3.1a). Cities in Alberta and Ontario collect the most per capita, while those in Quebec, having few user fees, rely on property taxes the most as a share of total revenues. British Columbia and Alberta collect the highest level of user fees per capita, with residents there each paying between $\$ 1,000$ and $\$ 1,100$. User fees are such a large share of $\mathrm{BC}$ municipal revenues that they about equal property taxes. Other revenues are fairly consistent across provinces, representing between $\$ 400$ and $\$ 700$ per person. Transfers, both provincial and federal, have wider variability: $\mathrm{BC}$ cities are the least reliant on them, representing about $\$ 175$ per person in revenue, while Ontario cities receive the most, followed by Alberta. Cities in

5 See Dahlby and McMillan (2014) for a thorough discussion of why municipal governments should not have access to either a sales tax or an income tax. 
Figure 3.1a: Municipal Revenue per Capita, by Category, 2015

Dollars

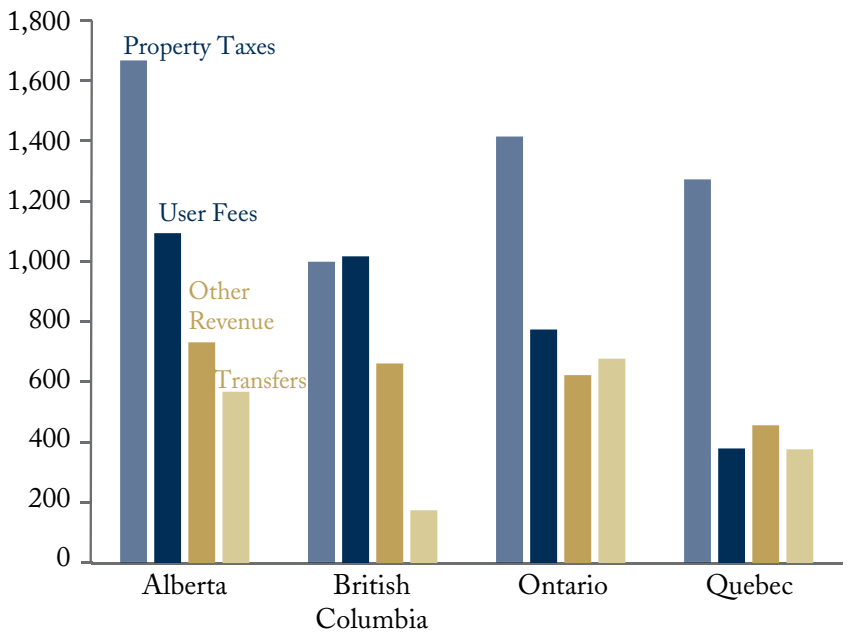

Source: Author's calculations from provincial municipal finance database.

Note: BC revenues include those for Translink, the regional transit authority for Vancouver. Quebec cities with incomplete revenue data have not been included here.

all provinces except Quebec have received an increase in revenues per capita (in 2016 constant dollars) (figure 3.1b). Between 2009 and 2016, revenues grew by 12 percent per capita in Alberta and 16 percent in British Columbia, while they have grown by only 3 percent per capita in Ontario (to 2016) and 5 percent in Quebec (to 2015).

\section{The Economically Costly Ways Cities Raise Revenue}

In this chapter we will consider three revenue types that make up part of the "Other" revenue columns in figures 3.1a and 3.1b and the kinds of property taxes that have especially high economic costs: land transfer taxes (LTTs), business property taxes, and transfers. Residential property taxes and user fees, as more important revenue sources, will be discussed in chapter 4 . 


\section{Figure 3.1b: Municipal Revenue per Capita, by Category, 2009-16}

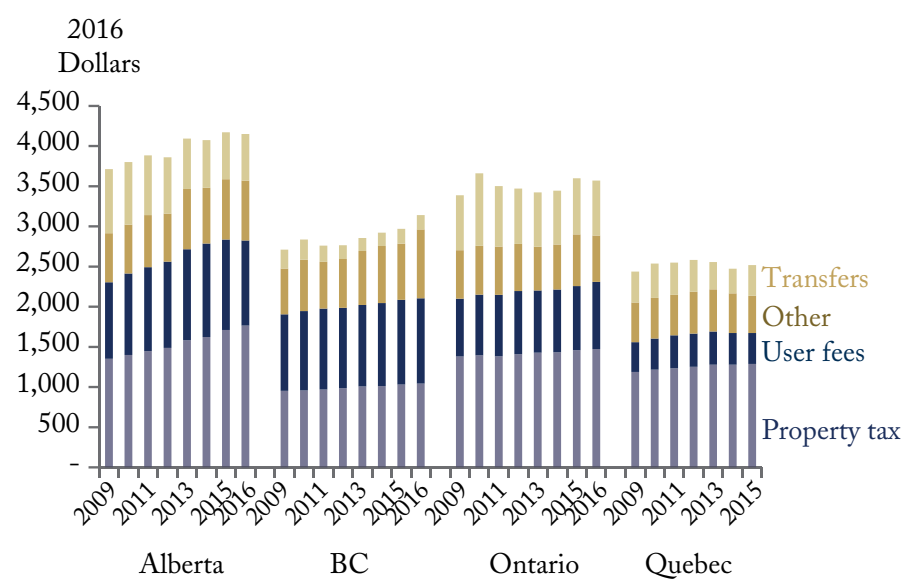

Source: Author's calculations from provincial municipal finance database.

Note: BC revenues include those for Translink. Quebec cities with incomplete revenue data have not been included here. The 2016 data were not available for Quebec at the time of publication.

\section{Land Transfer Taxes}

Several provinces and a few municipalities across Canada levy LTTs. Toronto and Montreal have recently introduced municipal LTTs that apply alongside province-wide LTTs. At the provincial level, British Columbia, Manitoba, New Brunswick, Newfoundland and Labrador, Ontario, and Prince Edward Island all levy an LTT. Among these provinces, the LTTs in British Columbia, Manitoba, and Ontario exhibit progressive rates on transaction values, with the lowest rates of zero, 0.5 , or 1 percent applying on the initial value of the transaction and with a top marginal rate of 2.5 percent. These three provinces collected an estimated $\$ 4.8$ billion in LTT revenues in fiscal year 2016/17, double the amount from 2011/12. New Brunswick, Newfoundland and Labrador, and Prince Edward Island each levy a flat-rate LTT ranging from 0.25 percent to 1 percent 
of the value of a home. ${ }^{6}$ Alberta and Saskatchewan levy land title transfer fees instead of a tax. At an effective rate of 0.02 percent, the Alberta amount is economically insignificant; however, the Saskatchewan rate is 0.30 percent of the purchase cost of a house. In addition, British Columbia and Ontario both introduced new transfer taxes on foreign buyers.

The City of Toronto, under the authority of Ontario's City of Toronto Act, 2006, is the only municipality in Ontario that has the authority to impose its own LTT. Originally 2 percent, the top marginal rate now is 2.5 percent of the value of a house above $\$ 400,000$. With a top provincial and municipal combined marginal rate of 5 percent, Toronto's LTT is the highest statutory rate in North America (Dachis, Duranton, and Turner 2008). In 2017, Toronto collected $\$ 716$ million from the LTT, representing nearly 7 percent of that year's operating budget; as a comparison, Toronto collected $\$ 150$ million in 2008 , representing less than 2 percent of its operating budget.

In an odd twist on assigning taxing powers, Quebec requires municipalities to collect duties on the transfer of property, with a top provincially mandated marginal rate of 1.5 percent for homes with a value over $\$ 250,000$. In January 2010, Montreal introduced two additional brackets, with a higher rate applying at prices above $\$ 500,000$ and above $\$ 1$ million. Montreal's total 2017 LTT revenue was $\$ 153$ million, representing 4.2 percent of its total revenues that year. In 2011 the city collected $\$ 100$ million in that tax, representing 2.7 percent of the city's total revenues that year. Other cities, such as some municipalities in Nova Scotia, also levy a special LTT. Winnipeg, which has the legislative authority to impose an LTT, has chosen not to do so. In general, cities across the country are constantly asking their provinces to grant them the power to introduce such a tax.

6 For details on provincial rates, see http://www.ratehub.ca/land-transfer-tax. 


\section{The Cost of LTTS to Homeowners}

LTTs make up a significant portion of the expense of moving into a new home. The Organisation for Economic Co-operation and Development (OECD) estimates that, in 2007, before the introduction of Toronto's LTT, average total housing transaction costs - real-estate agents' fees, lawyers' fees, existing transfer taxes, and so on - amounted to 7.8 percent of the average property value in Canada (Andrews, Sánchez, and Johansson 2011). The addition of Toronto's LTT, which had an average rate of 1.1 percent for the average sale price of all resale transactions of $\$ 469,00$ in that city from 2008 through June 2012, increased average transaction costs in Toronto by an estimated 14 percent. ${ }^{7}$

To assess the impact of the LTT on household mobility, we distinguished the effect of the LTT from overall market trends and local real-estate market effects. For example, there were significant swings in the economic cycle, particularly in the housing market, between 2005 and 2012. Housing prices and the level of transactions in the overall market rose between 2005 and 2007, only to fall quickly in 2008, followed by an even faster rise starting in 2009 . Accordingly, we isolated the analysis to narrow regions that faced similar economic conditions and local real-estate characteristics, but where some were subject to the LTT and others were not. In practice, this method entails looking at housing sales in small regions along the border of Toronto.

To test the effect of the LTT, we compared the changes in the number of real-estate transactions in suburban municipalities

7 This estimate assumes that other transaction costs as a share of property value are the same in Toronto as in the rest of Canada. However, because some transaction costs are fixed and not a percentage of the sale value, and because property values in Toronto are generally above the national average, the total of other transaction costs as a share of the total property value is likely lower in Toronto than nationally. This point suggests that the LTT resulted in transaction costs as a share of the transaction in Toronto increasing by more than 14 percent. 
along the border with Toronto with those in otherwise similar areas of Toronto that straddle the border of suburban municipalities. By comparing the changes in each area before and after the introduction of the LTT, we estimated how the pattern of real-estate transactions changed in markets that could otherwise be expected to show patterns similar to those of neighbouring markets.

Both the short- and the long-term studies find that the LTT resulted in a 16 percent decrease in sales volume. Although these estimates are based on housing sales along the border of Toronto and its suburbs, this tax-induced gap between what sellers are willing to accept and what buyers are willing to pay applies equally to sales throughout Toronto, not only to those along the border. Based on the number of sales of houses in Toronto as a whole, the net result is that about 3,500 such sales have been forgone each year because of the LTT.

Surprisingly, it's not the homebuyers, the people who write the LTT cheque to the government, who pay the bulk of the economic cost of LTTs. It's the homeowners at the time the LTT is introduced. They have to drop the price of their houses to recognize the higher cost that buyers need to pay because of the tax. The C.D. Howe Institute's initial study of LTTs found that the initial drop in prices was 1.5 percent (Dachis, Duranton, and Turner 2008) - an amount more than the average rate of the LTT (1.1 percent). ${ }^{8}$ The likely reason for this increase is that the current price of real estate embodies not only the reduction in the first sale after the introduction of the LTT but also the sales after that. Buyers recognize that when they sell their houses, they too will have to lower the price to account for the tax.

The effect of the LTT on transactions also varies by average neighbourhood sale price: sellers of homes in areas with lower average values are less willing or able to accept sale prices that are 8 This difference is not statistically significant from zero, but it is suggestive. 
affected by the LTT than are sellers in areas with higher-value homes. Houses below $\$ 400,000$ saw a negligible fall in prices, while more expensive homes saw a reduction on the order of 2.2 percent. Moreover, Toronto residents appear to be substituting home renovation for relocations. These economic consequences of the LTT are likely to be similar in other jurisdictions that have imposed such a tax, especially municipalities such as Montreal that levy a special LTT on top of a provincially mandated LTT.

\section{The Economic Cost of Land Transfer Taxes}

In addition to the above study on Toronto's LTT, studies using various methods around the world from places as diverse as France (Bérard and Trannoy 2017), Germany (Büttner 2017), New York City (Kopczuk and Munroe 2015), Washington, DC (Slemrod, Weber, and Shan 2017), Australia (Davidoff and Leigh 2013), and the United Kingdom (Besley, Meads, and Surico 2014; Best and Kleven 2017) all show the same result: LTTs substantially reduce the number of housing transactions. The world has also learned about the broader economic costs of these levies. The C.D. Howe Institute's first study estimated that the dollar value of lost mobility is about 13 percent of every $\$ 1$ of revenue that the LTT generates for Toronto's coffers.

Another study of the similar United Kingdom tax (Hilber and Lyytikäinen 2012) found that the economic cost was 29 cents for every $\$ 1$ of government revenue and that the economic costs accelerate as the tax rate increases.

By tracking households over time, before and after they move, the UK study examined the kind of household moves that transfer taxes stymie. They tend to reduce moves within a city, rather than those at longer distances or for job changes. The major economic costs to homeowners are that they can't afford to purchase larger houses for growing families; they suffer through increasing traffic congestion year after year to get to their same jobs; or they don't have access to 
neighbourhoods with the kinds of schools they want their children to attend.

When a piece of land or real estate changes hands multiple times, the LTT can end up being applied more than once on the same project - or on variations of it - during its construction process and final sale, creating a "tax cascading" effect. ${ }^{9}$ For example, a developer who purchases vacant land from a landowner would pay the LTT on the initial purchase. If that developer then chose to resell the vacant property to another developer, who then builds homes on it, the LTT would apply at three different stages in the construction and sale of a home and would either be embedded in the final purchase price for the buyer or result in a lower sale price for the landowner. LTTs become an appreciable part of the cost of doing business in a number of Canadian cities (see below).

\section{Why LTTS Aren't a Good Revenue or Policy Tool}

Part of the reason why the LTT is an inefficient tax is that it is applied to a relatively narrow base - the subset of properties sold in a given year. Residential property taxes, which are applied to all homes in a municipality every year, have few of the distortionary effects on mobility or the economic costs of an LTT. Perhaps policymakers will be convinced that LTTs are bad taxes when the revenues from them dry up. The early indications for 2018 are not good, with Toronto home prices flat and sales down almost 30 percent from the previous year.

What do the data say? The latest Canada-wide statistics on local government financial data show that LTTs have a higher degree of year-over-year variability than other major municipal revenue sources - general property taxes, user fees, and even transfers from government. Land transfer taxes (which Statistics Canada measures as taxes on other property) had double the degree

9 This effect is somewhat alleviated by section 9.2 of the Ontario Land Transfer Tax Act, which provides a limited refund of up to $\$ 2,000$ on the LTT due on newly constructed owner-occupied housing. 
of variation of these other sources (Dachis and Kim 2018a). Just before he left his position as Toronto city manager, Peter Wallace raised this issue in his Roadmap to Financial Stability presentation, stating that Toronto has become too reliant on a hot property market feeding municipal finances through the LTT (Toronto 2018a). In response, City Council failed to take any action, and the dependency on the LTT revenue roller coaster continues.

This high variability of revenue is due to the cyclical nature of real-estate markets, making budget planning difficult for cities with an LTT. Between 1991 and 1992, total Canada-wide revenues from LTTs increased 62 percent (the largest annual increase since 1988), while LTT revenues fell by 17 percent in 1990 and by 14 percent in 1995. Toronto's LTT began at the bottom of the last-real estate cycle, so the revenue volatility the city has faced since then has all been upside. That trend will not last forever. The city, along with other provincial and city governments around the country, will face a big budget decline during the next real-estate market downturn. The City of Toronto has benefited from a cumulative $\$ 460$ million in unexpectedly high revenues from 2015 through 2018 (Toronto 2018a). A similar shortfall in budget forecasts would result in wrenching service cuts or large property tax increases to fill a budget void.

In support of LTTs, policymakers state that they curb real-estate market speculation and reduce the volatility of house prices. This reasoning has been used to introduce foreign buyer taxes in Ontario and British Columbia. Although higher transaction costs might reduce price volatility by reducing the number of speculative transactions, this effect is relatively small compared with that of other factors, such as banking supervision, increasing the responsiveness of housing supply to demand, or decreasing the maximum loan to value ratios of insurable mortgages (Andrews, Sánchez, and Johansson 2011). 


\section{Business Property Tax Rates and Amounts ${ }^{10}$}

Property taxes are, by far, the largest broad source of municipal tax revenue. However, not all property taxes are created equally. Municipal residential property taxes make up most of the total in Ontario, where they represent about 75 percent of total property taxes collected in Ontario. In contrast, residential property taxes cover less than half of the total property tax revenues in Alberta, where property tax rates on non-residential properties are much higher than on residential properties (figure 3.2a). The total revenues depend on both the tax rates and the size of the tax base. Alberta cities have a large industrial base - oil facilities, for example. Ontario's business tax base is not as robust. On average across Canadian cities, the non-residential tax rate between 2009 and 2016 was between double and triple the rates on residential properties (figure 3.2b). Some cities have much higher taxes, and others, lower, than these averages.

\section{Business Property Taxes across Canada}

Typically, governments structure their business property tax regimes so that effective rates differ from their statutory rates. ${ }^{11}$ There are also different rates for different kinds of property: large industrial properties typically pay higher tax rates than smaller ones. Although each provincial and local property tax system is unique, Adam Found and Peter Tomlinson have developed a standardized methodology to transform statutory business property tax rates into effective ones for each jurisdiction (table 3.1). Business property tax rates often differ across municipalities because of differential statutory rates by property type and differences in provincial and municipal assessment mixes. For greater intermunicipal consistency, Found and Tomlinson

10 Some of the text used in this section is taken directly from Found, Tomlinson, and Dachis (2015); some of the numbers, figures, and calculations are from more recent versions of this work (Found and Tomlinson 2016, 2017).

11 Statutory rates are the advertised rates. Effective rates are what taxpayers end up paying as a share of actual property value. 


\section{Figure 3.2a: Municipal Property Taxes per Capita, 2009-16}

2016

Dollars

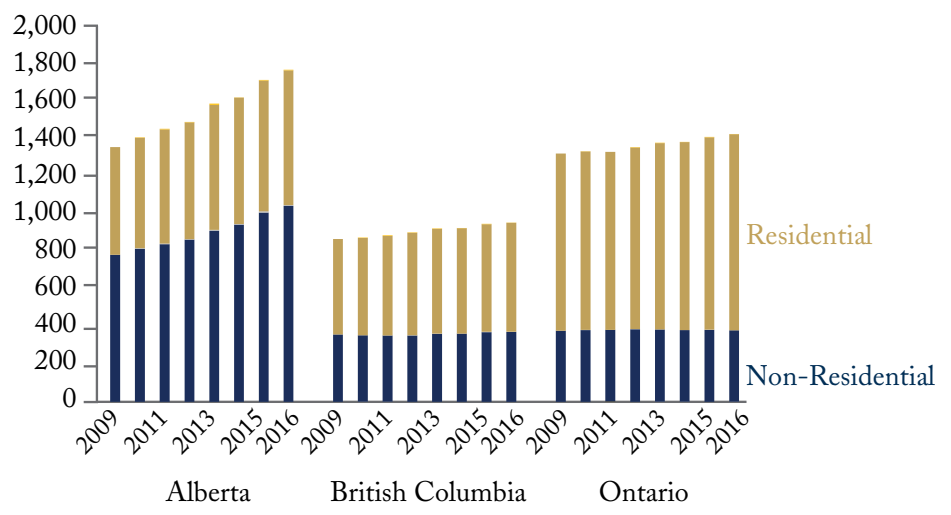

Figure 3.2b: Taxes as Share of Assessed Value, 2015

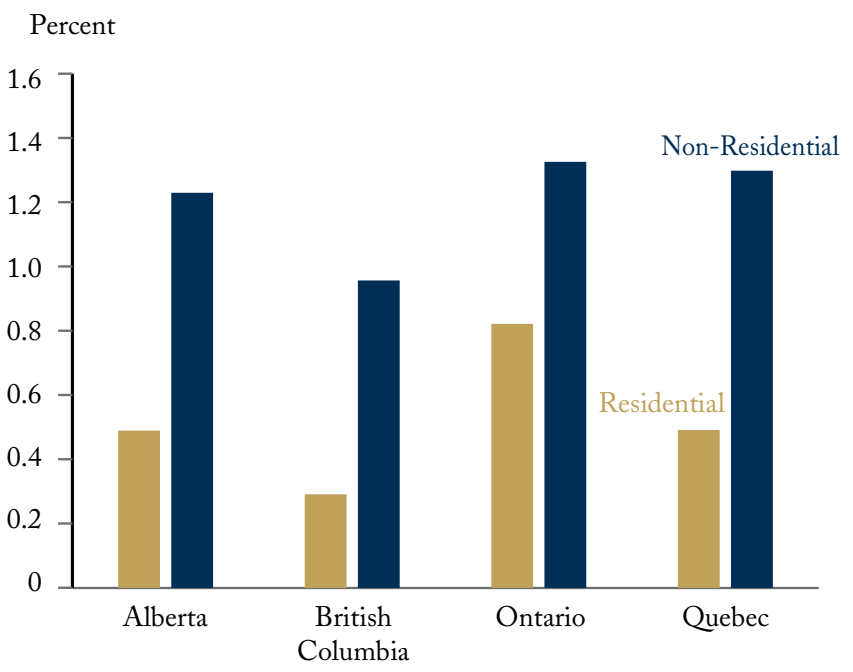

Source: Author's calculations from provincial municipal finance database. 
calculate effective provincial business property tax rates on a municipality-specific, not province-wide, basis. The studies have been limited to analyzing the largest city in each province, largely because collecting this city-specific data is time intensive.

Both effective and statutory business property tax rates vary enormously across the country. In a simple business property tax system, business assessments would be based on a market valuation date no more than one year before January 1 of the current taxation year, while a uniform tax rate would apply to all business property. In this ideal state, there would be just one effective tax rate, and it would be the rate shown on tax bills. Typically, however, governments introduce elements of complexity, such as multiple business classes with differential tax rates, discounts applying to specified assessment categories, and valuation dates several years back in time. Found and Tomlinson painstakingly take these differences into account when coming up with a total effective tax rate. Among the largest cities in each province, the lowest municipal rates are in Saskatoon and Vancouver, where the statutory rates are similar to the effective rates. Montreal continues to have the highest local tax rate, followed by the four Atlantic municipalities and Winnipeg. Calgary and Toronto have local business property tax rates below that of the national average, but much higher than those in Vancouver and Saskatoon.

These municipal taxes are only part of the problem. In most provinces, there are additional provincially set property taxes. The majority are notionally earmarked for education. Yet, across most of Canada, each school board's total revenue is based on its enrolment and the needs of students, not the value of buildings in the area. That means the provincial property tax now has no bearing on school boards' spending. Most provinces still use the misleading name "education property tax" to describe it on tax bills (see Found 2017 for more details on the problem with provincial education taxes, particularly in Ontario). 


\begin{tabular}{|l|c|c|c|}
\hline \multicolumn{1}{|c|}{ Table 3.1: Business Property Tax Rates in Largest City of Each Province, 2017 } \\
\hline \multicolumn{1}{|c|}{ City } & $\begin{array}{c}\text { Municipal } \\
\text { Statutory Rate }\end{array}$ & $\begin{array}{c}\text { Municipal } \\
\text { Effective Rate }\end{array}$ & $\begin{array}{c}\text { Total Effective } \\
\text { Rate (Including } \\
\text { Provincial) }\end{array}$ \\
\hline Vancouver & 0.73 & 0.73 & 1.22 \\
\hline Calgary & 1.52 & 1.43 & 1.83 \\
\hline Saskatoon & 0.70 & 0.71 & 1.25 \\
\hline Winnipeg & 3.27 & 1.81 & 2.39 \\
\hline Toronto & 1.35 & 1.02 & 3.61 \\
\hline Montreal & 3.76 & 3.61 & 4.88 \\
\hline Saint John & 2.68 & 2.68 & 3.32 \\
\hline Halifax & 2.98 & 2.98 & 3.86 \\
\hline Charlottetown & 2.36 & 2.36 & 2.21 \\
\hline St. John's & 2.47 & 2.21 & 2.09 \\
\hline National Average & 1.78 & 1.58 & \\
\hline Source: Found and Tomlinson & 2017. & & \\
\hline
\end{tabular}

\section{Why Business Property Taxes Are a Problem}

If any tax a business pays resulted in a direct benefit equal to the tax, there would be no net tax burden on businesses. Taxes would have no effect on the location and quantity of capital investment. Jurisdictions with relatively high tax rates would deliver superior services, which, from the standpoint of businesses, would balance the extra taxes. A number of studies, however, undermine the benefit-tax scenario's plausibility (for example, Kitchen and Slack 1993; Mintz and Roberts 2006). They find that municipal property tax burdens - levied on businesses as a class - substantially exceed the benefits businesses derive from services financed by property tax. Given the imbalance of tax burdens and benefits for businesses as a class, it follows that a typical business would, to some degree, view its property tax payment as a net burden. 
These high property taxes therefore have a large economic cost. Property taxes act like a tax on capital - specifically, building capital. A tax on capital reduces the incentive to invest, and lower investment leads to lower productivity and lower income and standards of living for Canadians.

The ideal way to measure the effect of taxes on a company's decision to invest is through the marginal effective tax rate (METR) on investment. The METR is the measure of the wedge between the rate of return a company needs to earn before taxes to satisfy investors and what it must earn to pay both investors and taxes. ${ }^{12}$ For example, if the global gross rate of return that a company expects is 10 percent, but it must earn 12 percent to be able to pay taxes, the METR is 20 percent ([12\%-10\%]/10\%).

For too long, these business property taxes have been the silent, largest cost on business investment in Canada. We have consistently found that business property taxes - both local and provincialand land transfer taxes represent about two-thirds of the total METR on corporate investment. When the federal government produces its estimate of which parts of Canada are the most tax-competitive, Atlantic Canada usually comes out ahead. However, those figures ignore the costly property business taxes. Found and Tomlinson have consistently discovered that the largest cities in the Atlantic provinces have the overall highest tax burdens on investment, followed by those in Quebec and Manitoba. Saskatoon, Calgary, and Vancouver have the lowest tax burdens, while Toronto and St. John's are on par with the national average. The biggest drivers of these differences are provincial and especially municipal property taxes, as table 3.1 and also figures 3.3-3.5 make clear.

12 To attract investors, the rate of return from a company must be greater than other options they have to earn returns elsewhere, such as by investing in safe government bonds. 


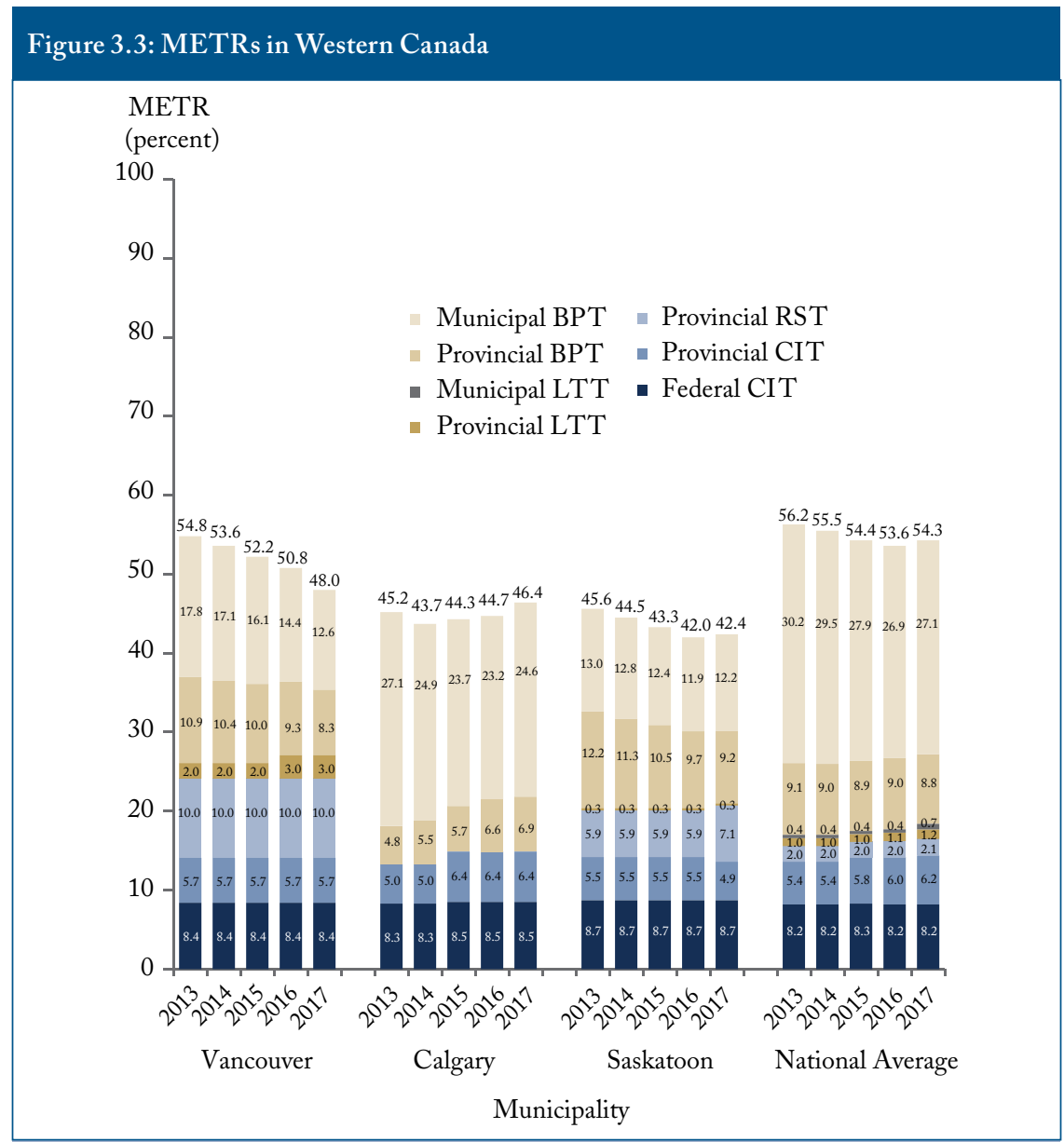

Source: Found and Tomlinson 2017.

Hikes or declines in property taxes have also been major causes of change in the ranking of cities by tax burden. British Columbia and Saskatoon have seen the largest reduction in METRs, thanks to falling municipal tax burdens.

These business property taxes have both economic costs and fiscal costs. A higher tax-induced cost of investment will result in fewer investments being worthwhile and, therefore, lower 


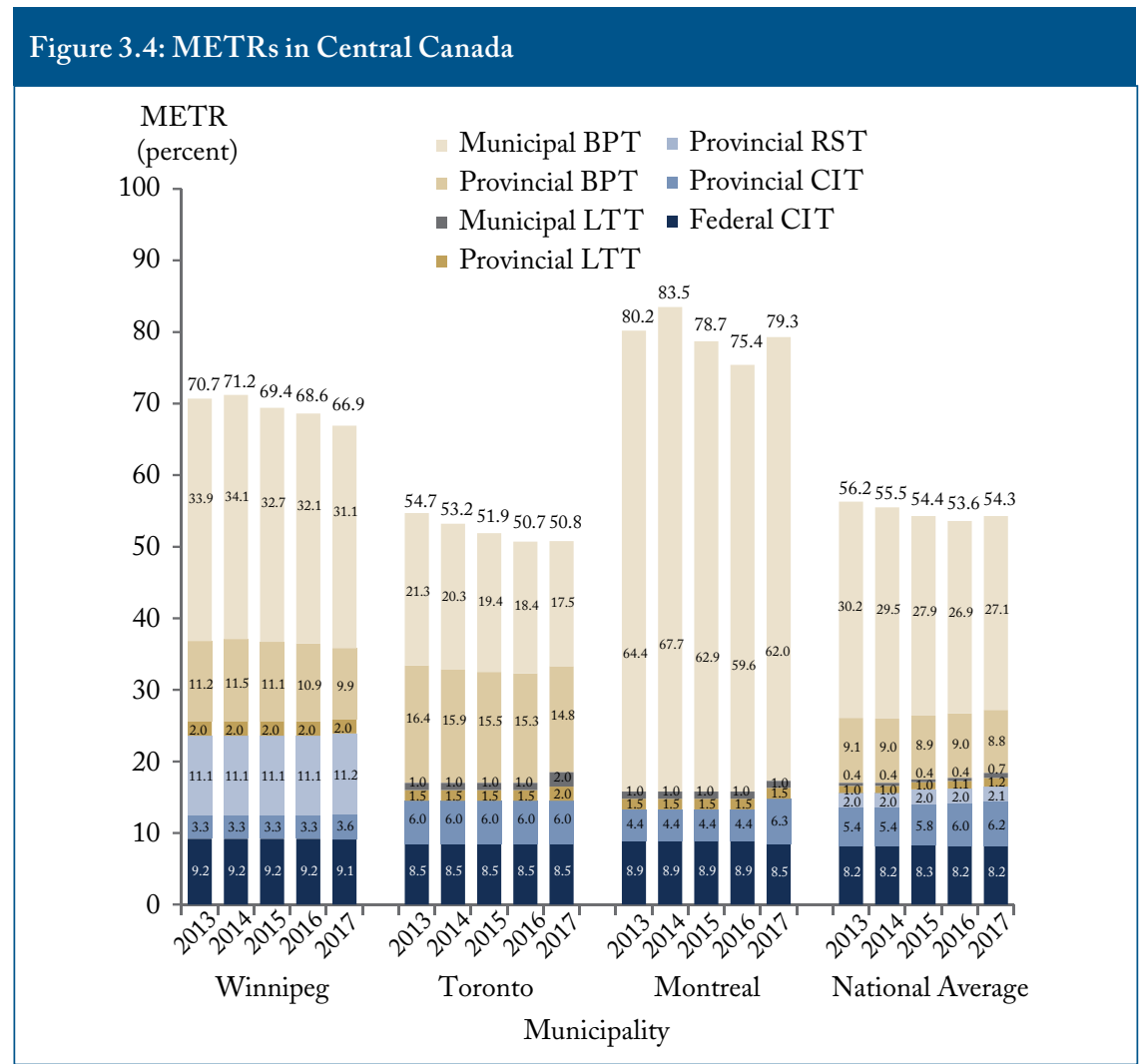

Source: Found and Tomlinson 2017.

investment. A 10 percent increase in commercial property tax rates decreases the long-run value of the business property assessment base by 8.2 percent. At the average level of business property taxation in Ontario, a $\$ 1.00$ business property tax hike costs the Ontario economy $\$ 5.56$ (Found 2017). Higher taxes shrink the tax base, which makes it harder for governments to raise revenues. This shrinking tax base occurs for two reasons: a capitalization effect, in that properties have a lower value because owners know they will need to pay higher taxes in the future; and lower investment, because companies cannot afford to pay the taxes and do not invest in the first place. 


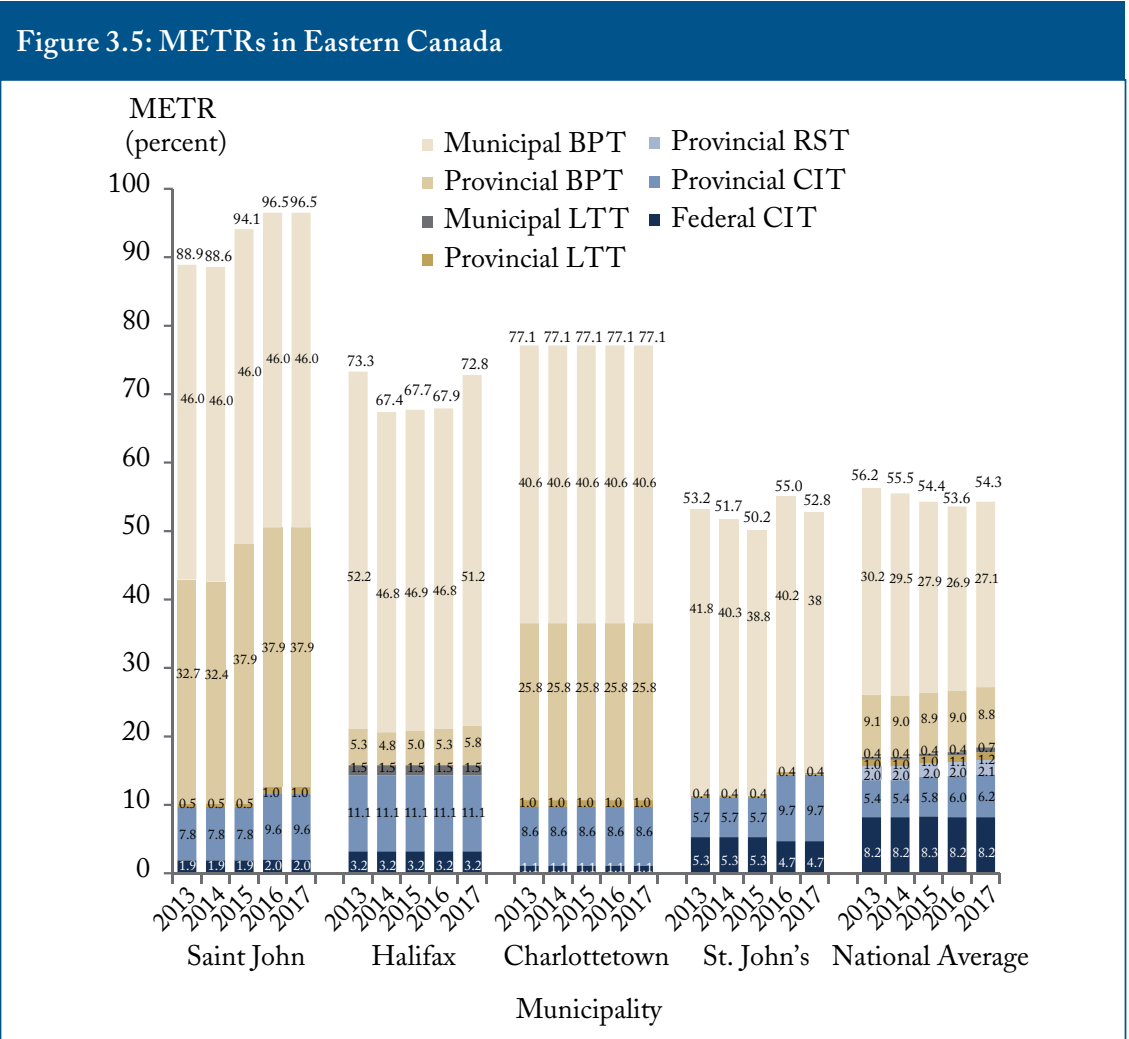

Source: Found and Tomlinson 2017.

The total business tax rates in some cities across Ontario such as London, Windsor, and Brantford - are so high that cities and the province could see revenues increase if they cut their taxes to attract more business investment (see Found 2017).

\section{There Are No Free Lunches: The Problem with Provincial and}

\section{Federal Grants}

Grants are one of the largest sources of revenue for many Canadian cities. However, there's great variability in both the levels and the trends of grants given to cities (figure 3.6). Grants from provincial 


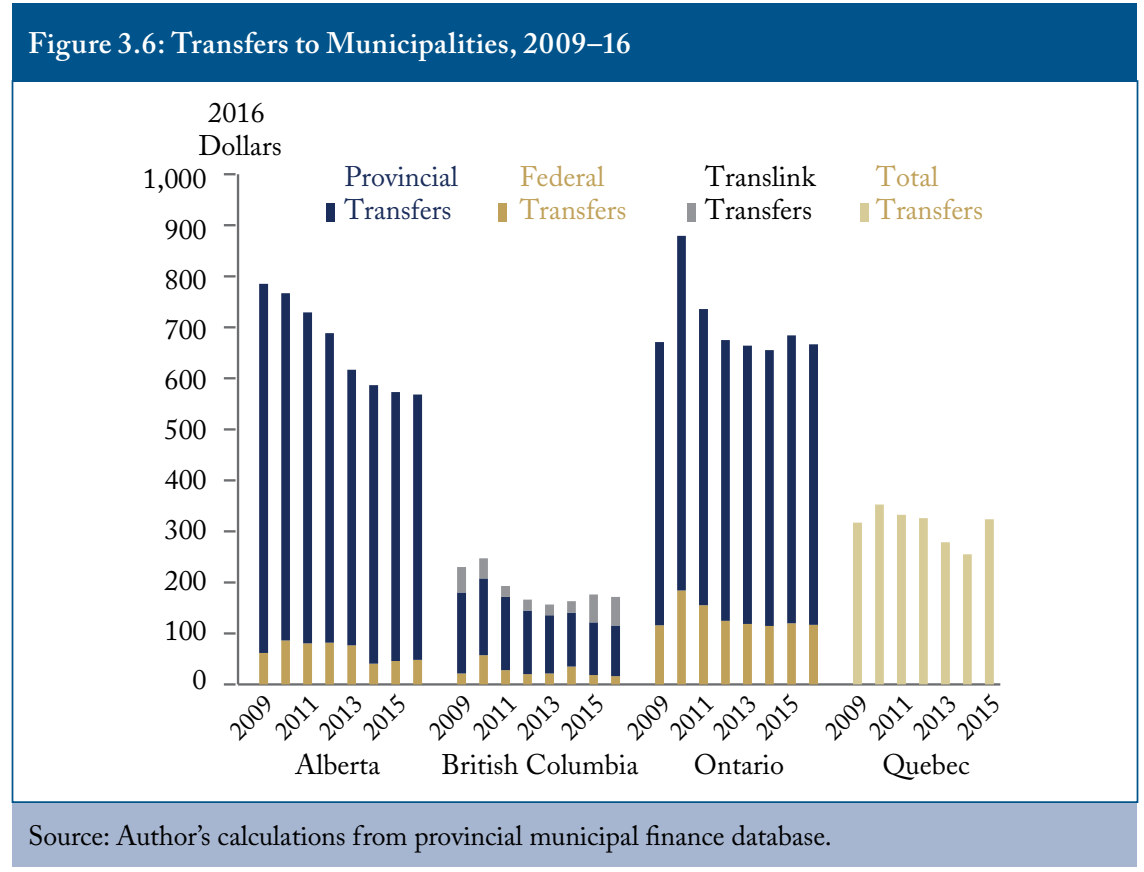

governments to municipal governments are far more important than grants from the federal government. Of the four major provinces, only Quebec does not distinguish how much of the grants given to cities came from federal and provincial sources. In all, federal grants make up no more than a quarter of the total grants to cities.

The amounts also vary substantially. Cities in British Columbia receive the least: including transfers to Translink, the regional transit authority for Vancouver that is governed by municipal governments, transfers per person have never been much more than $\$ 200$ per person (see chapter 5). Quebec is the middle of the pack, with around $\$ 300$ per person in transfers. Ontario and Alberta municipalities receive much more, but the trends have been reversing. Alberta municipalities were receiving around $\$ 700$ per capita in the late 2000s, but those amounts fell to less than $\$ 600$ in recent years. Ontario transfers have been consistently ratcheting upwards, 


\section{Figure 3.7: Provincial Transfers to Ontario Municipalities, 2009-16}

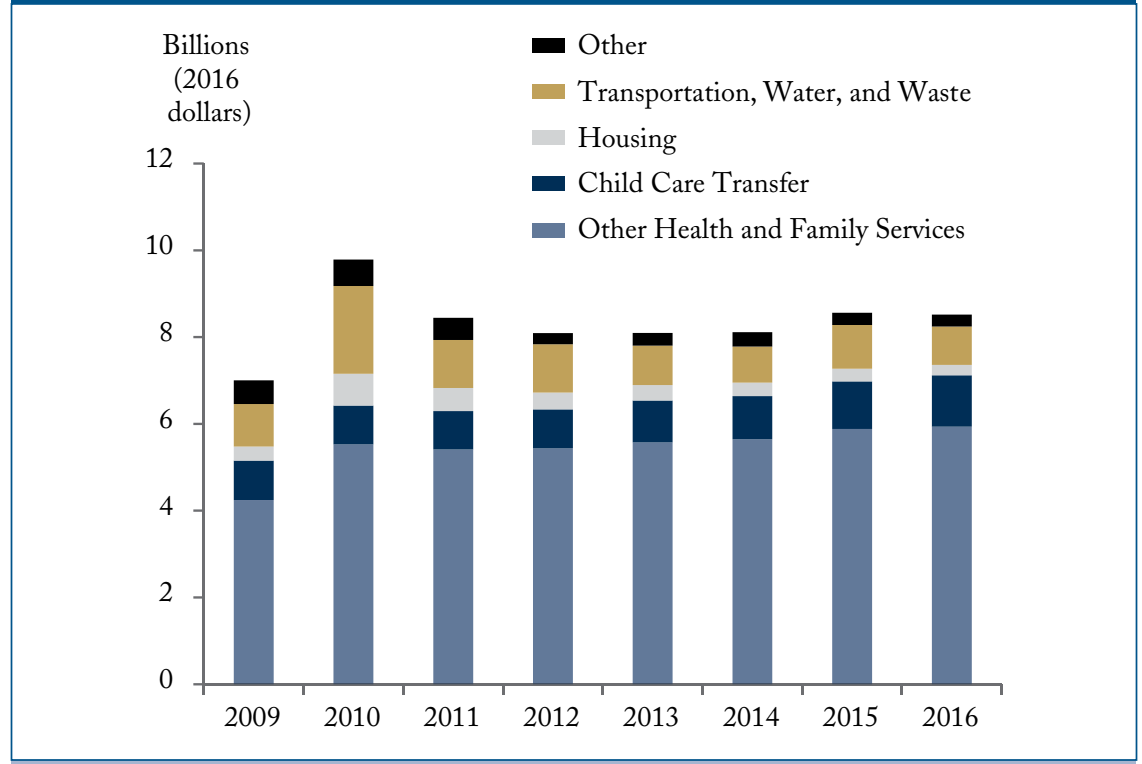

Source: Author's calculations from Ontario Financial Information Return Schedule 12.

including a large spike in 2010 as part of an infrastructure spending stimulus in the face of the recession.

Ontario provides detailed data on these transfers to municipalities through the Financial Information Return (see chapter 1). In Ontario, transfers to municipal governments from the province are now more than $\$ 8$ billion (figure 3.7). Between 2003 and 2010, these transfers grew at an annual rate of 14 percent (Côté and Fenn 2014). Although growth has since slowed, this trend was set to accelerate under the Liberal provincial government, which lost the 2018 election. In January 2017 the province committed to double the amount of the fuel tax it transfers to municipal governments to support investment in transportation (Jones 2017). Ontario transferred $\$ 335$ million in provincial gas tax revenue to municipal governments 
in 2017 and made a commitment to double the funding to bring the total transfer to $\$ 642$ million by $2021-22$.

The increase in transfers in Ontario is a result of local service realignment. Ontario is unusual in that a large share of the social services is delivered by municipal governments (see chapter 6). Up until the 1990s, the province funded almost the entire cost of these services through grants. It was then up to cities to figure out how they would deliver them. In the late 1990s the province reduced the share of key services it would partially fund: for example, it reduced the share of transit tax-supported operating costs it would cover from one-third to zero. The subsequent government reversed course, and, as of 2018, nearly all social services are fully funded by grants from the province. However, the provincial government has, for good reason, not restored its grant funding of core municipal services, such as for police, water, and transit.

The largest share of transfers is for family and health services - such as public health or social programs - and for childcare benefits delivered by municipal governments. The latter are large and are dispersed to municipalities under a complex set of qualification criteria. The childcare transfer has increased by nearly one-third since 2008 and, in 2016, reached $\$ 1.2$ billion. These programs - which are outside of the scope of a book on inherently municipal issues are ripe for review and evaluation to determine which level of government is best placed to deliver them. Their impact on workforce participation, particularly for single-parent and underrepresented families, is critical. In general, the provincial transfer of money to cities to enable them to deliver social services adds unnecessary complications to the system.

\section{The Economic Harm of Grants}

Grants from the provinces to municipalities seem especially perverse, given the vastly different degree of fiscal health between the 
two levels of government (see chapter 2). There are, in fact, even stronger reasons for provinces to cut back on grants.

Grants from a higher order of government create numerous problems for local governments (Kitchen 2006). They can lead local governments to spend more on low value-for-money projects when failure to use a grant risks losing access to federal funds. Governments can partly alleviate this problem by placing no conditions on how local and provincial governments spend capital grants. No matter the circumstances, however, higher-level grants to lower-order governments reduce the accountability of the recipients. As well, the lack of transparency confuses voters, who often do not know which government is responsible for the tax-raising and spending choices. As a result, governments end up spending more on wasteful projects. Data from the United States shows that, as grants for local infrastructure from a higher level of government increase, the amount of low-value infrastructure expenses also increases (Glaeser and Ponzento 2017). When voters are not informed about the spending decisions, they perceive only the benefits of local infrastructure, not the cost.

\section{The Limited Case for Grants}

There are, however, two economic rationales for grants. The first is that, as a society, we deem that one group of people needs the money more than others do. The marginal value of money for them is likely to be higher than for those in the rest of society. ${ }^{13}$ That reasoning might mean giving grants to groups such as Indigenous communities, low-income groups, and others in need. However, it is not clear what role municipalities need to have in such redistribution. Only in situations where local governments don't have the right distributional financial tools to raise the revenue for these kinds of services, yet are clearly the right level of government to deliver such redistribution, might transfers make sense.

13 This basic philosophical argument, expressed in economic terms, derives from John Rawls, A Theory of Justice (1971). 
The second justification for grants occurs when there is some form of interjurisdictional spillover (Dahlby and Jackson 2015). For example, the benefits of a project may spill across provincial borders, and the kinds of taxes the granting government levies might be less economically damaging than those collected by another government to which it grants money. International, interprovincial, and even key transportation hubs wholly within a province can, for instance, expand trade for producers across the country and may be suitable projects for the federal government to support. In addition, there is another way of capturing interregional spillovers: by creating a single regional body that is responsible for both the money-raising and the spending dedicated to specific projects (see chapter 5).

The spending by a lower level of government may result in higher incomes for local residents, who then pay higher taxes to multiple levels of government. These "agglomeration benefits" arise from improved transportation infrastructure (see chapter 7). Federal and provincial governments should quantify the extent of these spillovers for projects and support local infrastructure only to the extent such development is best placed to enhance these spillovers - as when local governments would otherwise not see such a benefit.

\section{The Most Economically Costly Ways to Finance Cities}

How do we think about the economic cost of all these taxes? In addition to the METR analysis used above, the other main way of assessing the economic harm of taxation is through what is called the marginal cost of funds. When users pay the full cost of infrastructure, they equate private rates of return with social rates of return: that is, user fees have no externality cost on the rest of the economy. Municipal user fees and residential property taxes provide excellent examples (see chapter 4).

For all other public expenses and investments, the difference between user charges and costs must be covered by taxes. Raising 
taxes imposes a cost - the marginal cost of public funds - on the overall economy, lowering the social rate of return of a particular expense or investment. When a government raises an additional dollar of revenue through taxes to finance day-to-day operations or an infrastructure project - whether through income tax, fuel taxes, a consumption tax, or any other tax not directly related to the use of infrastructure or government service - it affects the decision-making of a firm or a person subject to the tax. This increase is an economic harm, because a firm may put off hiring decisions, for example, or a consumer may delay spending decisions. The marginal cost of funds measures the change in economic behaviour due to a government raising additional revenue and varies by the type of tax used, with corporate income taxes having the highest cost, and consumption taxes having the lowest (Dahlby 2009).

The main sources of revenue that we've discussed in this chapter have some of the highest possible costs of public funds. Adam Found (2017) estimates that the cost of marginal funds of business taxes per dollar is $\$ 5.56$ on average and that in some cities which could see increased revenue from lower taxes the cost is infinite. The other main municipal tax we discussed, land transfer taxes, has a marginal cost of funds as high as $\$ 5.65$, according to some other studies. What about provincial grants? The marginal cost of public funds depends on the kind of tax that provinces increase to finance grants to the lower-tier governments. If they use costly personal or corporate income taxes, two of the main sources of provincial government revenue, the marginal cost of funds is between $\$ 5$ and $\$ 7$ - the same amount. And that doesn't include the accountability problem connected to grants which we discussed above. The marginal cost of funds from consumption taxes, such as sales taxes, is lower.

\section{The High Cost of Politically Cheap Revenue}

Canadian cities have become too reliant on grants and taxes that are 


\begin{tabular}{|c|c|}
\hline Tax & Marginal Cost of Funds \\
\hline Business Property Tax & $\$ 5.56$ \\
\hline Land Transfer Tax & $\$ 1.00-\$ 5.65$ (global range) \\
\hline \multicolumn{2}{|c|}{ Provincial Grant Sources (Ontario): } \\
\hline Personal Income Tax & $\$ 6.76$ \\
\hline Corporate Income Tax & $\$ 5.21$ \\
\hline Sales Tax* & $\$ 1.92$ \\
\hline \multicolumn{2}{|c|}{$\begin{array}{l}\text { *This sales tax marginal cost of funds is for the similar Quebec tax; Dahlby and Ferede (2016) find i } \\
\text { technically impossible to calculate the Ontario result. } \\
\text { Source: Dahlby and McMillan 2018; Dahlby and Ferede 2016; Found } 2017 .\end{array}$} \\
\hline
\end{tabular}

economically costly. Grants seem to be a cost-free way for cities to provide services, but they have the downside of reducing accountability. Business property taxes have had a large economic cost, as have land transfer taxes in the few cities that have introduced them.

Research by the C.D. Howe Institute into the introduction of Toronto's land transfer tax in 2008, and subsequent related work (Dachis, Duranton, and Turner 2012; Dachis 2012), was the first in the world to estimate the economic harm of the tax. These studies, and many others, have shown that land transfer taxes have a large economic cost. This tax has also left Toronto's finances dangerously vulnerable to a downturn in the local real-estate market.

Property taxes for businesses are disproportionately higher per dollar of assessed value than for residential properties. These taxes have both economic costs and fiscal costs: a higher tax-induced cost of investment will result in fewer business investments in a city, and that means fewer jobs for a city's residents. Some cities in Ontario have business property taxes that are so high that cutting tax rates could result in more revenue. 
Finally, grants have long represented the easy way out for local governments: they get all the benefits of cutting ribbons on new projects or offering better services but do not need to face voters with the tax bill. It is a great deal for municipal politicians, but not for taxpayers. Someone has to pay the bill - and the hidden bill in terms of reduced economic activity is often steep. Grants mean that voters do not know which level of government is responsible for taxing and spending.

It's time for municipal governments across Canada to reduce their tax take from the kinds of taxes and grants that they have come to rely on. What are the smarter, though less politically popular, ways for cities to fund themselves? 


\section{Chapter 4}

\section{Smart Ways to Fund Municipal Services}

The reason that cities have become so reliant on revenue sources such as business property taxes, grants, and even land transfer taxes in the case of Toronto is that, compared to other options, they are the most politically palatable. They are popular because most people think they don't need to pay them. They want someone else to pay that tax. Rather than have a broad swath of society pay the taxes that finance local government, it's far simpler for politicians to say, "Don't tax you, don't tax me, tax that man behind the tree."

The problem is that looking behind trees for businesses to tax, for grants, and for revenues dependent on a volatile real-estate markets has both high economic costs and fiscal consequences, although each for different reasons (see chapter 3). Instead, cities should increase their reliance on taxes so that as many people as possible pay, broadening the tax base to the point where everyone pays as little as possible. That means a tax - or a user fee - whenever you use or benefit from a municipal service.

Many municipal councillors don't like relying on residential taxes or user fees to finance municipal services because voters can 
then hold them accountable. That makes these taxes good taxes, and, in addition, the property assessment system matters too. An up-todate market value system - which Canada largely follows, more so than much of the rest of the world - is the fairest and most transparent way of linking property values with what homeowners pay in tax.

Property taxes are an ideal way to finance the broader municipal services that can't be financed with user fees. Improvements to neighbourhoods or cities that get reflected in property values make the property tax akin to a user fee. However, property taxes are not an ideal way to finance services that are of a more redistributional social service, such as social housing or employment.

User fees are the second major source of revenue that cities should rely on. Parking in particular is a sizeable potential revenue generator, and they could supplement the water and waste collection fees that now form the bulk of municipal-level user fees. Cities should use technology that adjusts parking prices based on the given demand and supply of parking spots, thereby enabling smarter parking pricing. Smarter prices could lead to more available parking, a lower average price of parking, less congestion, and more revenue for the city.

\section{Residential Property Taxes in Canada}

Canadian cities are among those that, worldwide, are most dependent on property taxes. These taxes are the equivalent of 3 percent of the total Canadian economy - an amount that, in 2010, was the second highest among OECD countries, behind only the United Kingdom and slightly ahead of the United States (Bird and Slack 2015). Except in Alberta, residential property taxes make up the bulk of property taxes in most of the four major provinces (see figure 3.2).

\section{The History of Residential Property Taxes}

There is a common saying that the best kind of tax is an old tax. Any 
new tax will result in a new constituency upset with having to pay more for government services. Politicians therefore stick to the old taxes currently in place. It's usually easier to preserve the status quo than to venture forth boldly with a new tax.

On this standard alone, a property tax is as good a tax as one can imagine. Indeed, the very first tax in Canada - before our country was called Canada - was a property tax. In 1793, soon after the founding of the colony of Upper Canada (later Ontario), residents started to pay a tax on both their real-estate property and other personal property. ${ }^{14}$ The Ontario property tax system evolved by a series of fits and starts into the system we have today. ${ }^{15}$

Before the First World War in Ontario it had many elements of an income tax, because some of a person's income was considered "property." However, the need for the federal government to institute a "temporary" income tax to finance war efforts meant that cities had to vacate that area and stick to a tax only on physical property. More than one hundred years later we're in the same position: our "temporary" tax is now the backbone of provincial and federal finance, and cities are mostly dependent on property taxes.

Quebec has an unusually high reliance on property taxes at the municipal level, with relatively little coming from user fees (see figure 3.1b). One of the main reasons is that many Quebec municipalities do not collect water charges from customers and instead levy a distinct water charge as part of municipal property taxes. Indeed, this custom emerges from the history of Quebec municipal water systems. In 1845, to help facilitate urban development, the City of Montreal - then Canada's largest city, with 20 percent of Canada's urban population - bought the private company that

14 This review of the history of property taxes is based largely on Bird, Slack, and Tassonyi (2012), chapter 3.

15 See Heamans (2017) for an even more exhaustive history. 
had been supplying water to residents. With water meters yet to be invented, it was simpler for the city to put the cost in property taxes. Other cities in Quebec followed suit, and fiscal inertia has kept water financing largely on the property tax base (Meloche and Vaillancourt 2017).

Western Canada became populated in the time of land booms in the early 1900s. As the price of land itself went up, it became an attractive tax base for local government. Taxing land, as opposed to the building on top of any specific site, is an economically attractive option (see below). Western Canada was the Canadian hot bed of this idea of taxation, which was popularized by Henry George, a widely read American political journalist in the late 19th century. However, the 1930s Depression sapped much of the value of land, and therefore the tax base of cities reliant on land values as opposed to buildings as well (Bird, Slack, and Tassonyi 2012).

\section{The Property Tax in Canada Today}

Property taxes as a total share of household income have also remained relatively steady. As Dahlby and McMillan (2018) show, property taxes as a share of total income today are not appreciably different from what they have been over the last 60 years (figure 4.1). What has changed most is how these tax dollars are spent. Across Canada, municipal finance was closely entwined with education finance because local school boards had property-tax levying powers. By the 1990s, however, most Canadian provinces had fully taken over most property-tax setting powers for the notional purpose of education, even though the fiction that they are entwined with financing education persists. Most provinces still call the provincially set property tax an education tax. These provincial taxes are higher on businesses than on residents (see chapter 3).

There are a number of consequences from sharing the residential tax base. The key problem is that, as with grants, taxpayers don't know who to hold to account for properly spending their 
Figure 4.1: Property Taxes as a Share of Household Income, Canada, 1988-2016

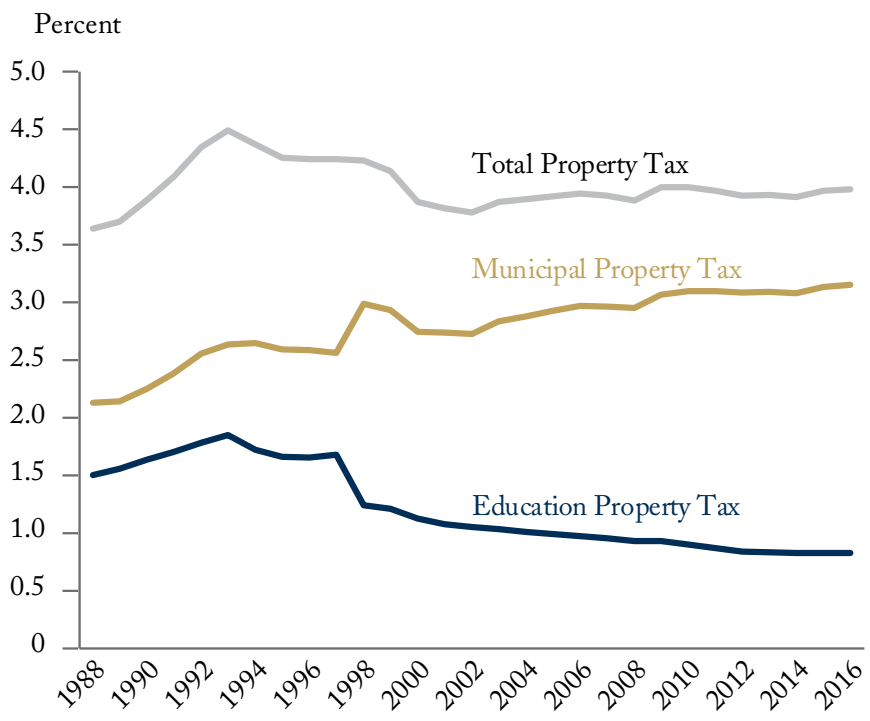

Note: Property taxes include business and residential taxes.

Source: Author's calculations from Statistics Canada Tables 385-0009; 385-0003; 385-0037; 3850036; 206-0011; and 326-0021.

money (see chapter 3). The solution is for provinces to step back entirely from property taxes and let municipal governments take up the tax room (Bird, Slack, and Tassonyi 2012).

Throughout much of the 1960s through to the 1990s, property taxes in Ontario were mostly devoted to local school boards, not municipal governments (Dahlby and McMillan 2018). Since then, property taxes (looking at both residential and business taxes) notionally dedicated to education have fallen as a share of total income across the country (figure 4.1). Although municipal property taxes have increased a small amount as a share of total income, total property taxes as a share of total income are still well below their peak in the 1990s. 
Property taxes are based on the assessed values of homes, not incomes. These assessment rules often limit how much a person's taxes can increase, even if property values climb. Let's focus on residential property taxes. As of 2015, the total assessed value of residential properties in cities in Canada's four largest provinces was $\$ 3.7$ trillion. Non-residential assessments add another trillion dollars to that total. In Ontario and British Columbia, the total value of property is around four times more than the annual value of production of the provincial economy. In Alberta and Quebec, property values are around two-and-a-half times the size of the entire economy of those provinces. In most Canadian provinces, residential property taxes have been falling as a share of this assessed value of homes. Since 2009, in British Columbia, Ontario, and Quebec, residential property taxes as a share of total property values have fallen (figure 4.2). Only in Alberta have taxes increased as a share of property values.

The burden of residential property taxes in both regards that matter - as a share of income and as a share of property value - has either stayed constant or fallen over much of the last decade. Why, then, are people complaining about property taxes? As we'll see, there are some features about the property tax that make it particularly visible. Such visibility is what makes it a good tax for cities to levy - at least from the perspective of taxpayers, but less so for the politicians collecting the money.

\section{Inelasticity of the Tax Base}

A common concern, which emerges more from politicians than from residents, is that property taxes don't increase substantially as the economy grows - that they are relatively "inelastic." However, the recent increase in property values has revealed such concerns to be misplaced. As Dahlby and McMillan (2014) show, the assessed value of properties in Alberta has increased by more than the value of incomes, which are what provincial and federal authorities tax via the income tax. Alberta cities have been better off fiscally 
Figure 4.2: Municipal Residential Taxes as Share of Assessed Values

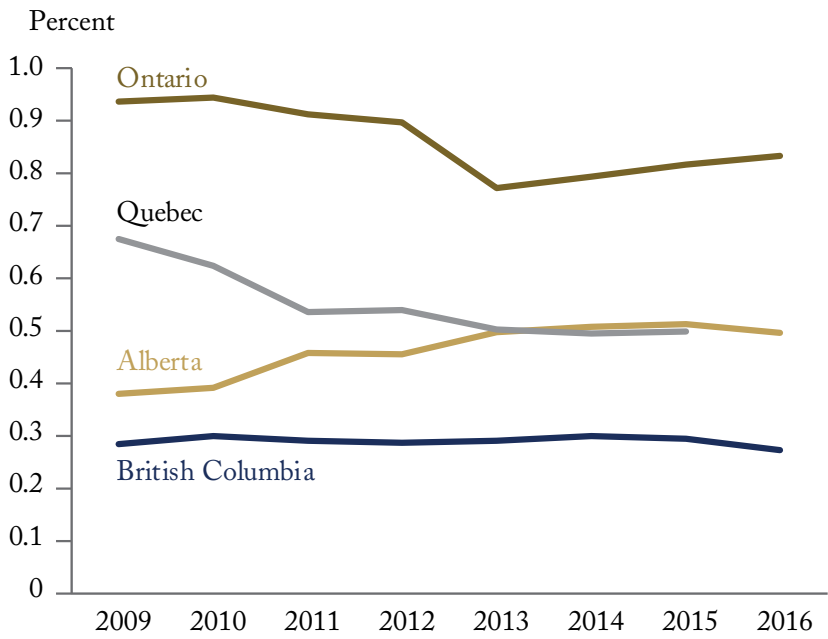

Note: Quebec 2016 data not available as of publication date.

Source: Compiled municipal financial statistics.

than the provincial government in maintaining revenues without increasing rates.

The concern over inelasticity hinges on two issues: the rate-setting willingness of politicians and the effectiveness of the property assessment system. Politicians may be less willing to increase property taxes than other kinds of taxes - such as income taxes or sales taxes - because property tax bills arrive in resident mail boxes with a louder thud than the slow drip of income taxes withheld on paycheques or the few dollars in sales taxes on receipts. It is a purely political issue, unrelated to economic elasticity and highly visible (Slack 2011). Politicians must make clear to their residents that they are spending their tax dollars efficiently.

The evidence from Ontario shows that most major Canadian cities fall far below the economic maximum they could, without driving away residents, collect by increasing rates on their residential 
property tax base (Bird, Slack, and Tassonyi 2012). These results were specific to the Greater Toronto Area, but they may be relevant to other Canadian cities that see a similar mix of residential and non-residential property taxes.

Canada's property tax system largely relies on market-based assessments that are quite advanced relative to the rest of the world. Although the details vary province by province, most residents pay property taxes based on the value assessment of their home in either the current or a recent year. In Germany, in comparison, property values were frozen in the 1960s in Western Germany (and in 1935 in Eastern Germany), and the only increase in property value that residents need to consider for tax purposes is based on an annual national increase regardless of how much the specific property increased (or decreased) in value. Austria is stuck in 1973, Belgium in 1975. Other countries, such as Greece or Poland, don't have the necessary data to calculate the value of a specific house, so collect the same total fee for all houses in an area (Slack and Bird 2015). England assigns houses to one of eight tax groups based on its value in 1991, and dwellings in each band pay the same amount. Even if a house itself changes - such as with an addition - it changes bands only when the house is sold.

Looking at all these international options for changing how we assess homes, it becomes clear that the current assessed value systems in Canada are a fairer and more transparent way of linking property values with how much home owners pay in tax. A market value system allows cities to collect some of the value of local infrastructure improvements (see below). Services such as parks, transit, and other inherently local benefits will result in higher home prices. A system of market-based assessment means that those who benefit from local services end up paying their fair share of the tax cost of supporting them.

Indeed, the stability of assessed values is a strong virtue of municipal finance and the property tax system. Unlike the tax base 
of the land transfer tax, the fact that Canadian cities in the four largest provinces have access to the largest possible base of asset values in the country - the more than $\$ 3.7$ trillion in assessed residential property values - means that city finances are independent of swings in the real-estate market.

\section{Is the Property Tax Regressive?}

The property tax bill for residents may not be in line with their incomes. For example, a senior citizen may have bought a house decades ago, and that property is now worth many times what the resident paid for it. However, because property taxes are based on the current value of the house, they have climbed well past what the resident could pay with only a retirement income. However, this problem relates to income rather than property taxes, and governments have tried to solve it through tax credits in the income tax system for seniors and low-income earners. Some cities, such as Toronto, have cancelled property tax increases for senior citizens with incomes below $\$ 40,000$ and home values worth less than $\$ 850,000$. Cities in British Columbia have extensive tax-deferment programs, allowing residents to defer some of their property taxes until they sell their homes.

From the perspective of matching those who pay for a service with those who benefit, these are not good policies. If a senior citizen resident is paying relatively little in property tax compared to someone down the street with a house of similar value, the senior citizen is underpaying for municipal services. Moreover, viewed over a lifetime of using municipal services, property taxes are neutral with respect to a person's income. Should the person with a high income today be receiving the subsidy later after retirement?

Subsidies to deal with perceived tax progressivity problems create deeper distortions. Property prices reflect the value society places on a resource. With rising prices in many cities, housing is a 
very valuable resource. Lower property taxes subsidize a resident to stay in a home that others value more highly and are better able to afford. Subsidies to lower property taxes for existing residents create an incentive for them to stay in their homes, perhaps keeping them from downsizing to something that would suit their needs better.

This impediment occurs because of the "capitalization effect." People who are thinking about buying a house know they will have to pay property taxes on the house they purchase. As property taxes go up, so will the future tax bills on their potential new house. They must factor this capitalization into their decision.

Subsidies to lower property taxes so that residents can stay in their existing homes create a gap in how a prospective buyer and the seller view the capitalization of property taxes on a particular property. The buyer will look at the full cost of taxes due and pay an amount for the property that reflects those future taxes (and future services). The seller, however, doesn't face those taxes because of provincial subsidies and views the house as having a higher net value. As with the land transfer tax, this disparity creates a gap between what buyers and sellers think is the fair market value (see chapter 3). Policies that attempt, from a single point in time, to introduce fairness into property taxes result in keeping housing out of the hands of young families that are hoping to buy bigger homes (İmrohoroğlu, Matoba, and Tüzel 2018). Looked at over a lifetime, residential property taxes are a fair way of financing municipal services.

The state of California has had a much more extensive system of reducing property tax increases, with revised assessments occurring only when the existing resident sold the property. Canadian cities should examine the results there before they extend their own deferrals on property taxes. This state policy, known as Proposition 13 for the amendment to the state constitution, resulted in people moving 30 percent less than they otherwise would have (Ferreira 2010). 
A better approach is an income-tested benefit that all residents can get, whether homeowners or renters, and which they can use toward their housing costs (see chapter 11). There's no need for society to subsidize property owners ahead of renters with a special income-tax credit on property tax or a property tax deferral. A credit that anyone in need can use for any kind of housing is a less economically distorting choice and a more efficient way of converting tax dollars into the kinds of housing people need.

\section{Land-Value Capture: How to Make Property Taxes Even Better}

Property taxes are the best revenue-raising tool for local governments - and they can be made even better. One of the problems with property tax as practised in much of Canada is that the tax rate applied to a single site applies to all real property on that site. The tax rate on land is the same as the tax rate on the structure built on it. Applying a tax rate on structures creates an economic problem: it discourages people from building the kind of house they would prefer, and businesses from building factories or offices that are best suited to their needs. A tax applied only on land doesn't have this downside. As the saying goes, "They aren't making any more of it." Changing the property tax to apply only to the value of land would mean the property tax would not discourage any kind of activity that should otherwise happen.

The two main obstacles to such a reform have been technical and, mostly, political. The technical problem is that it is not obvious how to separate the value of land from the value of buildings. Most transactions that set the baseline for assessment systems are of both land and structures. This issue is easily solvable in Canada, which has a fairly advanced property appraisal system based on estimation techniques. That means that assessors can get close to the value of a property even if it hasn't sold for many years. The same can be done for land. Indeed, British Columbia's assessment agency breaks out 
the value of land and property, so at least one province has the ability to move toward this smarter property tax right away.

The bigger impediment is political. As with any tax reform, some people would be better off while others would be worse off with the reform. In any such debate, the people who will be worse off tend to have the loudest voices - and the politicians tend to listen to them.

\section{How to Make Land-Value Capture a Reality}

There are two ways to enact such a reform. The first is to fully separate land and structures in a property tax system. This approach has the downside of being a wholesale property tax reform yet not being attached to any specific benefit. The other approach is to slightly modify an existing tax policy, the "Tax Increment Finance" (TIF), so it will act more like a land-value capture tax in specific areas near major infrastructure investments (as recommended by Found 2016). A TIF plan could be modified to apply only to the increase in value to nearby properties due to an investment such as a transit line. That would make it akin to a land tax, though it would only apply in parts of a city. Ontario allows cities to implement a TIF, and Calgary and Edmonton have TIFs in place now. Cities in Ontario use a section of the provincial Planning Acts and $\mathrm{BC}$ cities use something similar, which allows them to extract payments from developers after rezoning (more on this haphazard approach in chapter 11). However, these programs are only a start in the potential application of the idea.

The solution specifically for moving to a system of land-value capture is to pair such a change in taxes with improvements in local services. Policymakers should be clear that if tax reforms don't go ahead, then local infrastructure improvements won't either. Transit is a particularly good way to use a TIF applied to increased land values. There is clear evidence that transit investment increases the value of nearby residential properties. For example, both subway and 
light-rail lines built in London, England, increased the value of residential properties (Gibbons and Machin 2005). A TIF could capture some of the increase in property values that local residents received because they live near where a government built a transit line.

Cities could create a defined zone around a transit station, calling it the TIF zone. As a transit line is built, property values in the zone will increase faster than in other parts of the city. Under the current property assessment system, residents elsewhere would see a relative reduction in their property tax bills because of the higher increase in one part of the city. Under the TIF, property values would increase in the TIF zone, where residents would pay a full tax on the increase in their property values relative to the rate of change of properties elsewhere in the city. In other words, it would be a land tax.

Such a revised TIF would make sense for many Canadian cities. Calgary and Edmonton have a TIF plan in place for their downtown areas, and the municipal governments are investing in its improvement. However, these plans amount only to siphoning off property tax revenues from new developments in the TIF districts and earmarking that revenue for TIF purposes. However, those new properties create new demand for city services, leaving a hole in the budget for traditional services. A TIF that applied only to the value uplift would avoid this problem because the pre-transit station property taxes on existing homes would stay earmarked for traditional municipal services. Such a land-value capture TIF would amount to a combination of a user fee and a property tax. The higher tax that residents near a transit station would pay is akin to the value they get from being able to use the station. As Found (2016) showed in the case of a major transit line proposal for Toronto, known locally as SmartTrack, an uplift-based TIF has great potential to finance local projects. 
There will be many factors to consider in redesigning Canadian TIFs to replicate a land-value capture tax. How much should cities be allowed to collect? How does such a system work with strict zoning rules? How would appraisal work? How does the matter relate to ability to pay, and therefore to the previous issues on tax deferral programs? How volatile would such taxes be? Despite these challenges, the idea is worth exploring in Canada because land-value capture for public transit is not a radical idea. It has been used in a number of different countries with success.

\section{Land-Value Capture Around the World}

In Hong Kong the transit agency - which has since been privatized and is a publicly traded company - is an extensive real-estate developer. Its holdings are closely integrated to the transit operations, and its large rental income means that it no longer needs a subsidy from the local government to operate. Australia has a land tax, though it is generally limited to land that doesn't have an individual's own residence on it.

Montreal is taking a different approach, adopting the best ideas of a TIF as seen in Ontario or Alberta and turning them into a land-value capture tool. The regional transit agency is undertaking a major expansion of light rail throughout the region. One interesting aspect is that it is doing so with investment from the province's pension investment fund, which will operate the Réseau électrique métropolitain (REM) (see chapter 8). The key innovation in this funding is the plan to fund a portion of the payments to the operator, using tax revenues explicitly tied to the increase in property values. Cities across Canada should be watching the Montreal land-value tax example and look to build on it to finance their own transit expansion plans. 


\section{Why Politicians Should Stop Worrying and Learn to Love Residential Property Taxes}

The problems with residential property taxes have nothing to do with economics; rather, they are political. Reforms of the residential property tax should focus on how to deal with the political problems they face for acceptance by the public. Foremost would be explaining to taxpayers more about each province's - or each city's - specific property tax system. As Bird, Slack, and Tassonyi (2012) suggest, property tax bills should clearly present information such as the following points:

- how much of the local property tax falls on residents as opposed to businesses;

- how much of the property tax goes to municipal coffers as opposed to provinces;

- how each household's property value changed relative to other properties in the city or the province; and

- how the local government plans to spend property tax revenue and how it reaches that decision.

Property taxes are the best possible tax for local governments. They are suited to local governments so well that provinces in Canada should mostly get out of the property tax game and leave cities with the exclusive authority to collect property taxes. Economists such as Richard Bird, Enid Slack, and Almos Tassonyi have made this case for Ontario, just as Bev Dahlby and Mel McMillan have for Alberta. If the provinces vacated property taxes, the property tax bills would become more transparent. Cities would also have the ability to take up more of the tax room left by provinces to fund services as needed.

Unfortunately, it will be a long time before the provinces eliminate their property taxes. Alberta was set to collect about $\$ 2.4$ billion from provincial property taxes in 2018 , with around 
60 percent coming from residential property. Ontario budgeted to collect about $\$ 6$ billion in 2018 (with most coming from business property taxes). The simplest first step toward a solution is for both the provinces and the cities across Canada to commit to levying an equal rate on businesses and residents (see chapter 3). Next, the provinces and the cities should aim to lower business property taxes as much as possible to the level at which businesses pay only for the value of the services they receive, while recouping any lost revenues from the kinds of taxes that most match those who benefit from a service with those who pay. In other words, move the residential property tax system to something akin to a user fee system. Social services or other government spending such as education that have wide social benefits should be mostly paid by higher orders of government.

\section{User Fees}

To paraphrase Oliver Wendell Holmes, taxes are the cost of a functioning society. We as a nation have agreed that services such as police and fire protection, basic health and education, and a system of social supports are part of Canadian society. Many of those services are redistributive in nature. Health and social services are best paid for by income taxes or sales taxes that people with a higher income pay relatively more toward compared to the services they receive.

Municipal services are somewhat different. Many municipal costs are financed through property taxes - but higher taxes mean lower property prices (see above). A more efficient city that provides good service at a lower property tax cost will see otherwise higher property values. People who don't like the mix of taxes and spending in one city can go to another that better matches their ideal. What this means is that property taxes are akin to a user fee for city expenses in aggregate.

For other municipal services, there can be an even more precise matching of those who benefit from a service with those who 
pay. These are services that are most amenable to explicit user fees in which a local government sets a price for each user based on exactly what is used. There must be a clear nexus between the cost of providing the service and what a city charges users (Althaus and Tedds 2016). Just as with residential property taxes, the price of a service is clearly visible and transparent. User fees help municipal voters to make choices that are good for them and for society as a whole, but politicians tend to be wary because they provide one more tool whereby voters can hold them to account.

When the benefits of a service accrue to the buyer, the most efficient way for society to allocate who pays for what is through pricing. If municipal residents value a service the city provides at more than the price set by the city, they consume more of it. When such services are provided free of charge or paid for with other taxes, such as property taxes, residents end up using too much and wasting tax dollars.

We see this behaviour all around our cities. When it costs too little to throw out garbage, people create more waste than necessary. If parking is underpriced, everyone drives and it becomes harder to find a parking spot. Cities then lack the money from user fees to finance more landfills or bigger parking garages to meet the demand, and they turn to higher taxes to pay for the additional infrastructure. The better approach is to set user fees exactly at the cost of providing the service.

\section{User Fees in Ontario Cities}

As we saw from figures $3.1 \mathrm{a}$ and $3.1 \mathrm{~b}$, Ontario is fairly typical of Canadian provinces in the amount municipal residents pay in user fees to their cities. Residents in Alberta and British Columbia pay a little more; those in Quebec pay a little less. The largest single source of user fees for cities, taking Ontario as an example, is in water and waste services (where Ontario has the best data). In fact, since 2016, 
water and wastewater services have been financed fully by user fees (see chapter 11).

The other area of municipal services most reliant on user fees is waste collection (see figure 4.3). Ontario cities financed about onethird of total waste collection and disposal expenses with user fees. Cities across Canada collect user fees for waste in a number of ways: some charge residents and businesses a price per bag of waste they want removed; others charge people or businesses a fee to dispose of waste in municipally owned landfills (see Dewees 2002 for a comprehensive summary of waste pricing).

Municipalities are quickly increasing their reliance on user fees for waste services. Toronto, for example, has moved to fully finance its waste services by user fees. The evidence is also clear that smarter user fees for waste can cut down on the amount that goes to landfills. In cities that have made the move, waste pricing has reduced the total amount of garbage heading to landfills by up to 40 percent and increased the amount recycled sixfold (Kelleher, Robins, and Dixie 2005). Canadian cities should follow Toronto's lead on waste services and fully finance it with user fees, not tax dollars. That said, Toronto's user fees for waste collection do not provide the best model. The city charges residents an annual amount based on the size of the bin, regardless of whether it is full or empty. A better approach would be to pay for each bag collected, as is common in many other cities and for businesses in Toronto.

Cities rely on user fees to cover about 20 percent of costs in most other areas. For protective, general government, and health and social services, we should not expect user fees to cover the cost of provision. These services, if they are not redistributive in nature, are best paid for with property taxes. Social services should be supported by taxes that are progressive with the ability to pay. One contentious though small part of overall spending is municipal-owned golf courses, which barely cover their costs (Bula 2018). Their low 


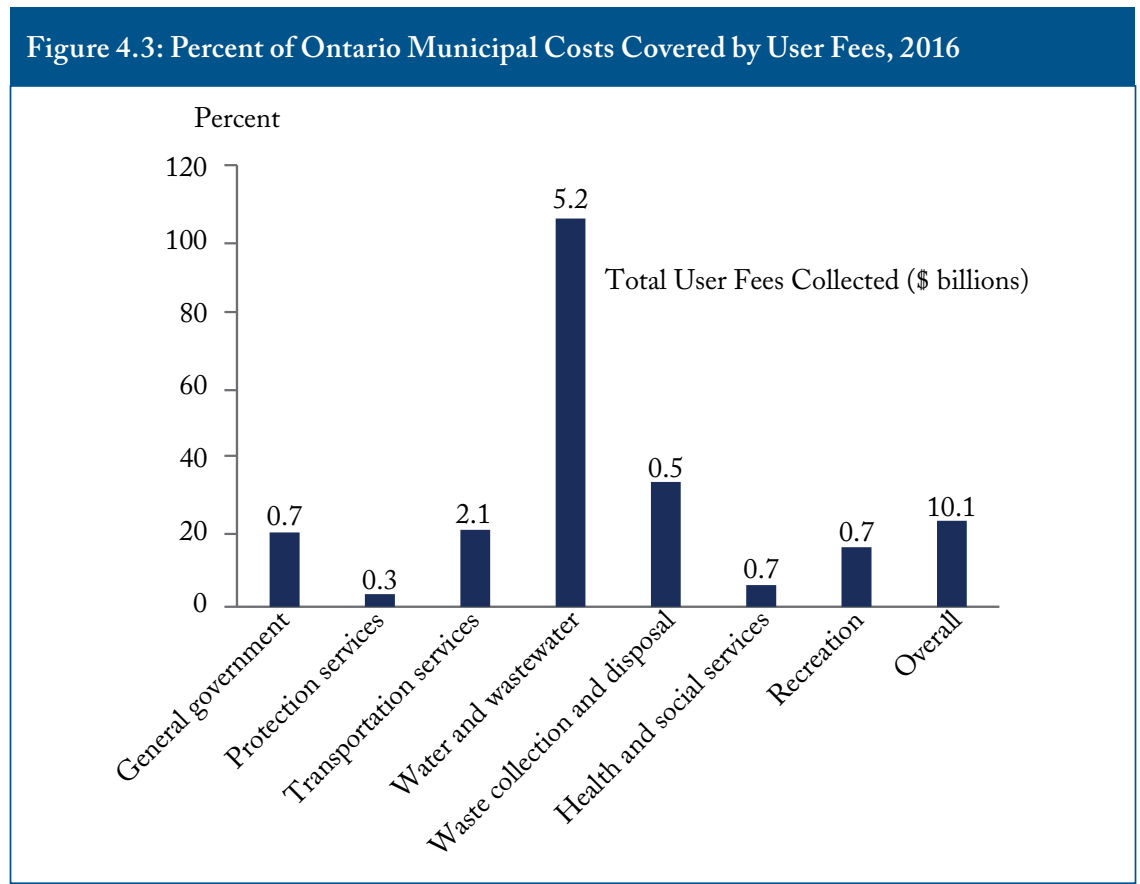

Source: Author's calculations from Ontario Financial Information Return.

fees subsidize golfers at the expense of all taxpayers, while the land they occupy has an opportunity cost because it is not being used for housing. The user fees for golfers should include the cost the city is forgoing by not using the land for other purposes. If users are not willing to pay that cost, then the land has better use.

\section{Getting the Price of Parking Right}

Roads and parking lots are among the most valuable assets owned by cities across Canada, and they should be managed better (see chapter 7). Let's consider user fees for parking. ${ }^{16}$ Cities should put in place better user fees for both metered on-street parking and for residential parking permits.

16 This section draws on a review of parking economics and citations from Dachis and Tsao (2016a, 2016b). 


\section{Improving Hourly Paid Parking}

The Toronto Parking Authority, which is a representative example, charges by the hour for on-street parking in Toronto's core commercial areas. Prices vary depending on the location of the parking space, ranging in increments from $\$ 1.50$ to $\$ 4.00$ per hour. These prices don't change based on actual demand. Demand for parking changes with location and time of day. Parking spots downtown should be more expensive during working hours than during offpeak hours.

Donald Shoup, the world's leading expert on parking, found in his popular 2011 book on parking that sixteen studies done over nearly a century show that 30 percent of the cars in congested downtown traffic were due to drivers searching for a parking spot. If parking spots were priced correctly, that change alone would help eliminate the surplus of cars on city streets during peak hours.

Cities could vary the price of parking to meet demand using an app instead of antiquated parking metres. Toronto has such an app, but it isn't using it to set prices dynamically based on demand. Cities should put a price on local street parking once streets exceed 85 percent parking occupancy. That price would rise or fall so that parking spots are available at all times. This system will also reduce congestion because people would no longer be cruising around for parking spaces.

Many US cities are using smarter pricing. Six months after the introduction of smart parking pricing, the amount of available parking increased by 10 percent in Los Angeles (Conduent 2017). Likewise in San Francisco, in areas that implemented smart parking, availability increased by 16 percent within two years (SF Park nd).

Better pricing can reduce the average price of parking. After the introduction of demand-dependent pricing in Los Angeles, prices fell in 60 percent of parking spots and increased in only 
27 percent (Siddiqui 2015). Similarly in San Francisco, the average price of parking decreased by 4 percent within the first two years of introducing demand-dependent pricing (SF Park nd).

Smarter pricing on parking can increase revenues too. Los Angeles collected 2 percent more in parking revenues after the introduction of smart parking, even while the average price of parking fell by more than 10 percent (Conduent 2017).

\section{Improving Residential Permit Parking}

Residential parking is a modern example of the classic economic problem of a shared resource. When left unregulated and unpriced, some drivers can't find a place to park. Many cities use time limits, say two hours, to keep spots open. After the time limit, a parking enforcement officer can ticket your car. But these rules are expensive to enforce. A better approach is to put a price on access to a parking spot. Currently, when cities do put a price on parking, they often dramatically underprice it - especially for residential parking permits. As of 2016, annual residential permits cost nothing in most of Calgary for the first two vehicles, $\$ 38$ in most of Vancouver, and at least $\$ 180$ in Toronto. Montreal permit prices vary by neighbourhood, from being free to $\$ 140$ per year. In large parts of these cities, there is a waiting list for residents to get access to residential permit parking - indicating that people are willing to pay more than the going price.

The issue is bubbling up in Canada's four largest cities because of the upstart car-sharing service "car2go." Members can pick up a car in one part of the city and drop it off in another. Other services, such as Zipcar, have dedicated parking spots for individual cars. Carsharing has a number of potential benefits. Studies have found that it boosts transit use and reduces the number of vehicles people need to own (private cars are parked 95 percent of the time) (Vancity 2018). 
Despite the boom in car-sharing services in Calgary and Vancouver (which has North America's largest car2go fleet), and its popularity in Montreal and Toronto, some residents and municipalities are pushing back. Residents in Calgary, for example, are unhappy about the blue and white cars taking up scarce residential parking space. In Toronto in 2015, car2go asked city officials to allow its users to park in areas where residents require permits to park. The city refused, but car2go went ahead anyway in 2016 and told its members to park illegally in residential permit areas and time-limited spots. The fines and the enforcement regularity weren't enough, at first, to deter car2go.

The solution is to charge one permit price for local residents, and another higher, variable price for non-resident cars, such as car2go. In January 2018, staff at the City of Toronto recommended just that. It would have set a floating parking permit at $\$ 1,500$, much higher than the current residential rate. The city estimated that such a parking permit would increase revenues for the city (Toronto 2018b). But City Council rejected it, concerned about parking for residents. The final proposal from council in April 2018 made many places in downtown Toronto off-limits for car2go street parking because they were over-subscribed by local residents (Toronto 2018c). Car2go found the model unworkable and cancelled its Toronto service the next month.

Why did council turn down such a revenue-raising option? People who own parking permits are also their voters. How can we keep them happy? The solution, according to Shoup (2011), is to have all parking revenues from a neighbourhood go back toward community improvements. This approach would entice voters and business improvement districts into wanting non-resident parking. Residents would also be guaranteed a parking spot on their street while seeing improvements to their neighbourhood. It's a win-win situation, thanks to better user pricing. 


\section{Smarter Cities Mean Smarter Taxes}

Residential property taxes are a fair, economically robust, transparent, and stable way to finance municipal governments. Policymakers may not like the annual process of setting property taxes and holding themselves to account to local taxpayers. For residents - as taxpayers and voters - property taxes they pay on the annual assessed value of the property are the best way to share the cost of municipal services fairly.

Residential property taxes can be improved. Land-value capture offers a solution for governments looking to finance new major infrastructure, such as transit, without discouraging new housing development. Nearby residents who own property near new transit stations see a major windfall in their property value when new stations open. Provincial and municipal property tax regimes would not need to change much to be able to capture some of this increase in value from a new transit investment. Many other municipal services, particularly waste and parking services, also have the potential to be financed more with user fees, rather than putting a large share of the cost burden on taxpayers.

Now that we've discussed how cities should - and shouldn't - raise money, let's look in Part Two at how they decide to spend that money. 



\section{PART TWO Municipal Operations \& Infrastructure}





\section{Chapter 5}

\section{If You Can't Fight City Hall, Fix It}

Often after heated debate, municipal governments use the taxes, grants, and user fees they collect to pay for police salaries, public transit, waste management, and many of the other key services that Canadians have come to expect. In Part Two, I turn to the way governments decide to spend money, what they spend the money on, and (most important) how they could make better spending decisions. In the process, I'll look at annual expenses, such as protective services (police and fire) and waste collection (chapter 6), as well as longer-term infrastructure spending (chapters 7 and 8). To begin, though, I will focus first on how the governance of municipal councils determines local spending, and then on how regional decision-making can address regional spillovers.

Local councillors in most of Canada act in many ways like one-person political parties. Individual council members represent their constituents, but outside the bounds of organized political parties. Aside from Quebec and British Columbia, they are not part of a broader political party seeking to control a majority of the seats on a local council to pursue a broad agenda. The way municipal councils 
operate has parallels to one of the oldest models in the social sciences - the tragedy of the commons - where, in a shared-resource situation, individuals acting independently in their own self-interest behave contrary to the common good. We should consider an expanded role for political parties in municipalities as one way to address the governance problems inherent in municipal councils.

Another major economic problem is that municipal governments do not necessarily cover the entire region in which residents live, work, and play. A resident may live and pay taxes in one city, work and ride the transit services in another city, and use the parks and recreation facilities of yet another nearby municipality. This regional spillover problem means that people often use services that are subsidized by residents in other areas. It's one justification why senior governments should fund local service infrastructure instead of leaving these developments entirely to cities (see chapter 3). Another approach is to contain the spillovers by creating a regional body that captures all the benefits. I will look for examples of solving this regional riddle both within Canada, specifically in British Columbia, and abroad, such as in London, England. These models reconcile the desire to upload services to higher-order governments while preserving local control.

\section{Local Governance}

In a ground-breaking C.D. Howe Institute Benefactor's Lecture from 2001, Ken McKenzie tackled the consequences of potential major democratic reform - a core issue in recent Canadian debates. Many of his insights can be applied to how local governments operate as well:

Similar to provincial and federal elections, Canadian 
local-government elections in most of the country use the first-pastthe-post system. ${ }^{17}$

- In most provinces, with the exception of British Columbia and Quebec, political parties are not used at the local level to distinguish the policy positions of candidates.

- Some cities use ward-based voting, akin to federal and provincial ridings for council members. Others use at-large voting for councils.

- Unlike senior-level governments, the local government budget process is debated and decided in the open and very publicly.

- Across Canadian municipalities, councils and mayors are elected for a fixed term. That means there can never be a vote of non-confidence at the municipal level.

\section{How Political Institutions Affect Expenditures}

What are the key consequences on expenditures from different political institutions? Let's compare municipal systems to those at the provincial and federal level - though in a more cursory way than expert political scientists, especially Zack Taylor (2016), have done.

\section{Political Fragmentation from the Lack of Municipal Parties}

Under a first-past-the-post electoral system, the candidate with the most votes wins, regardless of whether the total represents a majority of the votes cast. At the provincial and federal levels, the first-pastthe-post systems tend to be biased toward giving the party with the most votes a disproportionately high share of seats. They also create

17 The Province of Ontario granted cities the option to conduct their municipal elections using ranked ballots, starting in 2018. In October, London, Ontario, will be the first Canadian government to hold an election in this manner. 
less political fragmentation than other systems that use proportional representation, which reflects the wider range of voters' preferences.

Empirical studies reviewed by McKenzie in 2001 and subsequent work by many others have shown that more fragmentation in political decision-making increases government spending. ${ }^{18}$ Why is that? Here's an analogy that McKenzie uses: take a basic resource, such as fish in the ocean. An individual fisher looks to pull as many fish from the ocean as possible. He does not consider the effect his haul has on others. As a result, all together, the fishers will overfish, depleting the fishery. One solution is for the government to grant monopoly rights to a single owner or to allocate licences to individual fishers, who can then bargain among themselves. The bargaining becomes harder as more fishers try to trade licences.

Government budgets are akin to a common resource. Politicians at any level face similar incentives to draw on the common tax funding pool. As the number of groups at a legislative council increases, as happens with proportional representation, the ability for them to bargain diminishes.

Local councillors in most of Canada are elected using the first-pass-the-post-system, which creates strong majorities when political parties operate. However, local political parties exist only in British Columbia and Quebec. Going back to our analogy, the ability of fishers to trade their fishing quota diminishes as their numbers increase, and they can't create a system for efficient barter. Something similar might be happening with local politicians elected without any political party affiliation, making it harder for local government councillors to come to agreements on government decision-making in the context of limited tax resources.

18 See, for example, Persson, Roland, and Tabellini (2007) and Persson and Tabellini (2004). 
The important point here is that this presumption follows after we apply McKenzie's thinking to municipal governance. However, many more complications emerge from political parties. For one thing, as Moore (2017) argues, parties may result in less local representation, partly because some decisions made at the party level would need to be taken in the interests of the municipality as a whole, rather than those of the local communities. Further, local government political parties may not be as organized as their provincial cousins, as has been the case in Montreal, according to Mévellec and Tremblay (2013). Municipal-level political parties are not purely altruistic operations, seeking to reconcile the spending priorities of constituents. Clarkson (1971) found that, to prevent competition, they seek to discourage new political entrants.

Much can be said about the benefits of local ward-based voting versus at-large voting, but most of it is beyond the scope of this book. Do councils with at-large voting act mainly in the interest of their ward, at the expense of the city as a whole? The political science literature on this theme presents a wide range of mixed evidence, making it difficult to provide definitive answers about the consequence of ward-based or at-large voting. ${ }^{19}$

\section{Governance of the Budget Process}

Ostensibly for protecting sensitive financial information that could sway markets, the contents of federal and provincial government policies are a secret until they are released as a final proposal. Legislators, both those in opposition and backbench government members, do not get access to budget plans until the day the budget is released. Once the budget is presented, a vote is taken for it to go on for consideration by a committee. Any successful vote to defeat the progress of the budget bill would result in the fall of the government, followed

19 See Koop and Kramer (2016), Southwick (1997), and Langbein, Crewson, and Brasher (1996) for good examples. 
by fresh elections. As a result, voting is highly disciplined along party lines.

Municipal budgets have no such secrecy. The mayor, all the councillors, and the public see the same presentation from staff at the beginning of the budget process. Individual councillors often present motions amending the budget to fit their specific interests. Municipal council terms are set, regardless of the outcome of key votes. Individual councillors do not face the voters if they appear to ask for more money in each budget and then vote against it.

Budget debates are held behind closed doors federally and provincially. Federal and provincial finance ministers can withhold information on the fiscal room available, even to others within their government, arguing that no money is available to finance new projects. The reality often tends to be quite different, as documented by numerous C.D. Howe Institute studies: between 2002 and 2018, provincial revenues frequently came in well above the original forecasts and were much more than spending overruns (see Robson and Omran 2018).

How might a different process change the dynamics of decision-making at the municipal level? Municipal budget hearings are often marathon sessions, with presentations by one group after another asking for more spending. They may well be armed with the knowledge that their program is on the chopping block, creating an incentive for those appearing before municipal council to have their own ideas of how to spend every one of those dollars. Individual councillors may do the same.

This debate happens in public, and it may lead to a perception that cities are short of funding. This open process may also lead to more spending. Given that these differences in municipal budgeting are consistent across Canada - cities in all provinces have open and public budget debates - it is difficult to determine exactly how 
a change in the process might affect the working of governance at this level. However, if political parties imposed some discipline on the budget process by standardizing some decisions that councillors might make, the results would be interesting to analyse.

\section{Is the Time Right for Local Government Political Parties?}

Political parties give voters more information about the views of a specific candidate, providing them with a better short-cut than name recognition as they decide how to vote (Moore 2017). To demonstrate the role of political parties versus ward-based or at-large voting, we need only look to what happened in Calgary and Edmonton, for example, after reform to their electoral system in the 1960s. Before these reforms, Vancouver, Edmonton, and Calgary had similar council turnover rates. Council turnover measures the ability of voters to change the direction of their government by electing new representatives. As Sayers and Lucas (2017) have shown, council turnover rates in these cities took very different directions after Calgary and Edmonton started changing their electoral system. Although other factors may have been at play, councillors in those cities saw an upswing in their ability to hold onto their seats once parties were abolished and votes became ward by ward. Voters with less information about candidates tended to stay with those they knew by name alone. In party-voting Vancouver, in contrast, fewer councillors held onto their seats.

Political parties have their faults, to be sure. However, a more serious look at the case for expanding the role of political parties at the local level would be worthwhile.

\section{Regional Governance}

Many of the challenges that urban regions face spill over the boundaries of municipal governments. Too often, the default approach provincial governments have chosen to solve regional problems has imposed some form of amalgamation on smaller governments. 
Although the provinces often tout amalgamation as a cost-savings measure, the initial results usually indicate the opposite - the cost of municipal services increases (Slack and Bird 2013; Found 2012). Labour costs meet the highest wage of the previous constituent cities, nullifying savings. However, more recent research from Timothy Cobban (2017) shows that administration costs - a component of overall municipal costs - did fall with amalgamation.

Canadians need a different model to solve region-wide issues and to think beyond the binary debate on whether to amalgamate or not. A solution led by cities themselves is the ideal forum for dealing with key regional governance challenges facing municipalities in a number of provinces. There are good examples both abroad and within Canada, particularly in British Columbia, in which two-tier models have been very successful (Slack and Bird 2013). Local governments in the Toronto area should have a stronger role in setting regional transit policy, and municipalities in Alberta need to solve emerging problems of extending municipal services to rural areas (see below). Readers grappling with different regional governance problems elsewhere in Canada and for different services will see a similarity in the causes and solutions they can apply to their hometowns.

\section{Going Nowhere Fast: Fixing Transit Governance in Toronto}

Originally created in 2007, Metrolinx started with a board made up of local government officials to create a regional transit plan for the Greater Toronto and Hamilton area. Two years later, Metrolinx expanded to become the GO Transit operator. The province then removed the local government officials from the Metrolinx board and appointed board members from the public.

Metrolinx now faces many difficult decisions - in particular, how best to integrate regional and local transit fares. Effective January 2018, the provincial government implemented a $\$ 1.50$ 
discount for those who transfer from the GO train to the Toronto Transit Commission (TTC) system. However, this discount is only a stop-gap measure: the issue of people transferring from one system to another will be substantially greater once the Regional Express Rail plan is in place. Other problems include which projects to prioritize, who should operate new lines, and how to pay for it all.

How can the region overcome local opposition to the necessary changes while still acting in the regional interest?

\section{Striking the Balance of Accountability and Efficiency}

Some parts of the disparate transit operators across the Greater Toronto Area must be consolidated into a single entity. For example, a single planning agency could integrate fares across the region, fixing the current practice of bus lines stopping at municipal borders and requiring passengers to pay a separate fare to continue their journey into the next municipality's system. Such an agency would also have more expertise in integrating transit plans with various municipal-specific zoning policies in order to improve density around transit stations - a key source of potential government revenue (see chapter 4).

The core of any reform focuses on the board of directors of Metrolinx. The current board lacks the accountability that municipal politicians would have if they failed to deliver on transit promises. Furthermore, the current joint responsibility between the province and municipalities in the region confuses voters about who holds responsibility for spending their tax dollars wisely and whom to punish (or reward) at the voting booth for the performance of their transit system. At present it is easy for local politicians to pass blame around, especially to the unelected transit board.

The Toronto Region Board of Trade (2018) has proposed an innovative idea to solve this problem: Superlinx. This new body would replace Metrolinx and become responsible for all operations 
and planning for regional transportation. It would also take on all municipal debt related to transit and receive from the province any existing transfer revenues. More controversially, the proposed Superlinx would levy a charge akin to a tax on municipalities - an amount equivalent to each city's current tax-supported subsidy. The province would appoint at least half the directors, who would be independent and have transit-specific expertise or represent specific regional groups such as transit riders or businesses. Local governments would have a small share of the seats, supplemented by an advisory body made up of regional mayors and regional chairs.

This plan has many merits. If it goes ahead, it would break the log jam of regional transit fiefdoms. However, a number of potential roadblocks may make the plan unpalatable to many municipalities and it may never go into effect.

A single large transit agency will likely excel at executing large regional plans, but it will probably be less successful at getting the local details right - for example, the best corner of a road on which to place a bus stop and accommodate the seniors' residence nearby. Those engaged in debates over regional integration need to remember the important and inherently local part of public transit.

Indeed, the majority of transit trips that people take are local - within their municipality. ${ }^{20}$ In my view, we should not let the regional integration problems dominate what is a still fundamentally a local service. Local politicians, who are accountable to residents of a neighbourhood every few years, best bridge the divide between regional and local interests.

Furthermore, creating an independent agency that has the ability to set taxes indirectly through a tax on municipal budgets, but

20 Tricia Wood (2017), using the latest census data, found that 80 percent of commuters who live in Toronto also work in Toronto. Indeed, the majority of commuters in most Greater Toronto Area municipalities live and work in the same city. 
without input from local voting taxpayers on their performance, creates a democratic problem. Finally, as the Toronto region has learned, because the economies of scale are difficult to realize, higher costs are one of the many downsides of forced amalgamation (Found 2012).

\section{Creating a Municipal-Led Regional Transit Body}

How about a more bottom-up approach to creating a single regional transit agency? In this alternative model, the emphasis on the province, rather than cities, driving board appointments would be reversed. The province should restore the role of municipal governments on the board of Metrolinx, akin to what existed before 2009, alongside a group of provincially appointed representatives, akin to the Superlinx proposal. To remedy the problem of a board composed only of politicians, a small number of experts would also be appointed. The reconstituted board should create subsidiary operations with subject-matter expertise that report to the board - for example, in planning and capital investment, bus and transit delivery, heavy rail, and regional highway development.

Any regional body would need to recognize the unique status of the TTC and Metrolinx. The City of Toronto has $\$ 5.5$ billion in net transit assets, after originally investing $\$ 10.3$ billion (see figure 5.1). ${ }^{21}$ The rest of Ontario's municipalities have less than half that amount, with the largest chunk being in Ottawa. Metrolinx has more in assets than all the province's municipal transit systems combined. It also has much more up-to-date transit, as measured by the current net book value after deducting accumulated amortization, and even more coming with projects currently under construction.

21 These terms originate in accrual accounting (see chapter 2). The current net book value of transit assets is what remains of useable value of the asset after deducting amortization. 


\section{Figure 5.1: Ontario Municipal and Metrolinx Transit Asset Values, 2015}

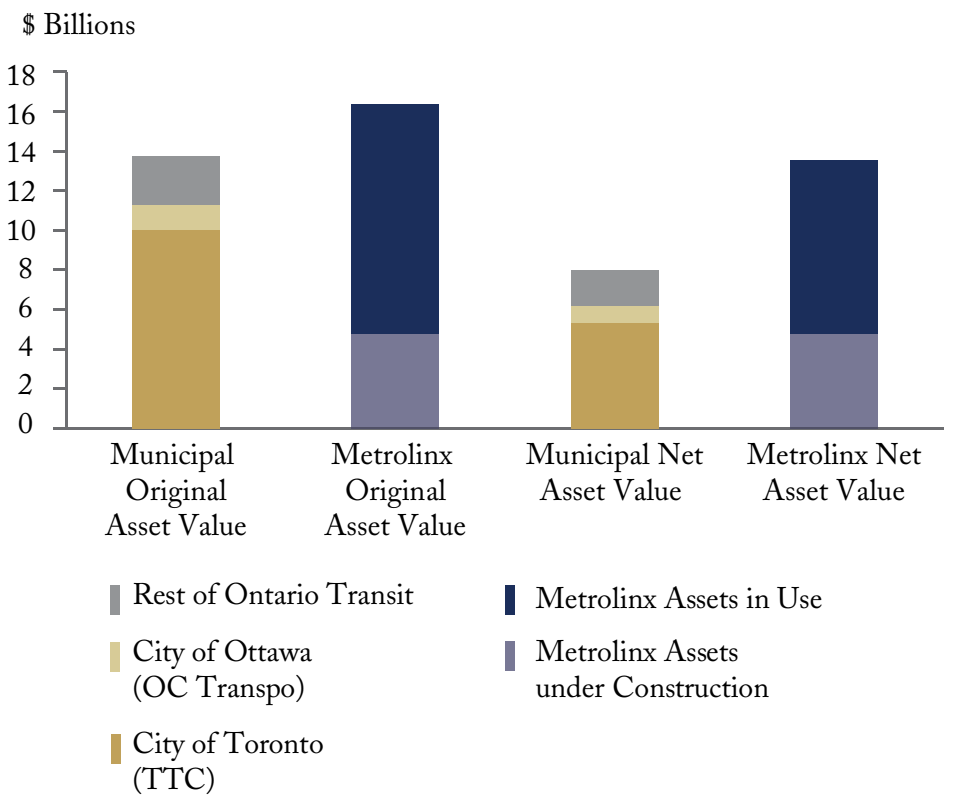

Source: Author's calculations from Metrolinx and from Ontario Municipal Affairs.

In total, Metrolinx and the TTC own almost 90 percent of transit assets in Ontario. As a result, it is not practical (or realistic) for Toronto to have the same number of seats as other municipalities on the board of a reconstituted Metrolinx. The TTC should become a jointly owned subsidiary of Metrolinx and the city. That would provide the best of both worlds: municipal councillors would still have the ability to direct their representatives on the board of the TTC to reflect local needs, while the TTC would also directly respond to the regionally mandated Metrolinx.

Some of the largest current transit investments would fit this model nicely. For example, the new Eglington Crosstown LRT line will be owned by Metrolinx. However, it has signed a 10-year 
agreement with the TTC to operate it. The TTC is one of North America's best transit operators, winning the award of transit agency of the year in 2017.22 However, the TTC does not have the authority to plan for new projects (such as subway expansions) or to operate buses outside Toronto's borders. It also has a poor track record in building new projects: the subway expansion to York Region resulted in delays and cost overruns, and the renovation of the historic Union Station in downtown Toronto has gone well over budget. ${ }^{23}$

If the TTC operated under contract to Metrolinx, it would be able to manage its routes just as it does today. It could also expand its operations outside Toronto if that were deemed the most efficient way to proceed. The contracting model is a good way to keep critical assets in public hands while seeking out the best operator to do the job (see chapter 6).

There are several successful examples of this model both in Canada and abroad - for example, Transport for London (TFL), which operates transit in the United Kingdom's largest city. TFL demonstrates one way to combine a board that represents riders with the area-specific expertise to oversee operations. TFL's board is chaired by the mayor of London and includes diverse representation, from workers, disability advisers, and industry experts. ${ }^{24} \mathrm{TFL}$ has a plethora of subsidiary companies, ranging from property managers to rail-line-specific operators to financial service providers. Each subsidiary has its own board of directors to oversee its distinct service - composed often of different people from those on the broader TFL board. The overlap of some board members enables the integration of various services. ${ }^{25}$ The TFL contracts out the delivery of many of its

22 https://www.thestar.com/news/city_hall/2017/06/26/ttc-named-best-public-transit-agency-in-north-america.html

$23 \mathrm{http} / /$ www.cbc.ca/news/canada/toronto/spadina-subway-cost-1.3404472

$24 \mathrm{https:/tfl.gov.uk/corporate/about-tfl/how-we-work/corporate-governance/}$ board-members

25 https://tfl.gov.uk/corporate/about-tfl/how-we-work/corporate-governance/ subsidiary-companies 
bus routes to private operators, resulting in some reduction in costs (see chapter 6).

In Vancouver, the regional transit coordination body, Translink, was established pursuant to provincial legislation. The board of Translink is appointed by the Mayor's Council, made up of representatives from each of the region's 21 municipalities. Translink has many subsidiary companies that operate transit services under contract.

Zac Spicer and Adam Found argued in a 2016 C.D. Howe Institute Commentary that the B.C.-wide model of regional districts, represented by Translink and the Mayor's Council, is worth emulating across the rest of Canada. In making their case, they drew a distinction between a "regional authority" and a "regional coordinator." Ontario's upper-tier municipalities are a kind of regional authority, acting as a fully separate level of government. That model works well in delivering fully regional services but, unfortunately, creates an additional bureaucratic layer. Voters are also confused about which politician is responsible for which service, thereby reducing the accountability of policymakers for the services they are providing.

The regional coordinator model, in contrast, creates a council-like governance body made up of local government representatives. As Spicer and Found argue, regional districts directed by local governments - not appointed by provincial policymakers - act as agents for their lower-tier (member) municipalities. It's a selective and bottom-up approach to creating a regional authority. Unlike amalgamation (which is a permanent solution to all problems), as service needs change, member municipal governments can direct the regional districts to offer new services, as but one example. New member municipalities can be invited to join or to take on a larger role. In addition, cities can opt in or out, service by service, as they see fit and, if they wish, supplement region-wide services, as West Vancouver chooses to do for transit. 
Such a regional governance model will not be perfect immediately: it will take local governments some time to decide what services to delegate collectively to their new regional body and which ones to keep themselves. They will also need to work with their provinces to set the rules for these bodies. In sum, if cities can learn what made regional governance work in places such as Vancouver, a voluntary regional body governed by cities can contain the various spillovers among municipalities, promote coordination, and retain accountability to a single local elected government.

\section{Bridging the Urban-Rural Divide in Alberta}

Toronto has the problem of too many local governments with overlapping, but not coordinated, transit responsibility, while municipalities in Alberta have insufficient overlapping responsibility. Local governments there have distinct borders rather than counties or regional municipalities overlapping smaller, local governments.

Many regional municipal and county governments in Alberta are rural and have few residents in their taxing jurisdiction; their main source of property tax revenues is oil and gas properties. Workers who service these wells live in urban municipalities and pay property tax to their local governments. However, as they travel to rural areas to work, they use services - such as fire or police that are not fully financed by user fees - provided by the rural area governments.

To offset the costs of services provided to non-residents, governments set disproportionately high taxes on oil and gas properties (Dahlby and Conger 2015). In a study released in 2018, I compared the total property tax cost that oil and gas producers would pay in western Canadian provinces compared to similar ones in the United States. Specifically, I looked at a producer in the County of Grande Prairie - the epicentre of the latest oil and gas boom in Alberta. Municipal property taxes on non-residential properties are 


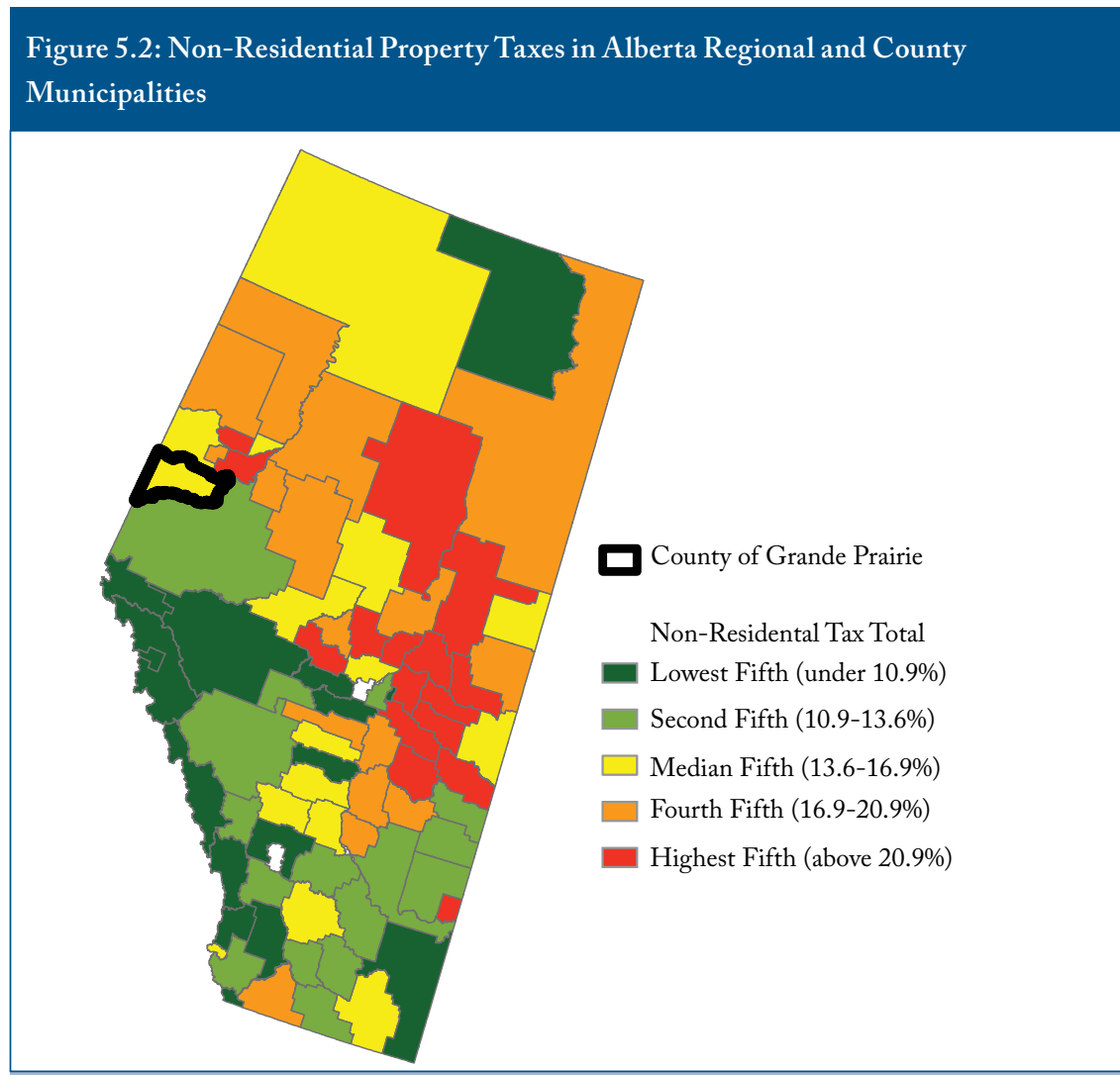

Source: Dachis 2018a.

about $\$ 15$ per $\$ 1,000$ of assessed value in the County of Grande Prairie. Property taxes there were average relative to tax rates in other regional and county governments (Figure 5.2). In many parts of Alberta, the ratio of business taxes to residential tax rates is more than five times. It is nearly 18 times in the Fort McMurray area, and more than 25 times in the county with the highest non-residential tax rate. Over the life of an oil and gas well, a producer in Grande Prairie would pay around $\$ 60,000$ in property taxes in discounted present value terms (see Dachis 2018a for details on this calculation). 
These high taxes are a major competitiveness cost to energy producers, similar to the problems caused by non-residential property taxes (see chapter 3). Property taxes are the major driver of competitiveness differences among the western Canadian provinces and U.S. states, such as North Dakota and Pennsylvania - which do not levy property taxes and are now two of the main places competing for oil and gas investment. In some cases, the taxes have become so high a cost for energy producers in Alberta that their property tax arrears are causing them to declare bankruptcy. In addition to the economic cost, these companies leave behind disused wells that cause major environmental harm and risks, such as leaks or explosions, to the local population (see Dachis, Shaffer, and Thivierge [2017] for a measure of the extent of this problem). ${ }^{26}$

Beyond typical property taxes, Alberta municipalities can also levy taxes on the value of machinery and equipment (a direct tax on capital) and a one-time tax on the depth of a well - a distinct municipal excise tax. How bad is this problem? As we saw in chapter 3, large cities are over-taxing businesses. Urbanized municipalities in Alberta collected around $\$ 700$ per capita in residential taxes, and a little less than that in non-residential taxes. The problem is much worse in rural Alberta. For this chapter, I have combined all these taxes into a single total of non-residential and residential property taxes collected by Alberta municipalities in 2016. In that year, regional and county municipal governments collected approximately $\$ 3,000$ per capita in non-residential property taxes (Figure 5.3). In comparison, they collected slightly more than $\$ 600$ per capita in residential property taxes.

Obviously, municipal governments need revenues to finance local services from which oil and gas companies benefit - for example,

26 One recent bankruptcy was expressly due to municipal tax costs, leaving thousands of wells to be cleaned up. See http://calgaryherald.com/business/energy/ oil-firm-ceasing-operations-leaving-thousands-of-untended-alberta-wells 


\section{Figure 5.3: Property Tax in Alberta Municipalities, 2016}

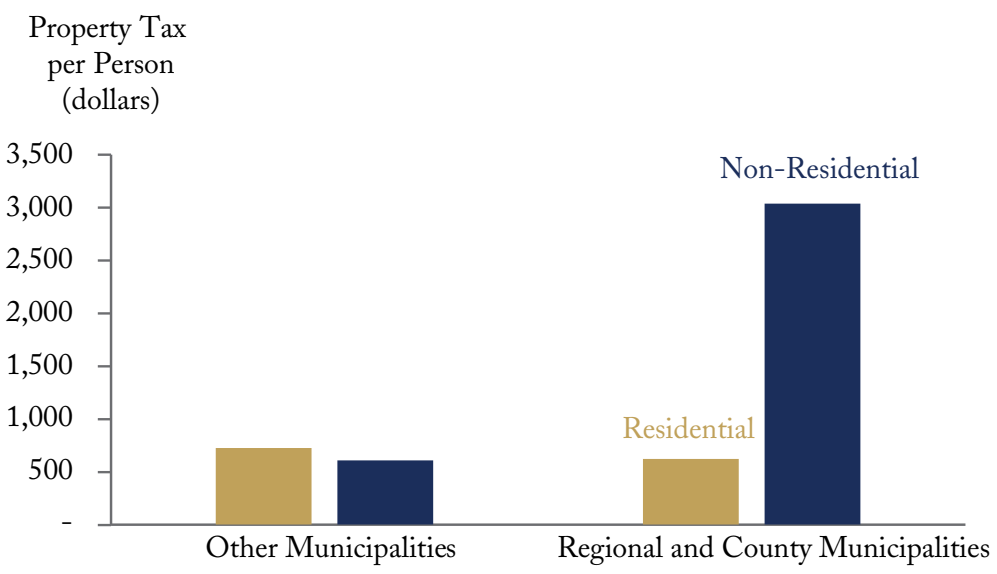

Source: Author's calculations from Alberta municipal financial statistics.

the roads companies use to reach well sites. Alberta's Well Drilling Equipment Tax, which uses depth of well as a proxy for the weight of equipment heading to a site (Dahlby and Conger 2015), is meant to cover the considerable damage caused by the heavy trucks that companies use to bring equipment to the well sites. It is a rather blunt (and therefore ineffective) instrument, and municipalities should instead charge tolls based on the damage done by these heavy vehicles.

A broader and therefore more effective solution is a change in municipal governance to address other expenses stemming from health, water utilities, and general urban costs that affect businesses and residents across municipal borders. Urban and rural municipalities should enter into service-sharing agreements, so that services for workers who live and pay tax elsewhere, and must be provided in rural areas, are partly paid for by residential taxes in urban jurisdictions (Spicer and Found 2016). The result would be lower taxes in 
rural areas and better matching of those who benefit from government services with those who pay for them.

A cooperative regional model in which individual cities elect to take part in a special-purpose body that consolidates the activities of a group of utilities or other services is most likely to lead to savings (Spicer and Found 2016). One example of this model is Aquaterra in Grand Prairie. Aquaterra, which is owned by both the City of Grand Prairie and the broader regional government and a nearby smaller town, operates the combined water services for them all.

\section{Solving Collective Action Problems at the Local and Regional Level}

Governance is not just a political problem but an economic one as well. Poorly designed institutions create the wrong incentives for local officials to get the tax and spending mix right. These problems occur on the day-to-day basis of municipal voting and, at the regional level, on big questions of how best to design transit systems or deliver water to households across a multitude of cities. Local governments have a few models they can look to as they try to get the right mix of accountability and expertise for addressing regional problems: the British Columbia regional district, for example, or Transport for London's operating structure.

As we saw earlier, the debate over local transit governance in the Greater Toronto Area has been raging for decades. ${ }^{27}$ Several proposals have been made for reforming Metrolinx, the regional transit agency, mainly with the intent of entrusting it with both local and region-wide transit services. Meanwhile, in Alberta, rural municipalities have been charging businesses - particularly oil and gas companies - high business property taxes because they have few residents to tax. Businesses end up paying for the services, such as roads,

27 For example, the Toronto Star called for merging the TTC and GO Transit in the 1980s. See https://munkschool.utoronto.ca/imfg/uploads/197/crossing boundaries scott sams.pdf 
which residents from nearby communities use. The best solution to both these regional governance problems is not to force neighbouring governments to amalgamate or to order that they hand over their assets to a region-wide body over which they have no control. Rather, it is a bottom-up approach in which municipal governments invest their own powers into a regional body they govern.

How best to achieve this change? If more municipal politicians advertised themselves as part of an organized political group, they might have more ability to address some of the core governance problems facing cities. The fracturing effects of loose coalitions have always been the downside of proportional voting systems, which were meant to alleviate issues created by a first-past-the-post electoral system. The first-past-the-post system created strong governments, but at the expense of candidates being elected who did not necessarily represent the majority of voters in a given riding. Cities (and provinces that set the rules for municipal governments) which don't already have political parties at the local level should consider whether they would actually make sense.

With the right incentives to take a close look at spending, cities can tackle the core spending issue at local government: to keep a lid on municipal labour costs. 


\section{Chapter 6}

\section{How Cities Can Deliver Better Services at a Lower Cost}

In Canada, there are major differences in how municipalities decide to spend taxpayer dollars and what they spend money on. For example, cities in Ontario and Alberta spend nearly double per capita the amount that cities in Quebec and British Columbia do. Across the country, labour costs are the key driver of how much local governments spend. Through collective bargaining, cities negotiate regularly with workers such as police, firefighters, transit operators, and administrative staff to determine wages, benefits, and services. If these negotiations break down, the resulting work stoppage can be a costly disruption to many of the key services provided by municipal governments.

In bargaining impasses, governments at all levels have taken steps such as banning strikes outright, mandating arbitration, or ordering striking workers back to work. Such measures have unintended consequences - they increase other types of labour disruption, raise wage costs, and fail to address the root cause of collective bargaining problems in the sector: the lack of competition in providing municipal services. 
Canadians do not like monopolies in the private sector. Governments have myriad laws and regulations to prevent them from forming and, if they do, to break them up. The solution for Canadian cities to insulate themselves from the harms of work stoppages, reduce costs, and improve service quality is to avoid public monopolies and, instead, rely more on competition for contracted services.

There is an important distinction between contracting and privatization. Many critics - particularly unions that stand to benefit from public monopolies - claim that using contracts for waste services results in privatization and fewer jobs for municipal workers, but that is not necessarily the case. Around the world, when cities allow municipal employees to bid for contracts alongside private contractors, municipal employees have provided the best value for money in the majority of cases. Indeed, contracting often works best when outright privatization or selling an asset is not the best option. Using private investment to help build new municipal infrastructure is a separate topic (see chapter 8).

\section{Municipal Services Across Canada}

How much does your municipal government spend? What do municipal governments spend your money on? What areas have seen the largest growth? The answer depends on the province (figures 6.1a and 6.1b). For example, in 2015, Ontario and Alberta municipalities spent a little over $\$ 3,000$ per person, while municipalities in British Columbia and Quebec spent less than $\$ 2,500$ per person. The mix of spending is also very different across provinces. In contrast to municipalities in Ontario, municipal governments in Alberta, Quebec, and British Columbia are more focused on the delivery of services from which all residents benefit - such as water, protection, and transportation - than on social services (figure 6.1a). Protective services - mainly police and fire - cost taxpayers about $\$ 500$ per capita across the country. Water and wastewater services are comparable as well, 


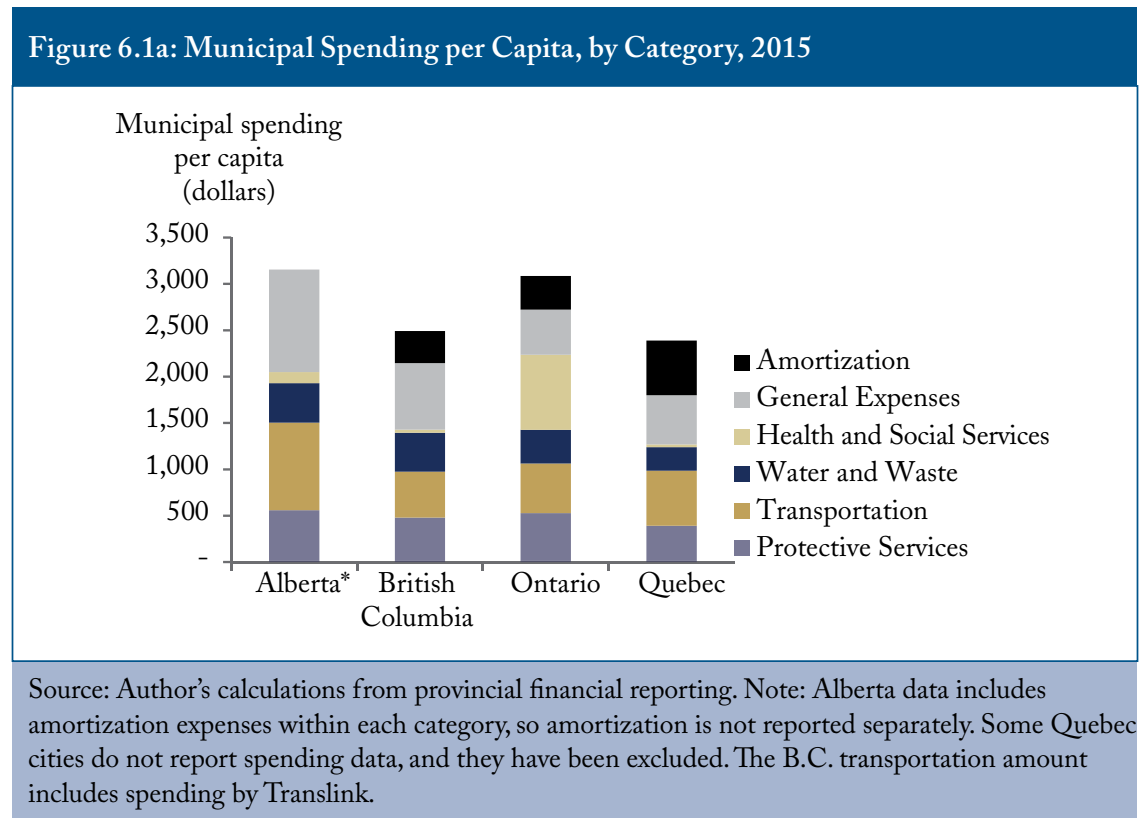

Figure 6.1b: Municipal Spending per Capita, by Category, 2009-16

2016

Dollars

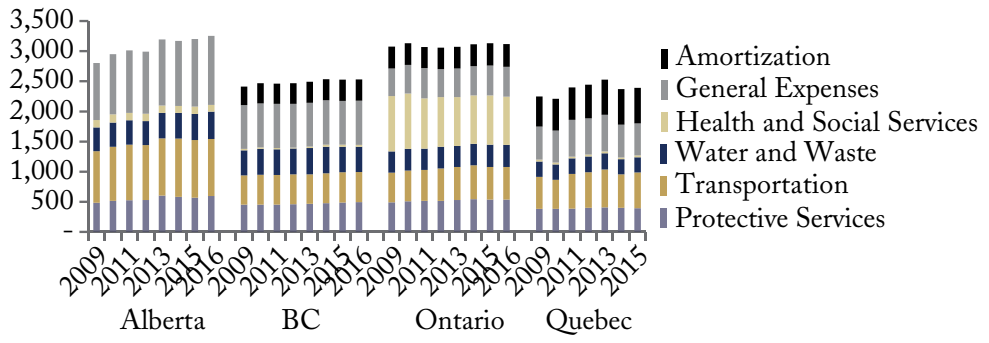

Note: Alberta data includes amortization expenses within each category, so amortization is not reported separately. Some Quebec cities do not report spending data, and they have been excluded. The 2016 data is not available for Quebec cities. The B.C. transportation amount includes spending by Translink. Source: Author's calculations from provincial financial reporting. 


\section{Figure 6.2: Ontario Direct Municipal Expenses, by Category, 2016}

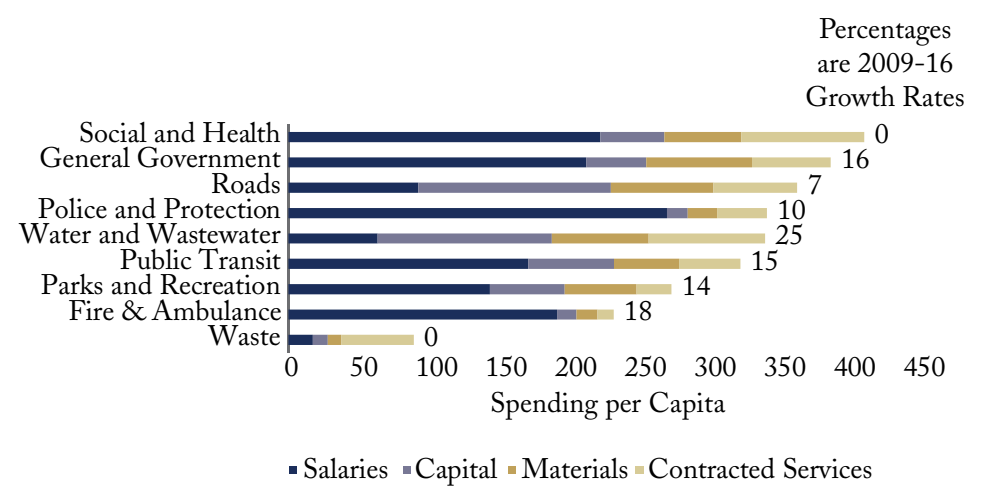

Note: The growth is expressed in real 2016 dollar terms.

Source: Author's calculations from Ontario Financial Information Return.

though lower in Quebec. Transportation expenses are somewhat higher in Alberta compared to those in other provinces.

Spending per capita has not grown as fast as revenue per capita (see chapter 3). The fastest growth in expenses per capita has been in Alberta, where they grew by 16 percent from 2009 to 2016. In the rest of the country, spending per capita grew by less than 6 percent (figure 6.1b). Ontario cities have seen their social service obligations shrink as the provincial government has uploaded some of the services previously delivered by municipal governments.

\section{Municipal Spending in Ontario}

As we have already seen, Ontario cities have the most detail available on their total spending. All cities in the province are required to report in a standardized provincial form, the Financial Information Return. This database is a treasure trove of municipal spending data: it provides information on how much each municipal government spent in each department on many broad categories of spending, including wages, materials, and contracted services (figure 6.2). 
In 2016, the year with the most recent available data, Ontario cities spent a total of $\$ 42.5$ billion. The most surprising element of direct municipal spending might be how much cities spend on health, social services, and housing. However, much of this spending is covered by provincial transfers as Ontario cities deliver the programs.

The other surprise is how little cities spend on waste services - now the smallest share among major municipal spending categories. Furthermore, over half of that total is spent on contracted services, meaning that only a fraction of total waste spending is on municipal staff.

Wages for municipal employees make up about half of total spending. Although wages represent about 80 percent of total spending for police, fire, and ambulance services, they are less than 25 percent of total spending in areas such as waste, roads, and water and wastewater services. In roads and water services, capital expenses - the amount set aside for amortization - make up about 40 percent of total costs.

Overall spending growth per household has increased by 12 percent since 2009 . This increase is largely attributable to water and wastewater and to labour-intensive services such as police, fire, and transportation. Contracted expenses in public transit have been the largest growing individual expense component in Ontario. The component with the least growth has been capital costs for public transit: total per capita municipal expenses on amortization in public transit fell from 2009 to 2016.

\section{The Main Cost Driver for Cities: Municipal Workers}

Municipal employee costs - wages and benefits - make up about 50 percent of all municipal spending, so it is essential to keep labour costs under control in order to determine the overall cost of government and, therefore, tax rates. 
Labour costs relate directly to outcomes in collective bargaining between municipalities and unions. Although there are no data I am aware of that provide the unionization rates of municipal employees, the rate of public-sector workers more generally has stayed constant at about 75 percent for the last 20 years. In contrast, the private-sector unionization rate has been falling for decades and is currently around 16 percent of employees. In many of the core municipal services in which labour expenses are a large share of total costs - police, fire, and public transit most notably - unionization rates are anecdotally high.

\section{Municipal Wages and Strikes: The Data}

Let's take a look at the base hourly wage of unionized employees covered by collective bargaining agreements for units with more than 500 workers. The base wage is the only wage-level data the Government of Canada collects from collective bargaining agreements. These data cover all collective bargaining agreements for units with 500 or more workers from the late 1970s to 2016. A separate dataset covers all work stoppages in Canada. Each dataset provides the industry the workers are in, such as public transit, protective services, or general municipal administration.

Since 2004, unionized Canadian municipal employees have had historically faster base wage growth than both unionized public-sector employees elsewhere and unionized private-sector employees, particularly since 2014 (figure 6.3). The main municipal employee groups with quickly rising wages have been police and firefighters, at least in Ontario (Cote and Fenn 2014). They have consistently seen wages increase at over 3 percent - sometimes 4 percent - from 2002 through 2012. These protective services often fall into a special labour relations process that results in upward pressure on labour costs for cities (see below). 
Figure 6.3: Wage Growth in the Municipal, Public, and Private Sectors, 1997-2017

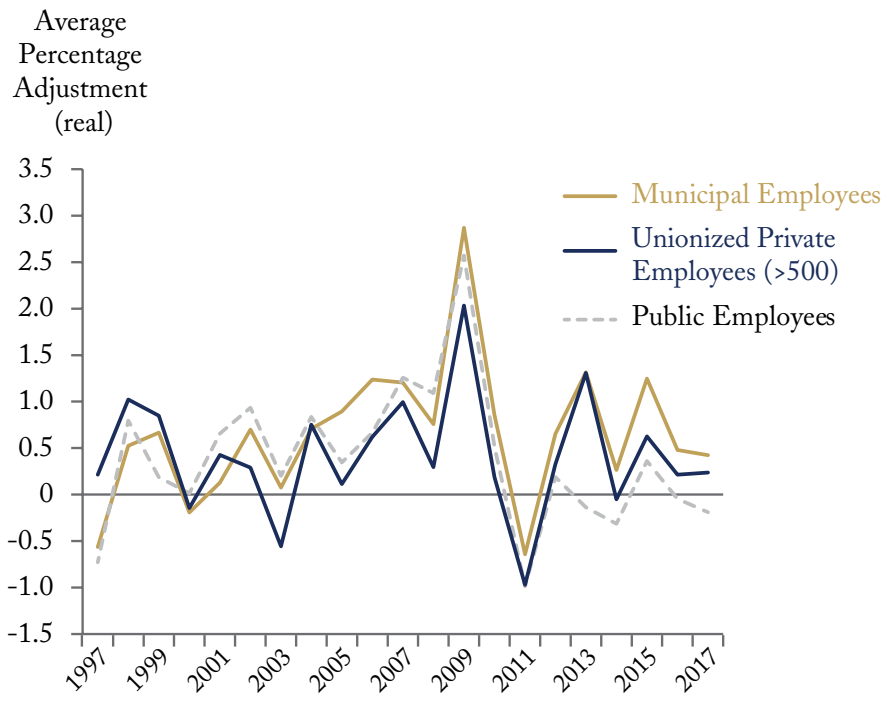

Source: Author's calculations from Employment and Social Development Canada (ESDC) and Statistics Canada data. Note: Wages are six-month moving average.

\section{Work Stoppages at Municipal Governments}

Nearly every strike by public employees receives considerable public attention. Strikes in some municipal services can endanger public safety; others have significant economic costs. In most cases, the hardships faced by those who use strike-affected services are significant. Generally speaking, the strikes that grab public attention are those affecting police, public transit, and garbage collection. These key services are difficult to replace, at least in the short run. Striking unionized city workers also means closed pools and municipal daycare centres, cancelled recreational programs, and delayed building permits.

Some of the most notable strikes in recent Canadian history include those by municipal employees that halted garbage collection: 
in Regina in 2005, Vancouver in 2007, Windsor in 2009, and Toronto - twice since 2000. There have also been a number of transit strikes (as public transit workers are usually covered under their own collective bargaining agreements): Toronto in 2008, Ottawa in 2009, Kelowna in 2016, and Gatineau in 2017. For every strike that actually occurs, many more contract negotiations go to the breaking point, with residents frantically arranging alternative transportation, child care, or garbage disposal.

Despite the ever-present threat of municipal employee strikes, the incidence of strikes has actually been declining. Since 1979, there have been 100 strikes by municipal workers - including at least seven major labour disruptions in Toronto and its amalgamated municipalities, five in Montreal, and three in Vancouver. On average, between 1979 and 2000 there were three per year; since 2000, the number has fallen to around two per year.

\section{The High Cost of Banning Strikes}

No politician wants to be seen as responsible for garbage not being picked up or for residents being late for work because transit is shut down. And nobody - workers or politicians - wants emergency services to be affected by a labour disruption if a life-or-death situation arises. As a result, Canadian governments have pre-emptively passed essential services legislation, removing or limiting the right to strike for some services (police and fire) or pushing through legislation forcing workers back to work after a lengthy strike. Provinces have the sole authority over labour relations for almost all municipal employees. Provincial sector-specific legislation, such as provincial acts that apply only to police, firefighters, healthcare workers, or provincial employees, usually determines public-sector labour relations.

Provincial governments often remove the right to strike for some types of workers by requiring labour disputes to be resolved by mandatory arbitration, effectively banning strikes. In another 
approach, governments attempt to moderate the potential effects of a strike by designating certain services as "essential," so they cannot be fully withdrawn, although labour stoppages may still occur. Workers are allowed to strike, but some portion among them is legally obligated to continue providing designated services (as determined before a strike) during the job action. Governments also sometimes intervene with "back-to-work" legislation to force an end to a dispute. These orders may compel employees to accept the most recent offer from the employer or to seek compulsory arbitration.

\section{The Unintended Consequence of Banning and Ending Strikes}

The diversity of Canadian provinces provides a natural experiment to analyze the effect of labour legislation on outcomes such as wages, employment, investment, and the likelihood of strikes. When a province amends its public-sector labour legislation, we can compare the outcomes to those in other provinces that did not institute the change. For example, in 2011 Ontario removed the right to strike for transit workers. In contrast, transit workers in Montreal are covered by the essential services designation. Elsewhere in Canada, transit workers usually have the full right to strike.

Articles by Dachis and Hebdon (2010) and by Campolieti, Hebdon, and Dachis (2014) use detailed data on every major Canadian public-sector bargaining and contract outcome from 1978 to 2008 . To assess the effect of the legislation, we authors used regression analyses to estimate its effect on the probability of a work stoppage occurring, on wages, and on the length of work stoppages when they occur.

Not surprisingly, we found that banning strikes and mandatory arbitration reduce the probability of a strike occurring. However, these measures also make it less likely that the parties will reach a collective bargaining agreement on their own without relying on an arbitrator. Hebdon and Mazerolle (2003) found that mandatory 
arbitration led to an increase in employer-employee impasses at the bargaining table as high as 21 percent of the time relative to workers with the right to strike. They also found that while strike-ban legislation is probably successful in reducing the likelihood of strikes, it increases the likelihood of other types of disputes, such as work-torule situations or work slowdowns (see also Hebdon and Stern 2003).

As for wages, banning strikes and mandatory arbitration lead to about a 2 percent increase in wages relative to workers with the right to strike. There are numerous reasons why mandatory arbitration might lead to higher wages: first, third-party arbitrators might place little weight on employers' concerns for wage restraint; second, because arbitrators looking to follow other benchmarks of wage agreements often consider the precedent set by similarly situated parties, settlements and awards can reinforce each other. Thus, in an economic downturn, arbitrated settlements might be slow to reflect lowered wage and inflation expectations or demands for major changes in work practices. In contrast, negotiated agreements are more likely to reflect changes in economic conditions as they occur.

There isn't much cities can do to improve the arbitration system because it is controlled by provincial policies. One set of ideas for reform of the Ontario arbitration system would put more onus on arbitrators to account for economic factors in their decisions, as opposed to their current practice of often dismissing such evidence, and to create greater accountability and independence in arbitrator assignments (see Chaykowski and Hickey 2012).

Essential services designations have the opposite effect, reducing employees' wages by about 2 percent and leading to no increase in the frequency and length of strikes. At first glance, this outcome is somewhat surprising: the continuation of basic services makes work stoppages less politically costly to employers and less economically costly to unions and their members. However, the essential services designation model reduces the bargaining power of 
workers, removing their power to withhold services from the public. At the same time, it gives municipalities the ability to bargain from a strong position, thereby lowering cost pressures.

\section{Municipal Contracting: Ensuring Services and Lowering Costs}

This labour situation may seem discouraging for cities. Labour costs are the largest, and growing, share of most services. Efforts to negotiate major cost savings often result in lengthy and disruptive labour stoppages or roadblocks put up by arbitrators. Further, the legislation that determines how cities negotiate with their workers is written by the province. What can cities do to keep service standards high but find cost savings? The answer is simple: contract out certain key municipal services, such as transit, water, wastewater, and solid waste management.

These services not only affect the day-to-day lives of citizens but are also the most amenable to contracting arrangements. Other services, such as snow removal and the operation and maintenance of recreation or daycare facilities, can also commonly be provided by contract. Contracting offers cities the ability to offer a service while simultaneously seeking the lowest-cost means of providing it and reducing the risk of labour disruptions.

The evidence shows that contracting saves money for cities around the world and in Canada. We will now look at the latest data on contracting in Ontario waste services. Previous work by Harry Kitchen (1992) found substantial savings in Ontario contracted transit services, from more efficient use of vehicles by private operators and from better value from drivers. Studies done of U.S. cities more recently found cost savings of between 6 (Iseki 2010) and 14 percent (Nicosia 2001), on average, from contracting bus services.

\section{How Contracting Works}

Contracting is common in many areas, ranging from water to waste 
to transit, and is quite different from privatization. Although there are many kinds of infrastructure or services that cities should no longer provide, contracting is the better option in many core municipal services (see chapter 8). In England, Transport for London, for example, put out tenders for contractor companies to operate individual or groups of routes (see chapter 5). Costs fell and passenger numbers grew as London maintained an integrated network and a seamless passenger experience (Savage 1993). This network can occur only where there is one overarching planning authority. Further, unless that single authority is a well-regulated private provider, municipal or regional governments are best placed to be the authority.

Competition motivates firms to keep prices low or to improve service for a given price. However, contracting in municipal services entails competition for access to the market itself. Once a firm obtains the contract, it is the only provider for the service for the duration and coverage area of the contract. In granting that exclusive right, municipalities need to be careful to define terms that encourage high-quality service. The contract also should reflect the inherent limitations associated with the inability to foresee and cover every eventuality, provide for the enforcement of its terms, and spell out the cost savings, quality of service, and transitions plans for current employees.

\section{Getting Contracting Right}

Cities should be careful in designing contracts with private providers. Governments ought not to hand over the keys to the city to any one private contractor - or to any one union. Replacing a public monopoly with a private monopoly would do no good. A municipality should hesitate to enter into a contract that involves assets that cannot be reused by other contractors or redeployed by the same contractor in another municipality. In contrast, services that use assets that can be used by multiple municipalities are good candidates for contracting 
out so long as service performance can be measured (Hart and Moore 1988).

Rather than specifying how services must be provided, contracts should specify standards of outcomes, such as the frequency of service, number of customer complaints to be tolerated, and other clearly definable goals that municipal staff, not just the contractor, can measure (see Walls 2003). For example, designating the use of particular vehicles or types of technology reduces opportunities for innovation by contractors.

Contracts raise the potential for anti-competitive behaviour by private operators, leading to higher costs over time for municipalities. Governments can become complacent about their contracting practices, defaulting to the same providers - and, over time, eroding cost savings. For example, privatization in areas of Spain with little competition resulted in progressively declining savings from contracting (Bel and Costas 2006); in the Netherlands, the cost savings from contracting out were substantial at first, but collusion among entrenched private contractors led, over time, to reduced cost savings (Dijkgraaf and Gradus 2007).

Economic theory suggests that the likelihood of collusion can be reduced by increasing the number of market participants and bidders on contracts. As the number of firms bidding for a contract increases, it becomes harder to maintain an implicit or explicit agreement to keep prices high, as the gains to an individual member of remaining in the cartel are reduced. The good news is that the Canadian waste services industry looks competitive. For example, in 2009, Peel Region (a suburban area outside Toronto) put out a request for proposal for its waste services contract. A total of 27 firms expressed an interest in the contract, and nine companies put in bids. A study of Canadian contracting from the 1990s found that waste contracts with at least five bidders had costs that were 29 percent lower per household than contracts with only one or two bidders, and that 79 percent of municipal waste contracts put out to tender 
received at least three bids (McDavid 2000, 2001). An analysis of London, UK, bus contracts found a similar pattern: costs were lowest where there were more than two bidders (Amaral, Saussier, and Yvrande-Billon 2006).

One way to encourage competition and a diversity of bidders is to split contracts - into large areas on which major operators may bid, and smaller districts where contractors of different sizes can be competitive with one another. However, the need for economies of scale means making a tradeoff between competition and the most cost-effective size of operation. Similarly, the contract duration must strike a balance between being long enough to permit a contractor to recoup its investment in capital, but short enough that a contractor does not have a lengthy monopoly on the market. The City of Ottawa, for example, tenders waste contracts for six-year periods (Dachis 2010). For city-specific assets, such as public transit lines or disposal sites, municipalities should maintain ownership and contract out staff operations.

The contract should also have a contingency plan to ensure that services are provided as normal during strike, bankruptcy, or other pressing circumstances. If there is no pool of potential service providers for unexpected disruptions, municipalities that lack sufficient employees who could step in risk leaving citizens without services. A well-designed contract would have a clear procedure for continuing services. Municipalities can also require that the private provider have a collective agreement with its employees which covers the duration of the service contract (see Dachis 2010).

\section{Why Contracting Is Not the Same as Privatization}

The key to better service is not necessarily private operation but an environment that encourages both public and private providers to innovate by improving service quality relative to costs. In a system called managed competition, public employees bid alongside private contractors for municipal service contracts. Municipal employees have the opportunity to show that they can best perform the services. In both the United 
Kingdom and the United States, public employee unions have won between 70 percent and 90 percent of the openly tendered contracts (Segal, Ifelayo, and Pescheck 2004; Bel and Warner 2008). A more recent analysis conducted by the City of Toronto found that in-house public-sector workers won 75 percent of the competitions between the private sector and in-house staff in various North American cities.

Many current municipal labour contracts make it difficult and expensive for municipal workers to be laid off. Workers who cannot be cost-effectively laid off or retrained for other municipal departments could form a public-work crew that could compete alongside private contractors. Jalette and Warrian (2002) found that, in 1998, approximately half the municipal government collective agreements did allow for contracting of services, up from less than one-third in 1986. However, in 2001, and for a broader range of collective agreements than those in municipal governments, approximately half the collective agreements and employees covered by all types of collective agreements did not permit contracting out if it resulted in a loss of work hours or jobs. Hebdon (2006) finds that among local government employees who were affected by contracting in New York state between 1990 and 2000, less than 5 percent were laid off, 36 percent were retrained for other jobs in the same government, 23 percent moved to the private firm, and nearly one-third of employees saw no change. Municipalities concerned with preserving jobs could create contracts that would give municipal employees the right of first refusal on jobs offered by private contractors or provide other incentives for the private contractors to hire displaced workers.

\section{The Cost Savings from Contracting: A Case Study in Waste Services}

Municipal waste services make an excellent case study for contracting: this task has a long history of being contracted out, and the data collected on these services demonstrate that contracts can reduce costs. Waste services can be broken down into three stages: collection of solid waste from households and businesses; recycling (collection 
and processing) of plastics, paper, electronic waste, industrial and construction waste, organic materials, and other materials; and disposal of non-recycled products at landfills or incinerators or their use in waste-to-energy facilities. Disposal covers a wide range of activities, from trucking waste to final sites to the operation of those sites.

In most of Canada, municipalities are responsible for waste services. In areas with two sub-provincial tiers of government such as a regional, metropolitan, or county government along with a municipal government - the responsibility often lies with the higher-level municipality. Many municipalities also employ user-pay systems, in which the cost of waste services to users is based on the amount of waste they produce (see chapter 4).

A 2004 survey found that 69 percent of Canadian cities and towns contracted out at least some disposal services, and 85 percent contracted out at least some residential and commercial waste collection; in other cities, waste services are entirely privatized - the municipality has no role in their provision. Surprisingly, perhaps, Canadian municipalities are more likely than their American counterparts to contract out waste services (Hebdon and Jalette 2008).

In all major cities in Canada except Calgary and Vancouver, private contractors are responsible for at least a portion of the collection and recycling of waste from single-family residential areas. Municipalities often delineate geographic areas, such as neighbourhoods, within their borders for which potential contractors bid to supply services. For example, Winnipeg contracts out collection based on quadrants of the city. Toronto has contracted out garbage collection in only half the city (see below).

While economies of scale often make it cost effective for a single contractor to perform multiple stages, a wide range of ownership and operation models for landfills and other final disposal sites is available. Many municipalities own and operate their own landfill 
facilities; in other cases, the municipality owns the site but contracts out its operation.

\section{The Evidence of Cost Savings}

A wide range of examples of contracting waste services in Canada has been studied. The evidence shows conclusively that contracting reduces the cost of waste services. In a 1997 survey of 279 Canadian cities, 59 percent relied exclusively on contractors to collect waste, 13 percent had a mixed public-private arrangement, and 25 percent relied exclusively on public provision (McDavid 2000, 2001). The survey concluded that, for a variety of reasons, private solid waste contractors were 20 percent less costly to municipalities than public workforces: private contractors had newer vehicle fleets, greater vehicle capacity, fewer workers per truck, and (on average) serviced one-third more households per collection crew. This result suggested that private contractors provided higher capital investment and productivity.

In a survey of Ontario waste providers, Dewees et al. (1993) found that, for private contractors, hourly wage and benefit costs were 30 percent lower than those for public employees and total labour costs were 40 percent lower. The number of waste pickups per route and the number of routes completed by private contractors were double those by public employees. Moreover, public employees took substantially more sick days per year (14) than did private contractor employees (2).

In a detailed study of the Ontario municipal waste contracting experience from 2000 through 2008, I found that costs per household for all waste services were lowest when 100 percent of the municipality's waste services were provided by private contractors (Dachis 2010). Partial contracting, however, has not been successfully used in Ontario cities: costs per household for diversion and collection services were highest when municipalities contracted out 
between 40 and 50 percent of services, compared to when they did not contract out any services.

Approximately 20 percent of municipalities in Ontario had contracts with other municipalities for the provision of diversion or disposal services, and 10 percent had contracts for collection services - most of them with an upper-tier municipality. Many municipalities jointly use the same waste disposal site if the efficient scale of operation is above what a single municipality requires; similarly, one particular municipality's recycling or collection services might prove to be the most cost-efficient provider in a wider area.

For waste disposal and diversion services, it does not matter if they are contracted out to other municipalities or to private contractors. The costs savings emerge simply from the contracting process, and cost savings are independent of which party earns the contract. Cost savings from the contracting process are 36 percent in disposal services and 23 percent in diversion services.

For collection, the story is different. When collection services are contracted out to private providers, municipalities derive cost savings of 24 percent; however, they derive little cost savings from contracting out to other municipalities. Thus, contracting in collection services through 2008 appeared to save money in the Ontario context only when private contractors were used.

\section{Case Study: Waste Contracting in Ontario Cities}

Most Canadian studies on the cost savings and service improvement from waste contracting were published several years ago. I will now update one of my studies, using the latest evidence relating to contracting in waste services (see Dachis 2010).

\section{How Contracting Reduced Costs in Ontario Cities}

Ontario municipalities collectively spent about $\$ 1.2$ billion on waste services in 2016, over $\$ 700$ million of which was on contracted services. To look at the effect of using contracted services, in place 
of municipal employees, I first measure the extent of each municipality's reliance on contracting by calculating the percentage of its costs that relate to contracted services. For example, if a municipality reports that its only waste service expense is contracted services, I report it as having 100 percent contracting; conversely, I assume that a municipality that does not report on contracted expenses has zero contracting.

Municipalities could also have higher costs owing to specific local factors, such as landfills or transfer stations in remote areas. Large, dense municipalities will likely have operating structures and costs that differ from those of small, less dense rural areas, making direct comparisons more difficult. I look at the data using the Ontario Financial Information Return (FIR) data from 2009 to 2016, and I control for characteristics of municipalities that do not change much over time, such as average density or size. This approach shows, over an eight-year period, how much costs per household changed in relation to how much of the municipality's waste budget was contracted out.

Across 362 Ontario municipalities, those with 100 percent contracting have, on average, 32 percent lower cost per person compared to municipalities with zero percent contracting (table 6.1). Dissecting further by stages, I find that the largest cost reduction comes from waste collection, in which there is an average of 49 percent lower cost per person for municipalities with 100 percent contracting. In disposal services, there are no apparent savings from contracting: indeed, contracting out disposal services is often associated with slightly higher costs. The savings from recycling contracting are minor, at about 16 percent, and not statistically significant.

The extent of cost savings also varies by the share of waste services a municipality has contracted out. There may, for instance, be substantial set-up costs of writing and enforcing a contract, meaning that contracting out only a small share of services may cost more 


\begin{tabular}{|c|c|c|c|c|c|}
\hline \multicolumn{6}{|c|}{ Overall Waste Services } \\
\hline \multicolumn{6}{|c|}{ Costs per Person with $100 \%$ Contracted Services Relative to No Contracting } \\
\hline \multicolumn{6}{|c|}{$-32.4 \%$} \\
\hline \multicolumn{2}{|c|}{ Total Observations } & 5,282 & \multicolumn{2}{|c|}{ Number of Cities } & 362 \\
\hline \multicolumn{6}{|c|}{ By Service Type - Cost Change per Person } \\
\hline \multicolumn{2}{|c|}{ Collection } & \multicolumn{2}{|c|}{ Disposal } & \multicolumn{2}{|c|}{ Recycling } \\
\hline \multicolumn{2}{|c|}{$-48.7 \%$} & \multicolumn{2}{|c|}{$17.7 \% *$} & \multicolumn{2}{|c|}{$-16.3 \%$} \\
\hline Observations & Cities & Observations & Cities & Observations & Cities \\
\hline 1,642 & 262 & 1,952 & 328 & 1,688 & 269 \\
\hline \multicolumn{6}{|c|}{$\begin{array}{l}\text { "Not statistically significant from zero. } \\
\text { Source: Author's calculations from Ontario Financial Information Return. }\end{array}$} \\
\hline
\end{tabular}

than keeping all services in-house. Or there may be cost-savings benefits to partial contracting if it spurs municipal staff to cut costs.

I test the effect of gradually increasing the share of contracted services from 0 to 100 percent in each of waste collection, recycling, and disposal (figure 6.4). Predicted costs per person for disposal and recycling services are highest when municipalities contract out between 20 and 60 percent of services, rather than when they do not contract out any services. In these cases, costs per person are between $\$ 10$ and $\$ 20$ higher than cities that do not contract out services. In both waste collection and recycling, costs are lowest when cities contract 100 percent of their services.

\section{How Contracting Improved Waste Service in Toronto}

Contracting has additional benefits than cost-savings. A well-designed contract with clearly defined outcomes also ensures consistent service quality (see above). 


\section{Figure 6.4: Costs per Person of Waste Services and the Extent of Contracting}

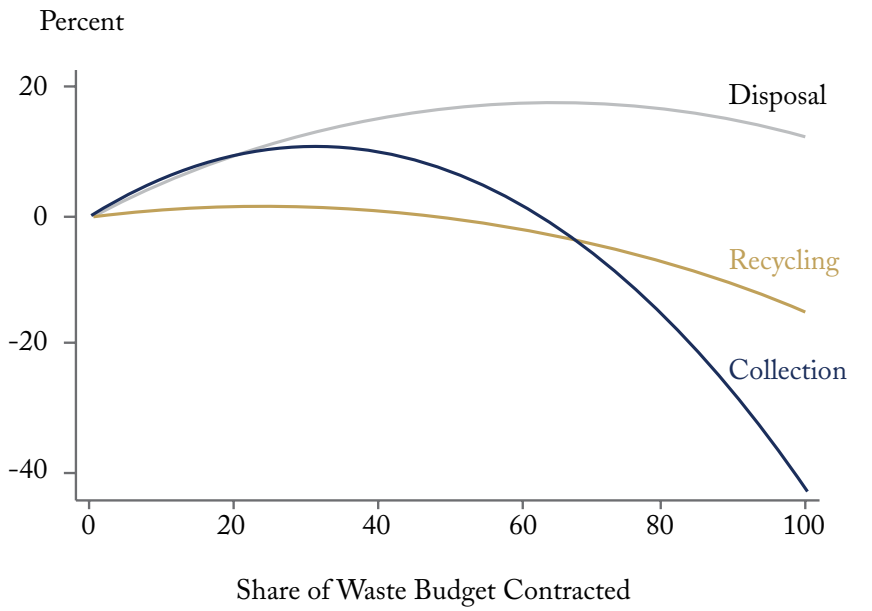

Source: Author's calculations from Ontario Financial Information Return.

Toronto has seen considerable cost savings by increasing its reliance on contracted waste services (see chapter 1 ). The results from figure 6.4 reveal that Toronto could save more money by contracting out all, rather than only some, of its waste collection services. The city has provided the data to show - and created the circumstances to test - how contracting can improve services: it breaks out daytime household waste collection to four districts of roughly equal size across the city. Since August 2012, Green for Life, a private company, has been collecting waste in Toronto in the area between Yonge Street and the Humber River (District 2). Toronto's contract with Green for Life sets out performance targets relating, for instance, to diversion rate, customer complaints, and number of health and safety violations. The contractor is held accountable for failing to meet any performance target.

With Jacob Kim, I conducted an analysis based on 312,844 records from 311 service request calls from January 2010 to June 2015. 
Our analysis shows a significant reduction in the number of calls per household concerning missed pickups in the districts with contracted waste services. Over the same period, complaints rose in the publicly serviced districts east of Yonge Street (Dachis and Kim 2018b).

Figure 6.5 shows the quarterly number of complaints per 1,000 people. The vertical line marks the beginning date of contracted services in District 2. We classify districts into three groups: publicly serviced (Districts 3 and 4), the areas that were contracted out in 2012 (District 2), and Etobicoke, which contracted out residential collection in 1995, before Toronto was amalgamated (District 1).

The average monthly complaint rate in District 2 has been reduced by 28 percent since services were contracted out. That reduction includes a large short-term spike in the complaint rate shortly after the change to contracted services (presumably while contractors learned the ropes). The same cannot be said about Districts 3 and 4 , where the average complaint rate rose by 9 percent. The complaint rate is essentially unchanged for District 1 (Green for Life eventually bought the contractor providing waste collection in District 1). As a result, in addition to cost savings (\$11.1 million per year), residents of Districts 1 and 2 are enjoying improved service quality. Cities, then, can enjoy both lower costs and better service with contracting.

\section{Conclusion}

Canadians have become dependent on many of the services that cities provide. Between protective services, waste collection, public transit, and water services, our daily lives depend on these critical municipal functions. But costs, particularly for wage-related costs, are rising. For cities to get the most out of their existing municipal services, they should look to the most cost-effective ways of operating them. Private contractors may be the answer, but it is more likely to be existing staff. The best way to know is through open contracting. 


\section{Figure 6.5: Number of Waste Collection Complaints per Thousand People}

Number of Calls

per 1000

Households

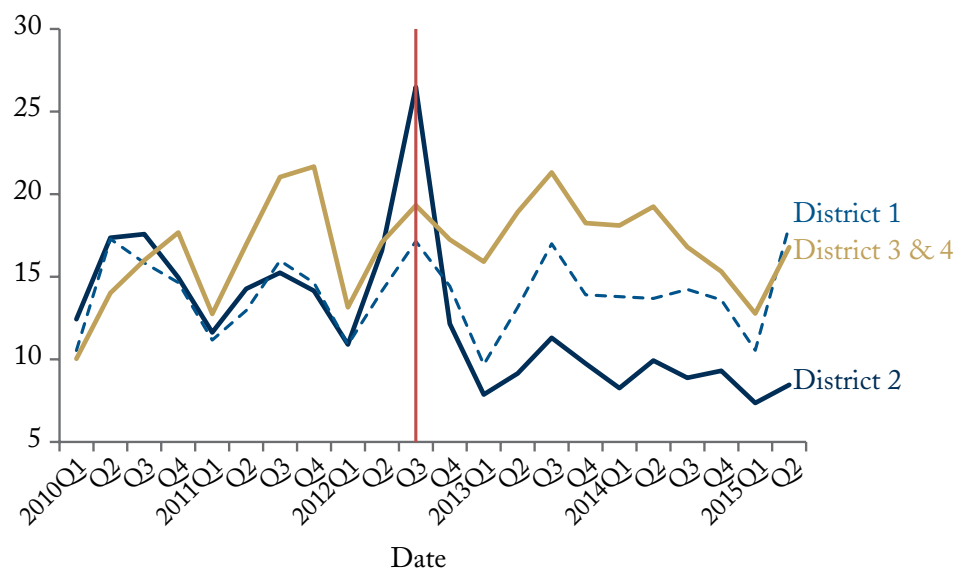

Source: Dachis and Kim 2018b.

Contracting waste and transit services - not banning strikes - is the best way to avoid stinky garbage strikes. 


\begin{tabular}{|c|c|c|c|c|c|c|c|}
\hline & (1) & (2) & (3) & (4) & (5) & (6) & (7) \\
\hline & Log Cost & $\begin{array}{l}\text { Log Cost } \\
\text { Collection }\end{array}$ & $\begin{array}{c}\text { Log Cost } \\
\text { Disposal }\end{array}$ & $\begin{array}{l}\text { Log Cost } \\
\text { Recycling }\end{array}$ & $\begin{array}{l}\text { Log Cost } \\
\text { Collection }\end{array}$ & $\begin{array}{c}\text { Log Cost } \\
\text { Disposal }\end{array}$ & $\begin{array}{l}\text { Log Cost } \\
\text { Recycling }\end{array}$ \\
\hline $\begin{array}{l}\text { Contract- } \\
\text { ed share }\end{array}$ & $\begin{array}{c}-0.324^{* * *} \\
(-4.83)\end{array}$ & $\begin{array}{c}-0.487^{* * *} \\
(-3.03)\end{array}$ & $\begin{array}{l}0.177 \\
(1.33)\end{array}$ & $\begin{array}{c}-0.163^{*} \\
(-1.70)\end{array}$ & $\begin{array}{l}0.715^{*} \\
(1.80)\end{array}$ & $\begin{array}{l}0.557^{*} \\
(1.80)\end{array}$ & $\begin{array}{l}0.130 \\
(0.44)\end{array}$ \\
\hline $\begin{array}{l}\text { Contract- } \\
\text { ed share } \\
\text { squared }\end{array}$ & & & & & $\begin{array}{c}-1.136^{* * *} \\
(-3.71)\end{array}$ & $\begin{array}{l}-0.435 \\
(-1.30)\end{array}$ & $\begin{array}{l}-0.277 \\
(-1.02)\end{array}$ \\
\hline Controls & $\begin{array}{l}\text { Year, } \\
\text { Service } \\
\text { type }\end{array}$ & Year & Year & Year & Year & Year & Year \\
\hline Constant & $\begin{array}{c}3.504^{* * *} \\
(61.60)\end{array}$ & $\begin{array}{l}3.627^{* * * *} \\
(31.44)\end{array}$ & $\begin{array}{c}3.660^{* * * *} \\
(63.24)\end{array}$ & $\begin{array}{l}3.305^{* * *} \\
(48.59)\end{array}$ & $\begin{array}{c}3.484^{* * *} \\
(28.01)\end{array}$ & $\begin{array}{c}3.622^{* * * *} \\
(58.00)\end{array}$ & $\begin{array}{c}3.266^{* * * *} \\
(44.74)\end{array}$ \\
\hline $\begin{array}{l}\text { Observa- } \\
\text { tions }\end{array}$ & 5282 & 1642 & 1952 & 1688 & 1642 & 1952 & 1688 \\
\hline $\begin{array}{l}\mathrm{t} \text { statistics } \\
{ }^{*} \mathrm{p}<0.10\end{array}$ & $\begin{array}{l}\text { parenthes } \\
p<0.05, *\end{array}$ & $p<0.01$ & & & & & \\
\hline
\end{tabular}

\section{Appendix}

I use regression estimates of average total costs per person (table 6.A1) in each of disposal, recycling, and collection. I use a fixed effects regression model, which will control for observed and unobserved municipality-specific factors. For example, some cities' landfills might be far from urban areas or have different spatial structures. For effects that vary from one year to another but are the same for all municipalities, such as fuel costs or weather, I include year-effects to control for cost changes that might have occurred in a given year. I also use quadratic estimates of contracting out to establish the relationship between contracting out and average costs per person. For more details on the regression I use, see the discussion of the identical model used in Dachis (2010). 


\section{Chapter 7}

\section{The Cost of Traffic Congestion - and Its Cure}

If removing the trash is the municipal service you miss most when it is not available, the roads in your city are probably the service you spend most time with - but not willingly. That lost time sitting in traffic has an economic and social cost as well.

Canadian governments are making huge investments to deal with traffic congestion. The federal government has plans to increase spending by tens of billions of dollars on items such as public transit, affordable housing, recreational facilities, flood protection, and other green and social infrastructure. To take a few provincial examples, Ontario plans to spend $\$ 106$ billion for transit and transportation projects over the 2017-26 period (Ontario 2018). Alberta plans to spend nearly $\$ 7$ billion on road and bridge infrastructure over the 2015-20 period (Alberta 2015). These funds, both direct spending by provinces and grants to cities, are intended to overcome the "infrastructure deficit" that municipal governments complain they have.

Government spending on major infrastructure is necessary to ensure that people can move around in growing cities. But putting more money into infrastructure doesn't solve the congestion 
problem; it merely postpones the next crisis. The best way to reduce congestion, and at much less cost, is to use prices to allocate scare road space. Canada has a pricing deficit, not an infrastructure deficit. A price on roads will encourage better use - and open more ways to finance critical urban infrastructure.

Governments around the world have put in place policies that have dramatically cut the cost of congestion. In cities as different as London and Houston, Stockholm and Miami, Singapore and Minneapolis, governments have implemented the right kind of system to fit their need (see below). The one common factor among them is a price for using roads. That fee not only reduces congestion but distributes the cost of building and maintaining roads among users, rather than imposing the large bill on all taxpayers.

\section{The Economic Cost of Congestion}

The standard approach to identifying an economic problem is to compare the market outcome to the socially optimal outcome. The market outcome is that in which travellers take into account only their own demands and private costs. It differs from the optimal outcome when there are "externalities" - private actions that impose costs or confer benefits on society at large which private decision-makers do not take into account in their decisions. Regional transportation involves two such externalities: congestion and agglomeration. Congestion is the visible cost you feel every time you are stuck in traffic; forgone agglomeration economies are the hidden cost of congestion.

\section{The Visible Cost of Congestion}

Traffic congestion slows down traffic. When a driver enters a roadway, she bases her travel decision on the private cost (such as her time, parking, and vehicle operating costs) of driving a car. She does not take into account that her choice may prevent others from using that road or slow them down when they do. Other drivers on the road impose the same cost on her. This is the irony - and economic 
problem - of traffic congestion. People say they are "stuck in traffic," as though everyone else is the problem. When everyone is thinking only about the cost to themselves of getting on the road, the result is traffic congestion. And that becomes a much wider social and economic cost.

A toll on a driver can equate the private cost to the driver with the broader social cost. The government should set the toll to be equal to the cost on other users of that driver entering the freeway.

Most existing studies of the economic cost of congestion start with an estimate of how long it takes a traveller to make a trip, such as one to work. The studies then compare that current travel time to a similar trip without congestion. Finally, they multiply the difference by a dollar amount that reflects the assumed value people place on their time.

To estimate these visible costs of congestion, Transport Canada (2006a, 2006b) calculated the economic cost in major Canadian cities from longer travel times and the additional cost of less reliable travel times requiring people to include contingency time in their travel. It calculated the total economic cost of congestion by multiplying the amount of time that commuters and other drivers lost due to congestion by the assumed value those travellers placed on their time. These costs amount, in 2002 dollars, to $\$ 2.5$ billion per year in the Greater Toronto and Hamilton Area (GTHA), or $\$ 473$ per person, and $\$ 5.2$ billion overall in Canada's five largest cities (Lindsey 2009, cited in Dachis 2011). Other costs include additional greenhouse gas emissions and fuel consumption due to waiting in traffic.

These visible congestion costs are highest in Toronto and Vancouver. An estimate for the GTHA was produced by Metrolinx (2008a), the regional transit body, at \$6 billion per year in 2006 dollars. HDR, Inc., an engineering consultancy, has studied the 
economic costs of congestion for Metro Vancouver (HDR 2015). Those total costs amount to $\$ 487$ million per year, growing to slightly over $\$ 1$ billion by 2045 , given population growth.

\section{The Hidden Cost of Congestion}

In addition to these visible costs, there are the hidden and wider economic costs of trips forgone altogether. It's easy to count the number of cars waiting in traffic, but difficult to estimate the number of trips that don't happen because drivers or transit riders know the journey will take too long to make it worthwhile. Because of congestion, workers don't take jobs that are the best fit for them; companies have a smaller pool of workers to draw from; people lose opportunities to learn from others around them; and businesses with unique offerings lack ready access to broader markets.

The idea of urban agglomeration combines two economic concepts: scale economies and externalities. Scale economies arise as a benefit that increases with the quantity of production or output. Urban scale economies arise when costs to a firm decrease or benefits increase as its surrounding market becomes larger because of the location decisions of others - a positive externality.

The benefits of urban living hinge on the relationships among people and firms. As more people live in a city or region, other people already in that area benefit. Jane Jacobs (1969) is perhaps the most famous writer to have shown the importance of firms in one industry benefiting from the proximity of firms in another industry. As well, agglomeration economies have been the subject of a large body of recent academic literature (see Rosenthal and Strange [2003] for further discussion). The benefits of co-location drive urban life. Natural advantages - such as the location of natural resources - explain only about 20 percent of the reasons why people locate in proximity to each other (Ellison and Glaeser 1999). 


\section{The Benefits of Urban Proximity}

There are a number of potential reasons for the externality benefits of urban proximity.

Labour Market Pooling: A larger labour market can benefit both firms and people, enabling a better match of a person's skills and interests to the specific needs of an employer. This benefit allows greater specialization of employees, resulting in increased economic efficiency, productivity, growth, and income. A second benefit is that a larger labour market can reduce risks for both employees and firms, allowing both to be less dependent on their existing relationships (Overman and Puga 2010; Duranton and Jayet 2011).

Learning in Cities: Knowledge dissemination is most effective in close proximity; as Marshall (1890) put it, having ideas "in the air" is akin to a public good. People learn better face to face. Learning more, and in less time, means higher incomes. As a potential example, a given patent is more likely to be cited by another patent from the same city (Rosenthal and Strange 2003). Workers also accumulate more valuable experience in larger cities, leading to higher incomes (de la Roca and Puga 2012). These benefits occur only when workers can reach common work areas, such as a downtown.

Sharing in Cities: In an urban area, firms and people can share inputs such as infrastructure, supplier networks, and other services (Holmes 1999). Cities also provide cultural and consumer amenities - arts and sports venues or restaurants, for example - that would otherwise not be cost-effective in areas with less accessible populations. Even customers already close to such amenities can be better off with less congestion or more transit because they alone may be sufficient to make the sporting venue or the new restaurant viable. Benefits can be region wide, and the potential beneficiaries of new transportation investments can be far away from the investment site.

\section{The Evidence of Agglomeration Benefits}

Taking all these positive externality effects together, what is the total effect of urban agglomeration on income? Empirical studies 
from around the world have found that doubling the size of an urban area tends to increase incomes there by between 3 and 8 percent (Rosenthal and Strange 2003). However, it is not immediately clear whether larger populations result in people earning higher incomes, or whether people with higher incomes tend to locate in areas with higher populations. In order to test which way the causality runs, a number of researchers (Ciccone and Hall 1996; Combes et al. 2010) have looked at historically large cities and found that larger populations result in higher incomes, and not vice-versa. The concept of workers clustering together in urban areas is so important that some economists think it is the cause of the tectonic shift in economic inequality across regions, particularly in the United States (Moretti 2012). Agglomeration forces are particularly strong in certain sectors, such as finance or technological industries (United Kingdom Department for Transport 2015). As Moretti argues, urban areas such as New York City or Silicon Valley have thrived in the last few decades while other places that were similar, but didn't have the right mix of people in industries with the strongest agglomeration potential, have stagnated.

The same economic force applies in Canada (figure 7.1). Across Canada, looking at Census Metropolitan Areas with a population greater than 25,000 in 2016 , doubling the size of a city increases the average income by 3 percent. The core takeaway is that the bigger an urban area effectively is, the richer people there will become. Congestion works against this powerful economic force and leaves Canadian cities at risk of falling behind the rest of the world.

\section{The Hidden Economic Cost of Congestion in Vancouver and Toronto}

Both Toronto and Vancouver have major transportation investments underway. In each city, the local transit authorities estimated how much their proposed investments would reduce congestion by increasing travel speed (Metrolinx 2008a and 2008b; HDR 2015). In addition, residents enjoy two types of hidden economic benefits 
derived from the greater travel opportunities resulting from these investments (see Dachis 2013 and 2015a).

The first and more important benefit of transportation investment is improved urban access. New transportation infrastructure and lower congestion allow current residents to access more of the region in the same amount of time as before. This broader access enables more connections than any person might otherwise have encountered, and that benefits others as well. Better transportation will increase travel speeds, making it possible for commuters to travel a greater distance in the same amount of time. A larger travel area will mean more access and connections to other people, enhancing agglomeration economies. In both Toronto and Vancouver, this advantage represents about half the total economic benefit of reduced congestion. The second economic benefit relates to an increase in the ability of people to access more jobs - including higher paying jobs. This improvement in income will result in an increase in gross domestic product (GDP). Again, in Toronto and Vancouver, it represents the other half of the economic benefit of reduced congestion.

Bringing both totals together, the hidden economic costs of congestion that governments are tackling with their investments range from $\$ 1.8-\$ 6$ billion in Toronto, and from $\$ 0.6-\$ 1.7$ billion in Vancouver (as set out in table 7.1).

\section{The Effect of Increased Tax Revenue}

As workers move from lower-wage jobs to higher-wage jobs as a result of better transportation, government income-tax revenues increase. Using a marginal combined federal and provincial effective tax rate of around 30 percent, the increase in government revenue would be upward of $\$ 1.8$ billion in Toronto and $\$ 400$ million in Vancouver. That benefit provides some limited justification for federal or provincial support of local infrastructure projects. The largest beneficiaries of local transportation improvements, however, are local residents. 


\section{Figure 7.1: Income and Population with Income, by Census Metropolitan Area, 2016}

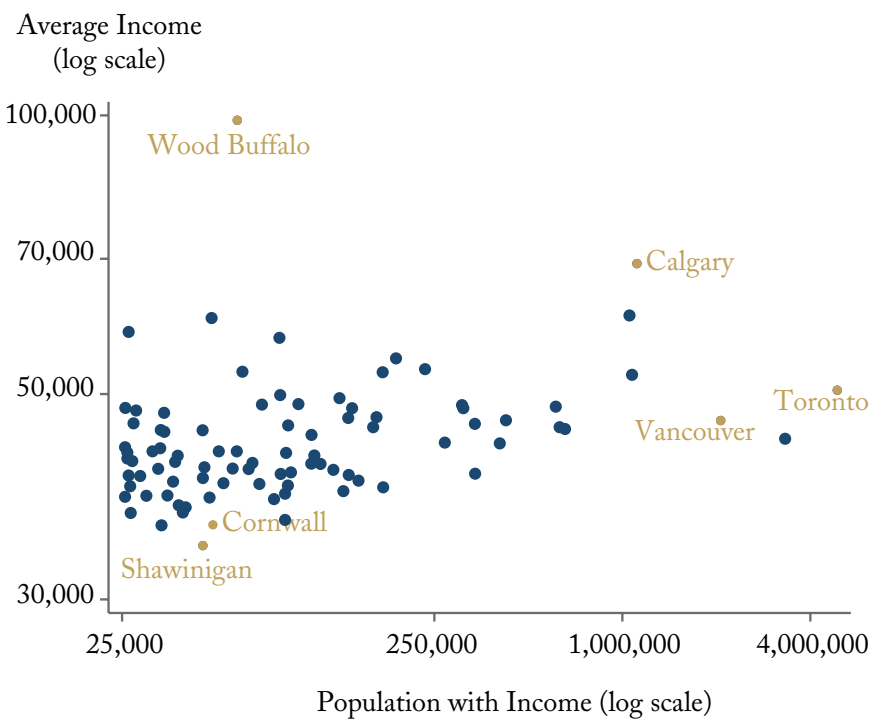

Note: Includes Census Metropolitan Areas and Census Agglomerations with 25,000 people or more.

Source: Author's calculations from 2016 Census, based on Dachis (2013,2015a).

Table 7.1: The Visible and Hidden Economic Cost of Congestion in Toronto and Vancouver

\begin{tabular}{|l|c|}
\hline \multicolumn{1}{|c|}{ Urban Area } & Hidden Cost of Congestion (\$billions) \\
\hline Toronto & $1.8-6.1$ \\
\hline Vancouver & $0.6-1.7$ \\
\hline
\end{tabular}


The net result of reduced congestion from transportation infrastructure is an increase in the values of properties of residents who benefit the most. Property taxes can capture some of this increase in value, especially if they are land-value capture taxes (see chapter 4).

\section{What Is the Right Level of Congestion?}

To assess the cost of congestion, policymakers need to assess the optimal amount of congestion they should strive for. Drivers would prefer roads with no traffic at all, ensuring no traffic congestion, but that would require an inefficient over-expansion of roadways. Increasing investment in roads to the point at which traffic flows freely, in the absence of any pricing, would result in a subsequent increase in demand to the point at which congestion would return to the previous level (Duranton and Turner 2011). This outcome is known as the fundamental law of road congestion. A free-flow baseline is, therefore, a reflection of road supply, not demand (Couture, Duranton, and Turner 2018).

Existing studies of Canadian costs of congestion use a measure similar to the free-flow estimate (Transport Canada 2006a). They compare actual traffic speed to an "acceptable" level that is 60 percent of the speed limit. They label a road as congested when the speed is below that measure (Wallis and Lupton 2013). An engineering definition of the optimal level of congestion takes the point at which the total flow through a road is maximized; congestion occurs when demand for the road exceeds this capacity. Maximizing the total throughput of a highway should be the goal of all governments.

Building new transit and roads will help provide more options for travellers across the region. However, new capacity can only do so much. As more options become available, more people start travelling. Before long the new infrastructure will be at capacity, and the same discussion about congestion will resume. The only long-term solution is to set a price on infrastructure that changes, based on 
demand. Tolls that vary based on the demand at any given time are the best way to achieve that goal (see below).

How do the positive agglomeration externality and the negative congestion externality interact around the tolling solution? The first step of introducing a congestion charge will result in a lower amount of travel, reducing the agglomeration benefit. However, using the funds raised to subsidize transportation infrastructure will result in an increase in demand. The optimal amount of travel at current net private costs occurs when the size of the positive agglomeration externality is the same as that of the negative congestion externality.

Governments should take the revenue from the congestion charge and put it back into transportation infrastructure. This framework also suggests that some cross-subsidization among areas in which agglomeration and congestion externalities interact will make the region better off. The actual amount of cross-subsidy will depend on the relative strength of the externalities in each region.

Earmarking money from congestion pricing to pay for transit infrastructure has more than an economic benefit. It can also help make the deal more palatable for drivers. If a regional transit agency operates well, building the right kinds of projects in the right places, drivers across the region know they have other transportation options available so long as they are willing to pay more for accessing them (see chapter 5).

\section{Road Pricing: The Cure for Congestion and Fairness for Taxpayers}

The best solution for traffic congestion is a road toll. A toll that goes up as traffic increases would give drivers ready access to a free-flowing highway. A toll for using a road not only reduces congestion but improves the fairness of government spending. Opponents of road pricing call it "double taxation" of drivers because both the tolls and 


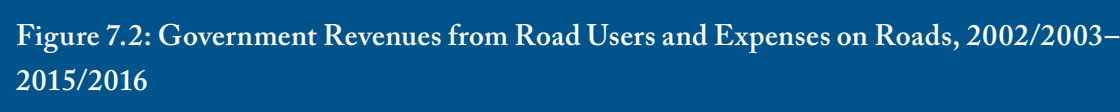

\section{\$ Billions}

(2016 dollars)

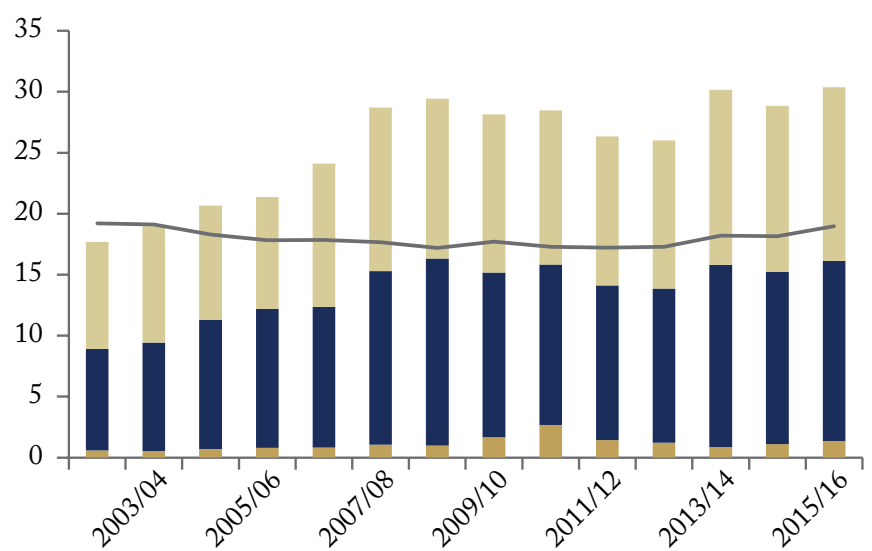

Local Expenditures Net of Federal and Provincial Transfers*

- Provincial/Territorial Expenditures Net of Federal Transfers

- Federal Operating Expenditures, Tax Expenditures, Capital Expenditures and Transfers

- Federal and Provincial/Territorial Revenues from Vehicle Fuel Tax, Licences and Fees

*Local road expenses are missing from Transport Canada data from 2009/10 onward. I estimate local expenses by assuming they hold at the same historical ratio to provincial expenses from 2002/03 to 2008/09. Local revenues from road users are negligible.

Source: Author's calculations from Transport Canada Statistical Addendums, as described in Dachis (2011).

part of government tax revenues go toward building and maintaining roads. Road pricing could bring the price that drivers pay for infrastructure they use closer to its actual cost. Gas taxes (which are about 85 percent of road-related revenues), vehicle licences, and other revenues from drivers have covered less than 70 percent of roadway expenses across Canada since 2008 (figure 7.2). Fuel taxes will be an 
unsustainable revenue source: as vehicles become more fuel-efficient, they use less fuel - and revenues have been falling in real terms since 2002/03. If electric vehicles take off - something some provinces are heavily subsidizing - fuel-tax revenues will plummet further in the coming decades.

\section{Comprehensive Road Pricing}

Canada is far behind the rest of the world in having a price on roads. There are a number of prominent models of road pricing around the world, according to Robin Lindsey (2007). Foremost for many will be London's congestion charge. Set up in 2003, the charge as of October 2017 is $11.50 \mathrm{GBP}$ (pounds sterling) and is levied on any vehicle that enters the city centre between 7:00 am and 6:00 pm, Monday to Friday. Some vehicles and residents within the zone receive a 90 percent discount.

The charge has been successful at reducing congestion. In fact, a short-lived expansion of the congestion charge area in 2007 resulted in a worsening of congestion, proving that a congestion price works. The expansion applied to a largely residential area, meaning that a large number of drivers became eligible for the discount. When the charge zone shrunk back to its original size, congestion fell back.

Other cities around the world, such as Singapore and Stockholm, have successfully put in place similar congestion charges. Canada has only a few examples of road tolls - the most prominent being Highway 407 in suburban Toronto.

These international examples show that there are many design models for road pricing. The key to getting road pricing right is to pick a system and a design that is going to work for the local community. Economists aspire to having every kilometre of every road subject to a toll, but the politicians will want to put in place a road pricing scheme that will be accepted and not impede their 
re-election. Time and time again two core themes emerge to stymie plans to introduce road pricing:

- drivers want alternatives if they are going to be asked to pay a toll; and

- drivers will not accept paying for something when they have received it free in the past.

These objections might well evaporate, especially once drivers see first hand that congestion pricing is an effective way to get traffic moving. However, there is a way to introduce a form of road pricing across many Canadian cities that will greatly reduce the economic cost of traffic congestion while, at the same time, offering drivers both a free alternative to road tolls and not necessarily making them pay to access roads they've had access to before. The solution is high-occupancy toll lanes, or HOT - a popular topic in transportation circles.

\section{A Smarter Solution: HOT Lanes}

HOT lanes are usually a single highway lane that car pools can access for free but are also available to single-occupant vehicle drivers who pay a toll. Modern HOT lanes, separated from general-purpose lanes by special pavement striping or simple vertical barriers, are easy to install. The price to access a HOT lane would vary based on demand. Prices would be low at night and high during rush hour, to ensure that the lane is congestion-free. They could be posted on road signs before the entrance, so drivers could decide if the potential time savings were worth the toll.

There would be no need for toll booths. Solo drivers would pay electronically, through either a transponder or licence-plate-recognizing photos. The simplest way would be for carpools to access the lanes for free with an opt-in transponder system, and the driver would simply turn on the transponder when using the HOT lane in carpool mode. The pre-registration system would reduce the number 
of vehicles the highway operator needs to check visually and to fine offenders. Pre-registration would return carpool lanes to their original purpose of encouraging ride-sharing during peak periods. Casual or family carpools that would have driven together anyway would no longer have free access to carpool lanes - unless they registered.

When drivers are not in a carpool, they would need to turn off the carpool mode on their transponder - as drivers on the Minneapolis HOT lane do. Georgia's HOT-lane drivers have an app that lets them switch on and off whether they are driving a carpool vehicle. Traffic police need only look at vehicles with transponders set to carpool mode. Everyone else pays, making enforcement of the carpooling rules easy.

All other vehicles would be able to use the lane, with the highway operator using photo-recognition of licence plates to determine where to send the bill. HOT lanes are common across the United States, in San Diego, Seattle, Miami, and many more cities in between. They have worked well. Minneapolis converted its HOV (high-occupancy vehicle) lanes into HOT lanes. A study there found that the economic benefits of doing so were more than double the operating and capital costs (Cao et al. 2012). Provincial and municipal governments in Canada's largest cities could easily transform existing and proposed carpool and bus lanes into HOT lanes.

Many drivers have seen first hand the problems with traditional carpool lanes. They are often underused during rush hour. That leaves more single-occupant vehicles in general-purpose lanes. The result is that traditional carpool lanes reduce overall highway capacity and worsen congestion. Traditional carpool lanes benefit a handful of drivers who are in carpools. As a rule, many carpoolers would have driven together anyway, whether work colleagues, friends, or families. Carpool lanes don't change travel behaviour much, so they are ineffective at reducing congestion. If currently congested or slow-moving carpool lanes were converted to HOT 
lanes, they could have their minimum carpool thresholds increased to three or more individuals per vehicle to ensure free-flowing travel.

Carpool lanes help the few who happen to be driving with their families but slow down the rest of the drivers. HOT lanes make everyone better off. Drivers move between HOT and free lanes based on how they value the time spent on a particular trip. That switching maximizes each driver's use of highway space. Jonathan Hall (2018) has found that adding a HOT lane shortens rush hour, which directly helps all road users. He finds that the economic benefits of reduced congestion from HOT lanes are more than $\$ 1,000$ per road user per year.

Tolling only one lane allows choice for drivers. They can either use the regular non-priced lanes or try the HOT lane. That gives drivers an affordable option that policymakers always claim to be looking for. There's an economic benefit to having a choice too. When people choose to use either the toll lane or the free lane, they choose the option that best suits their needs. People in the most urgent time crunch can get to where they need to go quickly: as an example, plumbers or electricians can do one more job in a day. Those in less of a rush can stay in the congested, but free, lanes.

With a HOT lane, the economic benefit per lane of putting tolls on only one lane is higher than the per-lane benefit of tolling every lane. Tolling the whole highway gets the most benefit, but there's also more economic harm. According to Hall (2018), tolling only one lane out of three available lanes gets half the economic benefit, without the economic harm to people who cannot afford the toll (see figure 7.3). Tolling more than one lane increases the economic benefit, but more people feel the economic harm.

The best part of a properly priced lane is that it can have higher overall capacity than a toll-free general-purpose lane. The reason? Hyper-congestion: a full lane on a highway can see dramatic 
reductions in capacity if a few more people try to get on the road (see Hall [2018] for a thorough discussion on the concept). Imagine a doorway that two people can barely fit through at one time. If a third person tries to join them, none of them will get through. That's hyper-congestion. A demand-varying toll for the highway, like the door, can be set to make sure there are not more people trying to access the highway than it can handle. Increasing the capacity on the now-tolled lane means people who would have been in the free general-purpose lane are now in the tolled lane. That means less congestion in the free general-purpose lane (which will be short lived, because more drivers will enter, but capacity will increase). Hence, turning an existing hyper-congested general-purpose lane into a toll lane can increase the overall capacity of the highway, which means more people able to use the highway, both people using the toll lane and others using the non-tolled lanes.

As Lindsey (2007) argues, claims that road pricing hurts the poor are exaggerated. HOT lanes do not necessarily favour only those who can afford to pay the toll: these lanes are also available for public transit, which moves faster as a result. As well, the majority of HOT-lane users, both high and low income, use HOT lanes only on occasion, mostly when their trips are urgent. In a review of surveys done of various U.S. HOT lanes, Jaffe (2013) finds that low-income drivers report they are just as willing to use HOT lanes as are survey respondents with higher incomes. Moreover, a free option will always be available, meaning HOT lanes do no harm to low-income drivers (figure 7.3).

\section{How to Get HOT Lanes Built Across Canada}

Let's make this example even more tangible by looking at where HOT lanes might make sense in Canadian cities. HOT lanes offer a more realistic alternative to the stillborn road tolling proposals that we've seen in Canada so far. Tolls were removed in British Columbia for a major Vancouver-area bridge in 2017 and for the Coquihalla 


\section{Figure 7. 3: The Economic Harm and Benefit of HOT Lanes}

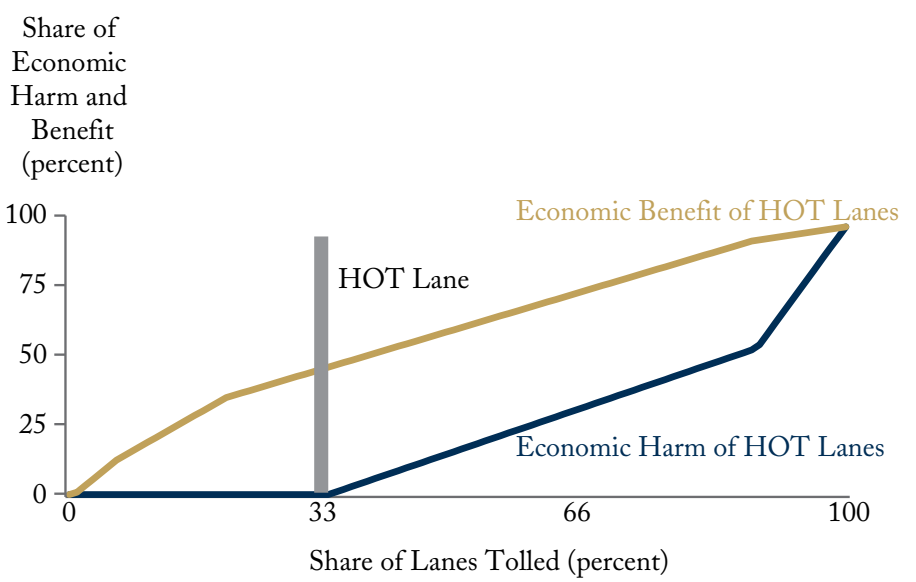

Source: Adapted from Hall (2018).

Highway in 2008. Plans for a toll on a rebuilt Champlain Bridge in Montreal were scrapped after the 2015 federal election (the federal government, in a quirk of history, is responsible for that bridge). Over the next few decades Ontario plans to build hundreds of kilometres of carpool lanes on many 400-series highways in the Greater Toronto and Hamilton Area (GTHA). The province has permanent carpool lanes on highways in Mississauga, Halton Region, and north Toronto. Meanwhile, British Columbia is expanding the number of carpool lanes on the Trans-Canada Highway in the Vancouver area, while freeways in Calgary and Montreal offer good potential as the future homes of HOT lanes.

\section{Toronto}

About a decade ago, among other new tax powers, Ontario granted the City of Toronto - and only Toronto - the power to levy tolls on roads it operates. There was a catch, however: the province retained the final say by having to pass a regulation allowing such a road 
toll. In December 2016, Toronto City Council voted in favour of asking the province to allow Toronto to place tolls on the Gardiner Expressway and the Don Valley Parkway. The following month, Premier Kathleen Wynne announced that she would not allow the city to proceed with road tolls. Instead, the province would raise the grant to cities from the provincial fuel tax. This solution presents many problems: the fuel tax is fast becoming a dwindling source of revenue, and grants create other issues (see chapter 3).

The Toronto City Council had planned a flat toll fee of about \$2, but flat fees are a mistake. A toll is most useful in reducing congestion if it varies, based on traffic demand. The toll should also reflect how far people drive. If the amount of the toll does not reflect demand, it is only a tax grab. No wonder the council's plan was rejected.

In rejecting the idea, Premier Wynne stated that she wanted commuters to have affordable options to tolls. HOT lanes offer that option. The province should work together with the City of Toronto to build a comprehensive network of HOT lanes. The province owns the 400-series highways, but Toronto owns the Gardiner Expressway and the Don Valley Parkway. The City of Toronto should convert similarly wasted GO bus lanes on the Don Valley Parkway to HOT lanes and put HOT lanes on the Gardiner Expressway and the rest of the Don Valley Parkway.

Ontario promised in its 2013 budget that it would open some HOT lanes on provincial highways, and in the years since it has regularly reiterated its commitment. However, progress has been very slow. By mid-2018, the province had installed only a single lane in each direction for a 17 kilometre stretch of the Queen Elizabeth Way between Oakville and Burlington. Rather than have the price depend on demand, drivers enter a lottery for the right to purchase a HOT permit for $\$ 60$ a month. This pilot program, introduced in September 2016, was intended to last for four years maximum. 
The program, as currently designed, is more likely to hurt the case for HOT lanes than help them. Because the price is fixed and paid upfront, the rate that HOT permit holders pay has nothing to do with ameliorating congestion. In fact, it may make congestion worse by, at certain times, having more cars in the HOT lane than it can handle. The pilot program risks associating HOT lanes with bad planning and worsening congestion. The province plans to introduce electronic tolling eventually, but only on a small stretch of a new expansion of Highway 427 in York Region. Even that small expansion isn't set to be open until 2021.

The province needs to think bigger when it comes to HOT lanes. Where should they be introduced in the Greater Toronto Area (GTA)? First, the existing network of traditional carpool lanes should all immediately turn into HOT lanes. The province installed 235 kilometres of temporary carpool lanes across the GTA during the Pan Am Games, stipulating that vehicles have three occupants to access them. These same lanes would form a natural region-wide HOT-lane network. Drivers from Burlington to downtown Toronto to Durham Region would have access to congestion-free travel.

Longer term, the province should look to expand this network by charging a time-varying toll on the 401 express lanes keeping the collector lanes free. That would put a toll on only half the lanes along the course of the 401, giving drivers the option of staying in the free collector lanes, if money is tight, or, if their time is tight, having access to a free-flowing lane.

\section{Vancouver}

In an early 2015 plebiscite, voters across the 21 municipalities in Metro Vancouver voted overwhelmingly to reject a transportation and transit plan financed with a region-wide 0.5 percentage point increase in the provincial sales tax. Although the economic costs of congestion there are high, voters didn't trust the regional transit authority, Translink, to deliver the right transit services for higher taxes. 
The story gets worse. In mid-2017 the provincial NDP ran on a campaign of eliminating the only places in the Metro Vancouver area that had tolls: the Port Mann and Golden Ears bridges. The tolls were removed on September 1, 2017, and, in less than a week, traffic was snarled: traffic volumes over the bridges increased by between 25 and 30 percent. Stories emerged of commuters from across the region seeing their commutes take twice as long. As more commuters flocked to the now toll-free bridges, other drivers stopped using already free bridges elsewhere in the region. The whole episode provided perfect proof of how tolls on roads can reduce congestion.

As a fixed charge, regardless of traffic flow, the tolls on the bridges were never meant to reduce congestion. The public was perhaps right to complain about the tolls. Their removal has a silver lining: it creates a clean slate that governments can work with to introduce more comprehensive tolling to reduce congestion across the region. But they need to act fast, before the memory of the increase in congestion from removing tolls fades and people in the region come to think of the highway as having always been free.

The timing works well, as the Mayors Council, the governing body over Translink, commissioned an independent report to recommend options for road pricing in the Metro Vancouver region (see chapter 5). The report, published in May 2018, showed many ways that a price on roads - referred to as mobility pricing or decongestion pricing - could reduce traffic (Mobility Pricing Independent Commission 2018). As the government considers what to adopt from the report, it should look in particular at introducing HOT lanes on highways throughout the region. Indeed, B.C. road toll legislation (article 3 of the British Columbia Guidelines for Tolling) requires that a "reasonable un-tolled alternative" be available for any proposed road toll, and that tolls can be applied only on major projects that result in significant increases in highway capacity (Lindsey 2007). HOT lanes fit that framework perfectly. 
Metro Vancouver would get substantial revenues from a HOT system using existing or proposed carpool lanes. In 2011, I estimated that total revenue from converting existing Greater Vancouver Area (GVA) carpool lanes into HOT lanes along Highway 1 in the eastern part of the Metro Vancouver area would garner approximately $\$ 37$ million per year (Dachis 2011). Converting recently built HOV lanes on other Greater Vancouver Area highways would yield additional revenues the region could use to support transportation investment while simultaneously reducing congestion substantially.

\section{Montreal}

Montreal has HOV lanes on some of its highways that could easily become HOT lanes. Although many highways in Montreal are amenable to HOT lanes, an appealing road pricing option for Montreal is on the surrounding cordon, where tolls would be levied on bridge and tunnel traffic entering the city (Lindsey 2008). Lindsey estimates that Montreal tolls would raise between $\$ 180$ and $\$ 300$ million annually, and he finds even higher estimates of net revenues and economic benefits when road tolls are used to reduce existing distortionary taxes (such as fuel taxes, grants, and other tax revenues) levied to finance transportation infrastructure.

\section{Calgary}

Calgary could install a HOT lane on increasingly congested Deerfoot Trail. In 2011, I estimated that total annual estimated HOT revenues from the city's section of the Deerfoot Trail could be approximately $\$ 40$ million per year (Dachis 2011). Tolls could also be applied on the ring roads around the city. Although having entered into service only a few years ago, these roads are already seeing traffic congestion, demonstrating the fundamental law of road congestion.

\section{Let's Keep Canada's Cities Moving}

Congestion is inflicting enormous economic costs on Canadian cities. It means commuters can't be at work, at home, or enjoying a 
new play or restaurant in a timely way. However, congestion costs include more than traffic delay, crashes, and injuries. Traffic hurts people who are not even stuck in traffic. Offices are less productive, household chores are left to others, and restaurants and entertainment events have fewer customers. These hidden costs of congestion in major Canadian cities are at least as large as the visible economic costs. The economic cost of congestion in these cities is now in the billions of dollars per year.

Traffic congestion is not the inevitable fact of living in a thriving urban area. It's the result of a choice governments make not to properly price the services and infrastructure people demand. When too many people want more of what's available, the result is a shortage. There are two approaches to fixing a shortage: make more or charge a higher price. Making more when the price is too low means there isn't enough money to finance the new project. Without a price, the congestion problem on our roads will simply come back, but with more people stuck in traffic.

Traffic congestion is at its root a failure to use prices. It is no different from countries offering free bread, but only for those willing to wait in line for hours. Just as there's only so much bread to go around, especially if the bread is free and bakers or farmers are not paid much for it, there's only so much road space at a given time. Just as grocery stores easily solve the problem of meeting the world's demand for bread by setting a price, congestion is a basic economic problem in which governments need to put a price on roads to cut the cost of congestion. How they decide to step in is critical.

Each Canadian city is different. The best solution for Toronto might not be exactly the best for Vancouver, Montreal, or Calgary. The best approach to putting a price on roads isn't necessarily a comprehensive price on every single metre of roadway. Instead, it is one that policymakers will have the intestinal fortitude to put in place and stand behind come election time. Across North America, the 
most successful way to introduce road tolling has been by converting carpool lanes, which have proven to be unsuccessful at cutting congestion, into HOT lanes by charging a toll on some drivers to allow them access. It's time that cities and provinces across Canada install these lanes on their highways. 



\section{Chapter 8}

\section{Getting More Buildings for Our Bucks with Private Infrastructure}

Congestion on the roads, overcrowding on transit, and many of the ills of Canada's urban infrastructure are the result of bad pricing. The bad pricing is due to a deeper problem of government ownership and control of much of Canada's infrastructure. If Canadian cities relied on private infrastructure investors, the result would be better infrastructure at a lower cost to taxpayers.

Canadian governments have been far more timid than governments around the world in opening up the ownership of infrastructure. Earlier we discussed how private ownership is one step further than the contracting model in involving the private sector (chapter 6). Canadian governments have instead taken on most investments with taxpayer dollars: in 2016, more than half the $\$ 155$ billion under construction in major private and public Canadian infrastructure was financed directly by taxpayers. When Canadian governments do involve the private sector through public-private partnerships, it is often limited to using private debt-finance. Disguised by low government borrowing costs, Canadian cities' over-reliance on government 
ownership of infrastructure has led to inefficient management, poor project selection, and higher risks to taxpayers.

While Canadian cities struggle to fund and finance their own infrastructure investments, Canadian institutional investors, notably the seven largest Canadian public pension plans as well as global investors, are looking to participate in new user-fee-supported infrastructure - both in existing assets and in new projects. Canada's largest pension plans have invested $\$ 98$ billion of their $\$ 1$ trillion-plus in assets in infrastructure, but mostly abroad. Meanwhile, Canadian and foreign institutional investors, such as pension funds and insurance companies, would likely place a high value on Canadian userfee-financed infrastructure, but Canadian governments have opened few opportunities for such investment.

Canadian cities own a large share of the existing infrastructure in Canada. However, users often don't pay the full price of much of it. We saw that on roads that are plagued by congestion (chapter 7). Until the prices that users pay match the cost, taxpayers will need to subsidize water and roads. However, many Canadian cities - especially those in Alberta and Ontario - own electricity distribution assets that are charging the full price to end users and are ripe for cities to divest. These provinces have strong regulators in place that can protect consumers, making it unnecessary for cities to own electricity distribution companies. These cities are sitting on assets worth between $\$ 15$ billion and $\$ 20$ billion which, instead, they could reinvest in critical infrastructure such as public transit.

To provide opportunities for investors to meet beneficiaries' needs through financing infrastructure, Canadian governments should create policies that support institutional investment in both existing assets and new infrastructure. Existing government-owned, user-fee-financed assets offer the greatest potential for government revenue from asset sales, including partial sales in which governments retain economic control. Governments could use the proceeds 
from such institutional investment to fund new infrastructure along with institutional investors. Taxpayers would benefit from better use of existing assets, as would users of more efficient infrastructure.

\section{Why Use Private Capital When Public Money Looks Cheaper?}

There are three kinds of financing models for infrastructure in Canada:

- private finance, in which private companies finance and own the infrastructure;

- public-private partnerships (also known as $\mathrm{P} 3 \mathrm{~s}$ or PPPs), in which governments contract with private builders and financers, but own the infrastructure; and

- direct funding from governments or Crown corporations.

Fully private equity finance for Canadian public access is incredibly rare. Almost all major private investments in infrastructure, such as a pipelines and fossil-fuel infrastructure, are for the sole benefit and use of a private company.

Canadian governments turn to P3s mostly at the early stages of design, building, and financing to protect taxpayers from bearing the risk of construction overruns and delays. After completion, governments have typically taken back infrastructure ownership and longterm operating risk. Ontario and British Columbia have led the way in using P3s, initially to build public buildings such as hospitals and justice facilities, but recently to include transportation and other civil infrastructure projects.

Instead, most Canadian infrastructure is funded and financed with taxpayer dollars. Such taxpayer-funded investment has a broader cost to society through the risk of cost overruns, the burden that taxation places on the broader economy, and the politicization of infrastructure investment decisions that can lead to poor choices and lower-productivity infrastructure. 


\section{The Risk to Taxpayers}

One of the most common arguments favouring government infrastructure investment is that it typically benefits from a lower borrowing rate compared to that available to the private sector (Auditor General of Ontario 2014). However, this lower interest rate is a result of bondholders viewing taxpayers as the guarantors of any cost overruns or late delivery. The lower interest rate is an insurance benefit that taxpayers implicitly provide to bondholders (Boyer, Gravel, and Mokbel 2013). Many people fall into this logical trap. For example, the Auditor General of Ontario (2014) made this mistake when she said that Infrastructure Ontario's use of private-public partnerships had cost $\$ 8$ billion more than traditional public financing.

Why do investors like the security blanket of government bonds? Governments have the almost unfettered ability to raise money to cover cost overruns for nearly any project. Investors know that they'll get paid no matter how badly a government bungles its projects. Private companies can't do that. If their costs spiral out of control, they have far fewer options to be able to repay investors. Investors know that and, therefore, demand higher interest rates.

Public borrowing looks risk free for investors, but it isn't risk free for taxpayers. The government's borrowing rate is only one factor in evaluating individual investments. The risks that a particular infrastructure investment will have cost overruns or delays don't go away simply because the government is financing it. Rather, they can easily become a social cost. When we look at public versus private finance through this lens, what appears to be the lower cost of public borrowing is just an illusion.

If anything, because the government knows it won't go bankrupt if things do go awry, it has less incentive to keep a close eye on projects. In contrast, the $\mathrm{P} 3$ model has largely been a success in limiting the risks of overruns. Of $30 \mathrm{P} 3 \mathrm{~s}$ in Ontario since 2007, 29 were 
completed below budget and 22 opened on time (Siemiatycki 2015). Infrastructure Ontario, one of the world's leading P3 operations, expressly values the risk savings from using $\mathrm{P} 3 \mathrm{~s}$ when evaluating its major projects. As Robins (2017b) finds, of the $51 \mathrm{P} 3$ projects completed by Infrastructure Ontario by 2016, 96 percent were completed on time and 73 percent were completed on budget. Looking at a previous audit, although $\mathrm{P} 3$ projects had financing costs $\$ 8$ billion higher than they would have been with traditional public-sector delivery, the lower risk led to savings for taxpayers. The $\$ 8$ billion in higher financing costs saved Ontario taxpayers $\$ 6.6$ billion (figure 8.1).

\section{The Economic Cost of Taxation}

Raising taxes imposes a cost on the overall economy, lowering the social rate of return. Economists call it the marginal cost of public funds. When a government raises an additional dollar of revenue through taxes to finance an infrastructure project - whether through income tax, fuel taxes, a consumption tax, or any other tax not directly related to the use of infrastructure - it affects the decision-making of a firm or a person. This cost is an economic harm, because, for example, a firm may put off hiring decisions or a consumer may delay spending decisions. One measure of this harm is known as the marginal cost of funds (Dahlby 2009).

The specific kind of economic damage caused by raising revenues depends on the tax (see chapter 3). The marginal cost of funds measures the change in economic behaviour due to the government raising additional revenue and varies by the type of tax, with corporate income taxes having the highest cost and consumption taxes having the lowest cost (Dahlby 2009). This negative effect means that governments must calculate the marginal cost of funds for every dollar of revenue they raise to finance a project. Once all the potential projects have been assessed based on these externalities, governments can select the projects they will subsidize or finance entirely. However, as the government funding envelope for infrastructure 


\section{Figure 8.1: Expected Costs of Ontario P3 Delivery vs Public-Sector Delivery (\$Billions)}

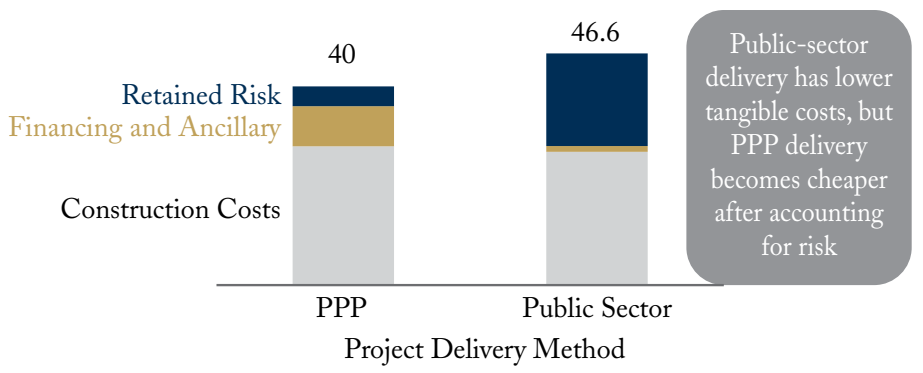

Source: Robins (2017b).

investment expands and more tax revenue is needed to finance infrastructure investment, the economic damage increases.

In contrast, when users pay the full cost of infrastructure and there are no positive externalities of their using infrastructure, they equate private rates of return with social rates of return: that is, user fees have no externality cost on the rest of the economy. For all public investments, taxes cover the difference between user charges and costs. Thus, if a private investor were to finance a project directly and recoup the investment with user fees, there is no distortion through higher taxes to either the work or the investment.

\section{The Productivity and Project Selection Discipline of Institutional Investors}

Involving private or institutional investors can bring greater discipline to the selection of government infrastructure projects as well as to better long-term operation, leading to more efficiently run services. In public transit, for example, numerous debates have been held about the merits of some proposed new government-selected rail lines and transit stations. When policymakers alone decide such 
investment decisions, the public is left to determine whether their promises are sound. The public often lacks the knowledge and expertise to assess information such as ridership figures, costs, and other project details (see below).

There is evidence that private operators can provide infrastructure services at a lower operating cost than a single public provider. Privately owned EU airports have lower aeronautical charges than publicly owned airports (Dachis 2014), while competition for providing water services - but not necessarily whether the service is public or private - results in reduced costs (Bel and Warner 2008). Lastly, waste services can also be provided more efficiently by private operators (see chapter 6).

Institutional investors, in contrast to governments, which depend on electoral results, can provide other benefits aside from cost reductions. Investor-owned infrastructure may be able to provide better-managed customer services, introduce technology that it is difficult for governments to fund, and have arm's-length relationships with customers and suppliers. Perhaps most important, institutional investors with the ability to put a user fee on currently non-priced and congested infrastructure such as highways or transit can set prices to maximize the asset's efficiency (see chapter 7). The user-fee model also allows for penalties on infrastructure providers should the service not be reasonably available: for example, governments could levy fines for transit vehicles being out of service due to inadequate maintenance or failure to maintain cleanliness standards.

\section{Harnessing Private Capital for Infrastructure Investment}

In 2016, more than half the $\$ 155$ billion infrastructure projects under construction in Canada were financed directly by taxpayers. While Canadian governments worry about their limited ability to raise taxes and borrow to pay for this infrastructure investment, major Canadian institutional investors are investing in infrastructure 
abroad. If governments turned their focus on getting investors to put more money into Canadian infrastructure, the result would be better infrastructure, less cost to taxpayers, and more secure pensions.

\section{Canadian Infrastructure Investment Patterns}

The 100 largest infrastructure projects underway in Canada in 2016 ranged from hospitals to roads to airport expansions. They cost between $\$ 300$ million and $\$ 400$ million for small projects to more than $\$ 9$ billion each for major transit and hydroelectricity projects - and most have some kind of user fee. Direct funding from governments and Crown corporations is the largest source of infrastructure funding. Of the $\$ 155$ billion in 2016, Canadian governments and Crown corporations directly funded $\$ 83$ billion, or more than half (figure 8.2).

Although the largest amount of public funding was for energy projects - $\$ 44$ billion in 2016 - provincial and municipal governments also dedicated a large amount of direct funding to transportation projects. Combined, governments directly financed $\$ 30$ billion in 2016 .

\section{Canadian Institutional Investments in Infrastructure}

While Canadian governments mostly use government funds for infrastructure investment, Canadian pension funds and other long-term investors (institutional investors) are major infrastructure financers. They welcome infrastructure investments for many reasons.

Infrastructure investments provide a reasonable amount of certainty regarding long-term revenues. For pension funds, that certainty is useful in matching future distributions to participants.

- Many pension funds are in a position to invest now and are not worried about having to sell large investments, such as infrastructure assets, for many years.

- The value of infrastructure assets and their revenues, 


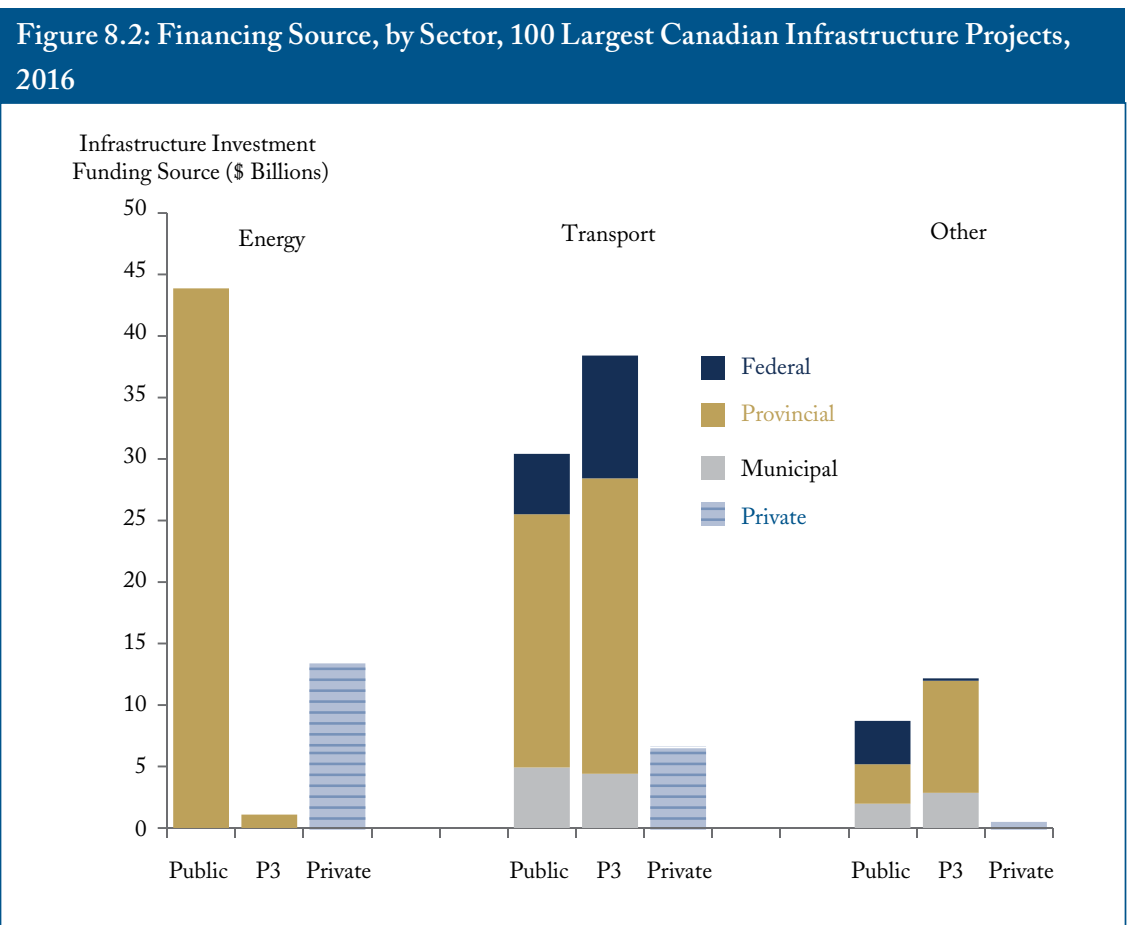

Note: Totals exclude uncommitted funding. All amounts in nominal dollars. Source: Dachis (2017b) interpretation of ReNew Canada (2016).

unlike traditional investments such as stocks and bonds, typically does not drop dramatically in economic downturns because demand for basic services such as water usually does not drop with the economy.

- The persistent low, and sometimes even negative, rate of return on traditional investments such as bonds means that institutional investors are seeking out new assets, including infrastructure, to generate sufficient returns to meet their liabilities.

At the end of their most recently available fiscal years as of publication of this book, Canada's seven largest pension funds held about $\$ 98$ billion invested in infrastructure assets, both in Canada 
and abroad (table 8.1). The Canada Pension Plan Investment Board (CPPIB) holds the largest portfolio of infrastructure investments, over $\$ 24$ billion. The Ontario Municipal Employees Retirement System (OMERS), the Ontario Teachers' Pension Plan (OTPP), the Caisse de dépôt et placement du Québec (Caisse), and the B.C. Investment Management Corporation hold the next largest infrastructure portfolios, each with between $\$ 11$ billion and $\$ 19$ billion in investments.

The largest transportation holdings are in toll roads, such as the CPPIB's investments in Australia, Chile, and Virginia; followed by airports, with the OTPP and Public Sector Pension Investment Board (PSPIB) holding large stakes in airports across Europe; and then railways, such as stakes by OTPP and OMERS in the British High Speed 1 Rail between London and the English Channel. Many Canadian pension funds work together to own international assets. For example, the CPPIB, OMERS, and OTPP each bought one-third of the company that will operate the Chicago Skyway toll road under a concession agreement until 2104.

Pension funds are not alone in investing in global infrastructure. Brookfield Infrastructure, a subsidiary of Canadianbased Brookfield Asset Management, is part of a consortium (which includes British Columbia Investment Management Corporation, the pension fund for B.C. government employees and other parties) that has invested $\$ 12$ billion in a major Australian seaport and rail operator. Brookfield also holds major investments in natural-gas pipeline infrastructure around the world, telecommunications infrastructure in France, and ports in Brazil.

For their part, Canadian insurance companies also seek out infrastructure investments because their long-term risks of paying out benefits matches the long-term infrastructure revenues. For example, Manulife has invested about 2 percent, or $\$ 6$ billion, of its $\$ 300$ billion investment fund in infrastructure (Manulife 2016). 


\section{Table 8.1: Canadian Pension Fund Infrastructure Investment}

\begin{tabular}{|c|c|c|}
\hline $\begin{array}{l}\text { Pension Fund and } \\
\text { Reporting Date } \\
\text { (ranked by } \\
\text { infrastructure }\end{array}$ & $\begin{array}{c}\text { Fair Value of } \\
\text { Infrastructure } \\
\text { Investments } \\
\text { (\$ billions })\end{array}$ & $\begin{array}{c}\text { Examples of } \\
\text { Canadian } \\
\text { Infrastructure } \\
\text { Investments }\end{array}$ \\
\hline
\end{tabular}

\begin{tabular}{|l|l|l|}
\hline $\begin{array}{l}\text { Canada Pension Plan } \\
\text { Investment Board } \\
\text { (March 2017) }\end{array}$ & 24.3 & Highway 407 \\
\hline $\begin{array}{l}\text { Ontario Municipal } \\
\text { Employees } \\
\text { Retirement System } \\
\text { (December 2017) }\end{array}$ & 18.1 & $\begin{array}{l}\text { Confederation Bridge, } \\
\text { Detroit River Tunnel, } \\
\text { Alectra }\end{array}$ \\
\hline $\begin{array}{l}\text { Ontario Teachers' } \\
\text { Pension Plan }\end{array}$ & 18.7 & $\begin{array}{l}\text { Container terminals } \\
\text { at Port of Vancouver }\end{array}$ \\
\hline
\end{tabular}

(December 2017)

\begin{tabular}{|l|}
\hline $\begin{array}{l}\text { Caisse de dépôt et } \\
\text { placement du Québec } \\
\text { (December 2016) }\end{array}$ \\
\hline
\end{tabular}

\begin{tabular}{|l|l|l|l|}
\hline (December 2016) & $\begin{array}{l}\text { Vancouver's Canada } \\
\text { Line }\end{array}$ & Australia, Europe, and U.S. \\
\hline $\begin{array}{l}\text { Public Sector Pension } \\
\text { Investment Board } \\
\text { (March 2017) }\end{array}$ & 9.5 & Telesat & $\begin{array}{l}\text { Airports and seaports in } \\
\text { Europe }\end{array}$ \\
\hline $\begin{array}{l}\text { B.C. Investment } \\
\text { Management } \\
\text { Corporation (March } \\
\text { 2017) }\end{array}$ & 11.0 & $\begin{array}{l}\text { Vancouver's Canada } \\
\text { Line; water utilities in } \\
\text { Canada }\end{array}$ & $\begin{array}{l}\text { Water, wastewater, and } \\
\text { energy in U.S. }\end{array}$ \\
\hline $\begin{array}{l}\text { Alberta Investment } \\
\text { Management } \\
\text { Corporation } \\
\text { (December 2016) }\end{array}$ & 5.3 & None & $\begin{array}{l}\text { U.K. train leasing; electricity } \\
\text { utility in Washington }\end{array}$ \\
\hline \begin{tabular}{l} 
Source: Updated from Dachis (2017b). \\
\hline
\end{tabular} & & & \\
\hline
\end{tabular}

\begin{tabular}{|l|l|l|l|}
\hline (December 2016) & $\begin{array}{l}\text { Vancouver's Canada } \\
\text { Line }\end{array}$ & Australia, Europe, and U.S. \\
\hline $\begin{array}{l}\text { Public Sector Pension } \\
\text { Investment Board } \\
\text { (March 2017) }\end{array}$ & 9.5 & Telesat & $\begin{array}{l}\text { Airports and seaports in } \\
\text { Europe }\end{array}$ \\
\hline $\begin{array}{l}\text { B.C. Investment } \\
\text { Management } \\
\text { Corporation (March } \\
\text { 2017) }\end{array}$ & 11.0 & $\begin{array}{l}\text { Vancouver's Canada } \\
\text { Line; water utilities in } \\
\text { Canada }\end{array}$ & $\begin{array}{l}\text { Water, wastewater, and } \\
\text { energy in U.S. }\end{array}$ \\
\hline $\begin{array}{l}\text { Alberta Investment } \\
\text { Management } \\
\text { Corporation } \\
\text { (December 2016) }\end{array}$ & 5.3 & None & $\begin{array}{l}\text { U.K. train leasing; electricity } \\
\text { utility in Washington }\end{array}$ \\
\hline \begin{tabular}{l} 
Source: Updated from Dachis (2017b). \\
\hline
\end{tabular} & & & \\
\hline
\end{tabular}

Toll roads in Sydney, Virginia, Chicago, and Chile; water utility in eastern England

Rail in U.K.; gas and electricity transmission in Texas and Europe; toll road in Chicago

\section{Rail in U.K.; toll road in} Chicago; water in Chile, Sydney, and U.K.; airports in Europe

\section{Trains in Europe; major} transport operator in (in development); Vancouver's Canada Australia, Europe, and U.S. Line

Airports and seaports in Europe

Water, wastewater, and energy in U.S. 
Although Canadian pension funds have a large number of investments abroad, few have major infrastructure investments in Canada, especially in categories usually owned by government. The rare examples include the CPPIB's minority stake in Ontario's Highway 407 ETR, a toll road in the Greater Toronto Area. OMERS also holds a long-term concession to operate the Confederation Bridge between Prince Edward Island and New Brunswick and has an ownership share in a rail tunnel between Detroit and Windsor as well as in Alectra, a local electricity distribution company majority owned by a number of Ontario cities. Lastly, the Caisse has an ownership stake in the company that built and still operates the light-rail commuter Canada Line in Vancouver and will be the majority owner and operator of a proposed Montreal light-rail system.

Institutional investors want to own domestic infrastructure because there are potential benefits that specifically come from domestic investments. Investments in Canada would allow pension funds and insurance funds to avoid the risk from inflation and exchange-rate differences between Canada and foreign countries. Canadian investors will also likely understand the political risks of investing in Canadian infrastructure, which is apparent in Canada just as much as in other nations.

$\mathrm{P} 3 \mathrm{~s}$ are a successful way of reducing risk in the design, finance, and construction stage of infrastructure (see above). Institutional investors, however, are not best placed to manage the construction risk in existing Canadian P3s and do not seek short-term investments. They have long-term investment outlooks that they want to match to their beneficiary obligations. Therefore, institutional investors are best placed to deal with the operational risks that occur over a lengthy period, given that they have a longer time in which to manage those risks. As a result, governments should open up long-term infrastructure positions, not just short-term construction projects. 


\section{Creating the Conditions for Institutional Investment in Canada}

Canadian institutional investors have not been able to invest in many domestic infrastructure opportunities because Canadian governments have not opened up ownership opportunities for them. Despite the expertise of Canadian institutional investors in infrastructure, why have Canadian governments not taken advantage of institutional or private investors to build more infrastructure? There are economic hurdles for institutional investment, but governments can overcome these problems with a few simple steps.

\section{The Potential for Market Failures with Private Investment in Infrastructure}

One concern with selling government-owned infrastructure to private or institutional investors is that the profit-oriented operator might act like a monopolist. If prices rose, the public would not view the switch in ownership as an economically efficient outcome.

There are, however, a number of potential positives from such market power. For example, a transit monopoly with a seamless network - in which users travel on buses, trains, or other transit within the same regional fare system - can create numerous benefits for travellers and operators alike. Indeed, those benefits may be so large that they make competing forms of public transit uneconomical.

Although a single transit network might be able to monopolize the specific service it provides, it could still have to constrain its market power by having to compete with other networks that offer similar services. Public transit is increasingly in competition with car-sharing services such as Uber. Airports and railways might look like monopolies in their own modes, but they compete with each other as well as with other modes of transportation that limit the market power of incumbent infrastructure owners. 
Some types of infrastructure might be a monopoly as a whole, but with some aspects that are competitive. In public transit or postal services, for example, only one organization is best placed to set a fare or rate policy for a region or a country. However, governments can still enter into contracts with private operators to provide specific services on a contracted basis (see chapter 6). In such situations, governments could limit the market power of service providers by allocating sub-contracts across a wide range of companies.

When competition or contracting for services is not sufficient to achieve economic efficiency, governments can instead regulate a private provider. The two most common models are rate-of-return and price-cap regulation. With rate-of-return regulation, regulators set prices so the overall shareholder return does not exceed a given rate. However, regulators usually have an information disadvantage relative to the infrastructure operator.

Another government option is to offer longer-term ownership concessions or franchises. Concessions or franchises differ from contracting. At the end of the lease term, the private concession or franchisee returns the asset to the government or sells it back to the government. One example is the Confederation Bridge, which will be privately operated until 2032, at which time the Government of Canada will own and operate it.

Retuning assets is not ideal for all types of assets. There is a risk that a franchise owner will reduce short-term costs by not properly maintaining the facility. However, a contract could require the necessary state of a facility, such as a simple bridge or a road, on turnover. With more complex infrastructure or infrastructure in which the future state of assets or liabilities is unclear, such as public transit, such requirements would be more difficult to enforce.

\section{Creating Regulatory Institutions}

The first step that governments, especially the provinces, should 
take before opening up infrastructure ownership is to create the appropriate regulatory environment. In many areas of public infrastructure, Canadian regulators either do not exist or do not have a mandate to provide price regulation for potential investor-operators. Policymakers at the provincial level should look to the numerous international examples of regulators in areas ranging from water to electricity to transit, instead of reinventing the regulatory model.

Creating an arm's-length regulatory agency for major infrastructure can have numerous benefits, independent of whether governments sell a stake in an asset. Without such an independent body, governments have an inherent conflict of interest when they hold the powers of both operating infrastructure and regulating its operational standards in areas such as safety or price setting. Weaker regulatory standards make the operations easier to manage. When the government has such a conflict, it can set regulations that hamper other competitors but benefit the Crown corporation. Creating an independent infrastructure regulator - for example, the United Kingdom created Ofwat for its water sector - can both address this conflict and monitor any potential private investors.

Under price-cap regulation, regulators set a maximum annual price increase for user fees, taking into account factors such as expected inflation and productivity gains. However, if regulators set maximum prices too low, that can lead either to congestion of the assets or insufficient rates of return for investors. In sum, regulation may be a necessary option for some kinds of assets such as water, storm water and wastewater, and electricity distribution that do not face obvious competition from other services. Internationally, independent regulators have been successful with both rate-of-return and price-cap regimes at reducing costs for infrastructure users and encouraging performance improvement - for example, with airports in the European Union and water regulation in the United Kingdom (Dachis 2014). 


\section{The Biggest Opportunity: Selling City-Owned Electricity Distribution Assets $^{28}$}

Canadian cities own assets in a number of areas. Three of the biggest by total asset value are water and wastewater infrastructure, roads, and electricity assets. Canadian cities are not setting the right prices for water and wastewater use (see chapter 11), and users aren't paying anywhere near the full cost of roads (see chapter 7). In neither roads nor water are the right regulators in place anywhere across Canada. The provinces need to act before cities can turn to selling roads or water-related infrastructure.

Electricity is a different story. Cities in the provinces of Ontario and Alberta, where municipalities have significant ownership stakes in local electricity distribution companies (LDCs), have the greatest opportunity. Both provinces already have regulators that set the rates for municipally and privately owned LDCs. These regulators have demonstrated an ability to protect consumer interests in those parts of the provinces where private utilities operate. The rates they set for utilities where municipalities sell their equity stake would not change, meaning that municipal ownership does not affect electricity prices or service. As a result, there is no compelling public policy rationale for continued municipal ownership, and the private sector has shown a strong willingness to invest in LDCs. Municipalities could sell their equity stakes and recycle the proceeds into priority infrastructure projects.

The more than 50 locally owned utilities in these two provinces represent 27 percent of Canadian electricity customers. In one of a series of C.D. Howe Institute essays looking at the value of government-owned infrastructure across Canada, Steve Robins (2017a) estimates that, collectively, municipally owned LDCs in Alberta and Ontario represent an asset worth $\$ 15-\$ 20$ billion for taxpayers in those cities.

28 This section draws heavily on the text from Robins (2017a). 
Private money in electricity distribution is hardly radical. Most jurisdictions around the world have some role for private distribution companies, which they manage by price-setting, rate-ofreturn regulation. In Canada, some residents of British Columbia, Alberta, Ontario, and Newfoundland receive their power from a privately owned LDC, while in PEI and Nova Scotia, 100 percent of electricity distribution is privately provided. Some Ontario municipal LDCs have 10 percent stakes held by private investors. In most of British Columbia and Quebec, provincially owned companies deliver electricity to customers.

In the United Kingdom, electricity distribution is provided through 14 privately owned distribution licensees, which were sold initially in the 1990s (OFGEM 2013). In the United States, 80 percent of power travels over privately owned transmission or distribution lines. New Zealand has a system similar to that in Ontario, with small LDCs (roughly 30 ) that are owned primarily by city councils or local consumer trusts. However, the LDC serving Auckland, the largest city, is 25 percent privately owned, and two of the other largest LDCs have been sold to institutional investors. In all cases, where an investor-owned utility operates a distribution network, it is accompanied by a price-setting regulator to protect consumers. Alberta and Ontario already have independent agencies regulating private-sector electricity distributors.

Ontario has the potential for cost savings through LDC consolidation that would be shared between owners and ratepayers. Previous efforts from Ontario governments have tried to force shotgun-marriage-type mergers between government-owned LDCs. There are likely to be few economies of scale from these forced consolidations (Fyfe, Garner, and Vegh 2013). Instead, voluntary consolidation through private-sector ownership is more likely to realize synergies. The big question is whether the government should decide which distribution companies should merge. Probably not: investors, whoever they are, 
are usually best placed to make those decisions. Private companies, in a freed-up ownership market, would bear the consequences of poor choices but reap some of the rewards of good mergers.

Why have the sales not happened? Municipalities have hesitated to sell LDCs to private companies because of the provincial transfer and departure tax system. In the 1990s, when Ontario gave municipalities electricity assets, some of the associated debt was considered unsupportable by LDCs and placed in the Ontario Electricity Finance Corporation as stranded debt. Municipally owned LDCs currently make payments in lieu (PILs) of taxes to their provincial government equivalent to what their corporate income-tax liability would be. PILs paid by LDCs are devoted to reducing this debt. When sold, these LDCs would begin paying corporate income tax, which in part would flow to the federal government and not the province. To protect this revenue stream, the province assesses a transfer and departure tax on municipal LDCs that become subject to the corporate income tax.

The transfer tax system is bewildering. The bottom line is that a private company that wants to buy an electricity utility in Ontario faces a steep tax. It must pay a tax of up to one-third of the value of any purchase of a municipal utility. That cost has made it all but impossible for private companies, as opposed to government-owned ones, to buy municipal electrical utilities (see Fyfe, Garner, and Vegh 2013).

Before embarking on a consolidation program, Ontario should create a level field for private and public buyers by cutting the taxes on sales of electrical utilities. By mid-2018 the province had made only half-measures to address this problem. In the 2015 Ontario budget, the government reduced the transfer tax for 2016 to 2018 to 22 percent for LDCs with more than 30,000 customers and eliminated it for smaller utilities, down from 33 percent. It also exempted capital gains from the departure tax. These taxes will revert back to 
higher levels on December 31, 2018. Although the Ontario LDCs are worth $\$ 11-\$ 15$ billion, the province would capture $\$ 1.8-\$ 2.5$ billion in tax, leaving municipalities with $\$ 9-\$ 12.5$ billion. For this reason, the provincial tax poses a significant barrier to any sale.

To address this problem, the federal government should provide a one-time bonus to the provinces equal to the present value of anticipated federal corporate taxes for any LDC sold to the private sector. As a condition of sale, the proceeds must be reinvested in qualifying infrastructure projects. The federal government isn't getting any tax revenue anyway, so it has nothing to lose. Ontario should do the same - exempting municipalities entirely from transfer and departure taxes - if the proceeds of a sale are reinvested in qualifying infrastructure projects.

The barriers to any sale are less severe in Alberta. Enmax and EPCOR make PILs into the Balancing Pool, a provincial organization that manages power-generation purchase agreements. Any annual surplus is distributed to consumers as a bill rebate. The impact of these PILs on consumer electricity bills is small, representing an average of 6 percent of the consumer rebate paid by the Balancing Pool. If Calgary and Edmonton sold their LDCs, these PILs - averaging $\$ 17$ million per year since 2012 - would flow to the provincial and federal governments. To make sure that any sale to private investors does not increase electricity prices, the federal and Alberta governments should remit incremental tax revenues from LDC sales to prevent any adverse impact on consumers.

The key takeaway is that cities in Ontario and Alberta could sell equity stakes in local public infrastructure to institutional investor and use the proceeds to invest in new infrastructure. They can reinvest that money alongside investors or in a P3 model in userfee-financed infrastructure, or in projects without sufficient revenues that investors would not pursue. 


\section{How Cities Can Use the Canada Infrastructure Bank to Build Better ${ }^{29}$}

Asset recycling is one way of getting more out of municipal infrastructure. Private infrastructure funds can also help build more and better new infrastructure. Canada has a new federal institution to do exactly that: the Canada Infrastructure Bank. If done right, delivering large infrastructure projects through the proposed bank has the potential to significantly improve the effectiveness of infrastructure investment in Canada's cities. It could accelerate the pace of infrastructure development by encouraging the adoption of new funding sources - projects that are self-funding through user fees can proceed to construction more quickly. Moreover, charging users the true cost of the infrastructure they use reduces demand and lowers Canada's overall investment needs (see chapter 7).

The Canada Infrastructure Bank can also reduce the risk to taxpayers. Canadian governments have had difficulty accurately forecasting usage for new infrastructure - assuming they even make a forecast public. The bank has the potential to work with the private sector and with municipal governments to improve these forecasts (avoiding the cost for taxpayers of getting them wrong) and to rigorously adopt international best practice in project evaluation.

\section{What Is the Canada Infrastructure Bank?}

In mid-2017, the federal government passed legislation to create the Canada Infrastructure Bank. This bank is meant to invest and attract private-sector investment in Canadian infrastructure projects that will generate revenue. The bank was positioned as one way to solve the problem of Canadian pension plans not investing in infrastructure projects at home (see above). This move was a very positive development from initial visions for the infrastructure bank which relied on using the federal government's lower interest costs, compared to those for cities, to reduce the apparent costs of financing

29 This section draws heavily on the text from Robins (2017b). 
new infrastructure projects. Such savings, however, would have been an illusion (see above).

The bank is receiving $\$ 35$ billion in public support. This expenditure requires government oversight and accountability on how the money is used: allocating resources among regions, selecting projects, and balancing the tradeoffs among competing priorities. However, the political process is less well suited for the detailed negotiations required to create a partnership agreement with the private sector. If the government sticks only to laying out the broad priorities and leaving the professionals at the bank to finalize transactions, it can be transformative for new investment.

How the Canada Infrastructure Bank Can Improve Canadian Infrastructure

Canadian governments have announced substantial infrastructure investment agendas. These investments will need to be made wisely - selecting the right project designs, optimizing the tradeoff between benefits and costs, and prioritizing higher-return projects. The bank, working with private investors, has an important role to play in ensuring that Canadians feel confident the right projects are being advanced.

Governments should ensure they are investing in the right projects with the highest long-run returns, not necessarily the shovel-ready ones, by conducting a rigorous analysis of all major investments. They should set out the expected project costs and benefits in the business cases they produce justifying the proposals, submit those estimates to close scrutiny, and proceed only with those projects that are likely to maximize benefits - analyzing the appropriateness of going ahead with a project before determining how to procure it.

Despite the huge amounts of public money put into major infrastructure, it is astonishing how little clear and public scrutiny happens with investment decisions. In a review of more than 20 
major public transit projects in Canada's three largest urban areas, Iacobacci (2017) finds that in only six cases was there evidence that the projects attained break-even or net positive benefits; in four cases there was no evidence suggesting the project created net positive value; and the rest had no business-case documents in the public domain.

Business cases should not be treated as rubber stamps that come after governments have already committed to building projects. Indeed, the economic benefits or low costs that policymakers initially attribute to a project often do not hold up under the scrutiny of preparing a business case. A comprehensive analysis of Swedish infrastructure business cases for transportation projects showed that an initial list of projects under consideration included many in which the costs were higher than the benefits, and a large number of projects - even disregarding the investment costs - harmed society as a whole and had a negative benefits-to-costs ratio (Eliasson and Lundberg 2012).

This problem is not restricted to Canada. Bent Flyvbjerg and Cass Sunstein (2016) examined 2,062 global infrastructure projects and found that the cost-benefit ratio was "typically overestimated by 50 to 200 percent, depending on project," and that this information is "so misleading as to be worse than worthless, because decisionmakers might think they are being informed when in fact they are misinformed." Flyvbjerg, Bruzelius, and Rothengatter (2003) found evidence that project promoters have systematic optimism bias in their forecasts, leading to optimistic estimates instead of re-evaluations of whether projects are worth the money.

When the private sector is asked to invest in a project - and bear the risk of changing costs and revenues - another independent voice is added to comment on the accuracy of cost and usage estimates. This new perspective would provide decision-makers at all levels with additional information on the likely outcomes. The 
scrutiny is valuable, however, only if it feeds into decision-making processes, helping politicians at all levels to prioritize projects.

The bank can improve the quality of the project selection process by subjecting estimated costs and benefits to close scrutiny through private-sector capital. Global transportation projects have shown demand forecasting error greater than $+/-20$ percent on 45-85 percent of projects, depending on the study. The review of 10 large Canadian transportation projects by Robin (2017b) suggests that similar optimism pervades demand forecasts in Canada. On average, demand was 17 percent below forecast, and for the eight projects where governments fully bore demand risk, demand averaged 33 percent below forecast. Involving private capital should improve demand forecasting by increasing accountability for the estimates. Of these ten projects, the only two that saw demand exceed forecasts were those where some portion of demand risk was transferred to the private sector - Vancouver's Canada Line rapid-transit project and Quebec's Autoroute 30 project. A private-sector investor has a substantial investment riding on the accuracy of the demand forecast, so has ample incentive to evaluate the forecast more carefully.

An investment manager who frequently makes bad investment decisions will not remain an investment manager for long. Similar accountability does not exist for publicly managed projects. Without publicly available data on how projects perform against forecasts, it is impossible to hold politicians and public-sector managers accountable for their decisions. If the bank is unable to attract private-sector investment to a project-revenue forecast, the government should probably re-evaluate its estimate of likely usage of the project along with its decision to proceed.

Time will tell the effectiveness and perception of the bank. If implemented properly, however, and cities do their part to embrace the user-fee financed projects that the bank is mandated to support, 
it has the potential to dramatically improve the efficacy of our infrastructure investment decisions.

\section{Delivering More and Better Infrastructure in Canadian Cities}

Canadian cities need more and better infrastructure. The infrastructure cities have built has often been more expensive than necessary because of an insistence by many not to use private infrastructure providers. A large amount of the infrastructure Canadian governments do own - particularly electricity infrastructure - doesn't make sense for cities to hold. Cities - as well as electricity users - in Alberta and Ontario would be better off getting out of the electricity game and using money from a sale to build the kinds of assets taxpayers need to own.

Governments across Canada need to do more to foster the conditions for private investment in infrastructure. Some types of infrastructure, such as water or electricity distribution, could easily become monopoly providers if governments got out of these businesses and private companies took over. The result could be higher prices, worse service, or both. In these cases, the policy solution is to introduce a regulator. Where necessary, the provinces should create independent regulatory bodies to oversee infrastructure assets. These bodies would ensure that their owners, either government-owned corporations or institutional investors, act in the public interest ahead of private profit and for long-term sustainability.

Cities should look to get private money into more than existing assets: they should also be looking at how to invest alongside private investors to build new infrastructure. Help is on the way from Ottawa. The federal government recently announced plans to create an infrastructure bank that it would initially bankroll, but with a mandate to foster institutional investment capital for new public infrastructure. Done well, attracting private capital through the bank has the potential through intelligent risk transfer to improve 
the scrutiny of project proposals, accelerate the pace of project development, and deliver projects more cost effectively. Canadian cities should work with the bank and with private investors to catalyze the use of user fees as a funding source beyond tax revenues, eliminating the overuse that comes with infrastructure priced below its cost and allowing high-value projects to proceed faster. 

PART THREE The Cost of Housing 



\section{Chapter 9}

\section{The High Cost of High Home Prices}

The cost of housing increased dramatically between 2009 and 2016 in some of Canada's largest cities. In Toronto and Vancouver, prices for single-family houses increased, respectively, by over 60 percent and 80 percent between 2007 and 2016. With measures such as federal mortgage policy and taxes on foreign buyers, most government policies for these two cities focused on curtailing the demand for housing.

The story on house prices has been very different in other cities. Prices increased only modestly in Montreal and Ottawa from 2007 to 2016. In Edmonton and Calgary, despite booming economies in both cities for most of that period, prices consistently came down from 2007 peaks. What is the explanation? Evidence from around the world consistently shows that government policies limiting the supply of housing are among the key causes of higher house prices. 
Restrictions on housing supply hinder the efficiency of the housing market. Delays in building what people demand result in shortages and, therefore, higher prices. Numerous studies (Glaeser, Gyourko, and Saks 2005; Cheshire and Hilber 2008) have established that a well-functioning housing market results in the market price of housing being close to the feasible cost of constructing it. If prices exceed this construction cost, it is often due to excessive regulations that inhibit new construction and create an artificial shortage.

Some recent Canadian-specific research has found a persistent gap between the cost of building new housing and its market price in major Canadian census metropolitan areas (CMAs, which are statistical amalgamation of various municipal governments that form a single labour market in a broad region). ${ }^{30} \mathrm{~A}$ few specific policies are suspected of restricting housing supply and driving up the cost of housing (see chapter 10) - in particular, development charges (see chapter 11). First, however, we will focus on the broad economic costs, both abroad and in Canada, of supply constraints.

\section{Housing Supply Restrictions and Prices}

Many studies have investigated the causes and effects of housing regulations around the world, and we summarize them here. ${ }^{31}$ Strict building regulations often emerge from communities in which land is scarce because of geographical constraints or a large amount of existing development (Hilber and Robert-Nicoud 2013; Saiz 2010). Although governments do not control most geographical barriers to development, they control housing regulations.

Once people purchase a home, they sometimes have strong incentives to prevent new homes from being built or new developments from changing the character of the neighbourhood in which they purchased. New homes create competition when existing

30 This chapter is drawn from the first half of Dachis and Thivierge (2018).

31 This discussion is based on the review by Gyourko and Molloy (2015). 
homeowners put their houses up for sale. Competition lowers the potential rate of return on investment in housing - the largest asset in many households (Fischel 2001). As a result, existing homeowners often support local government policies such as zoning regulations that restrict new development, resulting in NIMBYism - "not in my back yard.”

\section{The Effect of Land-Use Regulation on House Prices}

The vast majority of studies on housing regulations find that increasing the strictness of building regulations increases housing prices by limiting the growth of housing supply (Gyourko and Molloy 2015). Another study proves that increasing the time to approve subdivisions across U.S. cities by one month led to a reduction in building permits by 10 percent (Mayer and Somerville 2000). In a study of English cities, Hilber and Vermeulen (2016) show that house prices would fall by around 25 percent if the most restrictive region replicated the planning policies of the least restrictive.

U.S. cities with more regulations on housing supply had higher volatility in house prices (Malpezzi and Wachter 2005), and house-price bubbles during the 1980s and 1990s were more pronounced in cities with strict regulation (Glaeser, Gyourko, and Saiz 2008). Grout, Jaeder, and Plantinga (2011) find that the urban growth boundary (akin to a greenbelt) near Portland, Oregon, increases residential prices only in neighbourhoods where it constrains development, creating a nearby amenity of green space that buyers value.

\section{The Costs and Benefits of Land-Use Regulations}

Housing regulations have an economic cost beyond increasing home prices. Restrictions on supply in the largest urban areas mean fewer opportunities for people from elsewhere to live and work in the most productive cities. When people move from low- to high-productivity locations, they improve not only their own earning potential but 
that of others around them. If restrictions on supply make moving to high-demand areas too expensive, people languish in low-productivity regions and lower overall national economic growth. Cities with more people in them are more productive, and that leads to higher incomes (see chapter 7). But high housing costs eat into those higher incomes. Finding ways to keep cities growing but keeping house prices down through more construction allows cities to amplify the agglomeration benefits of having larger cities.

A study in the United States found that overly stringent land-use regulations in highly productive cities like New York or San Francisco prevented workers from relocating from low-productivity regions to high-productivity regions because of the gap in housing prices between regions. By not relocating, potential workers and people already in the high-productivity regions are economically worse off. The study showed that this factor alone slowed yearly economic growth between 1964 and 2009 by 0.3 percentage points per year and, in 2009, decreased the size of the U.S. economy by nearly 14 percent compared to what it would have been (Hsieh and Moretti 2015). Another recent study found that U.S. labour productivity would be 12 percent higher if all states moved halfway from their current level of zoning restrictiveness to that of the least restrictive state (Herkenhoff, Ohanian, and Prescott 2017).

Strict land-use regulations also harm individuals more directly by not allowing landowners to use their land for their most productive possible use. A U.S. study found that a one-third (approximately) increase in the strictness of local regulations eliminated about one-third of the potential economic use of the land (Turner, Haughwout, and van der Klaauw 2014).

Restrictions on housing development also inform one of the key modern economic debates: inequality. One study (Knoll, Schularick, and Steger 2017) has found that 80 percent of the increase in home prices across 14 advanced countries since the Second World 
War has been due to the increasing prices of land, with construction costs holding flat. This pattern was not true in previous recorded history. Rognlie (2015) shows that the increase in house prices since 1945 explains almost all the increase in the inequality of global wealth relative to income as documented by Piketty (2014).

Land-use regulations have at least one benefit: they internalize negative building externalities, such as pollution from industrial sites, resulting in residents having a cleaner environment in which to live. Land-use regulations such as greenbelts can maintain local amenities, including views of natural landscapes. These regulations generate social benefits that might be more important for certain localities than their costs (Turner, Haughwout, and van der Klaauw 2014; Glaeser, Gyourko, and Saks 2005). Severen and Plantinga (2017), for example, find that California's Coastal Act raised real-estate prices not through restricting supply but by generating amenities.

However, empirical and theoretical studies have generally found that the cost imposed by housing regulations in many cities largely outweighs the benefits provided by land-use regulation (Gyourko and Molloy 2015). Our analysis relates solely to the economic costs of supply restrictions (see below). Policymakers should weigh these costs against the benefits of building-restriction regulations before adding any additional regulations.

\section{The Gap between Building Costs and Prices in Canadian Urban Areas}

The Canadian evidence relating to restrictions on house building is limited: it is largely based on surveys of developers, and not on actual measures of policy. No studies have measured the effect of regulations on house prices, which we'll examine below (see chapter 10). One study collected developer viewpoints across 48 Canadian cities and found that longer approval timelines and greater uncertainty, along with a low degree of community support for development and high 
development costs, fees, and rezoning prevalence all decreased the supply of housing (Green et al. 2016). The Canadian Homebuilders' Association (2014) conducted annual surveys of member companies for their views of critical problems. The top national concerns for many years, especially in Ontario, were high development charges as well as the shortages and high prices of land on which to build.

We now turn to an estimate of the broad economic cost of restrictions on new housing development for all major Canadian metropolitan areas. Next, I will use detailed data from Ontario municipalities to identify the specific barriers to housing development in that province (see chapter 10).

\section{The Cost of Building Restrictions Across Canada}

In any competitive market without barriers to entry, regardless of the product being sold, a basic prediction of economic theory is that the overall market price for that good will equal its marginal cost of production. Applying that theory to the Canadian housing market, the uninhibited and competitive market price for an average new single-detached home should equal the marginal cost to construct it (Glaeser, Gyourko, and Saks 2005). Imperfections in the market - such as few available transportation options to new land sites, additional costs of construction, shortage of land for development (for regulatory reasons, not natural geography), and a lack of competition among landowners or builders - create a gap between the marginal cost of construction and price. These imperfections in the market for developing land are the indirect evidence that barriers of some kind are driving up the market price of land and, therefore, of housing too.

\section{The Cost of Housing Construction (Excluding Land) in Urban Areas}

The marginal cost of constructing a single-detached house is primarily due to the costs of labour, materials, and time during its physical construction. These costs vary across the country. Statistics Canada reports the cost of construction of a single-detached home for each 
CMA in Canada - an amount that excludes the cost of land..$^{32}$ From 2007 to 2016 the average construction cost ranged from $\$ 200$ per square foot or less in places such as Abbotsford, B.C., cities in New Brunswick, and Kingston, Ontario, to between $\$ 300$ and $\$ 350$ per square foot in Vancouver, Edmonton, and Kelowna, B.C. The cost of construction in Edmonton was the highest of any city in Canada in the 2007-16 period, likely because of high labour costs in construction due to competition from high-paying construction jobs in the nearby oil sands. In urban areas with little open land available, developers will invest in higher-cost sites to redevelop, such as former industrial land that they must remediate.

Vacant landowners compete with each other to offer housing developers terms they will accept to build housing on the sites they own. In a market with many vacant plots available, landowners will compete fiercely to provide the land to developers, reducing the cost of land to the point at which they are indifferent whether to keep the land as is or sell it to developers. If land is scarce, as would result from restrictions on land use, traffic congestion, or a lack of transportation options that makes travelling to more distant land costly, those landowners who have land in areas that governments have allowed to be used for building will have market power. As a result, they can charge developers a higher price for land - a price that will be reflected in a higher cost for the homebuyer. Similarly, if regulatory delays for builders lengthen the time to build houses or if additional fees are applied by municipalities through development charges, the result will be a higher cost of housing up to the point that enough buyers will bear to make the development profitable.

Construction costs for single-detached dwellings are also inherently higher in urban areas with high demand or with

32 Individual municipalities report permit values to Statistics Canada. Although each municipality may collect data slightly differently, both Statistics Canada and the provincial financial reporting guide in Ontario advise cities to report only on physical construction costs. 
hard-to-replicate natural amenities such as waterfront views. Vancouver and Toronto, two urban areas with high demand, both had construction costs above $\$ 350$ per square foot in 2016, ranking them second and fourth, respectively, among Canadian metropolitan areas. Builders develop land in high-demand urban areas more intensively, providing either higher-quality homes or putting more homes in a given area, thereby increasing construction costs per square foot. The same effect will occur in areas with local amenities, such as waterfront properties: in an open housing market, taller buildings will rise in high-demand areas to house more people looking to live near the amenity. These taller buildings would become substitutes for single-detached housing, expanding to a point that keeps the cost of housing near the local amenity at the marginal cost of construction in a market without barriers to building.

The marginal cost of construction for condominiums or apartments is the cost to developers of adding one more floor to a building. In economic terms, a single-detached home is the marginal unit decision for single-detached homebuilders, while adding a whole floor is the marginal decision for multi-residential builders. As the price of land goes up, developers have an incentive to make land a smaller share of the cost of building homes. Hence, as land prices increase in urban areas with high demand, buildings get taller. Some types of mid-rise apartments may have declining costs per additional floor. If that is the case, builders would continue to build the tower taller as long as there was sufficient demand for the additional units. However, at some point in construction, each new floor added to a building makes the construction project more expensive.

For example, at a certain height, developers must switch from low-cost wood frames to more expensive concrete for structural strength, increasing the marginal cost of adding that extra floor. Another example is that, as buildings get taller and house or employ more people, there is a greater demand for elevators. As 
buildings become taller, the amount of floor space devoted to elevators increases to the point that the cost of adding another floor that would require an additional elevator would take away enough otherwise saleable floor space to make the marginal cost of the extra floor uneconomical.

As land prices go up, developers build taller buildings with an increasing marginal cost of construction up to the point that buyers are still willing to pay that price. However, in the case of government-imposed zoning restrictions on building height, which are common in Canadian urban areas, the marginal cost of construction of an additional floor would be less than the market clearing price - meaning there is a shortage of housing relative to a situation with no such regulation. Although we do not have data for multi-residential construction, this example shows the wisdom of viewing the marginal cost of constructing housing as what should determine the market clearing selling price of condominiums.

A number of U.S. and U.K. studies have found that the market for housing construction is highly competitive, with no dominant providers (Glaeser, Gyourko, and Saks 2005; Cheshire and Hilber 2008). The same is likely true in Canada. Indeed, according to Industry Canada data, more than 99 percent of the over 33,000 establishments in the residential buildings construction industry in Canada have fewer than 100 employees. However, this statistic is not a perfect measure of competition because a large share of production may be driven by a few large market players. The situation will also differ in each local area, but the assumption that the market for housing development is competitive is likely true. This means that any difference between the cost of supply and the market price for housing, especially over a long period, is likely due to persistent restrictions on access to new land. 


\section{Measuring the Barriers to Land Access in Canadian Urban Areas}

Following the method used by Glaeser, Gyourko, and Saks (2005), I undertook with Vincent Thivierge to estimate indirectly the broad cost of barriers to building more housing (see the appendix to this chapter for details). In that study we used the market price of all housing, including both newly built and the existing stock (Dachis and Thivierge 2018). However, newly built housing is often of a higher quality than the existing stock. Using the market price of newly built single-detached homes sold into each major Canadian urban area, as I do here, allows us to compare the production cost and the market price for houses of similar quality.

Further, the data I use include only the physical construction costs and exclude costs such as development charges, the price of land, and time costs for each development application. These data allow us to isolate the marginal cost of construction, following Glaeser, Gyourko, and Saks (2005), meaning that the gap between the market price of new homes and the physical construction cost is likely caused by barriers exclusively due to accessing land. In turn, the causes of these barriers could include congestion on roads making access to outlying areas difficult, delays in development, extra costs for developers, and financing long-term infrastructure through upfront development-charge costs on developers passed onto homebuyers. All these factors contribute to our measure of the construction-cost gap of barriers to land access.

Figure 9.1 presents the gap in dollars per square foot between the average CMA-level market price for new homes sold between 2007 and 2016 (according to the Canada Mortgage and Housing Corporation $[\mathrm{CMHC}]$ ) and the average physical construction cost for single-detached housing in Canada's 30 largest CMAs over the same years (according to Statistics Canada). To calculate the final cost of construction, we add a 25 percent markup to account for the fixed cost of land. This markup represents the inherent cost 
of providing some services to land - a cost that is largely invariant across urban areas. We also include a 17 percent markup to account for the profit margin of developers. To make our results comparable to those of others who use a similar methodology, both additions are identical to the assumptions made in Glaeser and Gyourko (2017).

For most CMAs, our cost measure, which is simply the difference between the building construction cost per square foot and the market price per square foot, is close to zero. This minimal difference is to be expected in a normally functioning municipal housing market. However, for a few CMAs such as Abbotsford, B.C., single-detached house prices exceed the construction cost of new units by $\$ 150$ per square foot or more. In Vancouver, the cost gap is $\$ 300$ per square foot (figure 9.1).

In some urban areas with very little new housing demand and little new housing construction, such as Windsor and London in southwestern Ontario, or Trois-Rivières and Sherbrooke in Quebec, the gap is negative. That result could reflect housing market imperfections or an excess supply of housing due to the durable nature of housing. It could also reflect variations in profitability in some regions if they are less competitive. Oshawa is an outlier in our analysis. It has a high cost of construction (similar to that in nearby Toronto) but a low sale price of new housing, leading to a negative construction gap.

Given that the supply side of markets can take time to adjust to shifts in demand, deviations of house prices from building costs could arise in a given CMA in a certain year even with no barriers to construction. However, persistent deviations of prices from construction costs are clearer signals of barriers to development in a CMA (Gyourko and Molloy 2015). The gap has been positive and rising for single-detached housing in both Toronto and Vancouver since 2007 , at over $\$ 200$ per square foot in Vancouver (figure 9.2). To use a striking example, the increase in the price of housing has little to do 

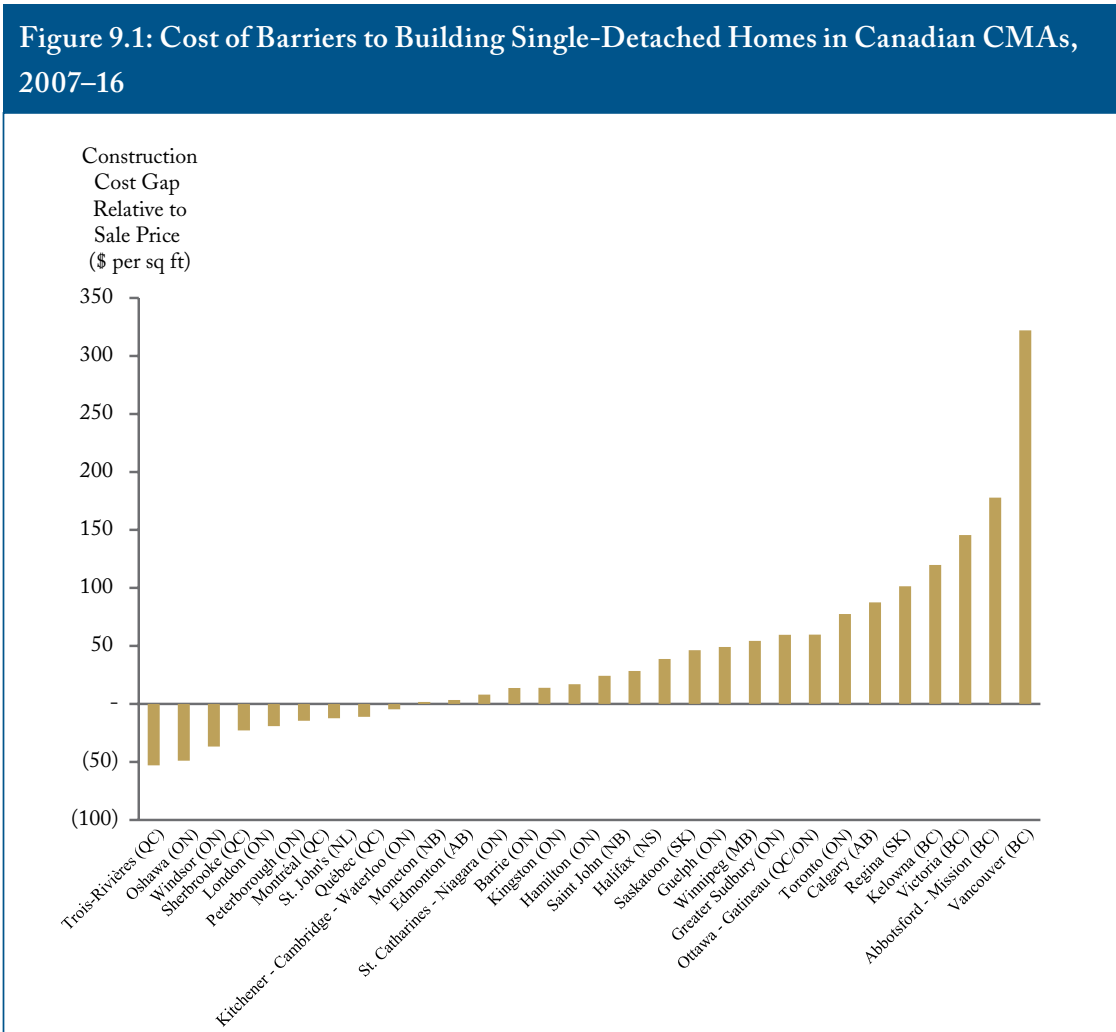

Note: All prices are in 2016 constant dollars. Average prices and costs are for the entire time period are weighted by the number of permits in each CMA per quarter. Source: Calculations from Dachis and Thivierge (2018) and from RPS, CMHC, and Statistics Canada data.

with increases in the per square-foot cost of construction, which did not increase nearly as much as house prices from 2007 through 2016 in Vancouver.

This result is similar to U.S. findings that show that real construction costs have increased by only one-third since the 1970s, but that residential land values quadrupled over the same period (Davis and Heathcote 2007). It is no surprise that Vancouver has 


\section{Figure 9.2: Cost of Barriers to Building Single-Detached Homes in the Five Largest CMAs, 2007-16}

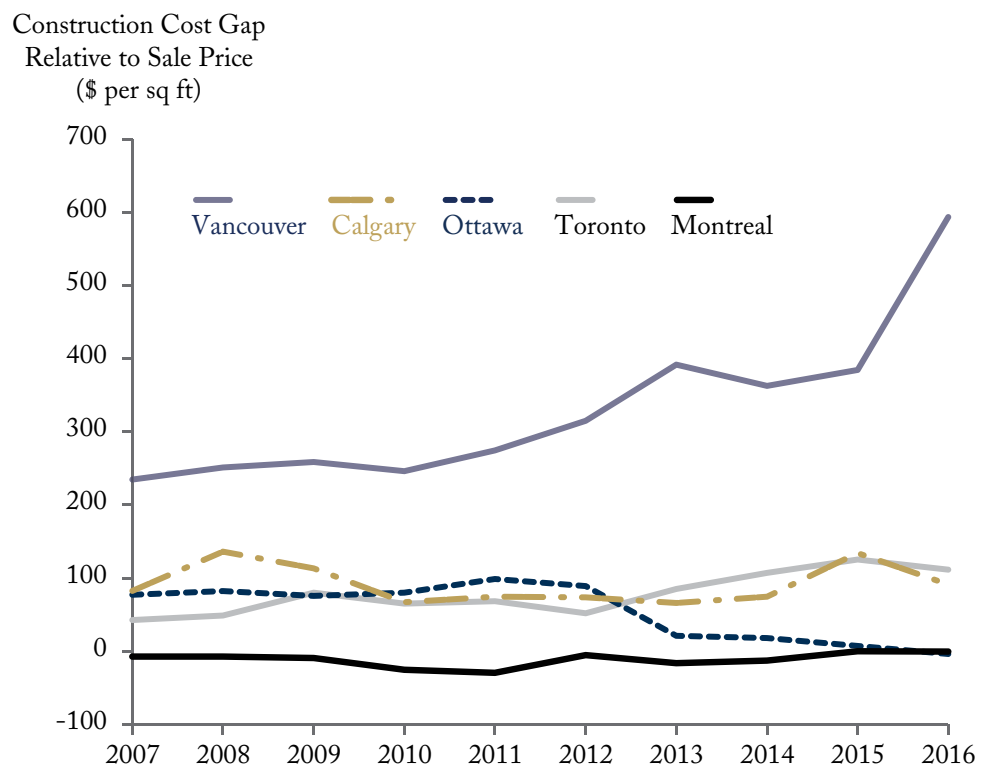

Note: All prices are in 2016 constant dollars. Annual average prices and costs are weighted by the number of permits in each CMA per quarter.

Source: Calculations from Dachis and Thivierge (2018) and from RPS, CMHC, and Statistics Canada data.

the highest barriers to new construction, as many municipalities throughout the region have adopted strict zoning rules that limit neighbourhood density. In contrast, the construction cost gap has been closing in Ottawa and has stayed around $\$ 0$ in Montreal since 2007. It has remained largely flat in Calgary too.

\section{The Cost of Barriers to Land Access in Canadian Urban Areas}

The Canadian results show that the regulatory burden now makes up around 50 percent of the cost of housing in the Vancouver area (table 9.1) and more than 20 percent in Toronto. In eight Canadian 
urban areas - Vancouver, Abbotsford, Victoria, Kelowna, Regina, Calgary, Toronto, and Ottawa-Gatineau - new homebuyers paid an average of an extra $\$ 230,000$ on a new house because of limits on new building. If there were no barriers to supply, developers would have produced, over the 2007-16 period, more housing further along their supply curve - and thus at a higher cost of production - to meet market demand. Vancouver's cost of housing restrictions are by far the largest in Canada, resulting in an extra cost of $\$ 600,000$ for the average new house, and are among the largest internationally as a share of market costs.

Using a similar methodology, though with the market price of the existing stock and not new units, other studies have estimated the regulation burden to be around 68 percent in Brussels, about 50 percent in Manhattan in 2000, approximately (Cheshire, Nathan, and Overman 2014), and as severe as 800 percent for U.K. office buildings (Cheshire and Hilber 2008). A new study from Australia found house prices to be 52-73 percent above marginal costs in Sydney (Kendall and Tulip 2018).

\section{Mind the Housing Cost Gap}

Barriers to development on housing have created huge gaps between the cost of building new housing and the market price. These gaps are substantial in a number of areas in British Columbia and across the Greater Toronto Area that have seen the largest run-up in prices. Other cities across Canada have seen construction costs stay in line with the price of housing, even in the face of booming economies, such as in Edmonton, Alberta. This contrast shows that barriers to building new homes are a major cause of higher house prices.

These barriers often stem from regulatory burdens, but they can also include factors such as congestion and a lack of transportation or access to developable land. These barriers account for around 50 percent of the cost of housing in the Vancouver area - an amount 


\begin{tabular}{|c|c|c|c|c|c|c|}
\hline CMA & $\begin{array}{l}\text { Average } \\
\text { Living } \\
\text { Size } \\
\text { (square } \\
\text { feet) }\end{array}$ & $\begin{array}{l}\text { Number } \\
\text { of Units } \\
\text { Created }\end{array}$ & $\begin{array}{l}\text { Restric- } \\
\text { tion Cost } \\
(\$ \text { per } \\
\text { square } \\
\text { foot })\end{array}$ & $\begin{array}{l}\text { Restric- } \\
\text { tion Cost } \\
\text { (percent } \\
\text { of cost) }\end{array}$ & $\begin{array}{c}\text { Average } \\
\text { new Sin- } \\
\text { gle-fami- } \\
\text { ly House } \\
\text { Price } \\
\text { (\$thou- } \\
\text { sands) }\end{array}$ & $\begin{array}{c}\text { Increase } \\
\text { in Cost } \\
\text { per New } \\
\text { House } \\
\text { (\$thou- } \\
\text { sands) }\end{array}$ \\
\hline $\begin{array}{l}\text { Ottawa - } \\
\text { Gatineau }\end{array}$ & 1,873 & 2,953 & 60 & 23 & 492 & 112 \\
\hline Regina & 1,302 & 875 & 101 & 28 & 473 & 132 \\
\hline Calgary & 1,737 & 5,449 & 88 & 24 & 631 & 152 \\
\hline Toronto & 2,161 & 10,640 & 78 & 22 & 751 & 168 \\
\hline Kelowna & 1,727 & 561 & 120 & 27 & 775 & 207 \\
\hline Victoria & 1,812 & 691 & 146 & 37 & 720 & 264 \\
\hline Abbotsford & 1,746 & 317 & 178 & 51 & 607 & 311 \\
\hline Vancouver & 1,999 & 3,524 & 322 & 50 & 1,298 & 644 \\
\hline \multicolumn{6}{|c|}{ Average of top-eight restrictive cities } & 229 \\
\hline \multicolumn{6}{|c|}{ Average of all Canadian cities } & 113 \\
\hline \multicolumn{7}{|c|}{$\begin{array}{l}\text { Note: All prices are in } 2016 \text { constant dollars. Average prices and costs for the entire period are } \\
\text { weighted by the number of permits in each CMA per quarter. } \\
\text { Source: Calculations from Dachis and Thivierge (2018) and from RPS, CMHC, and Statistics } \\
\text { Canada data. }\end{array}$} \\
\hline
\end{tabular}

equivalent to the cost of regulatory barriers that other studies have found for Manhattan, New York City. In Vancouver, the cost of housing restrictions is by far the largest in Canada, at $\$ 644,000$ for the average new house. In Canadian cities in which the market price of new housing is more than 20 percent higher than the cost of construction, we estimate that, because of the barriers to building 
more single-family houses, homebuyers paid an extra $\$ 229,000$ per new house between 2007 and 2016. Conversely, when prices are well below the cost of construction, as in a few Canadian cities and as American studies have shown in many cities, the discrepancy reflects an oversupply of housing, usually because of falling population while housing stocks remain durable. Both these examples - an excess and a dearth of housing - show that supply is a key driver of house prices.

Regulatory barriers to building new homes result in higher prices for existing homes as well. Policies that reduce the supply of new housing result in less competition in the resale market for existing homes, boosting their price. For that reason, current homeowners are often strong supporters of land-use regulations. In chapter 10 we'll examine the specific policies cities and provinces put in place that drive up house prices.

\section{Appendix}

For the data analysis reproduced in this chapter from Dachis and Thivierge (2018), we worked at the Census Metropolitan Areas (CMA) level, using the sale prices of single-detached new dwellings compiled by the Canada Mortgage and Housing Corporation (CMHC). The CMHC data allow us to isolate the average market price of new housing units - a price that is directly comparable to the average cost of construction of new housing in the same CMA.

Glaeser and Gyourko (2017) estimate the cost of barriers to construction for each city as the market price of housing $(\mathrm{P})$ minus the minimum profitable production cost (MPPC), with both expressed in per square-foot terms. The MPPC is $\mathrm{MPPC}=(\mathrm{CC}+$ $\mathrm{L}) * \mathrm{EP}$, where $\mathrm{CC}$ is the cost of construction, $\mathrm{L}$ is the cost of acquiring land, and EP is the margin that developers earn as profit.

For construction costs, we use the value of building permits and the number of new units created for single-detached dwellings 
by CMAs for the same period set out in Statistics Canada Cansim Series 026-0001. Statistics Canada reports building permit value from the CMA-wide total of its monthly Building and Demolition Permit Survey. Permit value is defined by Statistics Canada as "the value of the construction project as reported by the permit applicant or as estimated by the municipality." This value does not include renovation costs. The permit value closely reflects the structure construction cost.

We also compared our data to those from the Altus Group (2017), which produces cost per square-foot ranges for simple, single-detached wood-frame houses for nine CMAs. Those cost data are based exclusively on hard construction costs, assuming average quality finishes, and exclude regulatory costs. In all cases our construction costs are higher than the high end of that range - meaning, if we are overestimating construction costs, we are underestimating the cost of land access. We conduct our analysis on a per square-foot basis to make the metric for construction cost comparable to that for the market-price value.

We assume that new construction homes have the same average living space as existing single-detached homes as reported in Real Property Solutions (RPS) data. Also from RPS, we collected average square-foot size of single-detached dwellings of all homes in each CMA from 2007 to 2016. We compared the data for existing homes to less comprehensive data provided at a provincial level of the size of new homes from 2012 to 2014, as compiled by the Canadian Home Builders' Association (2012, 2013, 2014) from a survey of homebuilders. The square footage amounts are similar, giving us confidence in using the more detailed square-foot data from RPS.

We now need to make assumptions for $\mathrm{L}$ and EP. Glaser and Gyourko (2017) use "an industry rule of thumb that suggests land values are no more than 20 percent of the sum of physical construction costs plus land in a relatively free market with few restrictions on 
building." They state that this measure is based on an ad hoc survey of home builders and is one that has held true for nearly a decade since some of their original work. Vacant land sales are also rare in Canada. MCAP (2017) provides an estimate of lot values for a series of locations across Toronto. Between 2015 and 2017, land prices in all parts of Toronto were never above 20 percent of the total cost of housing, usually ranging around the 10-15 percent range. Further, land prices beginning in 2012 (when MCAP began this time series) were flat or declining from then to 2015 in most of Toronto. By using the 25 percent assumption of land costs, we are perhaps understating the costs due to housing supply barriers, and instead attributing the cost to higher-than-actual costs of land.

Glaeser and Gyourko (2017) calculate gross margins (EP) by inferring them from the overall rates of return from developers of between 9 percent and 11 percent. From that data, they estimate gross margins of 17 percent. Industry Canada data on residential construction profitability provide conflicting perspectives of whether Canadian developers are more or less profitable than those in the United States. The average gross margin in Canada for construction in 2016 is in this range, at 16.5 percent of total revenues. ${ }^{33}$

33 See https://strategis.ic.gc.ca/app/scr/app/cis/performance/rev/236 


\section{Chapter 10}

\section{The Causes of the High Cost of Housing}

Most Canadians have been closely watching house prices over the last decade. For homeowners, it's been exciting to see the value of their homes increase. But for those looking to enter the market in places like Toronto and Vancouver, they've watched with horror as owning a home has risen further out of reach. Economists have acted like detectives in a murder mystery, trying to pin the cause of ever-rising prices on a specific suspect. Some put it on foreign buyers; others, on interest rates. The list of accused is long.

In this chapter, I'll investigate how specific regulatory burdens - both provincial and municipal - are the key suspects behind the increase in house prices. Using detailed price and policy data for Ontario municipalities, I'll estimate how much the price of single-detached housing would fall if municipalities that impose above-average costs and barriers on housing development improved their performance to merely the current provincial average. The focus (as in chapter 9) will be on single-detached housing, which makes up more than half of all housing in Canada (see 2016 Census). 
The case is clear: policies that restrict the supply of housing are a major cause of the high prices. Development charges are a major cost to homebuyers. A lack of land available for housing is also driving up prices. The primary cause is not the Greenbelt but suburban municipalities, supported by certain provincial policies, which disable development on land between the existing urban boundary and the Greenbelt.

\section{Barriers to Building and High Housing Prices in Ontario Municipalities}

We have already examined the overall gap between the construction costs of houses and their price (see chapter 9). Data on construction costs are available only at the CMA level, which is an amalgam of various cities in a broad region. However, specific municipalities determine policies such as zoning rules, development charges, or other potential costs on housing. For the analysis used in this chapter, Vincent Thivierge and I collected detailed data on municipality-specific policies that might affect the price level of single-detached dwellings. ${ }^{34}$ I paired that with data on the price of single-family homes for almost all Ontario municipalities. My analysis focuses on single-detached house prices because we do not have price information on condominiums in a sufficient number of cities to conduct a similar analysis.

\section{What Are the Suspects in the Great Canadian Housing Debate?}

Although the analysis here is specific to Ontario municipalities, many of the same principles of zoning regulations, costs on builders, and other policies are similar in other provinces. Let's investigate the effect of five potential barriers on single-family house prices (see table 10.1 for a summary of the average and the worst municipality in Ontario on each metric):

34 This chapter reproduces material from the second half of Dachis and Thivierge (2018). 


\begin{tabular}{|c|c|c|c|c|}
\hline & 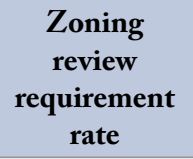 & $\begin{array}{c}\text { Average } \\
\text { development } \\
\text { charge }\end{array}$ & $\begin{array}{l}\text { Agricultural } \\
\text { share }\end{array}$ & $\begin{array}{l}\text { Greenbelt } \\
\text { share }\end{array}$ \\
\hline $\begin{array}{l}\text { Highest large-city } \\
\text { value }\end{array}$ & $\begin{array}{r}82 \% \\
\text { (Toronto) }\end{array}$ & $\begin{array}{r}\$ 66,380 \\
\text { (Vaughan) }\end{array}$ & $\begin{array}{r}49 \% \\
\text { (Hamilton) }\end{array}$ & $\begin{array}{r}80 \% \\
\text { (Caledon) }\end{array}$ \\
\hline $\begin{array}{l}\text { Province-wide } \\
\text { average }\end{array}$ & $34 \%$ & $\$ 31,367$ & $33 \%$ & $38 \%$ \\
\hline Years data reported & 2013-16 & $2012-16$ & $2005-13$ & 2005 \\
\hline $\begin{array}{l}\text { Number of } \\
\text { municipalities } \\
\text { reporting (province- } \\
\text { wide) }\end{array}$ & 286 & 95 & 298 & 97 \\
\hline \multicolumn{5}{|c|}{$\begin{array}{l}\text { Note: Agricultural and Greenbelt share is only for municipalities subject to the Growth Plan for } \\
\text { the Greater Golden Horseshoe (GGH). Large-city values are only from municipalities with 50,000 } \\
\text { residents or more within the area subject to the Growth Plan for the GGH. Province-wide average i } \\
\text { weighted by population of municipality. } \\
\text { Source: Calculations from Dachis and Thivierge (2018) and from Ontario Ministry of Municipal } \\
\text { Affairs data. }\end{array}$} \\
\hline
\end{tabular}

the share of single-detached-dwelling building permits that require a zoning review;

- the average development charge levied on a single-detached dwelling in a municipality;

- the share of each municipality's land that is zoned for agriculture;

- the share of each municipality's land that is designated for the Greenbelt (see figure 10.1); and

- whether a municipality is subject to the Growth Plan for the Greater Golden Horseshoe (GGH). 


\section{Figure 10.1: The Greenbelt and Growth Plan for the Greater Golden Horseshoe}

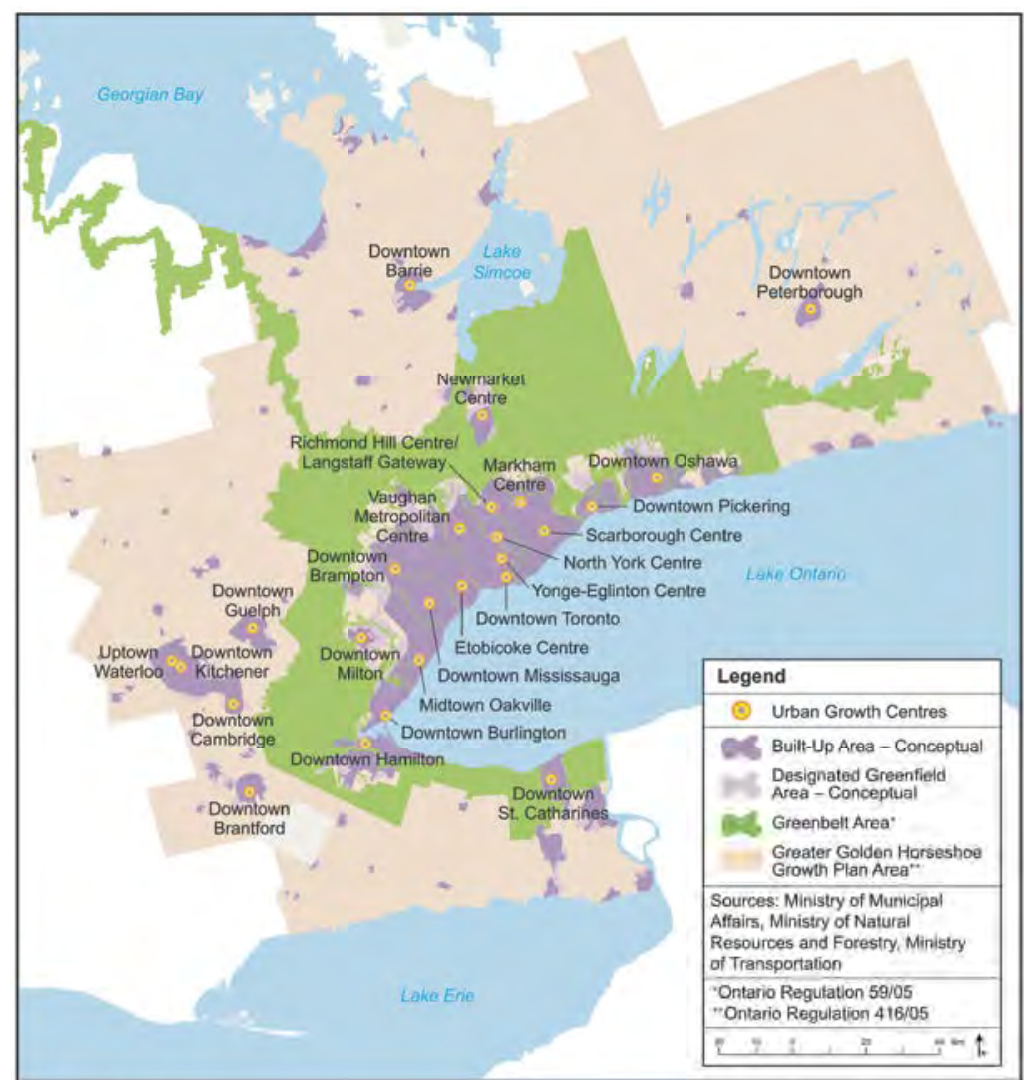

Source: Ontario Ministry of Municipal Affairs.

\section{Rezoning Requirements}

The Ontario Building Code specifies that once a developer submits an application for a single-detached dwelling that fits the existing zoning and applicable laws of a municipality, the municipality must either approve or reject it within 10 days. If a developer or a municipality believes a building permit application might not meet local 
zoning requirements, these permit applications are placed into a separate stream that is not subject to any time limit. Toronto has the highest share of permit applications subject to this review (82 percent, compared to 27 percent in the rest of the Greater Toronto Area [GTA]), and projects in this category undergo an extensive review. A municipality with an above-average number of housing developments subject to a review process is likely to see higher home prices.

\section{Development Charges}

Most major single-, upper-, and lower-tier municipalities levy a development charge on the developers of new buildings. The provincial Development Charges Act permits cities to enact a bylaw laying out these charges - a power some cities have taken up with gusto, others not at all. We calculate the average combined development-charge rate, which in Vaughan was in excess of $\$ 66,000$, compared to around $\$ 32,000$ for the other 94 municipalities that levy a development charge; in many other places, there is no development charge. A number of studies around the world show that higher development charges increase the price of housing and that they are an inefficient and inter-generationally unfair way of financing infrastructure (see chapter 11).

\section{Land Zoned for Agriculture, Not Housing}

Most Ontario municipalities track the amount of land within their municipal boundaries which has been zoned for agriculture. When municipalities have a large share of land dedicated to agriculture (such as Hamilton, which has about half its land zoned for agriculture), less land is available for greenfield housing construction (construction on undeveloped land, which is usually agricultural land). The resulting shortage of land leads to increases in home prices. It often takes many years even to attempt to rezone land designated for agriculture into land available for new housing. The uncertain and long rezoning process means that municipalities with a large share 
of land zoned for agriculture will likely see high house prices. This agricultural land share should limit residential development only in municipalities near the GTA subject to the Growth Plan for the GGH (see below).

\section{Greenbelt Land Use Restrictions}

The province of Ontario created the Greenbelt surrounding existing development in the GTA in 2005. The Greenbelt extends from the Niagara Region to surround the majority of the existing development to the north and east (figure 10.1). While some of the Greenbelt is parkland open to the public, much of it is agricultural land that has more in common with industrial land than green space. New development on Greenbelt land is heavily restricted. The Greenbelt includes both agricultural land and park space and represents as much as 80 percent of the area of the town of Caledon and 38 percent for the average GTA-area municipality.

\section{Regional Growth Plans}

In addition to the Greenbelt, the province of Ontario also has growth plans that apply to municipalities both inside and outside the Greenbelt (the beige shaded area of figure 10.1). Municipalities in these regions are required to approve a certain share of their homes within existing urban development boundaries (the dark purple areas of figure 10.1), and new developments outside the existing growth boundaries must be of a certain density (see Ontario 2017). Starting in June 2009, municipalities subject to the Growth Plan for the GGH were allowed to approve new developments outside their existing urban growth boundary only if the new developments met a densification target of at least 50 jobs or 50 residents per hectare. That's the kind of density one would see in a suburban 
neighbourhood with ample parking, but mostly three- or four-storey low-rise apartments. ${ }^{35}$ For comparison, in 2016 the City of Toronto had 43 residents per hectare, while Brampton had 22 residents per hectare. In addition, municipalities had to meet an intensification target that 40 percent of all new approvals needed to be within the existing urban growth boundary.

The province recently released a revised Growth Plan that will increase the densification target to 80 jobs or 80 people per hectare and require 60 percent of new development to be within existing growth boundaries (Ontario 2017). I expect the Growth Plan to have the largest upward effect on house prices in municipalities with a large amount of land zoned for agriculture.

\section{How to Calculate the Regulatory Causes of High Housing Prices in Ontario Municipalities}

To assess the economic cost of these policies, I calculate the relationship between the price of single-detached dwellings in each lower- and single-tier municipality in Ontario and the municipality's development cost and regulatory performance on each of these metrics. I use the average of each municipality's regulatory and land-use policies listed above for all years and compare that to 11 years of housing prices for that municipality, from 2005 through 2016. This regression analysis allows me, for example, to isolate how much prices in a municipality respond to the share of building permits that must go through a lengthy zoning review or are subject to high development charges, while holding constant other characteristics of that municipality, such as the income of its residents or the share of

35 See http://urbankchoze.blogspot.com/2015/04/why-is-montreal-so-muchmore-affordable.html 
land dedicated to agriculture. (See the appendix to this chapter for details. $)^{36}$

The first step to assessing the effect of supply constraints on prices is to control for factors that would influence the demand for housing. I control for annual income and annual household growth in each municipality and for other metropolitan area- and year-specific factors. I find a relationship between increasing development costs and delays and land-use limitations which leads to an increase in the overall cost of single-detached dwellings. Restrictions on building new homes ripple through the entire market, making the average existing home - not just new homes - in each municipality more expensive for the following reasons (after holding other possible policies and differences across cities constant; see appendix table 10.A1, column 4):

A municipality that puts all homes through a zoning review would make single-detached homes 5 percent more expensive than a municipality that did so for none. ${ }^{37}$

36 It's important to note that these kinds of policies have a chicken-and-egg, or endogeneity, problem: Which came first, the high house prices or the strict housing policies? People might decide to build higher-quality houses in places with strict zoning, which then causes demand to rise compared to areas with less zoning. To get around this problem, our method follows the methodology of Hilber and Vermeulen (2016), who show the effect of development and planning policies on house prices in the United Kingdom. They take the municipality average of each policy variable over the whole sample period - a method that limits the extent to which measures of zoning requirements are influenced by tighter requirements put in place after house prices increased. They also perform what is called an instrumental variable technique to control for potential reverse causality. Such a test gets around this chicken-and-egg problem by testing the relationship between a policy variable and zoning, but not house prices. Because they find that the results of development policy are the cause of higher house prices, and not the reverse, we do not replicate their instrumental variable approach.

37 While economically significant, this result is not statistically different from zero in our main results, falling just short of statistical significance at the 10 percent level. 
- Every 10 percent increase in development charges on a new single-detached dwelling results in homes increasing in price by 0.45 percent. ${ }^{38}$

- A municipality with half its land in the Greenbelt would have 14 percent higher prices than a municipality with no land in the Greenbelt. (The Ottawa Greenbelt is not included in the Greenbelt here.)

- A municipality subject to the Growth Plan with half its land zoned for agriculture would have home prices about 6 percent higher than a municipality with the same share of land zoned for agriculture not subject to the Growth Plan.

- A municipality subject to the Growth Plan with half its land zoned for agriculture would have homes 6 percent more expensive than a municipality also subject to the Growth Plan with no land zoned for agriculture. ${ }^{39}$

\section{How Much Barriers on Development Increase Housing Costs in Ontario}

Taken together, what do these results mean in practice for major Ontario municipalities? I estimate how much single-detached dwelling prices would fall if each municipality that had above-average barriers to supply lowered them to be at the current provincial average (as reported in table 10.1). For example, Toronto requires that over 80 percent of all building permits go through a zoning review. I estimate what the change in prices would be if it along with every other municipality with an above-average zoning review rate - required reviews only at the provincial average rate of

38 This conclusion assumes that interest rates for a conventional mortgage are at 4.5 percent. It results from an interaction variable produced by interest rates and the development charge in each municipality. See the appendix to this chapter for details.

39 This analysis is based on an interaction of the Growth Plan with the shareof land in each municipality that is zoned for agriculture. See the appendix to this chapter for details. 
34 percent. Similarly, Vaughan requires, on average, over $\$ 66,000$ in development charges. I show what the change in housing costs would be if development charges there - along with other cities with high development charges - were around the current provincial average of $\$ 31,000$.

I estimate the effects for the cities of Ottawa, Toronto, and Hamilton and for individual GTA lower-tier municipalities, and I create a regional municipality-wide weighted average for Durham, York, Peel, Halton, and Niagara regions using the policies in place as of 2016 (table 10.2). Cutting development charges to the provincial average would have the largest effect in York and Peel regions, reducing single-detached home prices by around $\$ 52,000-\$ 78,000$. One of the single empirically largest increases in single-detached home prices due to regulations (an increase that is not statistically significant from zero) is in Toronto, because of its high rate of subjecting single-detached building-permit applicants to a zoning review. This cost is caused by the high price of housing (even a small percentage increase results in a high absolute increase) and the high rate that Toronto subjects housing to rezoning. Cutting the zoning review rate to the provincial average would reduce single-detached home prices in Toronto by $\$ 27,000$. The total benefit of reducing development and zoning costs by half would be in excess of an $\$ 80,000$ reduction in single-detached dwelling prices in York Region and nearly $\$ 75,000$ in Toronto.

We estimate the effect if municipalities increased the amount of land available for development to be in line with the average municipality in the province. We also estimate the effect if each city lowered the amount of agricultural and Greenbelt land to the provincial average, and if it no longer was subject to the Growth Plan (table 10.3). In Niagara Region and Hamilton, for example, municipalities there have a large share of land zoned for agriculture. Allowing development on a portion of either parkland or agricultural 
land in a municipality dedicated for the Greenbelt could reduce single-detached dwelling prices by around $\$ 50,000$ in Hamilton and $\$ 25,000-\$ 30,000$ in York and Halton regions. Loosening the restrictiveness of the Growth Plan would have the greatest effect on municipalities with a large share of land zoned for agriculture: over $\$ 20,000$ in Hamilton and in Durham and Niagara regions.

However, a far greater amount of undeveloped land is not covered by the Greenbelt, as well as land yet to be developed between the existing urban growth boundaries and the Greenbelt. However, much of this land is not zoned in a way that allows for housing development. Zoning, not necessarily developing, more of the agricultural land in a municipality to make it available for residential use - while keeping the size of the Greenbelt constant - would, as of 2016, reduce home prices by as much as $\$ 15,000$ in Hamilton and \$13,000 in Niagara Region and other parts of the Greater Golden Horseshoe beyond the Greenbelt. Increasing the amount of land available for development and relaxing the Growth Plan would have the greatest effect in outlying areas of the Greater Golden Horseshoe. Taken together, loosening restrictions on land availability for new single-detached housing could reduce home prices by $\$ 90,000$ in Hamilton and around $\$ 45,000$ in Durham, York, and Niagara regions.

A modest increase in land availability for housing development, along with cutting development and zoning costs to the provincial average, would reduce the price of single-detached housing by over $\$ 70,000$ in Toronto and in Peel and Durham regions, $\$ 90,000$ in Halton Region, over $\$ 100,000$ in Hamilton, and nearly $\$ 125,000$ in York Region (figure 10.2). Province-wide, increases in housing costs are due about equally to restrictions on land development and development costs and delays, for a total cost of $\$ 45,000$.

What are the total economic costs of these restriction policies? Multiplying the provincial average restriction by the total 


\begin{tabular}{|c|c|c|c|c|c|c|}
\hline \multirow{4}{*}{ Region } & \multirow[b]{2}{*}{$\begin{array}{c}2016 \\
\text { average } \\
\text { single- } \\
\text { family } \\
\text { dwelling } \\
\text { price }\end{array}$} & \multicolumn{2}{|c|}{$\begin{array}{l}\text { Reduction in price if } \\
\text { municipalities ... }\end{array}$} & \multirow[b]{2}{*}{$\begin{array}{c}\text { Total } \\
\text { reduction } \\
\text { in costs }\end{array}$} & \multirow[b]{2}{*}{$\begin{array}{c}\text { Price } \\
\text { with re- } \\
\text { strictions } \\
\text { reduced }\end{array}$} & \multirow[b]{2}{*}{$\begin{array}{l}\text { Restric- } \\
\text { tions as } \\
\text { share } \\
\text { of SFD } \\
\text { price }\end{array}$} \\
\hline & & $\begin{array}{c}\text { Had pro- } \\
\text { vincial } \\
\text { average } \\
\text { devel- } \\
\text { opment } \\
\text { charges }\end{array}$ & $\begin{array}{c}\text { Had pro- } \\
\text { vincial } \\
\text { average } \\
\text { zoning } \\
\text { approval } \\
\text { rate* }^{*}\end{array}$ & & & \\
\hline & $\begin{array}{l}\text { Actual } \\
\text { price }\end{array}$ & \multicolumn{3}{|c|}{ Reduction in price } & $\begin{array}{l}\text { Predicted } \\
\text { price }\end{array}$ & (percent) \\
\hline & \multicolumn{5}{|c|}{ (\$thousands) } & \\
\hline $\begin{array}{l}\text { Durham } \\
\text { Region }\end{array}$ & 554 & -27 & -3 & -29 & 525 & 5 \\
\hline York Region & 969 & -78 & -3 & -81 & 888 & 8 \\
\hline Toronto & 943 & -47 & -27 & -74 & 869 & 8 \\
\hline Peel Region & 714 & -52 & 0 & -52 & 662 & 7 \\
\hline $\begin{array}{l}\text { Halton } \\
\text { Region }\end{array}$ & 771 & -49 & -3 & -52 & 719 & 7 \\
\hline Hamilton & 436 & -13 & 0 & -13 & 423 & 3 \\
\hline $\begin{array}{l}\text { Niagara } \\
\text { Region }\end{array}$ & 319 & -2 & -1 & -4 & 315 & 1 \\
\hline $\begin{array}{l}\text { Waterloo } \\
\text { Region }\end{array}$ & 414 & -9 & 0 & -9 & 405 & 2 \\
\hline $\begin{array}{l}\text { Rest of } \\
\text { GGH }\end{array}$ & 393 & -8 & -3 & -11 & 382 & 3 \\
\hline $\begin{array}{l}\text { Rest of } \\
\text { Ontario }\end{array}$ & 291 & -2 & -1 & -2 & 289 & 1 \\
\hline \multicolumn{7}{|c|}{$\begin{array}{l}\text { *Approval rate is not statistically significant at the } 10 \text { percent level. } \\
\text { Note: Totals are weighted from each lower-tier municipality by its } 2016 \text { stock of single-detached } \\
\text { dwellings to calculate regional totals. } \\
\text { Source: Calculations from Dachis and Thivierge (2018) and from Ontario Ministry of Municipal } \\
\text { Affairs, RPS, and Statistics Canada data. }\end{array}$} \\
\hline
\end{tabular}




\begin{tabular}{|c|c|c|c|c|c|c|c|}
\hline \multirow{4}{*}{ Region } & \multirow[b]{2}{*}{$\begin{array}{c}2016 \\
\text { average } \\
\text { single- } \\
\text { family } \\
\text { dwelling } \\
\text { price }\end{array}$} & \multicolumn{3}{|c|}{$\begin{array}{l}\text { Reduction in price if } \\
\text { municipalities ... }\end{array}$} & \multirow[b]{2}{*}{$\begin{array}{l}\text { Total } \\
\text { reduc- } \\
\text { tion in } \\
\text { costs }\end{array}$} & \multirow[b]{2}{*}{$\begin{array}{l}\text { Price } \\
\text { with } \\
\text { restric- } \\
\text { tions } \\
\text { reduced }\end{array}$} & \multirow[b]{2}{*}{$\begin{array}{l}\text { Restric- } \\
\text { tions as } \\
\text { share } \\
\text { of SFD } \\
\text { price }\end{array}$} \\
\hline & & $\begin{array}{c}\text { had pro- } \\
\text { vincial } \\
\text { average } \\
\text { share of } \\
\text { land in } \\
\text { Green- } \\
\text { belt* }\end{array}$ & $\begin{array}{l}\text { were not } \\
\text { sub- } \\
\text { ject to } \\
\text { Growth } \\
\text { Plan }\end{array}$ & $\begin{array}{l}\text { had pro- } \\
\text { vincial } \\
\text { average } \\
\text { share } \\
\text { of land } \\
\text { zoned } \\
\text { for agri- } \\
\text { culture* }\end{array}$ & & & \\
\hline & $\begin{array}{l}\text { Actual } \\
\text { price }\end{array}$ & \multicolumn{4}{|c|}{ Reduction in price } & $\begin{array}{l}\text { Predict- } \\
\text { edprice }\end{array}$ & $\begin{array}{l}\text { (per- } \\
\text { cent })\end{array}$ \\
\hline & \multicolumn{6}{|c|}{ (\$thousands) } & \\
\hline $\begin{array}{l}\text { Durham } \\
\text { Region }\end{array}$ & 554 & -16 & -23 & -6 & -45 & 510 & 8 \\
\hline $\begin{array}{l}\text { York } \\
\text { Region }\end{array}$ & 969 & -30 & -14 & -1 & -44 & 925 & 5 \\
\hline Toronto & 943 & 0 & 0 & 0 & 0 & 943 & 0 \\
\hline $\begin{array}{l}\text { Peel } \\
\text { Region }\end{array}$ & 714 & -8 & -7 & -2 & -17 & 698 & 2 \\
\hline $\begin{array}{l}\text { Halton } \\
\text { Region }\end{array}$ & 771 & -26 & -13 & 0 & -39 & 732 & 5 \\
\hline Hamilton & 436 & -49 & -27 & -15 & -91 & 345 & 21 \\
\hline $\begin{array}{l}\text { Niagara } \\
\text { Region }\end{array}$ & 319 & -12 & -20 & -13 & -45 & 274 & 14 \\
\hline $\begin{array}{l}\text { Waterloo } \\
\text { Region }\end{array}$ & 414 & 0 & -14 & -9 & -24 & 391 & 6 \\
\hline $\begin{array}{l}\text { Rest of } \\
\text { GGH }\end{array}$ & 393 & -2 & -16 & -13 & -31 & 362 & 8 \\
\hline $\begin{array}{l}\text { Rest of } \\
\text { Ontario }\end{array}$ & 291 & 0 & 0 & -2 & -3 & 289 & 1 \\
\hline \multicolumn{8}{|c|}{$\begin{array}{l}\text { *Share of land zoned for agricultural land has a statistically significant effect on housing prices } \\
\text { only in municipalities subject to the Growth Plan. The effect of the Greenbelt land share is not } \\
\text { statistically significant at the } 10 \text { percent level. } \\
\text { Source: Calculations from Dachis and Thivierge (2018) and from Ontario Ministry of Municipal } \\
\text { Affairs, RPS, and Statistics Canada data. }\end{array}$} \\
\hline
\end{tabular}




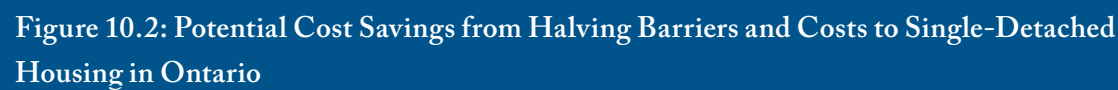

Additional

Cost on

Single-Family

Home

(thousand

dollars)

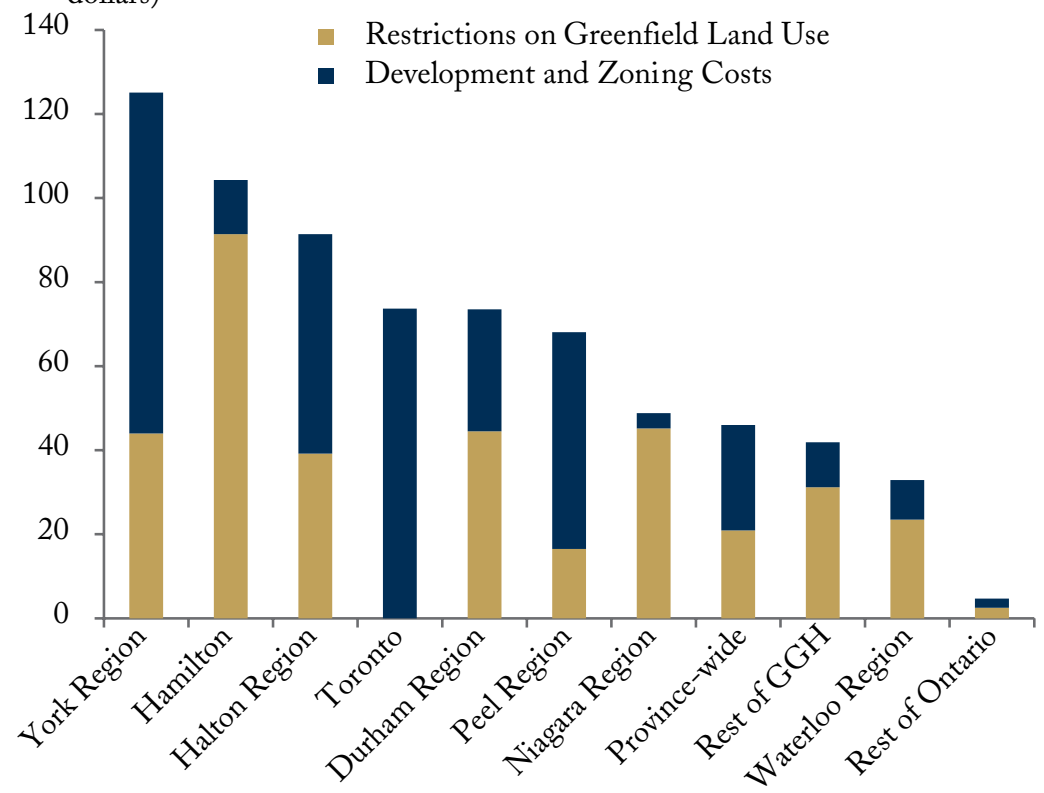

Source: Calculations from Dachis and Thivierge (2018) and from Ontario Ministry of Municipal Affairs, RPS, and Statistics Canada data.

stock of single-detached homes produces staggering totals. The largest total benefit would be in reducing development charges, which would reduce the total cost of housing in the province by $\$ 57$ billion. Relaxing the Growth Plan and opening up a portion of the Greenbelt would each have the second largest benefit of $\$ 21$ billion in savings. Altogether, reducing regulatory and development burdens 
province-wide, as outlined in tables 10.2 and 10.3, would reduce the cost of single-detached dwellings by a total of $\$ 123$ billion. These figures represent the value that existing homeowners receive through higher home prices because of restrictions on new development. These large values show why governments are often hesitant to loosen restrictions on new development.

\section{The Relative Cost of Supply Restrictions versus Demand Stimulus}

What are the relative effects of supply restrictions compared to possible demand drivers of higher house prices? The average cost of a single-detached dwelling in municipalities in the GTA in 2016 was $\$ 828,000$ (figure 10.3). The policies of municipal governments in the GTA and the province have resulted in prices that are, on average across the region, $\$ 25,000$ higher because of restrictions on land use and $\$ 62,000$ higher because of above-average development costs and delays. One of the main questions for policymakers is how much home prices have been inflated through higher demand due to the low interest rates that have been in place since 2008 (Head and Lloyd-Ellis 2016). Policymakers will want to know what the likely effect of an increase in interest rates will be on the broader economy, with housing costs being the main channel (see Kronick 2017a). Some cities have also seen a large influx of households, driving up prices.

I add interest rates to the analysis used above to determine, in an admittedly rudimentary way, the effect the chartered bank conventional five-year mortgage rate had on house prices in any given year. Because I am using house prices reported on an annual basis, I take the annual average of the interest rate on the typical five-year conventional mortgage that the Bank of Canada reports on a monthly basis. Other writers, such as Glaeser, Gottlieb, and Gyourko (2010), investigate the effect of interest rates on U.S. house prices using a longer time series going back to 1975 , with more variation in 
interest rates than in the period we have. They find that interest rates explain one-fifth of the rise in U.S. home prices from 1996 to 2006.

I find, as expected, that house prices go down as mortgage rates increase, reflecting lower demand for housing due to more expensive mortgages (figure 10.3). I take the estimated relationship between house prices and mortgage rates and ask what the hypothetical price response in the Ontario market would be if mortgage rates increased by 50 percent. With interest rates averaging 4.7 percentage points in 2016, I examine the effect on house prices if mortgage rates increased by 2.3 percentage points, reaching 7 percentage points - a level last seen before the 2008 recession. The finding: such a rate increase would decrease the value of single-detached dwellings by $\$ 31,000$. However, this figure is likely an underestimate of the effect of interest rates. Because there has not been much variation in interest rates over the study period, it is difficult to pin down the effect of year-over-year interest rate changes that are larger than those that have occurred in recent years.

If cities across the GTA had no household growth instead of their annual average growth in the number of households over the last three years, which we calculate to smooth out large one-year growth spurts, house prices would be $\$ 13,000$ lower. This rough estimate - as there are other factors that will drive costs of homes as well - shows the relative importance of supply restrictions on the price of housing. Even a dramatic increase in interest rates and a fall in household growth would not have the same effect as reducing supply barriers (such as cutting development charges or zoning requirements) in lowering the cost of single-detached housing.

\section{How Cities Can Cut the High Cost of Housing}

Municipalities and provinces across Canada can take steps to reduce the economic cost of restrictions on new building. Among other steps flowing from the analysis above and discussed in more detail elsewhere (Clayton 2015), the three obvious changes are to reduce 
Figure 10.3: Effect on GTA Housing Prices from Supply Restrictions, Interest Rates, and Household Growth Rate

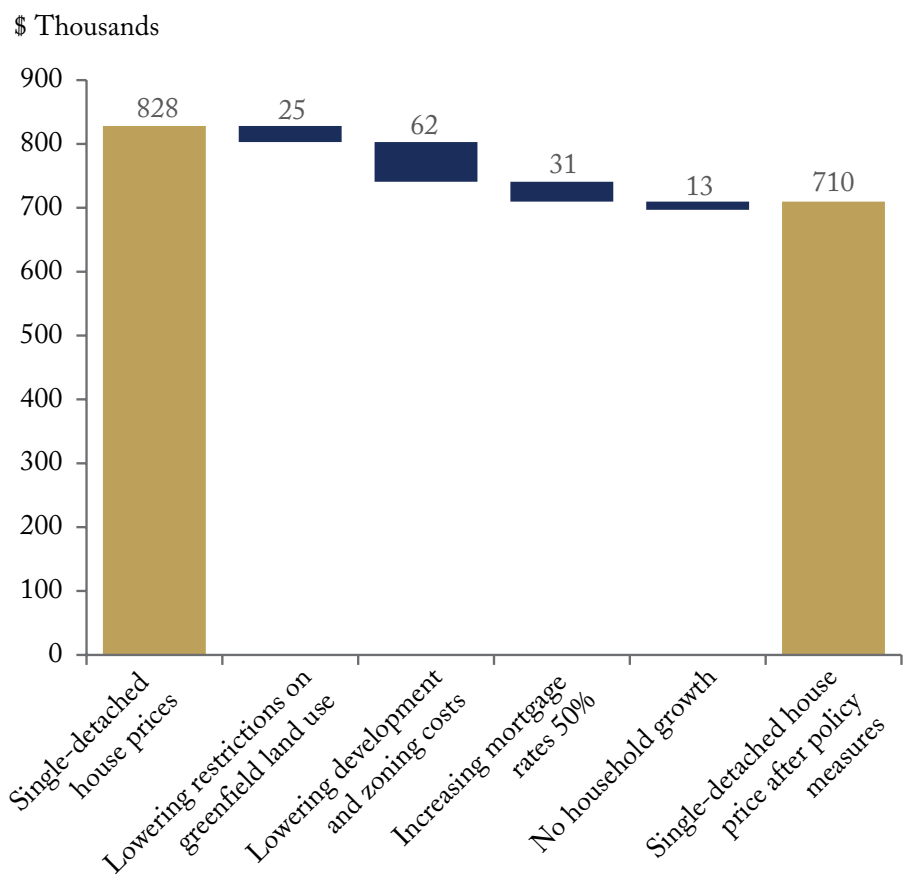

Source: Calculations from Dachis and Thivierge (2018) and from Ontario Ministry of Municipal Affairs, RPS, Statistics Canada, and Bank of Canada data. GTA municipalities are those in Toronto and in Halton, Peel, York, and Durham regions.

zoning barriers, remove water and wastewater services from development charges (replacing them with a utility-based fee-for-use model), and ease restrictions on greenfield housing development.

\section{Reduce Zoning and Approval Barriers}

Why does the City of Toronto have the highest zoning review rate, requiring zoning reviews of over 80 percent of houses? Although Toronto amalgamated its six constituent municipalities in 1998, it has not yet fully updated the specific zoning rules that lay out the 
allowable height or density on any given piece of land, nor has it updated some zoning bylaws since the 1950s (the bylaws that had not been changed between the 1950s and 1998) (Tuckey 2017). These outdated zoning regulations mean that most new developments are contrary to the existing zoning bylaws, necessitating a lengthy and costly zoning review. Outdated zoning bylaws would make infill development, similar to single-detached housing, difficult to approve in neighbourhoods that have zoning permitting only very low-density housing. Ontario municipalities, Toronto in particular, should update their zoning bylaws to match local regulations with official plans that lay out municipal-wide objectives. In addition to reducing the length of the zoning review process, municipalities can adopt better approval practices, such as allowing electronic permit applications (rather than requiring paper filing) or using external professionals as well as municipal staff to review building permits (Duong and Amborski 2017).

\section{Reduce Upfront Costs on Developers}

Two kinds of upfront costs that cities impose on developers get passed onto homebuyers. Because these costs are pervasive, I'll be discussing them in more detail below (see chapter 11).

First, the cities of Toronto and Vancouver frequently require additional payments from developers in exchange for a site-specific variance from zoning bylaws (Moore 2018). These additional payments, known as Section 37 payments for the relevant part of the Planning Act in Ontario, or "Community Amenity Contributions" in Vancouver, increase uncertainty for developers and increase the cost of housing.

Second, developers pay development charges to compensate municipalities for the cost of building municipal infrastructure that services homes and commercial properties in a newly developed area (Dachis 2018b). Development fees are politically popular because 
they are portrayed as money paid by profitable developers rather than by homeowners, who have little appetite for increased property taxes. But these kinds of upfront costs increase home prices, for both existing homeowners and new homebuyers, meaning that more people are unable to afford homes in Canada's thriving cities (see chapter 9). The better way to ensure that taxpayers don't subsidize new urban development is by making the users of new infrastructure pay for the full cost of new developments over the time they use the service, rather than all at once. Such a move has other benefits too (see chapter 11).

\section{Review Restrictions on Greenfield Housing Development}

Developers usually build greenfield single-detached residential development on what was previously agricultural land. However, developers in GTA municipalities are facing a shortage of land available for new housing development (Clayton 2015). This result is consistent with the data in table 10.3, showing that municipalities with a high share of land zoned for agriculture in cities subject to the Growth Plan have higher housing costs. It's not just the Greenbelt, however, that drives up housing prices: the most tractable policy issue is developing land between existing urban growth boundaries and the Greenbelt.

The densification and intensification measures in the provincial Growth Plan - those setting numerical targets on the number of jobs and residents on new developed land, and requirements for much of the new development to happen within existing boundaries - likely explain the lack of development on land within the Greenbelt. These policies limit the availability of land for residential development, increasing the cost of homes (as shown in table 10.3). Further, these targets may not be appropriate across all cities subject to the Growth Plan because they have different intensities of existing residential developments, and many will face challenges in meeting these targets (Malone Given Parsons 2017). Density targets in areas 
with access to nearby transit may be sensible but may not be cost effective across the entire area currently subject to the Growth Plan. As such, they should be relaxed in cases where they are not sensible.

Finally, the province should review the costs, as shown in table 10.3, as well as the benefits of preserving or expanding the Greenbelt around the GTA. A U.K. study (Cheshire and Sheppard 2002) found that the value people place on the visual amenity of inaccessible Greenbelt space, such as agriculture, was much less than their value of accessible Greenbelt park space (in 2015 Canadian dollars, $\$ 3,300$ versus $\$ 8,000$ ). In addition, U.K. Greenbelt policies were regressive in that high-income households were able to enjoy Greenbelt space, but low-income urban residents, often without vehicles, did not have access to the Greenbelt but paid the cost of the Greenbelt through higher home and rent prices. More recent studies have shown that U.K. Greenbelts have no amenity value beyond the owners of homes within the Greenbelt area, and that even those who live near the Greenbelt put no value on living close by (Gibbons, Mourato, and Resende 2011). Because the costs on new housing of expanding the Greenbelt appear to be small, as shown in table 10.3, the net result of a cost-benefit analysis may show that the greatest net benefit comes from expanding the Greenbelt while allowing more development on land closer to the existing urban boundary. That goal can be accomplished by loosening the intensity and density target of the Growth Plan.

\section{How to Make Homes More Affordable in Canada's Cities}

Restrictions and extra costs on building new housing - such as zoning regulations, delays on permit approvals, development charges, and limits on greenfield housing development - are dramatically increasing the price of housing, by over $\$ 100,000$ in some Ontario municipalities. More generally, barriers to development on housing, which is the overall gap between the cost of building new housing 
and the market price, are also substantial in a number of areas in British Columbia and across the GTA.

What can cities and provinces do to cut down on the cost of housing? Municipal governments and provinces can reduce regulatory and development cost burdens on housing by replacing development charges with user fees, easing zoning restrictions, and allowing for greater flexibility in developing new housing in places with little land zoned for new housing. New single-detached housing need not be rampant, sprawling development. The housing debate in the Toronto area - and in other cities with similar policies - has often focused on the Greenbelt. However, the Greenbelt is not the core problem driving up house prices. Relaxing other constraints on development, such as lowering onerous development charges or relaxing strict growth plans that limit the use of agricultural land between urban areas and the Greenbelt, are the easiest ways to lower the cost of single-family housing. 


\section{Appendix}

This appendix summarizes the technical material regarding the data and empirical method used in Dachis and Thivierge (2018) that is reproduced in this chapter.

\section{Data}

For our analysis of the effect of specific housing regulations on the price of housing, we start with data from the Ontario Financial Information Return (FIR). We use information from Schedule 80D from 2014 through 2016 (Schedule 92 in previous years) to collect information on land use, the share of building-permit applications that requires additional zoning approval, and permit approval times. We use Schedule 62 to collect information on development charges. Because many municipalities have multiple development charges that apply in different parts of the municipality and for different services, we create a single total development-charge amount based on the average reported total figure from the sum of the lower- and upper-tier total development charges, as each level of government sets its own charges. We assume that municipalities that do not report a development charge do not levy one.

We use Geographical Information System software to estimate the share of each Ontario municipality's land that is within the Greenbelt, based on maps from the Ministry of Natural Resources, as well as municipal government (Census Subdivision) maps from Statistics Canada. In all, 97 Ontario municipalities have some of their land in the Greenbelt. We assume that other municipalities have no land subject to the Greenbelt. We also find a large degree of reporting error among cities in regard to the share of each municipality's land that is zoned for agriculture. We take the most common entry for the total hectares of land zoned for agriculture in the municipality and use that amount in place of either missing values or when the amount of agricultural land deviates by more 
than 20 percent from the most commonly reported number for the municipality. A similar year-over-year change in land development is unlikely to occur in reality, and if it does, it is thus most likely to be a reporting error.

We merge the data from the FIR to Statistics Canada data at the CMA or Census Agglomeration (CA) level for employment income, which we control for in all regressions. Nearly half the municipalities fall into the broad "non-CMA/CA" category, covering 1.1 million people as of 2016. There are 42 other CMAs, ranging in size from the Toronto CMA as the largest, with a population of 6.4 million, to those with just over 10,000 people - such as Hawkesbury, Elliot Lake, or Ingersoll. Some CAs and CMAs do not have employment income data for all years. To estimate income for those affected municipalities, we assume that income changed in that CA or CMA at the same rate as the rest of the province relative to the first year in which we have income data for the CMA. As of the publication date of Dachis and Thivierge (2018), Statistics Canada has also not released income data for 2016 at the CMA level. We use provincial-wide employment income from Cansim Table 384-0002 and assume that the year-over-year growth in income is the same across the province, and we apply that growth rate to each CMA's 2015 income level. We take the log of each year's employment income and include that as a control in all our regressions.

In our final step, we merge our FIR and Statistics Canada data with single-detached house price data available at the individual municipality level from Real Property Solutions (RPS), which provides price data for nearly every municipality with a population over a few thousand people. We have sale price information both for single-detached housing and the aggregate price of housing in each municipality for every year since 2005 . This information allows us to test the effect of supply barriers, using the average annual price for each year from 2005 through 2016. 


\section{Empirical Approach}

In our regression analysis, our dependent variable is the natural logarithm of the price of single-detached housing. In all regressions, we control for the income in the CMA, whether the municipality is rural or urban (according to RPS), as well as for CMA/CA fixed effects. Following Hilber and Vermeulen (2016), our regression equation in its simplest form is as follows:

$\log \left(P_{i \mathrm{cml}}\right)=B 1,_{i \mathrm{~cm}} x_{i \mathrm{cmt} t}+B 2,_{m} e_{m t}+B 3 r_{t}+u_{t}$

$P_{\text {icmt }}$ is the price of single family housing (which we take in log form) in year $t$, in municipality $i$, which is a subdivision of Census Division $c$, which is located in a Census Metropolitan Area/Agglomeration $m$. All our regressions have controls for each year $t$ and Census Metropolitan Area/Agglomeration $m$. Our policy variables $x$ are the average overall periods $\underline{t}$ over every year in which the municipality $i$ reports data.

Because it can take many years for a policy-induced supply constraint to affect house prices, we take the average over all years for each of the policy variables we use as controls in our regression (see table 10.A1 for information on the years and number of municipalities that report data for each variable). Our approach follows that of Hilber and Vermeulen (2016), who take the average jurisdiction-specific rejection rates and development rates of their sample of English cities. Taking the average of policy variables allows us to eliminate some of the endogeneity of the effect that higher prices may have on the desire to introduce stricter land-use control. Such averaging means we cannot include controls for each municipality $i$ to reflect municipality-specific fixed effects.

Some policy variables, such as development charges, are partially set by the upper-tier government, which is the same definition as the Census Division $c$. We include controls of employment income $e$ in each Census Metropolitan Area/Agglomeration $m$ in 
each year $t$. We also control for the Canada-wide interest rate $r$ in each year $t$. All time series variables are stationarity in differences. These same variables are cointegrated and, as such, we run the regression in log-levels. We also add a variable that measures the distance of each municipality's geographical centre to downtown Toronto.

In the first two regressions, we exclude the Census Division controls. In the third, fourth, and fifth regressions, we also include controls for the 48 Census Divisions in which each municipality is located. However, as many of our control variables, such as the application of the Growth Plan, vary only at the Census Division level, in the second, fourth, and fifth regressions we use an interaction variable of the interest rate in a given year with each municipality's development charge. For example, development charges are largely determined by upper-tier governments, which are also the boundaries of Census Divisions. Specifically, the average effect of development charges on house prices is inferred from the interacted coefficient and the estimated interest rate coefficient, which is itself derived from the interacted effect of municipal income and interest rates. In the above regression equation, that would represent $r_{t}^{*} x_{i c m t}$ for the development-charge variable. The results in the main text of chapter 10 reflect development charges on house prices, given the interest rates that were in effect in 2016.

We also include the annual rate of growth of the number of households in each municipality. Not all municipalities report household numbers every year in the FIR. In those cases, we calculate an annualized growth rate using household numbers that are two or more years apart and assume that the household growth was the same for all years with missing values. 
Table 10.A1: Detailed Regression Results Without Income Interaction

\begin{tabular}{|c|c|c|c|c|c|}
\hline \multirow{2}{*}{ Dependent Variable } & \multicolumn{4}{|c|}{$\begin{array}{c}\text { Price of Single-detached } \\
\text { Dwelling }(\log )\end{array}$} & \multirow{2}{*}{$\begin{array}{l}\text { Aggregate } \\
\text { Home Price } \\
(\log ) \\
\text { (5) }\end{array}$} \\
\hline & (1) & (2) & (3) & $\begin{array}{l}\text { (4) preferred } \\
\text { specification }\end{array}$ & \\
\hline Municipality is rural & $\begin{array}{c}-0.0952^{* *} \\
(-2.73)\end{array}$ & $\begin{array}{c}-0.0952^{* *} \\
(-2.74)\end{array}$ & $\begin{array}{l}0.122^{*} \\
(1.88)\end{array}$ & $\begin{array}{l}0.122^{*} \\
(1.88)\end{array}$ & $\begin{array}{l}0.106^{*} \\
(1.81)\end{array}$ \\
\hline $\begin{array}{l}\text { Log of employment } \\
\text { income in CMA- } \\
\text { annual }\end{array}$ & $\begin{array}{l}-0.229 \\
(-0.32)\end{array}$ & $\begin{array}{l}1.214^{* *} \\
(2.33)\end{array}$ & $\begin{array}{l}1.234^{* *} \\
(2.18)\end{array}$ & $\begin{array}{l}1.196^{* *} \\
(2.26)\end{array}$ & $\begin{array}{l}1.330^{* *} \\
(2.37)\end{array}$ \\
\hline $\begin{array}{l}\text { Annual household } \\
\text { growth rate }\end{array}$ & $\begin{array}{l}0.103^{* *} \\
(4.29)\end{array}$ & $\begin{array}{c}0.102^{* *} \\
(4.33)\end{array}$ & $\begin{array}{c}0.0602^{* *} \\
(3.28)\end{array}$ & $\begin{array}{c}0.0585^{* *} \\
(3.20)\end{array}$ & $\begin{array}{c}0.0532^{* *} \\
(2.88)\end{array}$ \\
\hline $\begin{array}{l}\text { Average days to approve } \\
\text { single-family home }\end{array}$ & $\begin{array}{l}0.0000108 \\
(0.01)\end{array}$ & $\begin{array}{l}0.0000102 \\
(0.01)\end{array}$ & $\begin{array}{c}0.000663 \\
(0.77)\end{array}$ & $\begin{array}{c}0.000665 \\
(0.77)\end{array}$ & $\begin{array}{l}0.000249 \\
(0.26)\end{array}$ \\
\hline $\begin{array}{l}\text { Average share of house } \\
\text { permit applications } \\
\text { requiring rezoning }\end{array}$ & $\begin{array}{c}0.162^{* *} \\
(5.60)\end{array}$ & $\begin{array}{c}0.162^{* *} \\
(5.60)\end{array}$ & $\begin{array}{c}0.0534 \\
(1.52)\end{array}$ & $\begin{array}{l}0.0534 \\
(1.52)\end{array}$ & $\begin{array}{r}0.0465 \\
(1.20)\end{array}$ \\
\hline $\begin{array}{l}\text { Share of municipality's } \\
\text { land zoned agriculture }\end{array}$ & $\begin{array}{c}0.00401 \\
(0.08)\end{array}$ & $\begin{array}{c}0.00455 \\
(0.09)\end{array}$ & $\begin{array}{c}0.0628 \\
(0.91)\end{array}$ & $\begin{array}{r}0.0635 \\
(0.91)\end{array}$ & $\begin{array}{l}0.0608 \\
(0.78)\end{array}$ \\
\hline $\begin{array}{l}\text { Maximum combined } \\
\text { upper- and lower-tier } \\
\text { DC for } 2012-2016 \\
\text { (thousand - log) }\end{array}$ & $\begin{array}{l}0.0640^{* * *} \\
(6.69)\end{array}$ & $\begin{array}{c}0.136^{* *} \\
(3.93)\end{array}$ & $\begin{array}{c}-0.00407 \\
(-0.25)\end{array}$ & $\begin{array}{c}0.0681^{* *} \\
(2.12)\end{array}$ & $\begin{array}{c}0.0469 \\
(1.53)\end{array}$ \\
\hline $\begin{array}{l}\text { Share of land area of city } \\
\text { in Greenbelt }\end{array}$ & $\begin{array}{l}0.194^{* *} \\
(2.18)\end{array}$ & $\begin{array}{l}0.194^{* *} \\
(2.17)\end{array}$ & $\begin{array}{l}0.273 \\
(1.29)\end{array}$ & $\begin{array}{l}0.273 \\
(1.29)\end{array}$ & $\begin{array}{l}0.290 \\
(1.45)\end{array}$ \\
\hline $\begin{array}{l}\text { Indicator if city is subject } \\
\text { to Growth Plan }\end{array}$ & $\begin{array}{l}-0.0918 \\
(-1.54)\end{array}$ & $\begin{array}{c}-0.0919 \\
(-1.54)\end{array}$ & & & \\
\hline $\begin{array}{l}\text { City subject to Growth } \\
\text { Plan times share of land } \\
\text { zoned agricultural }\end{array}$ & $\begin{array}{l}0.160 \\
(1.58)\end{array}$ & $\begin{array}{l}0.160 \\
(1.58)\end{array}$ & $\begin{array}{l}0.128^{*} \\
(2.02)\end{array}$ & $\begin{array}{l}0.127^{*} \\
(2.00)\end{array}$ & $\begin{array}{l}0.182^{* * *} \\
(2.33)\end{array}$ \\
\hline \multicolumn{6}{|c|}{$\begin{array}{l}\text { Note: t-statistic in brackets using cluster robust standard errors at the Census Metropolitan Area } \\
\text { level. Statistical significance: }{ }^{*} p<0.10 \text {, }{ }^{* *} p<0.05 \text {. Source: Calculations from Dachis and Thivierge } \\
\text { (2018) and from Ontario Ministry of Municipal Affairs, RPS, and Statistics Canada data. All } \\
\text { models include year fixed effects and CMA and CA indicators. }\end{array}$} \\
\hline
\end{tabular}




\begin{tabular}{|c|c|c|c|c|c|}
\hline \multirow{2}{*}{ Dependent Variable } & \multicolumn{4}{|c|}{$\begin{array}{c}\text { Price of Single-detached } \\
\text { Dwelling }(\log )\end{array}$} & \multirow{2}{*}{$\begin{array}{l}\text { Aggregate } \\
\text { Home Price } \\
(\log ) \\
\text { (5) }\end{array}$} \\
\hline & (1) & (2) & (3) & $\begin{array}{l}\text { (4) preferred } \\
\text { specification }\end{array}$ & \\
\hline $\begin{array}{l}\text { Distance of centre } \\
\text { of municipality to } \\
\text { downtown Toronto } \\
(\mathrm{km})\end{array}$ & $\begin{array}{c}-0.000634^{* *} \\
(-26.07)\end{array}$ & $\begin{array}{c}-0.000633^{* *} \\
(-26.23)\end{array}$ & $\begin{array}{c}-0.00253^{* *} \\
(-3.04)\end{array}$ & $\begin{array}{c}-0.00253^{* *} \\
(-3.04)\end{array}$ & $\begin{array}{c}-0.00253^{* *} \\
(-4.12)\end{array}$ \\
\hline $\begin{array}{l}\text { Interest rate times } \\
\text { annual average } \\
\text { combined upper- and } \\
\text { lower-tier DC for } \\
2012-16\end{array}$ & & $\begin{array}{l}-0.0127^{* *} \\
(-2.04)\end{array}$ & & $\begin{array}{c}-0.0127^{* *} \\
(-2.03)\end{array}$ & $\begin{array}{r}-0.0084 \\
(-1.44)\end{array}$ \\
\hline $\begin{array}{l}\text { Log of income times } \\
\text { interest rate }\end{array}$ & & $\begin{array}{l}-0.168^{* *} \\
(-3.11)\end{array}$ & $\begin{array}{l}-0.215^{* *} \\
(-3.37)\end{array}$ & $\begin{array}{c}-0.167^{* *} \\
(-3.11)\end{array}$ & $\begin{array}{l}-0.207^{* *} \\
(-3.45)\end{array}$ \\
\hline Other controls & \multicolumn{5}{|c|}{ Census Division: (3) - (5), year, CMA/CA } \\
\hline Observations & \multicolumn{5}{|c|}{2974} \\
\hline \multicolumn{6}{|c|}{$\begin{array}{l}\text { Note: t-statistic in brackets using cluster robust standard errors at the Census Metropolitan Area } \\
\text { level. Statistical significance: }{ }^{*} p<0.10,{ }^{* *} p<0.05 \text {. Source: Calculations from Dachis and Thivierge } \\
\text { (2018) and from Ontario Ministry of Municipal Affairs, RPS, and Statistics Canada data. All } \\
\text { models include year fixed effects and CMA and CA indicators. }\end{array}$} \\
\hline
\end{tabular}

We conduct our analysis of the Growth Plan by using an interaction variable with the share of land that is zoned as agricultural. The interpretation of the results is to add the coefficients together depending on the effect of agricultural land on its own (a minor effect), plus whether the municipality is subject to the Growth Plan and an additional effect of agricultural land share if the municipality is subject to the Growth Plan. When we present estimates that include an interaction variable, we also include the effect on its own of the variable that is not changing, such as income. 
In our regressions, we include the effect on house prices of the annual average of the interest rate on the typical five-year conventional mortgage that the Bank of Canada reports. The effect of the interest rate will likely have a different effect on house prices in a municipality with high income compared to a municipality with low income. Further, the interest rate is the same across Ontario in any given year - that makes it impossible to distinguish the effect of interest rates from any inherent factors affecting prices in a given year. To solve these problems, we create an interaction variable that is the product of the log of employment income variable with the interest rate. That solves the problem of a lack of variation in the province by creating variation in interest rates across the province in any given year through the channel in which it will likely affect house prices: income. In our above equation, that would be represented as $r_{t^{*}} e_{m t}$. The results from the fourth regression are what we use in the empirical analysis in chapter 10. In our final regression, we used the same regression equation and instead used the aggregate price of houses in each municipality. The results are largely the same as in our preferred specification.

To create our predicted price from reduced restrictions, we use our preferred specification in column 4 from table 10.A1 and use the coefficients to estimate the reduction in price that would occur from the change in the policy variable in each municipality if, instead, the municipality was at the provincial average for that variable. 


\section{Chapter 11}

\section{How to Lower Costs for Homebuyers and Renters}

Housing affordability is an important issue in Canadian cities (see chapters 9 and 10), just as finding money to pay for much-needed infrastructure is too. Municipalities often frame development charges as a painless way of paying for new infrastructure without increasing taxes. Developers paid $\$ 2.4$ billion directly to Ontario municipalities in 2016. ${ }^{40}$ Cities across Canada are also increasing their development charges. As a recent example, the City of Toronto enacted a plan in mid-2018 to increase development charges for various kinds of homes. Development charges for a single-detached house are set to increase from less than $\$ 20,000$ in 2012 to over $\$ 80,000$ in 2020 (Toronto 2018d).

As housing prices spike, development charges are on the rise as well. In this chapter, I look at how much and why municipalities rely on homebuyers to fund new infrastructure. Many Canadian municipalities are overly reliant on homebuyers as a way to pay for

40 Based on the author's calculations from Ontario Ministry of Municipal Affairs and Housing, Financial Information Return Schedule 61. This chapter draws heavily on the text from Dachis (2018b). 
new infrastructure. For infrastructure supported by user fees, such as water or wastewater services, municipalities should eliminate upfront costs on homebuyers and instead charge end users the full cost.

The economic evidence from Canada and the United States shows that development charges increase the price of housing. Every 10 percent increase in development charges on a new single-detached dwelling results in homes increasing in price by 0.45 percent (see chapter 10). Cutting development charges by a magnitude similar to removing water and wastewater charges would have the largest effect in York and Peel regions in Ontario, reducing single-detached home prices by around $\$ 52-\$ 78,000$. House prices would decrease by the extent to which households place a discounted value on the future costs of higher water fees, as opposed to paying upfront for these costs with development charges.

Explicit development charges are only part of the problem. Toronto, Vancouver, and other cities frequently require additional payments from developers in exchange for a site-specific variance from zoning bylaws (Moore 2018). The so-called Section 37 benefits in Ontario and the Community Amenity Contributions in British Columbia have become shadow development charges that cause major problems to developers because of the uncertainty surrounding their costs. It's time that these two provinces changed the acts that govern these kinds of payments and make them less common and more transparent.

Lowering costs on new home construction will reduce costs for both homeowners and renters. Costs are one part of a two-part approach to helping more low-income Canadians find the kind of housing they need. Low incomes are the root of the other half of the housing affordability problem for those most in need. Reorienting the way governments support renters by putting money in their hands rather than by mandating inclusionary zoning or rent controls - is a 
better way to improve housing for Canadians struggling the most to obtain it.

\section{Development Charges}

Charges on homebuilders, often called impact fees or, more commonly in Canada, development charges, are one of the single largest capital financing tools for municipalities. In Alberta these charges are called offsite levies, and in British Columbia, development cost charges.

\section{The Economics and Politics of Development Charges}

Developers pay development charges to compensate municipalities for the cost of building municipal infrastructure that services homes and commercial properties in a newly developed area. In other words, growth pays for itself. Development charges apply only to projects that will require the city to provide more services. For example, the expansion of a house, which does not increase the number of housing units, would in most instances not incur one. Municipalities can also charge development charges in specific areas and for specific kinds of development.

In theory, an ideal development charge would reflect the incremental (marginal) cost of building new infrastructure (Blais 2010): the end users who benefit from a service would be the ones who pay for it. Some municipalities differentiate among development charges based on whether development is in an entirely new area or within the existing urban growth boundary. Such differentiation is a move toward matching beneficiaries with costs. Development charges also often differ by parts of the municipality. However, these types of upfront financing create an incentive for households to make heavy use of the infrastructure, such as roads or water, and that attitude leads to congestion or the overuse of water. 
The empirical evidence from elsewhere shows that new homebuyers pay almost all the development fees (see also chapter 10). Recent studies of similar fees in U.S. municipalities have found that upfront charges on homes are added to home prices to varying degrees, ranging from 83 percent to over 500 percent of the costs of development charges. Most studies show at least 100 percent of development charges are embedded in house prices. ${ }^{41}$ This rise in home prices reflects, to some extent, real value added to the house by the new amenities - the municipality is charging fees so it can build or improve infrastructure that can be used by the residents. However, the price increase from widely used amenities - such as parks - often accrues to all homeowners in the city, not just newcomers who are paying development fees.

The upfront cost of all development charges presents a potential equity concern: new homebuyers have to pay upfront for all development costs while existing homeowners get a free ride. To the extent that development charges are embedded in resale prices, in competitive markets the price increase will spread to all houses whether or not development charges were paid on a property resulting in a pure windfall for previous generations of homebuyers already living in a municipality with development charges.

In supporting development charges, municipal voters are often endorsing policies that will increase the resale values of their homes at minimum cost to themselves (Fischel 2001). Particularly when local governments collect little future revenues from new growth, development charges may increase the political support for building new homes - development that normally faces incumbent homeowner opposition. Homeowners often oppose new development because they resist competition in the resale market which would lower the investment value of existing homes (Hilber and

41 See, for example, Evans-Cowley et al. 2009; Mathur 2007; Mathur, Waddell, and Blanco 2004; and Ihlanfeldt and Shaughnessy 2004. 
Robert-Nicoud 2013). For example, if a municipal government does not collect revenues to finance infrastructure, such as by increasing property taxes on new homes, incumbent residents will know that new housing developments will increase their own taxes, so they will oppose new development. Development charges may end up strengthening political support for increasing housing supply by making new amenities and/or lower taxes for incumbent residents conditional on the city approving new housing (Cheshire 2017; Burge and Ihlanfeldt 2006).

\section{What Municipalities Collect from Builders}

Provincial legislation lays out the authority for municipalities to set development charges, but municipalities enact specific bylaws to guide their application. Development charges can be as high as nearly $\$ 80,000$ in some Greater Toronto Area (GTA) municipalities for a single-detached house in a new development area (figure 11.1a). The average development charge in the GTA has steadily increased from $\$ 45,000$ in 2012 to $\$ 60,000$ in 2016 . In 2018 , the City of Toronto enacted a bylaw that will see development charges increase to morethan $\$ 80,000$ for a single-detached house by 2020 .

Major cities elsewhere in Canada have much lower development charges, ranging from just over $\$ 20,000$ in Calgary to between $\$ 30,000$ and $\$ 35,000$ in cities such as Hamilton (Ontario), Ottawa, and Surrey (B.C.) (figure 11.1b). Quebec has not granted municipalities the right to levy development charges. The City of Winnipeg introduced a development charge on construction projects that began after May 1, 2017 (Winnipeg 2018). ${ }^{42}$

Edmonton has set development charges for non-water infrastructure, but developers enter into service agreements with the city for the cost of developing new water infrastructure. Across Canada,

42 The City of Winnipeg set the initial fee at $\$ 57.47$ per square metre. For the average Winnipeg single-detached home of 125 square metres, that amounts to about $\$ 7,200$ in development charges. 


\section{Figure 11.1a: Development Charges on New Single-Detached Housing in Select GTA Area Cities, 2012-16}

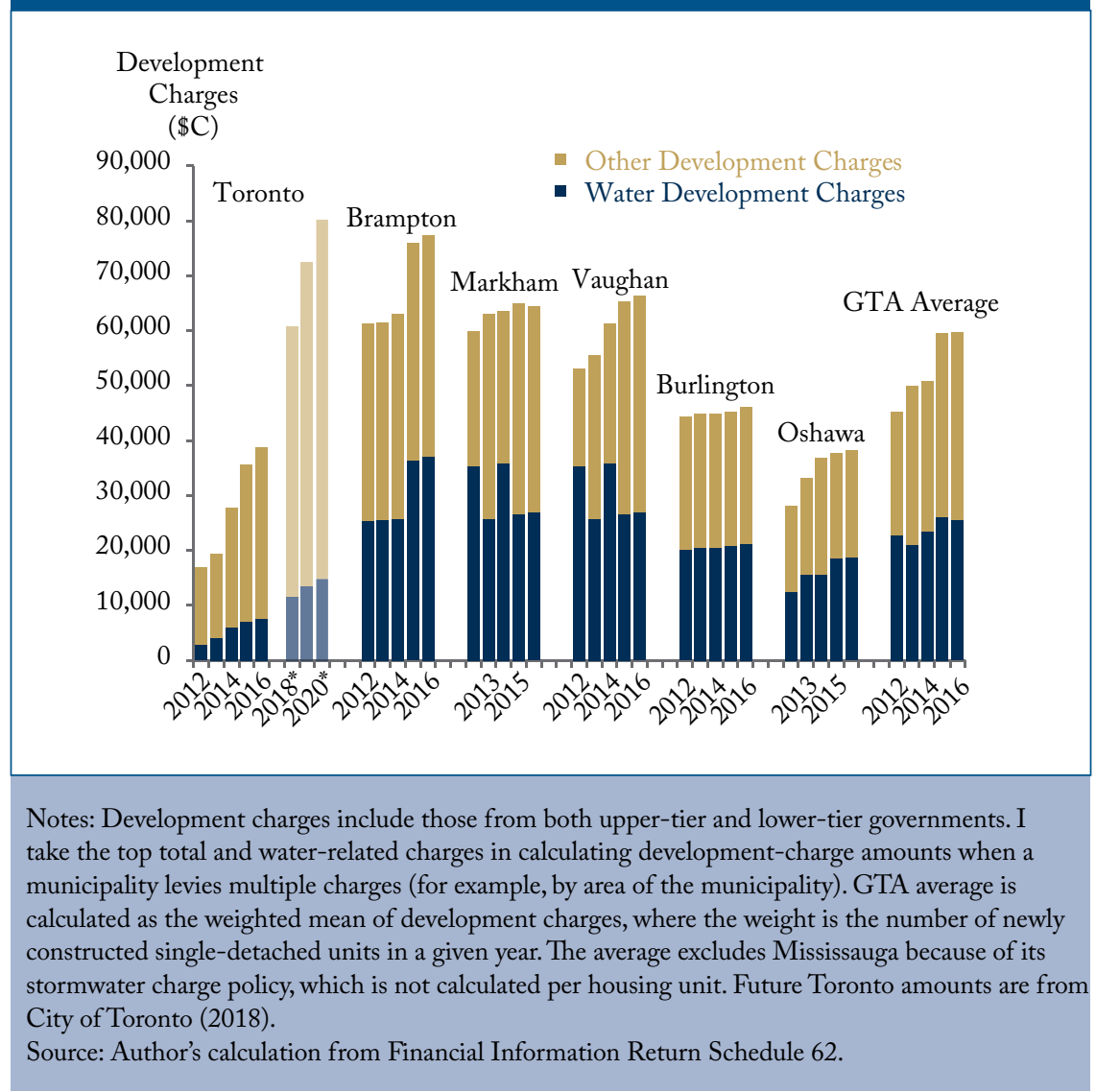

the largest single component of development charges are for water, wastewater, and sewer infrastructure (combined here as water DCs). Water development charges range from as little as 20 percent of total development charges in cities such as Toronto or Ottawa, which have largely developed their water infrastructure, to 50 percent or more of the total development charges in spreading suburban municipalities. 


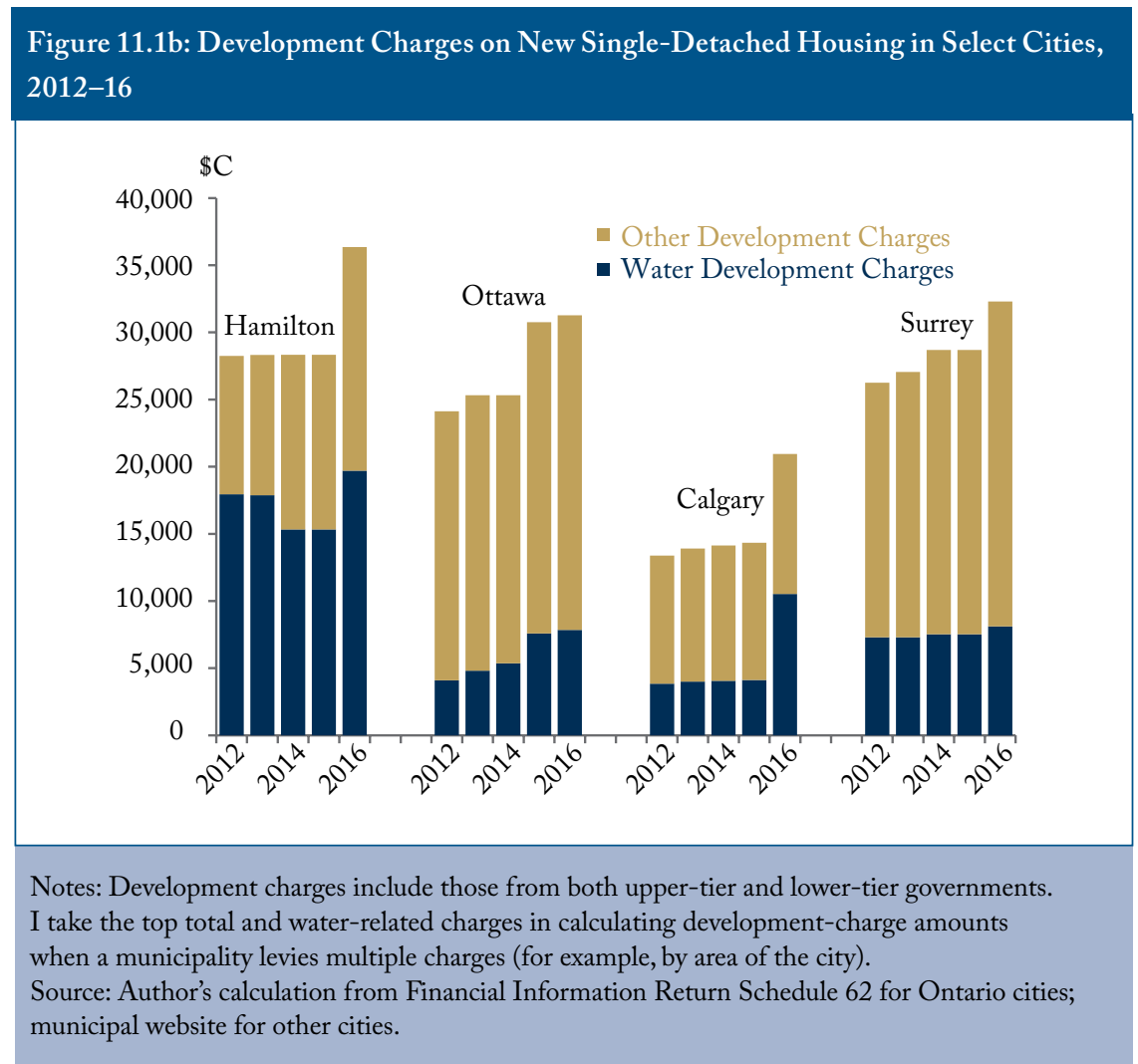

\section{What Municipalities Build}

Municipalities collect development charges before construction and place the funds into dedicated reserves. Municipalities then spend the reserves over time, as the city gradually expands the services for which it collected fees. The needed infrastructure is not always developed on a timely basis. From 2010 to 2016, Ontario municipalities collected $\$ 11.1$ billion in total development charges, $\$ 4.3$ billion of which was dedicated for water infrastructure (figure 11.2). However, just over half of what municipalities have collected in water development charges, or $\$ 2.4$ billion, has gone to capital expenditure 

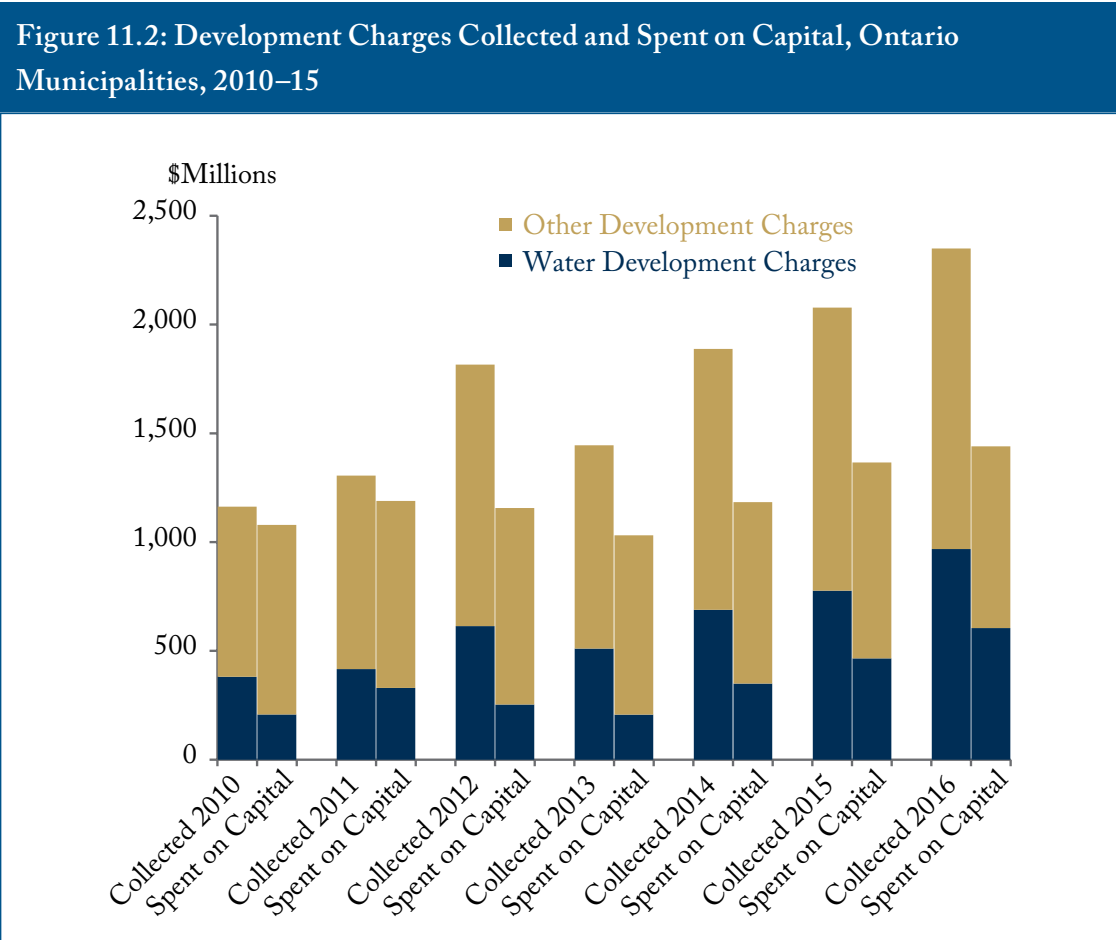

Notes: "Water" includes water, wastewater, and sewers.

Source: Author's calculation from Ontario Financial Information Return Schedule 61.

on water, resulting in $\$ 1.9$ billion in unspent development charges meant for water infrastructure. In contrast, municipalities have spent about 80 percent of the development charges they have collected for other types of assets on related capital investments.

In addition to monetary development charges, municipalities sometimes ask developers to build capital assets themselves and, after completion, to hand them over to municipalities as part of a subdivision development agreement. Municipalities refer to these as "in kind" or "donated assets." Because these donated assets are not cash items, municipal budgets, which operate on a cash budgeting 
system, ignore the value of these assets granted to them by developers. Donated assets appear only in municipal end-of-year financial statements and in province-wide statistics that are collected on an accrual accounting system (see chapter 2). The key takeaway is that municipal cash-based budgets are understating the cost they are imposing on municipal taxpayers (which includes new homebuyers) by ignoring these kinds of costs.

Alberta breaks out donated capital assets in the water and wastewater sector as a share of the total capital additions that municipalities made to their services. More than one-third of the value of wastewater capital additions in 2015 in Alberta was through donated assets ( $\$ 384$ million), as were 20 percent (\$95 million) of water investments. However, I do not include such donated assets in the analysis below because other provinces don't provide a similar breakdown. I will also discuss a similar system in Ontario called Section 37 payments, or contributions in kind, and a similar policy called Community Amenity Contributions in British Columbia.

\section{Water and Wastewater Services in Alberta and Ontario}

Water and wastewater are among the largest operating costs. In addition, they represent the largest capital expenditure of Canadian cities (30 percent of Ontario municipal capital investment, and 26 percent among Alberta municipalities in 2015). ${ }^{43}$

\section{The Cost of Water and Wastewater Services}

Ontario and Alberta provide comprehensive data regarding their water and wastewater utilities. For Ontario, the total 2015 operating

43 In this section, I separate drinking water and wastewater services. I combine water treatment, collection, and transmission in a single "water" category and include all sewer services and wastewater collection, treatment, conveyance, and disposal in a single "wastewater" category. Municipalities are increasingly providing storm sewers on a separate basis, but it is difficult to identify the extent to which they provide them on a fully separate basis from wastewater. 
cost, which includes the share of municipal-wide administrative costs attributable to water and wastewater utilities and the annual amortization of existing capital assets, was $\$ 2.2$ billion for water services and $\$ 2.6$ billion for wastewater (table 11.1). Alberta spent $\$ 600$ million in water services and nearly $\$ 700$ million on wastewater. For both provinces, the total annual cost per household of these services ranges from $\$ 346$ to $\$ 360$ for water services and from $\$ 370$ to $\$ 438$ for wastewater. In addition, Ontario municipalities spent $\$ 1.6$ billion on wastewater infrastructure in 2015 and $\$ 1.8$ billion on water. Alberta spent $\$ 965$ million and $\$ 506$ million, respectively.

Municipalities are collecting user fees approximately equal to the annual operating cost of water and wastewater utilities. As for their capital expenditures on water and wastewater, municipalities have funded them through two main sources: development charges, as discussed above, and capital grants from other levels of government. Between 2009 and 2015, Ontario municipalities received about $\$ 200$ million in operating grants dedicated to water or wastewater from the province and the federal government, and nearly $\$ 2$ billion in dedicated federal and provincial capital grants.

\section{Reforming Development Charges and Water and Wasterwater Services}

Municipalities can reduce the cost of new housing by replacing development charges with full-cost user pricing. They can also reduce the cost of water services by achieving greater economies of scale. Municipalities and provinces can better meet the goals of optimal pricing and lower costs through economies of scale. To do so, they should create standalone utility corporations to operate regionally under the watchful eye of independent regulators.

\section{Building Bigger and More Efficient Water and Wastewater Systems}

The average size of utility providers or organizations is small in both provinces, with the average utility having fewer than 25,000 


\begin{tabular}{|c|c|c|c|c|}
\hline & \multicolumn{2}{|c|}{ Water } & \multicolumn{2}{|c|}{ Wastewater } \\
\hline & Ontario & Alberta & Ontario & Alberta \\
\hline $\begin{array}{l}\text { Annual Operating } \\
\text { Cost }\end{array}$ & $\$ 2.2$ billion & $\$ 599$ million & $\$ 2.6$ billion & \$689 million \\
\hline $\begin{array}{l}\text { Annual Operating } \\
\text { Cost per Household }\end{array}$ & $\$ 346$ & $\$ 360$ & $\$ 370$ & $\$ 438$ \\
\hline $\begin{array}{l}\text { Total Capital } \\
\text { Additions }\end{array}$ & $\$ 1.8$ billion & $\$ 506$ million & $\$ 1.6$ billion & \$965 million \\
\hline Total User Fees & $\$ 2.3$ billion & $\$ 667$ million & $\$ 2.4$ billion & $\$ 729$ million \\
\hline $\begin{array}{l}\text { Households Served by } \\
\text { Average Utility }\end{array}$ & 20,648 & 6,067 & 23,148 & 6,607 \\
\hline \multicolumn{5}{|c|}{$\begin{array}{l}\text { Note: Edmonton's water utility, but not wastewater, is provided by Epcor, which is not included in } \\
\text { municipal statistics. } \\
\text { Source: Author's calculations from Ontario Financial Information Return and Alberta Municipal } \\
\text { Affairs Municipal Financial \& Statistical Data. }\end{array}$} \\
\hline
\end{tabular}

customers in Ontario and fewer than 10,000 in Alberta. ${ }^{44}$ Water utilities require substantial investments in water-treatment facilities, and the network economies of a single pipe system make these systems a natural monopoly in which the larger the scale of the service, the more efficient the operation. Just as there are scale economies, to a point, in the Ontario electricity sector (see Fyfe, Garner, and Vegh 2013), there are clear economies of scale in the water and wastewater sector around the world, such as in England (Bottasso and Conti 2009), Portugal (Marques and De Witte 2011), and Australia (Worthington and Higgs 2014), to name just a few examples.

Forced utility consolidation, as was done through top-down municipal amalgamation (Bish 2001) or previous proposed forced

44 This measure of the "average" utility size sums the total number of customers in the province and divides by the total number of utilities. The median utility size, the utility in which half the utilities are larger or smaller, is considerably smaller in each province. 
mergers in the Ontario electricity sector (Fyfe, Garner, and Vegh 2013), are unlikely to reduce costs. Instead, a cooperative regional model in which individual municipalities elect to take part in a special-purpose body that consolidates the activities of a group of utilities is most likely to lead to savings (Spicer and Found 2016). One example of creating an overarching, region-wide service provider is Aquaterra in Grand Prairie, Alberta, which has combined the water services of both the City of Grand Prairie and the broader regional government and a nearby smaller town.

Another option is for provinces to allow municipal governments to create special-purpose government bodies. These bodies are common in parts of the United States and are known as Municipal Utility Districts. They are able to issue bonds to finance local infrastructure investments that future residents of new areas pay for, such as through property taxes. These districts are most appropriate to replace non-user-fee-based services included in development charges.

\section{Getting Pricing Right}

Many municipalities have started to cover historical capital costs and other operating expenses of water and wastewater rather than recoup them through user fees (table 11.1). Without the need for capital renewal, that would be an ideal pricing model: those who benefit from an asset are those who pay for it. However, municipalities are investing heavily in new assets. Only if municipalities charge the full cost of both annual operations and amortization will consumers pay the full cost of water assets. When customers pay the full cost of using an asset on a life-cycle basis, they are implicitly making the choice of consuming the right amount of water every time they turn on the taps or flush their toilet. Charging less than the full cost results in households overconsuming water.

However, full-cost pricing is incompatible with the current system of financing capital infrastructure upfront with development 
charges. New homebuyers would be paying twice for the upfront capital investment through development charges and an annual amortization expense embedded in user fees. Similarly, capital grants from other levels of government discourage municipalities from charging the full cost of every litre of water. Higher levels of government should not be giving grants for water and wastewater infrastructure to municipalities that can charge users the full cost of water. Part of the reason that municipalities seek upfront revenue in place of long-term finances is the manner in which municipalities budget (see chapter 2).

Upfront cash from development charges and capital grants looks appealing when municipalities use cash budgets, and the imperative is to match cash inflows with cash outflows, not necessarily the flow of the benefits from the infrastructure that future generations will receive. But as I have discussed, that allure, based on cash budgeting, is deceiving. Provinces should change their existing municipal act provisions on budget presentation to enable municipalities to present budgets on an accrual basis.

Municipalities should eliminate development charges for water and wastewater and instead levy full-cost user fees that cover the full cost of amortized capital (as argued by Clayton 2014). This pricing model has been used for decades by private and municipally owned utilities in the natural gas and electricity market, without any reliance on upfront fees. If municipalities moved to such a system for new developments, housing affordability would improve. If households have the same time value of money as the interest rate paid to finance the upfront investment, the cost to consumers in the long run will be the same. If interest rates are lower than the value that households place on the future value of money today, the net costs to households will be lower in the long run.

Quebec, which does not use development charges, collects water-related property taxes on a per-building-lot or 
per-foot-of-frontage calculation. This system leads to higher property taxation, but only in the new developments that would otherwise be subject to high water-related development charges in other provinces. It also ensures that infrastructure is modest in its design and cost and that it is financed over its useful life, or the term of the financing, to defray the initial capital costs. Rather than adopt such long-term financing via the property tax base, which does not encourage water conservation, municipalities elsewhere in Canada can achieve the same outcome of long-term financing with per-use pricing.

\section{Enabling Public or Private Utilities to Provide Water and Wastewater} Services

A major impediment to reform of water and wastewater services is that in many municipalities they are line-item operations within the city - they are indistinguishable from other city services. Some cities, such as Windsor (EnWin), Edmonton (Epcor), or Innisfil (InnServices) in Simcoe County, Ontario, have moved their water services into separate corporations. These municipalities have also taken steps toward integration with local electricity companies to take advantage of economies of scope in which different businesses take advantage of similar types of billing or administrative services. Moving to a utility model can have numerous benefits: first, these services would be less likely to receive property tax subsidies; second, separate utilities would be better positioned for future mergers or cross-border agreements; and, third, utilities could practise modern accrual accounting in their budgeting, unlike the overall municipality, which can enable full-cost recovery pricing over the life-cycle of the assets (Fenn and Kitchen 2016).

For example, Epcor, which is owned by the City of Edmonton, provides services for other cities, as does Corix, which is owned by bcIMC, an institutional investment manager for pension plans. Moving to a standalone utility model can also create opportunities for more private investment in water and wastewater services 
(see chapter 8). Institutional investors, especially Canadian pension funds, hold major investments in water and wastewater infrastructure all around the world. Ontario can also remove a major impediment to private infrastructure investment in water and wastewater by removing the operating mandate from the Ontario Clean Water Agency, a provincial Crown agency that operates water utilities for many towns across Ontario. Brubaker (2011) argues that this agency has an unfair competitive advantage over new entrants.

Rather than have municipalities take on debt or push homebuyers into greater debt through development charges, institutional investors would be interested in building, owning, and operating water and wastewater facilities. For example, Epcor provides services for other cities, as does Corix. Alternatively, if municipalities do not want to sell their ownership of water or wastewater infrastructure, they can instead rely on public-private partnerships (P3s) to use private infrastructure finance, which results in lower risk to taxpayers, in place of government financing. Infrastructure Ontario provides these services across the province for municipalities, but it has not, as of mid-2018, ventured into financing water or wastewater assets. The Ontario government can expand the mandate of Infrastructure Ontario to include water and wastewater services, potentially replacing the use of development charges by municipalities for upfront financing.

\section{Reforming Regulation}

Before governments actively pursue private water and wastewater infrastructure ownership, they should create the appropriate regulatory environment. Creating an arm's-length regulatory agency for major water and wastewater infrastructure can have numerous benefits, independent of whether the asset is privately or publicly owned. Without such an independent body, governments have an inherent conflict of interest when they hold the powers of both operating and regulating infrastructure in areas such as safety or price setting. 
Weaker regulatory standards simply make the operations easier to manage. Creating an independent infrastructure regulator - for example, the United Kingdom set up Ofwat for its water sector - can both address this conflict and monitor any potential private investors.

Canadian provinces should establish new regulatory bodies or expand the scope of existing regulatory bodies to cover both private and municipal water services. For example, Ontario's electricity and natural gas price regulator, the Ontario Energy Board, could be recast as the Ontario Utilities Board and have responsibility for the water sector. Similarly, the Alberta Utility Commission could be granted authority over the public water sector, as it currently does for the private water sector. These regulators could ensure that municipal governments and private operators set rates and submit financial plans that meet the public interest of long-term sustainability. ${ }^{45}$

\section{Density Bonus Charges}

Development charges are only part of the upfront costs put onto developers. In many Ontario cities, for example, developers who are building a property that is taller or larger than the area zoning allows have, by the "Section 37 agreements," to provide a payment to the city or a benefit to the community - such as public art, a daycare centre, or low-income housing. Developers also pay planning fees, dedicate parkland, or make payments in lieu of the market value of dedicated parkland. City planners negotiate with developers over benefits the local councillor lays out. This windfall gives politicians an opportunity to finance ribbon-cutting projects in their ward rather than less exciting infrastructure projects that may be equally needed.

Vancouver has a similar zoning problem to Toronto's. Outdated zoning restricts the ability of developers to build more homes in existing neighbourhoods. Municipalities negotiate with

45 As Fenn and Kitchen (2016) note, this suggestion was championed (unsuccessfully) by MPP David Caplan's Private Member's Bills 13/10 and $237 / 10$. 
developers to provide "Community Amenity Contributions" when a development proposal exceeds zoning bylaws (Davidoff 2016, 2017).

\section{The Cost of Density Bonuses}

Relatively little data are available on how much Canadian cities have collected from housing developers. The first study of these benefits relied on trawling through the minutes of City of Toronto council meetings to count how many, what type, and where Section 37 benefits occurred (Moore 2013). One study found that between 1998 and 2015 , the City of Toronto collected just over $\$ 400$ million in these benefits (Friendly 2017). The money that goes to city coffers because of them and other extra development costs are only a fraction of the actual cost. Section 37 agreements often compel developers to devote space nearby or within their buildings to non-cash negotiated benefits - leading to less revenue for developers and higher costs for buyers or tenants.

Section 37 agreements are borne unequally: some developers pay large amounts, while others pay nothing. The reason these payments are uncertain is that municipalities do not have the legal authority to make them explicit - doing so would turn them into a kind of tax. However, the Ontario Municipal Act and the City of Toronto Act do not permit cities to levy such a tax. Indeed, the City of Toronto has noted that laying out an explicit formula for Section 37 benefits would not survive a legal challenge (Friendly 2017). These payments are therefore decided in the backrooms of municipal governments, and their very uncertainty increases the cost of housing.

Municipalities may also have an incentive to keep zoning bylaws out of date - necessitating more project reviews - because updating them would take away future Section 37 payments. Density bonus regimes act as a tax on increased density (Moore 2018). If developers are going to be penalized for building more, they won't want to build more density. Their incentives may be to build homes 
either within the currently restrictive zoning limits or seek a major deviation from zoning rules to build a very tall building. Only such a building would be worth the hassle of going through months or years of negotiations. In the end result, Section 37 may mean fewer homes in the "missing middle" density level - the kind that is in short supply because of regulatory burdens (discussed below).

\section{How to Reform Density Bonuses}

Density bonusing plays a role in preventing NIMBYism - the powerful "not in my backyard" anti-development syndrome. New developments bring increased congestion, lost views, and other costs to existing residents. Section 37 benefits may bridge that divide by providing local residents with a tangible benefit that persuades them to allow greater density in their community. The alternative to removing density bonusing might be having no development at all.

One simple solution is to allow cities to codify explicitly what they expect in Section 37 benefits from developers. That at least would level the playing field between developers and municipal governments. Smaller developers would have greater cost certainty and more incentive to build projects that are only marginally above existing zoning regulations.

While amenities increase the value of housing, requiring developers to finance them results in homebuilders paying upfront for these kinds of services. A better solution is to finance municipal amenities over the life of the service. For community services, that means putting more of the total cost onto property taxes and paying for services that benefit the overall community as they operate.

The way to square this circle is land-value capture (see chapter 4). A land-value capture tax would allow local residents to benefit from new amenities paid for, in part, by new construction. Land values increase in a neighbourhood near a new transit line, for example, because developers look at properties in the area and think 
they can profitably put more people, or people willing to pay a premium, on the existing plots. Land-value capture is a way to get many of the best parts of density bonusing, while not having the downsides of backroom deals and a mismatch of those who pay with those who benefit.

\section{Cutting the Cost of Rental Housing}

We've focused so far on how to reduce the cost of housing for the typical single-family house that so many Canadians aspire to buy or already own. As of 2016, about two-thirds of homes in Canada are owned by their occupants. Yet, for many others, these kinds of homes will be out of reach, no matter how much governments reduce their costs. As the price of housing increases overall, dealing with affordability problems for those with low incomes has become increasingly important. Making housing more affordable is a two-part problem that requires both cutting the cost of housing and putting money in the hands of people who need the housing.

\section{Inclusionary Zoning}

Cities around the world, particularly in some parts of the United States, require developers to devote a portion of their developments to social housing, or to make a payment in lieu of that housing. This requirement is called inclusionary zoning - and it is coming to Canada.

Inclusionary zoning would put more of the burden of building low-income housing on private developers instead of on taxpayers. Ontario passed legislation in 2018 that will grant explicit powers to cities in the province to have bylaws that require developers to set aside a share of units in their development for low-income housing.

Inclusionary zoning is a way to provide low-cost housing at the expense of increasing housing costs for others. It is akin to a tax on new development. When governments tax something, prices go 
up, less of it gets made, or both. Developers will pay the initial cost of building the low-income units, but the evidence from inclusionary zoning elsewhere is that it is homebuyers who ultimately pay. A comprehensive study of California inclusionary zoning programs shows that they were successful in increasing the number of multi-residential units, but that new house prices in cities with inclusionary zoning increased by 2 to 3 percent overall relative to cities without such programs. However, the programs marginally decreased prices at the bottom half of the market by 1 percent, while increasing prices in the top half by 5 percent compared to cities without inclusionary zoning (Bento et al. 2009).

Inclusionary zoning is essentially a redistributive solution to a social problem, and it puts the burden for social policy largely on new homebuyers. However, it would be far more sensible for the cost of supporting housing for those with low incomes - either through construction support or supports directly to families - to be borne through redistributive taxes, such as income taxes and consumption taxes (see below). In addition, linking any kind of requirement for social housing with increased density, as in Section 37 benefits, is a blunt tool for capturing the windfall increase in land value. It would be far better to institute a revised property tax that captures some of the increase in land value (see chapter 4).

\section{Building More Market-Driven Housing}

People who need affordable housing probably can't wait for that provided by inclusionary zoning. In any case, it will provide only a very small percentage of housing completions over the coming decade. For context, the total number of annual housing completions in the entire Toronto area has been around 30,000-40,000 per year between 2003 and 2013 (Evergreen 2015). Even if all housing projects required that 10 percent of units must be affordable, it would take many decades for there to be enough units ready for the more 


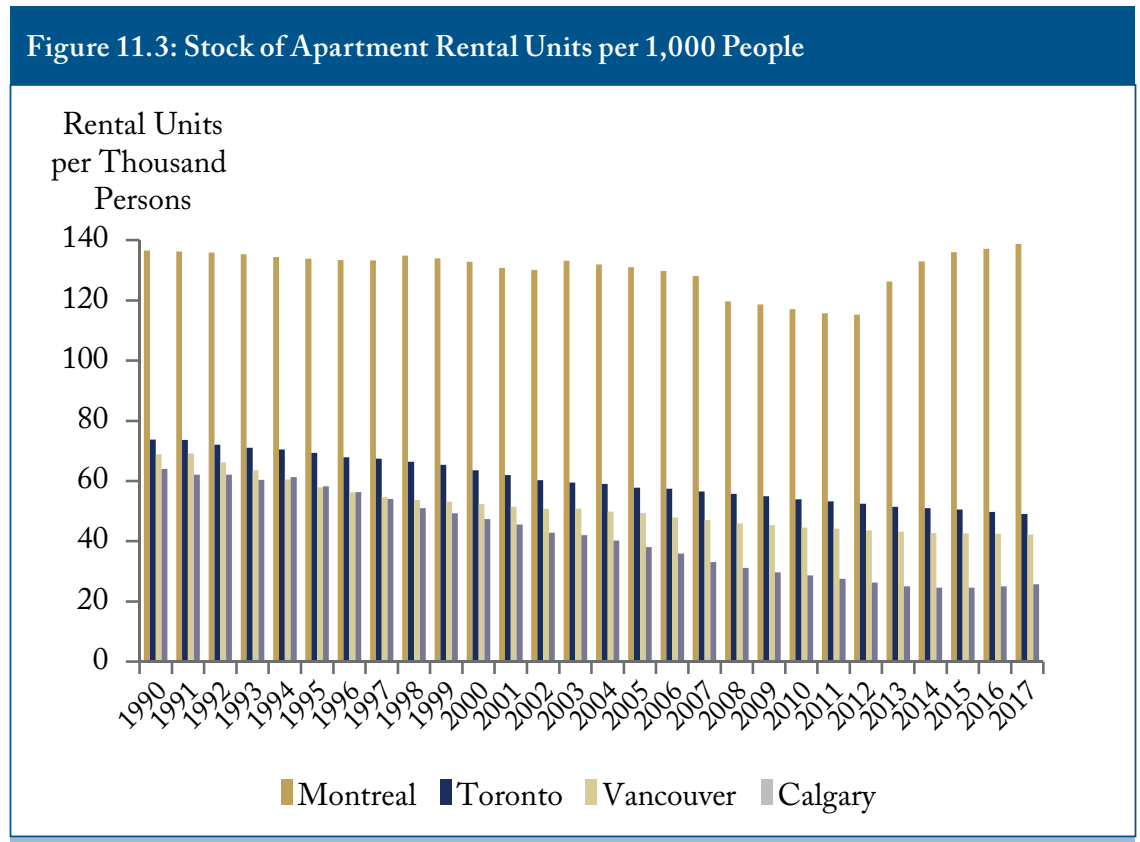

Source: Based on data presented by Wilkins (2017a).

than 100,000 households on the waiting list for social housing in the Toronto area alone.

At the same time, the available options in the rental market have been plummeting in much of Canada for the last 25 years. The Vancouver and Toronto areas saw similar population growth after 1990. Yet the rental stock in both cities barely budged or even fell, partly because more people bought their own homes rather than continue to rent. In particular, the rental stock for low-rent places has fallen. By 2016, the stock of rental units per 1,000 people had fallen from about 70 units to between 40 and 50 (figure 11.3, from Wilkins 2017a).

The situation was even worse in Calgary. As of 2016, there were barely more than 20 rental units available for every 1,000 
residents. Calgary was one of the few cities left, until 2018, that did not allow secondary suites - basement apartments or other units rented at affordable prices. Despite having one of the more flexible markets for the price of owner-occupied housing (having avoided big increases in purchase prices compared to Vancouver or Toronto), Calgary's market was inhospitable for renters looking at the low end of the market (see chapter 9). A lone parent on social assistance in Calgary would be paying two-thirds of total income on a barebones rental apartment - one in which the rent is in the bottom fifth of rental costs in the city (Wilkins 2017b).

Montreal has seen a very different story. Rental properties have experienced considerable growth in the last 25 years, the last five in particular. The ratio of rental properties per 1,000 people in Montreal is many times that of the other major Canadian cities. There's also a wider range of rental options within an affordable range for many households on social assistance. Taking that same single-parent family on social assistance and moving it from Calgary to Montreal will cut their rental costs to one-third of total income (Wilkins 2017b).

What makes Montreal unique in keeping housing costs down? Unlike other big cities, Montreal has a large share of medium-density housing - dwellings in the range between urban skyscrapers and suburban tract housing. ${ }^{46}$ Much of the zoning in Montreal, unlike that in Toronto and Vancouver, enables this kind of "missing middle" housing within the existing city. Historically, Montreal had this medium density in central areas before the introduction of zoning, which in turn tended to reflect the pre-existing density. This zoning allowed developers to develop medium-density housing easily. The cost per square foot of constructing housing often increases as height increases (see chapter 9), but in Montreal the

46 See http://urbankchoze.blogspot.com/2014/04/les-escaliers-de-montreal-vs-towers-of.html 
amount of low-cost medium-density construction kept the price of housing down.

\section{Ending Rent Control}

Calgary took steps in March 2018 to alleviate the shortage of rental housing by allowing homeowners to rent out secondary suites. Eleven months previously, on April 20, 2017, the Ontario government expanded rent control to cover all rental units in the province, not just those built before 1991 - a move that will likely further reduce the supply of rental housing. That means that all rental units in the province are now limited by a maximum allowed increase. If rental property owners have faced large capital expenses or increases in other costs, they can apply for rent increases above these guidelines. Doing so, however, comes at a large regulatory cost, and the application may not be successful.

Rent control is an appealing short-term political move. Renters have the assurance that their rent will increase slowly over the long term. Solid empirical evidence has shown, however, that rent control does not lower the cost of housing in the long run (Kronick 2017b). The likely result of rent control is that housing developers will not build rental housing, knowing they face a cap on potential returns but not on investment risk. The result will be fewer units available, leading to housing shortages. As we saw in Calgary, the people most likely to be hurt by a lack of rental options are those with a low income. Rent control also leads to people staying in rental housing even when it may no longer fit their needs.

Ontario landlords are limited to increasing rents by a provincially set maximum, regardless of the expenses they face (unless their appeal is successful). Quebec, which has greater experience than other provinces with rental properties, has a more flexible model of rent control. ${ }^{47}$ It provides a comprehensive calculator that allows

47 https://www.rdl.gouv.qc.ca 
landlords to pass on costs out of their control - such as needed maintenance - without needing to go through the process of a special provincial rent-increase approval.

In addition to this kind of flexibility, provinces should loosen rent controls to allow for annual increases, until the controls are eventually repealed. Another compromise is to limit the length of time that rent controls apply after tenants begin their lease (Hall 2017), progressively reducing the length of time rent controls apply until repeal.

\section{Creating a No-Strings-Attached Housing Transfer}

Many provinces provide financial transfers to households to supplement rents, though they take a variety of forms (see Pasolli et al. 2016 for a summary). In some provinces, renters have to apply for transfers; in others, they are universal. Some transfers are delivered through the tax system; others are standalone subsidies. The design of many current transfers leaves much to be desired. Rent subsidies like those in Ontario, for instance, have been linked with other social assistance benefits, creating a "welfare wall" that discourages people from trying to get off social assistance (Laurin 2018).

Given all the costs and problems with social housing, and the unintended side-effects of many of the current rent transfers, several economists and social-housing advocates have come together with a recommendation. Along with other existing supports, they say, a household benefit based on income is one of the best ways to improve housing affordability (Zon and Nelles 2017; Pomeroy et al. 2008).

This no-strings-attached transfer to households could be modelled on the recently introduced federal Canada Housing Benefit, which will start in 2020. The details of its design are still to be determined, but should it be administered through the tax system, a person in housing need would not have to sit on a waiting list for social housing or apply through a separate program to get housing support. Provinces could simply convert their current transfers into 
income-tested transfers that would be available to anyone in housing need - based largely on income but also on factors such as number of children and housing costs in the place where they live. Provinces could also convert their tax credit programs for property taxes - such as those for low-income families and for seniors - into universal transfers.

Cities could do the same with property tax cancellation programs they have for senior citizens. Why should property owners get a subsidy from the city while renters of similar age and income next door do not? Both renters and owners face recurrent expenses for having a place to live. These kinds of programs should be neutral for someone who owns or rents. Moving to a housing supplement, along the lines of the Canada Housing Benefit, for municipal and provincial housing supports would be a more equitable way to help low-income families with their housing needs. It will also improve the functioning of the housing market. Seniors would not have a financial incentive to stay in a house they had been considering selling simply because they didn't want to lose their property tax supports (see chapter 4).

This proposal to put money into the hands of those in need should be paired with reductions in restrictions on other aspects of housing supply. Increases in demand without the ability for landlords to build new housing would result in more money chasing the same number of rental units. A more generous subsidy system for low-income renters, paired with reduced costs on builders, is a recipe to lower the cost of housing for middle-class and low-income Canadians alike.

\section{Cutting Water Waste and Housing Costs at the Same Time}

Canadian municipalities are imposing expensive charges on housing developers which are worsening the affordability of housing across the country. Municipalities should replace the largest single 
component of these charges - those that finance water and wastewater construction - with fees based on the actual use of these services. Density bonusing regimes should also be reviewed and replaced with formal land-value capture across the country, particularly in cities such as Toronto or Vancouver.

Municipalities in Ontario, for example, have not been using all the development charges they have collected for water and wastewater investments. A large amount has gone toward reserve funds, which means that the people paying development charges have not received the benefits they paid for. Today's taxpayers are fully paying for infrastructure that will benefit people in the future.

The largest single component of these charges - ranging from 20 percent of total charges in built-out cities such as Toronto and Ottawa to 50 percent in some parts of the Greater Toronto Area - is for water and wastewater construction. It would be better to charge for these services based on actual end use, as is common with electricity and natural gas, instead of through up-front fees. Removing development charges for water and wastewater and charging consumers only on end use would better reflect the actual use of water, leading to less overconsumption of water as well.

Provinces should empower a province-wide safety and price regulator to oversee all water operators in the province. That system will allow municipalities to contract out, or have private investment in their water and particularly their wastewater services. Municipalities can also create region-wide, standalone utilities to take advantage of the economies of scale that are available in the sector.

Cutting costs on construction can help renters and owners alike. Montreal's zoning rules have enabled a large share of development to occur at low cost. Cutting housing costs is one part of a two-pronged approach to improve housing options for low-income Canadians. If we can reorient supports for social housing by putting 
money directly into the hands of people regardless of whether they rent or own, along the lines of the Canada Housing Benefit, we'll be off to a good start, and we can then begin to tackle the other half of this problem: low incomes themselves. 



\section{Epilogue The New Canadian City}

It's morning again, a few years from now, in one of Canada's cities. And what a few years it has been. Our heroine from the first chapter made her move downtown once the land transfer taxes declined. It's election day too, and she has a slate of council candidates to choose from. All the serious candidates are running as part of a distinct party platform, using clear fiscal numbers to present their ideas for spending plans. Everyone works from the same facts.

She's closer to work now and has many options for getting there. Today she'll drive in the car-share vehicle parked right outside her house. They're everywhere now, and she's even sold her own car. She has an important meeting today, so she'll drive in on the high-occupancy toll lane. That way she knows exactly how long the drive will take. She also knows she'll be able to find parking: once the city created a new parking app that changes prices by the minute, a spot is always available.

Our heroine doesn't follow that route every day. Tomorrow is not as busy, so she'll drive but use one of the non-toll lanes. Yesterday she took a bus downtown: it also uses the high-occupancy toll lane, 
so it doesn't waste time sitting in traffic. The bus is operated by the municipal government for the community she used to live in. Now it operates seamlessly across municipal borders under a service agreement with the regional transit authority.

On the drive into town, she hears discussion on the radio about a possible new subway line into her neighbourhood. The numbers are pretty clear: we don't need it now because the bus operating on the high-occupancy toll lane is providing good service. Both the toll lane and the rest of the general-purpose lanes are moving faster. But, in another part of town, a pension fund thinks it can make the numbers work. The city has cash on hand from selling its local electricity company. It is more self-sufficient now, relying less on grants than in the past. The mayor is announcing that the city will chip in to the pension fund's plan so it can lower fares and expand the reach of the proposed line. Electricity distribution costs haven't increased either. There's talk of prices falling as the new electricity company is integrating services across the region.

Our heroine's business is thriving too. Business property taxes are lower, and people can easily get downtown to her shop now. House prices have been declining slowly over the last few years, giving customers more discretionary money. Lower prices also mean that more people can afford to buy a home. They're paying for municipal services as they use them - water in particular. Residents near new transit lines pay a little extra in their property taxes. In both cases, the upfront costs on homeowners are falling, and people pay for the benefits from new infrastructure when they use it.

Life is better now than it was a few years ago. Our heroine can hardly believe that a few key changes in how the city operates have made daily life so much easier.

Canadians do live good lives when public services are provided efficiently. Canada is one of the most prosperous countries in 
the world because of its excellent schools. It is one of the healthiest countries in the world because of our public healthcare system. The same can be true for municipal policy. Life for millions of people in Canada's urban areas can go from good to great with a few simple changes. Not every urban area faces the same problems, but the shared problems can all benefit from some of the changes we discuss in this book. All Canadian cities can improve how they present their financial information. They can reduce their tax burden on businesses and cut traffic congestion by putting a price on roads. They can build more infrastructure by encouraging private dollars to invest in it. They can properly price water so as not to waste it, and at the same time they can cut the cost of housing. It's up to all of us to make these suggestions a reality in our cities. 


\section{References}

Alberta. 2015. “Capital Plan. Fiscal Plan 2015-18.”

Althaus, Catherine, and Lindsay M. Tedds. 2016. "User Fees in Canada: A Municipal Design and Implementation Guide." Canadian Tax Foundation, 212.

Altus Group. 2017. “Canadian Cost Guide: 2017.”

Amaral, Miguel, Stephane Saussier, and Anne Yvrande-Billon. 2006. "Does Competition for the Field Improve Cost Efficiency? Evidence from the London Bus Tendering Model.” Center for Network Industries and Infrastructure. CNI-Working Paper No. 2006-14.

Andrews, Dan, Aida Caldera Sánchez, and Åsa Johansson. 2011. "Housing Markets and Structural Policies in OECD Countries.” OECD Economics Department Working Paper 836. Paris: Organisation for Economic Co-operation and Development. January.

Auditor General of Ontario. 2014. 2014 Annual Report of the Office of the Auditor General of Ontario. Chapter 3, Section 3.05.

Bel, Germa, and Anton Costas. 2006. "Do Public Sector Reforms Get Rusty? Local Privatization in Spain.” Journal of Policy Reform 1 (9): 1-24.

Bel, Germa, and Xavier Fageda. 2008. "Privatization and Competition in the Delivery of Local Services: An Empirical Examination of the Dual Market Hypothesis." Xarxa de Referència en Economia Aplicada working paper 2008-4. Barcelona, Spain.

Bel, Germa, and Mildred Warner. 2008. "Does Privatization of Solid Waste and Water Services Reduce Costs? A Review of Empirical Studies." Resources, Conservation and Recycling 52 (12): 1337-48.

Bento, Antonio, Scott Lowe, Gerrit-Jan Knaap, and Arnab Chakraborty. 2009. "Housing Market Effects of Inclusionary Zoning." Cityscape 11 (2): 7-26.

Bérard, Guillaume, and Alain Trannoy. 2017. "The Impact of a Rise in the Real Estate Transfer Taxes on the French Housing Market." Marseille, France: AMSE Working Paper 1732, AixMarseille School of Economics.

Besley, Timothy, Neil Meads, and Paolo Surico. 2014. "The Incidence of Transaction Taxes: Evidence from a Stamp Duty Holiday.” Journal of Public Economics 119: 61-70.

Best, Michael Carlos, and Henrik Jacobsen Kleven. 2017. "Housing Market Responses to Transaction Taxes: Evidence from Notches and Stimulus in the UK." Review of Economic Studies 85(1): 157-93.

Bird, Richard, and Enid Slack, eds. 2015. Is Your City Healthy? Measuring Urban Fiscal Health. Toronto: Institute on Municipal Finance and Governance.

——. 2017. Financing Infrastructure: Who Should Pay? Montreal \& Kingston: McGill-Queen's University Press.

Bird, Richard, Enid Slack, and Almos Tassonyi. 2012. A Tale of Two Taxes: Property Tax Reform in Ontario. Cambridge, MA: Lincoln Institute of Land Policy. 
Bish, Robert. 2001. Local Government Amalgamations: Discredited Nineteenth-Century Ideals Alive in the Twenty-First. Commentary 150. Toronto: C.D. Howe Institute.

Blais, Pamela. 2010. Perverse Subsidies: Hidden Subsidies, Wonky Policy and Urban Sprawl. Vancouver: UBC Press.

Bottasso, Anna, and Maurizio Conti. 2009. "Scale Economies, Technology and Technical Change in the Water Industry: Evidence from the English Water Only Sector." Regional Science and Urban Economics 30: 138-47.

Boyer, Marcel, Eric Gravel, and Sandy Mokbel. 2013. The Valuation of Public Projects: Risks, Cost of Financing and Cost of Capital. Commentary 288. Toronto: C.D. Howe Institute. September.

Brubaker, Elizabeth. 2011. A Bridge Over Troubled Waters: Alternative Financing and Delivery of Water and Wastewater Services. Commentary 330. Toronto: C.D. Howe Institute. May.

Bula, Frances. 2018. "Forewarnings - and maybe farewell warnings - on the future of urban fairways." Globe and Mail. March 30.

Burge, Gregory, and Keith Ihlanfeldt. 2006. "Impact Fees and Single-Family Home Construction.” Journal of Urban Economics 60 (2): 284.

Büttner, Thiess. 2017. "Welfare Cost of the Real Estate Transfer Tax.” Beiträge zur Jahrestagung des Vereins für Socialpolitik 2017: Alternative Geld- und Finanzarchitekturen - Session: Taxation III, No. C19-V2.

Campolieti, Michele, Robert Hebdon, and Benjamin Dachis. 2014. "Collective Bargaining in the Canadian Public Sector: The Consequence of Restraint and Structural Change.” British Journal of Industrial Relations 54(1): 192-213.

Canadian Home Builders' Association. 2012. "Pulse Survey.” Winter.

——. 2013. "Pulse Survey." Winter.

——. 2014. "Pulse Survey." Winter.

Cao, Xinyu (Jason), Henry Liu, Xiaozheng (Sean) He, Zhiyi Xu, Yan (Arthur) Huang, Lee Munnich. 2012. "Benefit and Cost Analysis of the I-394 MnPASS Program.” Humphrey School of Public Affairs and Department of Civil Engineering, University of Minnesota. CTS 12-03. February.

Chaykowski, Richard P., and Robert S. Hickey. 2012. "Reform of the Conduct and Structure of Labour Relations in the Ontario Broader Public Service: Report to the Commission on the Reform of Ontario's Public Service."

Cheshire, Paul. 2017. "How to Capture Land Value Rises.” Planning Resource. February 10.

Cheshire, Paul, and Christian Hilber. 2008. "Office Space Supply Restrictions in Britain: The Political Economy of Market Revenge.” Economic Journal 118 (529): F185-F221.

Cheshire, Paul, Max Nathan, and Henry Overman. 2014. Urban Economics and Urban Policy. Cheltenham, U.K.; Northampton, MA: Edward Elgar. 
Cheshire, Paul, and Stephen Sheppard. 2002. "The Welfare Economics of Land Use Planning." Journal of Urban Economics 52 (2): 242-69.

Ciccone, Antonio, and Robert E. Hall. 1996. "Productivity and the Density of Economic Activity." American Economic Review 86 (1): 54-70.

Clarkson, Stephen. 1971. "Barriers to Entry of Parties into Toronto's Civic Politics: Towards a Theory of Party Penetration.” Canadian Journal of Political Science 4(2): 206-23.

Clayton, Frank. 2014. "A New Direction for Funding Growth-Related Water and Wastewater Infrastructure in the Greater Toronto Area and Hamilton." Centre for Urban Research and Land Development (CUR), Ryerson University, Toronto. November.

- - 2015. "Why There Is a Shortage of New Ground-Related Housing in the GTA." Centre for Urban Research and Land Development, Ryerson University Policy Commentary No. 4. June.

Cobban, Timothy W. 2017. "Bigger Is Better: Reducing the Cost of Local Administration by Increasing Jurisdiction Size in Ontario, Canada, 1995-2010.” Urban Affairs Review 1-39. July.

Combes, Pierre-Philippe, Gilles Duranton, Laurent Gobillon, and Sébastien Roux. 2010.

"Estimating Agglomeration Economies with History, Geology, and Worker Effects." In Edward L. Glaeser, ed., Agglomeration Economics. Chicago: University of Chicago Press.

Conduent. 2017. "Case Study: City of Los Angeles Department of Transportation Intelligent Parking Management for Downtown Los Angeles." Conduent Public Sector Public Transportation and Mobility.

Côté, Andre, and Michael Fenn. 2014. "Provincial-Municipal Relations in Ontario: Approach an Inflection Point.” Institute on Municipal Finance and Governance. Number 17.

Couture, Victor, Gilles Duranton, and Matthew A. Turner. (Forthcoming). "Speed." Review of Economics and Statistics.

CUPE. 2016. “Sector Profile: Municipal.” October 17. Available online at https://cupe.ca/ sector-profile-municipal

Dachis, Benjamin. 2010. Picking Up Savings: The Benefits of Competition in Municipal Waste Services. Commentary 308. Toronto: C.D. Howe Institute. September.

- - 2011. "Congestive Traffic Failure: The Case for High-Occupancy and Express Toll Lanes in Canadian Cities.” E-Brief 122. Toronto: C.D. Howe Institute. August.

- - 2012. Stuck in Place: The Effect of Land Transfer Taxes on Housing Transactions. Commentary 364. Toronto: C.D. Howe Institute. October.

- - 2013. Cars, Congestion and Costs: A New Approach to Evaluating Government Infrastructure Investment. Commentary 385. Toronto: C.D. Howe Institute. July.

——. 2014. Full Throttle: Reforming Canada's Aviation Policy. Commentary 398. Toronto: C.D. Howe Institute. January.

- - 2015a. "Tackling Traffic: The Economic Cost of Congestion in Metro Vancouver." E-Brief 206. Toronto: C.D. Howe Institute. March. 
- - 2015b. "Why tolling carpool lanes is the right move for Ontario." Globe and Mail. July 30.

——. 2016. "Getting More Buildings for Our Bucks: Canadian Infrastructure Policy in 2016."

E-Brief 225. Toronto: C.D. Howe Institute. January.

2017a. "Re-Heat Tolls Plan to Make HOT Lanes.” Intelligence Memo. Toronto: C.D. Howe Institute. March 1.

- - 2017b. New and Improved: How to Bring Institutional Investment into Public Infrastructure. Commentary 473. Toronto: C.D. Howe Institute.

- - 2018a. Death by 1,000 Cuts? Oil and Natural Gas Policy Competitiveness Scorecard. Commentary 501. Toronto: C.D. Howe Institute. February.

- - 2018b. "Hosing Homebuyers: Why Municipalities Should Not Pay for Water and Wastewater Infrastructure with Development Charges.” E-Brief 281. Toronto: C.D. Howe Institute. August.

Dachis, Benjamin, Gilles Duranton, and Matthew Turner. 2008. Sand in the Gears: Evaluating the Effects of Toronto's Land Transfer Tax. Commentary 277. Toronto: C.D. Howe Institute. December.

- - 2012. "The Effects of Land Transfer Taxes on Real Estate Markets: Evidence from a Natural Experiment in Toronto." Journal of Economic Geography 12(2): 327-54.

Dachis, Benjamin, and Robert Hebdon. 2010. The Laws of Unintended Consequences: The Effect of Labour Legislation on Strikes and Wages. Commentary 304. Toronto: C.D. Howe Institute. June.

Dachis, Benjamin, and Jacob Kim. 2018a. "Let's Get Off the Land Transfer Tax Roller Coaster." Intelligence Memo. Toronto: C.D. Howe Institute. March 19.

——. 2018b. "How Contracting Waste Services Can Improve Municipal Services.” Intelligence Memo. Toronto: C.D. Howe Institute. March 15.

Dachis, Benjamin, and William B.P. Robson. 2011. "Holding Canada’s Cities to Account: An Assessment of Municipal Fiscal Management.” Backgrounder 145. Toronto: C.D. Howe Institute. November.

- - 2014. Baffing Budgets: The Need for Clearer and More Comprehensive Financial Reporting by Canada's Municipalities. Commentary 397. Toronto: C.D. Howe Institute. January.

- - 2015. Building Better Budgets: Canada's Cities Should Clean Up Their Financial Reporting. Commentary 439. Toronto: C.D. Howe Institute. November.

Dachis, Benjamin, William B.P. Robson, and Jennifer Y. Tsao. 2016. Two Sets of Books at City Hall? Grading the Financial Reports of Canada's Cities. Commentary 460. Toronto: C.D. Howe Institute. November.

Dachis, Benjamin, William B.P. Robson, and Farah Omran. 2017. Fuzzy Finances: Grading the Financial Reports of Canada's Municipalities. Commentary 496. Toronto: C.D. Howe Institute. November. 
Dachis, Benjamin, Blake Shaffer, and Vincent Thivierge. 2017. All's Well That Ends Well: Addressing End-of-Life Liabilities for Oil and Gas Wells. Commentary 492. Toronto: C.D. Howe Institute. September.

Dachis, Benjamin, and Vincent Thivierge. 2018. Through the Roof: The High Cost of Barriers to Building New Housing in Canadian Municipalities. Commentary 513. Toronto: C.D. Howe Institute. May.

Dachis, Benjamin, and Jennifer Tsao. 2016a. "Get Rid of Jurassic Parking.” Intelligence Memo. Toronto: C.D. Howe Institute. July 28.

——. 2016b. "Toronto's Parking App Economy." Intelligence Memo. Toronto: C.D. Howe Institute. November 18.

Dafflon, Bernard. 2018. "Returning to the Golden Rule of Balanced Budgets: Institutional and Political Economy of Restricting Public Deficits and Debt." Institute on Municipal Finance and Governance. Number 39.

Dahlby, Bev. 2009. "Once on the Lips, Forever on the Hips: A Benefit-Cost Analysis of Fiscal Stimulus in OECD Countries.” Backgrounder 121. Toronto: C.D. Howe Institute. December.

Dahlby, Bev, and Brian Conger. 2015. "Taxation of Machinery and Equipment and Linear Property in Alberta." Canadian Tax Journal 63: 487-99.

Dahlby, Bev, and Ergete Ferede. 2016. "The Costliest Tax of All: Raising Revenue Through Corporate Tax Hikes Can Be Counter-Productive for the Provinces." University of Calgary, School of Public Policy, Research Paper 9 (11). March.

Dahlby, Bev, and Emily Jackson. 2015. "Striking the Right Balance: Federal Infrastructure Transfer Programs, 2002-2015.” University of Calgary, School of Public Policy, Research Paper 8 (35). November.

Dahlby, Bev, and Melville McMillan. 2014. "Do Local Governments Need Alternative Sources of Tax Revenue? An Assessment of the Options for Alberta Cities." University of Calgary, School of Public Policy, Research Paper 7 (26). September.

- - 2018. "An Assessment of Municipal Property Taxes and Land Transfer Taxes." Paper for the CTF-IMFG Conference, Funding the Canadian City, Toronto. February 6-7.

Dahlby, Bev, Michael Smart, and Benjamin Dachis. 2009. "New Housing and the Harmonized Sales Tax: Lessons from Ontario.” Backgrounder 119. Toronto: C.D. Howe Institute. October.

Davidoff, Thomas. 2016. "Governments need to act on housing affordability." Vancouver Sun. May 20. Available online at http://vancouversun.com/opinion/ opinion-governments-need-to-act-on-housing-affordability

——. 2017. "Zoning for dollars: Getting community amenity contributions out of the backroom." Vancouver Sun. June 19. Available online at http://vancouversun.com/opinion/op-ed/ opinion-zoning-for-dollars-getting-community-amenity-contributions-out-of-the-backroom

Davidoff, Ian, and Andrew Leigh. 2013. "How Do Stamp Duties Affect the Housing Market?" Economic Record 89: 396-410. 
Davis, Morris, and Jonathan Heathcote. 2007. "The Price and Quantity of Residential Land in the United States.” Journal of Monetary Economics 54 (8): 2595-620.

de la Roca, Jorge, and Diego Puga. 2012. "Learning by Working in Big Cities." CEPR Discussion Paper 9243. Center for Economic and Policy Research.

Dewees, Don. 2002. “Pricing Municipal Services: The Economics of User Fees.” Canadian Tax Journal 50 (2): 586-580.

Dewees, Don, Michael Trebilcock, Ian Freedman, and Brent Snell. 1993. "The Regulation of Solid Waste Management in Ontario: A Policy Perspective." University of Toronto Law School and Department of Economics. April.

Dijkgraaf, Elbert, and Raymond Gradus. 2007. "Collusion in the Dutch Waste Collection Market.” Local Government Studies 33 (4): 573-88.

Duong, Lynn, and David Amborski. 2017. "Modernizing Building Approvals in Ontario: Catching Up with Advanced Jurisdictions." Centre for Urban Research and Land Development (CUR), Ryerson University, Toronto. July 5.

Duranton, Gilles, and Hubert Jayet. 2011. "Is the Division of Labour Limited by the Extent of the Market? Evidence from French Cities." Journal of Urban Economics 69 (1): 56-71.

Duranton, Gilles, and Matthew A. Turner. 2011. "The Fundamental Law of Road Congestion: Evidence from US Cities.” American Economic Review 101 (6): 2616-52.

Ecofiscal Commisson. 2017. "Only the Pipes Should Be Hidden.” September.

Eliasson, Jonas, and Mattias Lundberg. 2012. "Do Cost-Benefit Analyses Influence Transport Investment Decisions? Experiences from the Swedish Transport Investment Plan 2010-21.” Transport Reviews 32 (1): 29-48.

Ellison, Glenn, and Edward L. Glaeser. 1997. "Geographic Concentration in U.S. Manufacturing Industries: A Dartboard Approach.” Journal of Political Economy 105(5): 889-927.

Evans-Cowley, Jennifer, Larry Lockwood, Ronald Rutherford, and Thomas Springer. 2009. "The Effect of Development Impact Fees on Housing Values.” Journal of Housing Research 18 (2): 173-93.

Evergreen. 2015. “Toronto Regional Housing Data Bank.” Spring. Available online at https:// www.evergreen.ca/downloads/pdfs/HousingActionLab/HAL DataBank L1.pdf

Fenn, Michael, and Harry Kitchen. 2016. "Bringing Sustainability to Ontario's Water Systems: A Quarter-Century of Progress, with Much Left to Do." An independent research study commissioned by the Ontario Sewer and Watermain Construction Association of Ontario.

Ferreira, Fernando. 2010. "You Can Take It with You: Proposition 13 Tax Benefits, Residential Mobility, and Willingness to Pay for Housing Amenities." Journal of Public Economics 94 (9-10): 661-73.

Fischel, William A. 2001. The Homevoter Hypothesis: How Home Values Influence Local Government Taxation, School Finance, and Land-Use Policies. Cambridge, MA: Harvard University Press. 
Flynn, Alexandra, and Zachary Spicer. 2017. "Re-imagining Community Councils in Canadian Local Government." Institute on Municipal Finance and Governance. Number 36.

Flyvbjerg, Bent, Nils Bruzelius, and Werner Rothengatter. 2003. Megaprojects and Risk: An Anatomy of Ambition. Cambridge, U.K.: Cambridge University Press.

Flyvbjerg, Bent, and Cass Sunstein. 2016. "The Principle of the Malevolent Hiding Hand; Or, the Planning Fallacy Writ Large.” Social Research 83 (4): 979-1004.

Found, Adam. 2012. "Economies of Scale in Fire and Police Services in Ontario." Institute on Municipal Finance and Governance. Number 12.

——. 2016. "Tapping the Land: Tax Increment Financing of Infrastructure." E-Brief 232.

Toronto: C.D. Howe Institute. March.

——. 2017. "Flying Below the Radar: The Harmful Impact of Ontario's Business Property Tax." E-Brief 266. Toronto: C.D. Howe Institute. November.

Found, Adam, and Peter Tomlinson. 2016. "Business Tax Burdens in Canada's Major Cities: The 2016 Report Card.” E-Brief 251. Toronto: C.D. Howe Institute. December.

——. 2017. "Business Tax Burdens in Canada's Major Cities: The 2017 Report Card.” E-Brief 269. Toronto: C.D. Howe Institute. December.

Found, Adam, Peter Tomlinson, and Benjamin Dachis. 2015. "Business Tax Burdens in Canada's Major Cities: The 2015 Report Card.” E-Brief 221. Toronto: C.D. Howe Institute. November.

Friendly, Abigail. 2017. "Land Value Capture and Social Benefits: Toronto and São Paulo Compared." Institute on Municipal Finance \& Governance 33.

Fyfe, Stephen, Mark Garner, and George Vegh. 2013. Mergers by Choice, Not Edict: Reforming Ontario's Electricity Distribution Policy. Commentary 376. Toronto: C.D. Howe Institute. March.

Gibbons, Stephen, and Stephen Machin. 2005. "Valuing Rail Access Using Transport Innovations." Journal of Urban Economics 57(1): 148-69.

Gibbons, Steve, Susana Mourato, and Guilherme Resende. 2011. The Amenity Value of English Nature: A Hedonic Price Approach. Spatial Economics Research Centre Discussion Papers, SERCDP0074. London School of Economics and Political Sciences, London, U.K.

Glaeser, Edward, Joshua Gottlieb, and Joseph Gyourko. 2010. "Can Cheap Credit Explain the Housing Boom?” NBER Working Paper 16230. July.

Glaeser, Edward, and Joseph Gyourko. 2017. “The Economic Implications of Housing Supply.” National Bureau of Economic Research Working Paper 23833.

Glaeser, Edward, Joseph Gyourko, and Albert Saiz. 2008. "Housing Supply and Housing Bubbles." Journal of Urban Economics 64: 198-217.

Glaeser, Edward, Joseph Gyourko, and Raven Saks. 2005. "Why Is Manhattan So Expensive? Regulation and the Rise in Housing Prices." Journal of Law and Economics 48 (2): 331-69. 
Glaeser, Edward, and Giacomo Ponzento. 2017. "The Political Economy of Transportation Investment.” NBER Working Paper. January.

Glaeser, Edward, and Bryce Ward. 2009. "The Causes and Consequences of Land Use Regulation: Evidence from Greater Boston.” Journal of Urban Economics 65 (3): 265-78.

Green, Kenneth, Josef Filipowicz, Steve Lafleur, and Ian Herzog. 2016. “The Impact of Land-Use Regulation on Housing Supply in Canada." Fraser Institute. July.

Grout, Cyrus A., William K. Jaeder, and Andrew J. Plantinga. 2011. "Land-Use Regulations and Property Values in Portland, Oregon: A Regression Discontinuity Design Approach.” Regional Science and Urban Economics 41(2): 98-107.

Gyourko, Joseph, and Raven Molloy. 2015. “Regulation and Housing Supply.” In Gilles Duranton, J. Vernon Henderson, and William Strange, eds., Handbook of Regional and Urban Economics 5: 1289-1337.

Hall, Jonathan. 2017. "On Rent Control, the Devil Is in the Details." Intelligence Memo. Toronto: C.D. Howe Institute. April 28.

2018. "Pareto Improvements from Lexus Lanes: The Effects of Pricing a Portion of the Lanes on Congested Highways." Journal of Public Economics 158: 113-25.

Hart, Oliver, and John Moore. 1988. "Incomplete Contracts and Renegotiation." Econometrica 56 (4): $755-85$.

HDR, Inc. 2015. TransLink Current and Projected Costs of Congestion in Metro Vancouver: Final Report. February.

Head, Allen, and Huw Lloyd-Ellis. 2016. "Has Canadian House Price Growth Been Excessive?" Canadian Journal of Economics 49 (4): 1367-1400.

Heamans, Elspeth. 2017. Tax, Order and Good Government: A New Political History of Canada, 1867-1917. Montreal \& Kingston: McGill-Queen's University Press.

Hebdon, Robert. 2006. "Contracting Public Services in New York State: Labour Effects.” Industrial Relations 61 (3): 513-31.

Hebdon, Robert, and Patrice Jalette. 2008. "The Restructuring of Municipal Services: A CanadaUnited States Comparison.” Environment and Planning C: Government and Policy 26: 144-58.

Hebdon, Robert, and Maurice Mazerolle. 2003. "Regulating Conflict in Public Sector Labour Relations." Industrial Relations 58 (4): 667-86.

Hebdon, Robert, and Robert Stern. 2003. “Do Public Sector Strike Bans Really Prevent Conflict?” Industrial Relations: 493-512. July.

Herkenhoff, Kyle F., Lee E. Ohanian, and Edward C. Prescott. 2017. "Tarnishing the Golden and Empire States: Land-Use Restrictions and the U.S. Economic Slowdown.” NBER Working Paper No. 23790. September. 
Hilber, Christian A.L., and Teemu Lyytikainen. 2012. "The Effect of the UK Stamp Duty Land Tax on Household Mobility." SERC Discussion Papers, SERCDP0115. Spatial Economics Research Centre (SERC), London School of Economics and Political Science, London, U.K.

Hilber, Christian, and Frederic Robert-Nicoud. 2013. "On the Origins of Land Use Regulations: Theory and Evidence from US Metro Areas." Journal of Urban Economics 75: 29-43.

Hilber, Christian, and Wouter Vermeulen. 2016. "The Impact of Supply Constraints on House Prices in England." Economic Journal 126 (591): 358-405.

Holmes, Thomas J. 1999. "Localization of Industry and Vertical Disintegration." Review of Economics and Statistics 81(2): 314-25.

Hsieh, Chang-Tai, and Enrico Moretti. 2015. "Housing Constraints and Spatial Misallocation.” NBER Working Paper No. 21154. May.

Iacobacci, Mario. 2017. "Business Cases for Major Public Infrastructure Projects in Canada." University of Calgary, School of Public Policy, Research Paper 10 (28). November.

Ihlanfeldt, Keith, and Timothy Shaughnessy. 2004. "An Empirical Investigation of the Effect of Impact Fees on Housing and Land Markets." Regional Science and Urban Economics 34 (6): 639-61.

İmrohoroğlu, Ayşe, Kyle Matoba, and Şelale Tüzel. 2018. "Proposition 13: An Equilibrium Analysis.” American Economic Journal: Macroeconomics 10 (2): 24-51.

Iseki, Hiroyuki. 2010. "Effects of Contracting on Cost Efficiency in US Fixed-Route Bus Transit Service.” Transportation Research Part A 44: 457-72.

Jacobs, Jane. 1969. The Economy of Cities. Toronto: Vintage Books.

Jaffe, Eric. 2013. “Road Fees Don’t Hurt the Poor as Much as You Might Think.” Citylab. June 17.

Jalette, Patrice, and Peter Warrian. 2002. "Contracting-Out Provisions in Canadian Collective Agreements: A Moving Target.” Workplace Gazette 5 (1): 64-76.

Jones, Allison. 2017. "Ontario denies Toronto tolls, boosts gas tax funds for municipalities." Canadian Press. January 27.

Kelleher, Maria, Janet Robins, and John Dixie. 2005. Taking Out the Trash: How to Allocate the Costs Fairly. Commentary 213. Toronto: C.D. Howe Institute. July.

Kendall, Ross, and Peter Tulip. 2018. “The Effect of Zoning on Housing Prices.” Reserve Bank of Australia, Research Discussion Paper RDP 2018-03. March.

Kitchen, Harry. 1992. "Urban Transit Provision in Ontario: A Public/Private Sector Cost Comparison.” Public Finance Quarterly 20 (1): 114-28.

- - 2006. A State of Disrepair: How to Fix the Financing of Municipal Infrastructure in Canada. Commentary 241. Toronto: C.D. Howe Institute. December.

Kitchen, Harry, and Enid Slack. 1993. "Business Property Taxation.” Government and Competitiveness Project Discussion Paper 9324. Kingston, ON: Queen's University, School of Policy Studies. 
——. 2003. "Special Study: New Finance Options for Municipal Governments." Canadian Tax Journal 51(6): 2215-75.

——. 2016. "More Tax Sources for Canada's Largest Cities: Why, What, and How?" IMFG Papers on Municipal Finance and Governance 27.

Knoll, Katharina, Moritz Schularick, and Thomas Steger. 2017. "No Price Like Home: Global House Prices, 1870-2012.” American Economic Review 107 (2): 331-53.

Koop, Royce, and John Kramer, 2016. "Wards, At-Large Systems and the Focus of Representation in Canadian Cities." Canadian Journal of Political Science 49 (3): 433-48.

Kopczuk, Wojciech, and David Munroe. 2015. "Mansion Tax: The Effect of Transfer Taxes on the Residential Real Estate Market.” American Economic Journal: Economic Policy 7(2): 214-57.

Kronick, Jeremy. 2017a. Spendthrifts and Savers: Are Canadians Acting Like They Are "House Poor" or "House Rich"? Commentary 482. Toronto: C.D. Howe Institute. June.

——. 2017b. "Why Rent Control Is Doomed to Fail." Intelligence Memo. Toronto: C.D. Howe Institute May 1.

Langbein, Laura I., Philip Crewson, and Charles Niel Brasher. 1996. "Rethinking Ward and At-Large Elections in Cities: Total Spending, the Number of Locations of Selected City Services, and Policy Types." Public Choice 88 (3/4): 275-93.

Laurin, Alexandre. 2018. "Two-Parent Families with Children: How Effective Tax Rates Affect Work Decisions.” E-Brief. Toronto: C.D. Howe Institute. January.

Lindsey, Robin. 2007. Congestion Relief: Assessing the Case for Road Tolls in Canada. Commentary 248. Toronto: C.D. Howe Institute. May.

- - 2008. "Prospects for Urban Road Pricing in Canada." Brookings-Wharton Papers on Urban Affairs. Available at http://www.jstor.org/stable/25609552

—_. 2009. "Road Pricing 101 and Public Acceptance Issues." Presentation at Transport Futures 2009: Road Pricing \& Public Acceptance. November 12-13.

Malone Given Parsons. 2017. "Getting the Growth Plan Right.” Available online at http://www. mgp.ca/wp-content/uploads/2017/04/Getting-the-Growth-Plan-Right-March-2017.pdf

Malpezzi, Stephen, and Susan M. Wachter. 2005. "The Role of Speculation in Real Estate Cycles." Journal of Real Estate Literature 13 (2): 143-64.

Manulife. 2016. 2015 Annual Report. May 5. Available online at http://www.manulife.com/public/ files/202/1/mfc_annualreport2015.pdf

Marques, Rui Cuhna, and Kristof De Witte. 2011. "Is Big Better? On Scale and Scope Economies in the Portuguese Water Sector.” Economic Modelling 28: 1009-16.

Marshall. Alfred. 1890. Principles of Economics. London: Macmillan and Co.

Mathur, Shishir. 2007. “Do Impact Fees Raise the Price of Existing Housing?” Housing Policy

Debate 18 (4): 635-59. 
——. 2013. "Do All Impact Fees Affect Housing Prices the Same?" Journal of Planning Education and Research 33 (4): 442.

Mathur, Shishir, Paul Waddell, and Hilda Blanco. 2004. "The Effect of Impact Fees on the Price of New Single-Family Housing." Urban Studies 41 (7): 1303-12.

Mayer, Christopher, and C. Tsuriel Somerville. 2000. "Land Use Regulation and New Construction." Regional Science and Urban Economics 30: 639-62.

MCAP. 2017. "Fall 2017 Breakfast Seminar Presentation.” December 6. Available online at https:// www.mcap.com/fall-2017-presentation

McDavid, James. 2000. "Alternative Service Delivery in Canadian Local Governments: The Costs of Producing Solid Waste Management Services.” Canadian Journal of Regional Science 23 (1): 157-74.

- - 2001. "Solid-Waste Contracting-Out, Competition, and Bidding Practices Among Canadian Local Governments.” Canadian Public Administration 44 (March): 1-25.

Meloche, Jean-Phillipe, and Francois Vaillancourt. 2017. "Financing Urban Infrastructure in Quebec: Use of Fees in the Water and Transportation Sectors." In Richard Bird and Enid Slack, eds. Financing Infrastructure: Who Should Pay? Montreal \& Kingston: McGill-Queen's University Press.

Mévellec, Anne, and Maon Tremblay. 2013. "Les partis politiques municipaux: La "westminsterisation» des villes du Québec ?” Recherches sociographiques 54(2): 325-47.

Metrolinx. 2008a. "Cost of Road Congestion in the Greater Toronto and Hamilton Area: Impact and Cost-Benefit Analysis of the Metrolinx Draft Regional Transportation Plan." Final Report. December 1.

- - 2008b. "Backgrounder: Modelling Methodology and Results for the Regional Transportation Plan.” December.

Mintz, Jack M., and Tom Roberts. 2006. Running on Empty: A Proposal to Improve City Finances. Commentary 226. Toronto: C.D. Howe Institute. February.

Mobility Pricing Independent Commission. 2018. "Metro Vancouver Mobility Pricing Study Full Report on the Findings and Recommendations for an Effective, Farsighted, and Fair Mobility Pricing Policy." May.

Moore, Aaron. 2013. “Trading Density for Benefits: Toronto and Vancouver Compared.” Institute on Municipal Finance \& Governance 13.

——. 2017. "The Potential Consequences of Municipal Electoral Reform.” Institute on Municipal Finance and Governance. Perspectives Number 20.

——. 2018. "Buildings with Benefits: The Defect of Density Bonusing." E-Brief. Toronto: C.D. Howe Institute April.

Moretti, Enrico. 2012. The Nerw Geography of Jobs. Boston: First Mariner Books. 
Nicosia, Nancy. 2001. "Competitive Contracting in the Mass Transit Industry: Causes and Consequences.” Berkeley, University of California, Working Paper. November.

OFGEM. 2013. “The GB Electricity Distribution Network.” June 18.

Ontario. 2015. “Budget 2015: Chapter II: Ontario’s Economic Outlook and Fiscal Plan.” April 23.

Ontario. 2017. "Growth Plan for the Greater Golden Horseshoe.” May. Available online at http:// placestogrow.ca/index.php?option=com content\&task=view\&id=430\&Itemid=14

——. "Budget 2018: Chapter II: Growing the Economy and Creating Good Jobs." March 28.

Overman, Henry, and Diego Puga. 2010. "Labour Pooling as a Source of Agglomeration: An

Empirical Investigation.” In Edward L. Glaeser, ed., Agglomeration Economics. Chicago: University of Chicago Press.

Pasolli, Kelly, Thomas McManus, Molly Doan, Max Palamar, and Karen Myers. 2016. "National Housing Collaborative Affordability Options Research Paper.” Social Research and Demonstration Corporation. October.

Persson, Torsten, Gérard Roland, and Guido Tabellini. 2007. "Electoral Rules and Government Spending in Parliamentary Democracies." Quarterly Journal of Political Science 2: 155-88.

Persson, Torsten, and Guido Tabellini. 2004. "Constitutional Rules and Fiscal Policy Outcomes." American Economic Review 94 (1): 25-45.

Piketty, Thomas. 2014. Capital in the Twenty-First Century. Cambridge, MA: Harvard University Press.

Pomeroy, Steve, Marion Steele, Joshua Hoy, and John Stapleton. 2008. "A Housing Benefit for Ontario: One Housing Solution for a Poverty Reduction Strategy." November.

Rawls, John. 1971. A Theory of Justice. Cambridge, MA: Harvard University Press.

Realpac. 2012. “2012 Canada-wide Development Process Survey Report.”

——. 2013. "2013 Canada-Wide Development Process Survey Report.”

ReNew Canada. 2016. “Top 100: Canada’s Biggest Infrastructure Projects.” Actual media. Available online at http://top100projects. ca/2012filters/?yr=2016

Robins, Steven. 2017a. "Surge Capacity: Selling City-Owned Electricity Distributors to Meet Broader Municipal Infrastructure Needs.” E-Brief 257. Toronto: C.D. Howe Institute. April.

- - 2017b. Banking on Infrastructure: How the Canada Infrastructure Bank Can Build Infrastructure Better for Canadians. Commentary 483. Toronto: C.D. Howe Institute. June.

——. 2017c. "Adding More Juice: How Private Investors Can Improve the Performance of Provincial Power Assets." E-Brief 260. Toronto: C.D. Howe Institute. June.

Robson, William B.P., and Alexandre Laurin. 2016. Worse Than It Looks: The True Burden and Risks of Federal Employee Pension Plans. Commentary 449. Toronto: C.D. Howe Institute. May. 
- - 2018. Retiring Employees, Unretired Debt: The Surprising Hidden Cost of Federal Employee Pensions. Commentary 514. Toronto: C.D. Howe Institute. May.

Robson, William B.P., and Farah Omran. 2018. Blown Budgets: Canada's Senior Governments Need Better Fiscal Controls. Commentary 512. Toronto: C.D. Howe Institute. May.

Rognlie, Matthew. 2015. "Deciphering the Fall and Rise in the Net Capital Share: Accumulation or Scarcity?” Brookings Papers on Economic Activity. Spring.

Rosenthal, Stuart S., and William C. Strange. 2003. "Evidence on the Nature and Sources of Agglomeration Economies." Handbook of Urban and Regional Economics 4. August 24.

Saiz, Albert. 2010. "The Geographic Determinants of Housing Supply." Quarterly Journal of Economics 125 (3): 1253-96.

Savage, Ian. 1993. “Deregulation and Privatization of Britain's Local Bus Industry.” Journal of Regulatory Economics 5:143-58.

Sayers, Anthony, and Jack Lucas. 2017. "Policy Responsiveness and Political Accountability in City Politics.” University of Calgary, School of Public Policy, Research Paper 10 (4). March.

Segal, Geoffrey, Ade Ifelayo, and Chandra Pesheck. 2004. "Exposing the Myths and Realities of Competitive Sourcing." Policy Brief 31. Los Angeles: Reason Foundation. August.

Severen, Christopher, and Andrew J. Plantinga. 2017. "Land-Use Regulations, Property Values, and Rents: Decomposing the Effects of the California Coastal Act." FRB Philadelphia Working Paper 17-33. Available online at https://www.philadelphiafed.org/-/media/research-and-data/publications/working-papers/2017/wp17-33.pdf

SF Park. N.d. "Pilot Project Evaluation. The SFMTA's Evaluation of the Benefits of the SF Park Pilot Project.”

Shoup, Donald. 2011. The High Cost of Free Parking. Routledge.

Siddiqui, Faiz. 2015. "You've heard about surge pricing. Get ready for surge-priced parking." Washington Post. November 7.

Siemiatycki, Matti. 2015. "Cost Overruns on Infrastructure Projects: Patterns, Causes, and Cures.” Institute on Municipal Finance and Governance, Perspectives 11.

Slack, Enid. 2011. “The Property Tax - In Theory and Practice.” IMFG Papers on Municipal Finance and Governance 2.

Slack, Enid, and Richard Bird. 2013. “Merging Municipalities: Is Bigger Better?” Institute on Municipal Finance and Governance 14.

——. 2015. "How to Reform the Property Tax: Lessons from Around the World." IMFG Papers on Municipal Finance and Governance 21.

Slemrod, Joel, Caroline Weber, and Hui Shan. 2017. "The Behavioral Response to Housing Transfer Taxes: Evidence from a Notched Change in D.C. policy." Journal of Urban Economics 100(C): 137-53. 
Southwick, Lawrence. 1997. "Local Government Spending and At-Large versus District Representation; Do Wards Result in More 'Pork'?” Economics and Politics 9 (2): 173-202.

Spicer, Zachary, and Adam Found. 2016. Thinking Regionally: How to Improve Service Delivery in Canada's Cities. Commentary 458. Toronto: C.D. Howe Institute. October.

Taylor, Zack. 2016. “Good Governance at the Local Level: Meaning and Measurement.” Institute on Municipal Finance and Governance 26.

Toronto. 2018a. "Long-Term Financial Plan: The City of Toronto's Roadmap to Financial Sustainability.” Spring.

——. 2018b. "Revised Free-Floating Car-Share Pilot and Interim Policy.” January 24.

——. 2018c. "Revised Free-Floating Car-Share Pilot and Interim Policy." April 24.

- - 2018d. "To Amend City of Toronto Municipal Code Chapter 415, Development of Land, by Re-enacting Article I, Development Charges." BY-LAW 515-2018. April 25-27.

Toronto Region Board of Trade, written by Patrick Gill, Brian Kelcey, and Jeff Parker. 2018. "Agenda for Growth: Transit Uploading Policy."

Transport Canada. 2006a. The Cost of Urban Congestion in Canada. Ottawa: Transport Canada, Environmental Affairs. March 22.

- - 2006b. Costs of Non-Recurrent Congestion in Canada Final Report. Transport Canada Economic Analysis TP 14664E. December 11.

Tuckey, Brian. 2017. "As province overhauls OMB, local zoning bylaws need updating." Toronto Star. May 27. Available online at https://www.thestar.com/life/homes/2017/05/27/as-province-overhauls-omb-local-zoning-bylaws-need-updating.html

Turner, Matthew A., Andrew Haughwout, and Wilbert van der Klaauw. 2014. "Land Use Regulation and Welfare." Econometrica 82 (4): 1341-1403.

United Kingdom Department for Transport. 2005. "Transport, Wider Economic Benefits, and Impact on GDP.” Discussion Paper. July.

Vancity. 2018. "Changing Gears: Exploring the Car-Sharing Culture Shift in Metro Vancouver.” January.

Wallis, Ian, and David Lupton. 2013. “The Costs of Congestion Reappraised.” New Zealand Transport Agency Research Report 489. February.

Walls, Margaret. 2003. "How Local Governments Contract with Private Firms: Economic Theory and Evidence on Solid Waste and Recycling Contracts." Discussion Paper 03-62. Washington, D.C.: Resources for the Future. November.

Wilkins, Margarita. 2017a. "Stock of Apartment Rental Units in Four Major Metropolitan Areas." University of Calgary, School of Public Policy, Social Policy Trends. May.

——. 2017b. "Housing Affordability for Families with Low Incomes Across Canada." University of Calgary, School of Public Policy, Social Policy Trends. June. 
Winnipeg. 2018. “Impact Fee.” February 15. Available online at http://winnipeg.ca/PPD/ ImpactFee/

Wood, Tricia. 2017. "The biggest transit need in southern Ontario is local, not regional." Torontoist. December 15.

Worthington, Andrew, and Helen Higgs. 2014. "Economies of Scale and Scope in Australian Urban Water Utilities.” Utilities Policy 31: 52-62.

Zon, Noah, and Hadley Nelles. 2017. "Should the National Housing Strategy Include a Housing Benefit?” Toronto: Maytree Foundation. February. 


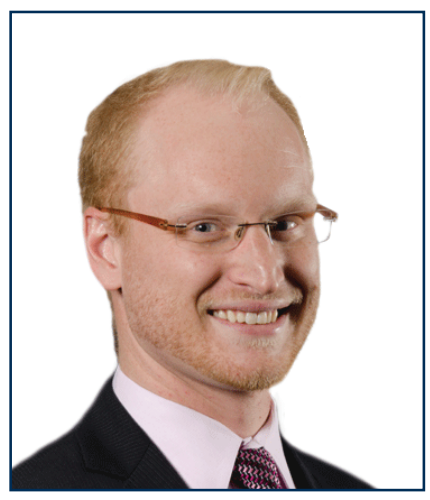

\section{ABOUT THE AUTHOR:}

Benjamin Dachis is former Associate Director, Research, of the C.D. Howe Institute. He holds a BA (Hons) and an $\mathrm{MA}$ in Economics from the University of Toronto as well as an MSc from the London School of Economics. Mr. Dachis started with the C.D. Howe Institute in 2006 as a Research Fellow and, following experience with a major U.S. think tank, returned to the C.D. Howe Institute as a Policy Analyst in January of 2008. He has written extensively on municipal finance, transportation, tax, energy, environmental and labour policy. Mr. Dachis wrote this book while on sabbatical from the C.D. Howe Institute in the spring of 2018. 


\section{About the C.D. Howe Institute}

The C.D. Howe Institute is a registered charity, and an independent not-for-profit research institute whose mission is to raise living standards by fostering economically sound public policies. Widely considered to be Canada's most influential think tank, the Institute is a trusted source of essential policy intelligence, distinguished by research that is nonpartisan, evidence-based and subject to definitive expert review.

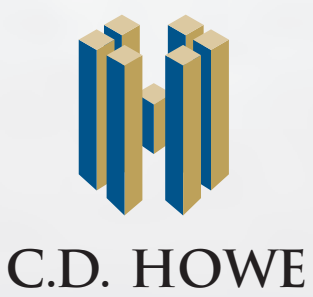

INSTITUTE 